Prepared in cooperation with the Osage Nation

\title{
Assessment of Water Availability in the Osage Nation Using an Integrated Hydrologic-Flow Model
}
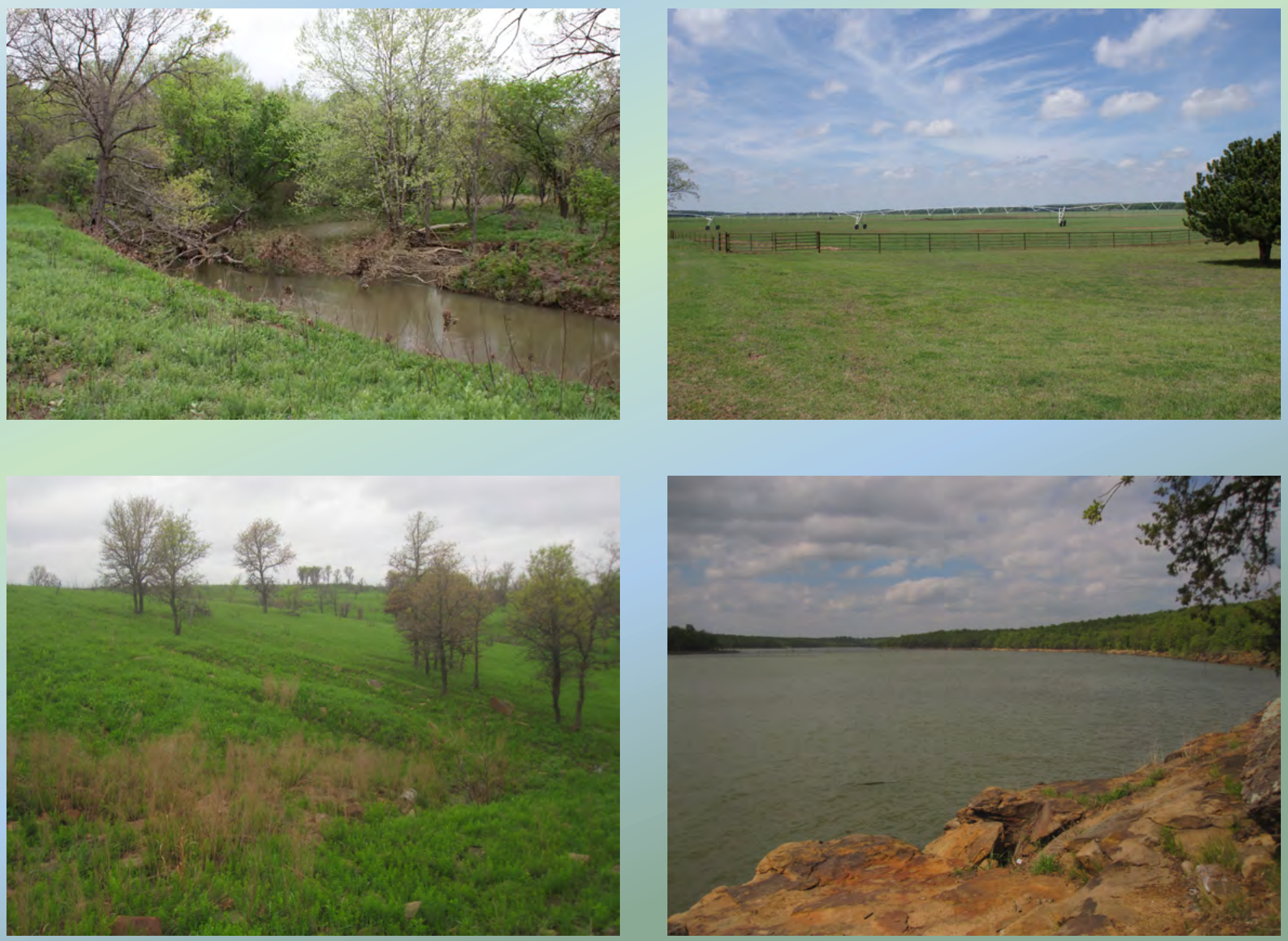

Scientific Investigations Report 2020-5141

U.S. Department of the Interior

U.S. Geological Survey 
Cover. Clockwise from top left: Photograph showing Sand Creek, taken north of Pawhuska, Oklahoma, on April 19, 2017, by Jonathan P. Traylor, U.S. Geological Survey (USGS) hydrologist. Photograph showing irrigation pivots, taken west of Ralston, Okla., on April 19, 2017, by Jonathan P. Traylor, USGS hydrologist. Photograph showing Skiatook Lake, taken near Hominy, Okla., on April 19, 2017, by Joseph A. Hevesi, USGS research hydrologist. Photograph showing grassland, taken north of Pawhuska, Okla., on April 19, 2017, by Jonathan P. Traylor, USGS hydrologist. 


\section{Assessment of Water Availability in the Osage Nation Using an Integrated Hydrologic-Flow Model}

By Jonathan P. Traylor, Shana L. Mashburn, Randall T. Hanson, and

Steven M. Peterson

Prepared in cooperation with the Osage Nation

Scientific Investigations Report 2020-5141 


\section{U.S. Geological Survey, Reston, Virginia: 2021}

For more information on the USGS - the Federal source for science about the Earth, its natural and living resources, natural hazards, and the environment-visit https://www.usgs.gov/ or call 1-888-ASK-USGS (1-888-275-8747).

For an overview of USGS information products, including maps, imagery, and publications, visit https://store.usgs.gov.

Any use of trade, firm, or product names is for descriptive purposes only and does not imply endorsement by the U.S. Government.

Although this information product, for the most part, is in the public domain, it also may contain copyrighted materials as noted in the text. Permission to reproduce copyrighted items must be secured from the copyright owner.

Suggested citation:

Traylor, J.P., Mashburn, S.L., Hanson, R.T., and Peterson, S.M., 2021, Assessment of water availability in the Osage Nation using an integrated hydrologic-flow model: U.S. Geological Survey Scientific Investigations Report 2020-5141, 96 p., https://doi.org/10.3133/sir20205141.

Associated data for this publication:

Traylor, J.P., and Peterson, S.M., 2021, MODFLOW-One Water Hydrologic Model integrated hydrologic-flow model used to evaluate water availability in the Osage Nation: U.S. Geological Survey data release, https://doi.org/10.5066/ P910K02C.

U.S. Geological Survey, 2016, USGS water data for the Nation: U.S. Geological Survey National Water Information System database, https://doi.org/10.5066/F7P55KJN.

ISSN 2328-0328 (online) 


\section{Acknowledgments}

The authors express their gratitude to Jann Hayman, Craig Walker, Erika Capps, and Cameron Chesbro from the Osage Nation Environmental and Natural Resources Department for their coordination and cooperation throughout the duration of this study that started in 2013. The authors recognize Jon Sanford from the Oklahoma Water Resources Board (OWRB) for providing the water-use dataset.

The authors also recognize additional U.S. Geological Survey (USGS) scientists that contributed to the study: Joseph Hevesi, Scott Boyce, and Wesley Henson from the USGS California Water Science Center; Moussa Guira, Ben Dietsch, and Brent Hall from the USGS Nebraska Water Science Center; Mark Hudson and Michael Pantea from the USGS Geosciences and Environmental Change Science Center in Denver, Colorado; David Smith from the USGS Crustal Geophysics and Geochemistry Science Center in Denver, Colo.; and William Andrews, S. Jerrod Smith, Jason Masoner, Kyle Rennell, Nicole Paizis, John Ellis, Scott Strong, Justin White, Emily Moyer, and Carol Becker from the USGS Oklahoma Water Science Center. This project would not have been possible without the USGS Cooperative Matching Funds Program and the USGS Research Drilling Team. 



\section{Contents}

Acknowledgments ……...................................................................................................................

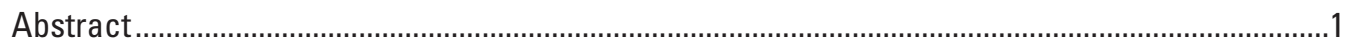

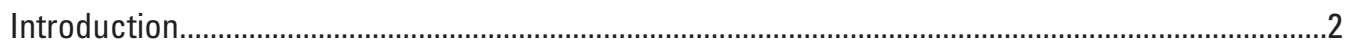

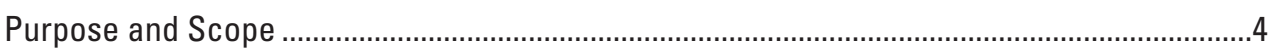

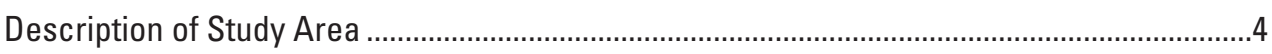

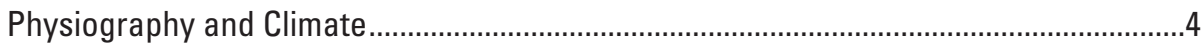

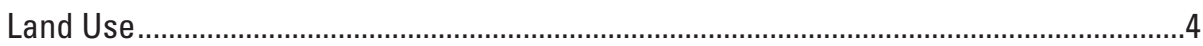

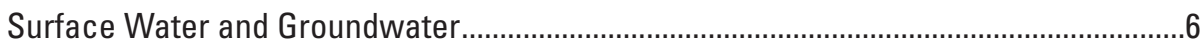

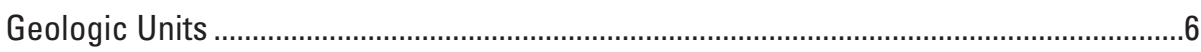

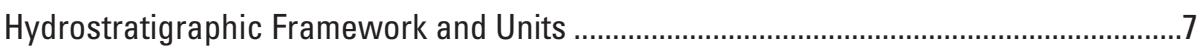

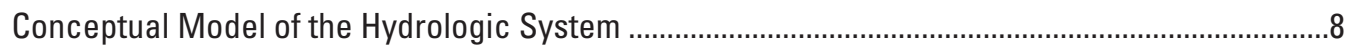

Components of the Hydrologic System ......................................................................................

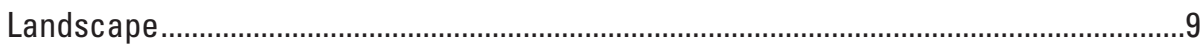

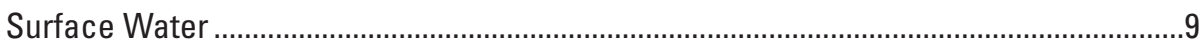

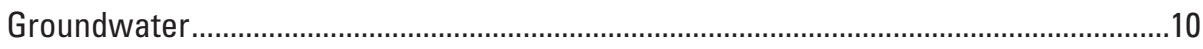

Aquifer Properties ............................................................................................11

Fresh/Marginal Groundwater and Saline Groundwater Interface ..........................13

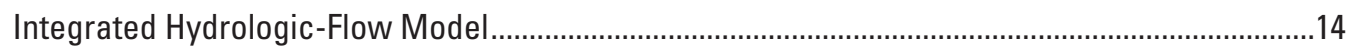

Integrated Hydrologic-Flow Model Construction and Discretization ...................................14

Spatial Discretization and Layering ......................................................................

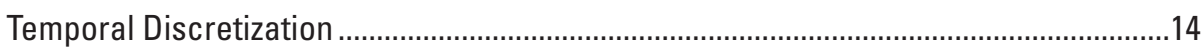

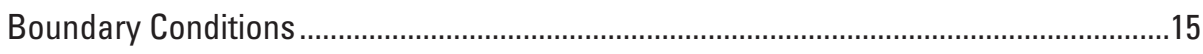

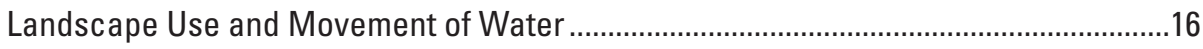

Water-Balance Subregions............................................................................17

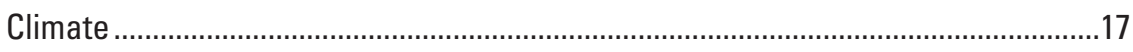

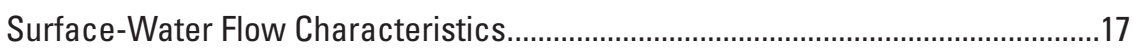

Simulated Land Use....................................................................................... 19

Crop-Type Characteristics...............................................................................19

Fractions of Transpiration and Evaporation from Irrigation and Precipitation.......19

Sources of Groundwater Supply for Crops ......................................................19

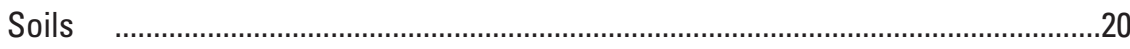

Groundwater Inflows, Outflows, and Changes in Storage ...........................................21

Integrated Hydrologic Model Calibration Approach ..........................................................21

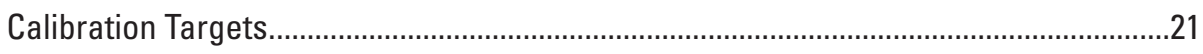

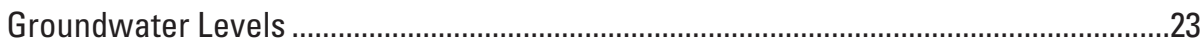

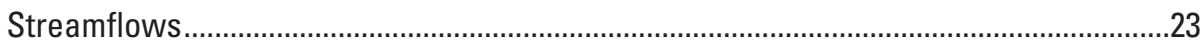

PEST Calibration Parameters .........................................................................................25

Horizontal Hydraulic Conductivity Estimated at Pilot Points ....................................25

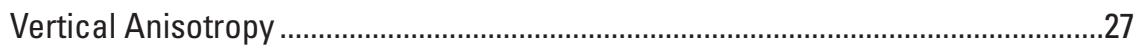

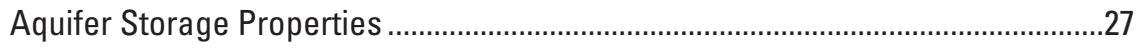

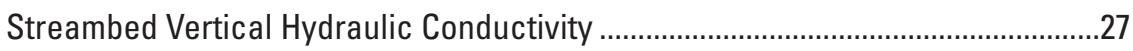

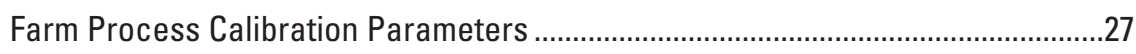

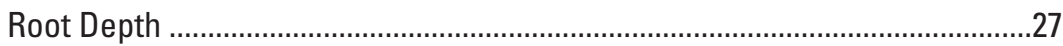


Fraction of Inefficient Losses to Surface Water from Precipitation ...............27

Fraction of Inefficient Losses to Surface Water from Irrigation......................28

Scale Factors for Potential Evapotranspiration................................................28

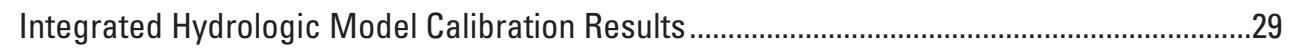

Comparison of Calibration Targets to Simulated Equivalents ...........................................29

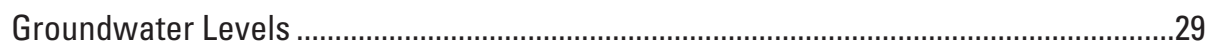

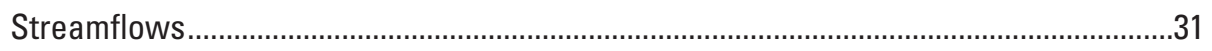

Calibration Parameter Results............................................................................................33

Horizontal Hydraulic Conductivity Interpolated from Pilot Points .............................33

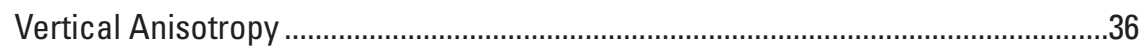

Streambed Vertical Hydraulic Conductivity .........................................................36

Farm Process Calibrated Parameter Values .............................................................36

Root Depth .............................................................................................36

Fraction of Inefficient Losses to Surface Water from Precipitation ...............36

Fraction of Inefficient Losses to Surface Water from Irrigation......................37

Scale Factors for Potential Evapotranspiration...............................................37

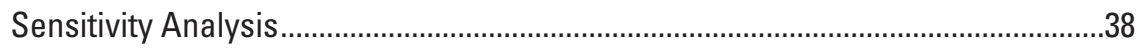

Water Availability Analysis and Simulated Water Budgets..............................................................40

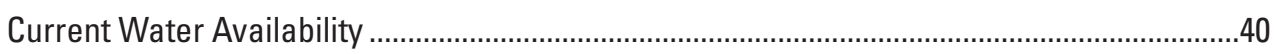

Landscape Water Budget......................................................................................... 40

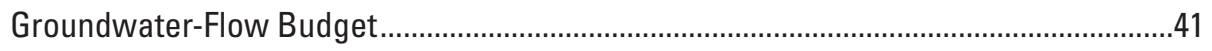

Supergroup Landscape and Groundwater-Flow Budgets ............................................49

Climate-Based Landscape Water Budgets ...................................................................50

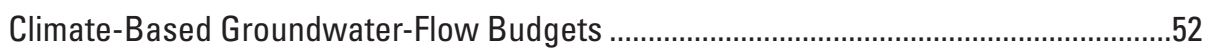

Fresh/Marginal Groundwater and Saline Groundwater ..............................................52

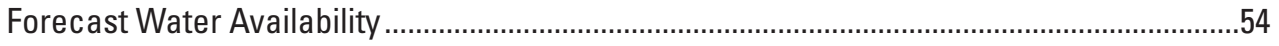

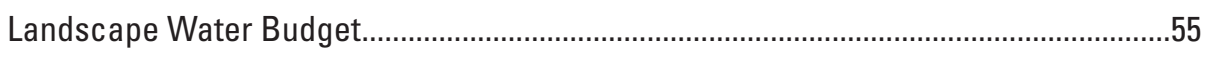

Groundwater-Flow Budget..................................................................................5

Supergroup Landscape and Groundwater-Flow Budgets .............................................65

Forecasted Fresh/Marginal Groundwater and Saline Groundwater ...............................67

Assumptions and Limitations ...............................................................................................

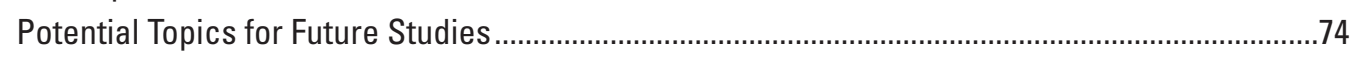

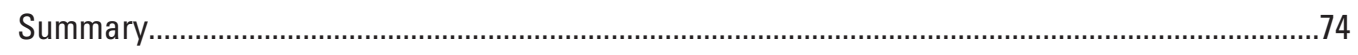

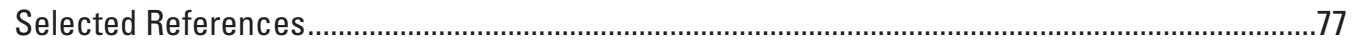

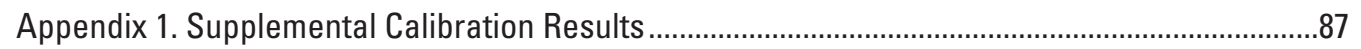




\section{Figures}

1. Map showing study area showing Osage Nation extent, integrated hydrologic model extent, precipitation-runoff model extent, streamgages, the location of Cole cross-section borehole logs, and the altitudes of the base of marginal groundwater.....3

2. Map showing land-use extents in $\mathbf{2 0 1 4}$ for $\mathbf{1 0}$ major land-use classes within the Osage Nation Integrated Hydrologic Model active boundary.....

3. Graph showing mean monthly potential evapotranspiration within the Osage Nation Integrated Hydrologic Model active boundary from January 1950 to September 2014

4. Map showing side view of the active cells for each of the Osage Nation Integrated Hydrologic Model layers and their corresponding hydrostratigraphic layers

5. Map showing total active and inactive model cells, boundary conditions, stream cells simulated with the Streamflow Routing Package, production wells, and irrigation wells in the Osage Nation Integrated Hydrologic Model across all layers.....12

6. Graph showing groundwater-level hydrograph of U.S. Geological Survey observation wells 364210097025401,363058096440101 , and 363727096143201

7. Schematic representation of components simulated by the Farm Process Package in the MODFLOW One-Water Hydrologic Model for the Osage Nation Integrated Hydrologic Model

8. Map showing supergroups for the Osage Nation Integrated Hydrologic Model............18

9. Map showing the three soil types used in the Osage Nation Integrated Hydrologic Model.

10. Map showing wells and streamgages used for calibration targets by the Osage Nation Integrated Hydrologic Model from January 1950 to September 2014

11. Map showing locations of pilot points by model layer for the Osage Nation Integrated Hydrologic Model active area/boundary

12. Photograph showing Sand Creek in Osage Hills State Park, Oklahoma, showing a bedrock streambed

13. Graph showing measured versus simulated water-level altitudes and their coefficient of determination $\left(R^{2}\right)$ values for the measdevw/ groundwater-level observation group used in the Osage Nation Integrated Hydrologic Model, from January 1950 to September 2014

14. Map showing simulated groundwater-level altitude contours for the final stress period of the calibrated Osage Nation Integrated Hydrologic Model, dry forecast, average forecast, and wet forecast

15. Graphs showing linear regression plots of measured/estimated versus simulated streamflows and their coefficient of determination $\left(R^{2}\right)$ values for streamflow observation groups.

16. Graph showing comparison of initial and calibrated mean monthly potential evapotranspiration depths for the Osage Nation Integrated Hydrologic Model from January 1950 to September 2014

17. Graph showing sensitivity of computed observations to changes in Parameter Estimation (PEST) calibration parameters groups by PEST observation groups for the Osage Nation Integrated Hydrologic Model

18. Graph showing annual fluxes of the simulated landscape water budget components for the Osage Nation Integrated Hydrologic Model from January 1950 to September 2014 
19. Graph showing linear regression of simulated annual evapotranspiration from precipitation and precipitation for the Osage Nation Integrated Hydrologic Model from January 1950 to September 2014

20. Graph showing monthly fluxes of the simulated landscape water budget components, from January 1950 to September 2014, of the Osage Nation Integrated Hydrologic Model.

21. Graph showing linear regression of simulated monthly evapotranspiration from precipitation and precipitation for the Osage Nation Integrated Hydrologic Model from January 1950 to September 2014

22. Graph showing simulated annual net groundwater-flow budget component fluxes for the Osage Nation Integrated Hydrologic Model from January 1950 to September 2014

23. Graphs showing linear regression of precipitation correlation to simulated net groundwater storage and net farm net recharge for the Osage Nation Integrated Hydrologic Model from January 1950 to September 2014

24. Graph showing simulated mean monthly net groundwater fluxes for the Osage Nation Integrated Hydrologic Model from January 1950 to September 2014

25. Graph showing simulated mean monthly net stream leakage for the Arkansas River below Kaw Lake supergroup for the Osage Nation Integrated Hydrologic Model from January 1950 to September 2014

26. Map showing the simulated saturated thickness of fresh/marginal groundwater across the Osage Nation Integrated Hydrologic Model active area at the end of the 1950-2014 period.

27. Graphs showing simulated mean monthly net landscape water budget fluxes for the Osage Nation Integrated Hydrologic Model

28. Graphs showing simulated mean monthly groundwater-flow budget fluxes for the Osage Nation Integrated Hydrologic Model.

29. Graph showing simulated mean annual groundwater-flow budget fluxes for the wet forecast of the Osage Nation Integrated Hydrologic Model...

30. Maps showing simulated saturated thickness of fresh/marginal groundwater for the Osage Nation Integrated Hydrologic Model.

\section{Tables}

1. Streamgages in the study area, period of streamflow record, average annual streamflow, and average annual base flow...

2. Stratigraphic column showing geologic ages; geologic units; hydrostratigraphic units; three-dimensional geology model layer names; Osage Nation Integrated Hydrologic Model layer name, number; and minimum, mean, and maximum thickness

3. Well counts by geologic or hydrostratigraphic unit within the Osage Nation Integrated Hydrologic Model extent.....

4. Streamflow and groundwater-level calibration target counts and data description

and source by Parameter Estimation software observation group

5. The 1950-2014 period Osage Nation Integrated Hydrologic Model calibration results, by layer, including groundwater-level altitude statistics, horizontal hydraulic conductivity, anisotropy, and streambed vertical hydraulic conductivity.......30 
6. Observation count by Parameter Estimation software observation group, calibrated mean streamflow residuals and groundwater-level residuals by observation group, and contribution to the initial and final objective function for each observation group for the 1950-2014 period Osage Nation Integrated Hydrologic Model.

7. Calibrated mean streamflow residuals and calibrated mean streamflow residuals as a percentage of measured streamflow for each measured and estimated streamgage location for the 1950-2014 period Osage Nation Integrated Hydrologic Model.

8. Calibration results for Farm Process parameters, by land use, in the 1950-2014 period Osage Nation Integrated Hydrologic Model

9. Abbreviations and definitions of the simulated landscape water budget and groundwater-flow budget terms for the Osage Nation Integrated Hydrologic Model ...41

10. Simulated mean annual January 1950 to September 2014 net fluxes and mean annual January 1950 to September 2014 percentages of precipitation for the landscape water budget components for each supergroup and total active model area for the Osage Nation Integrated Hydrologic Model

11. Simulated groundwater-flow budget average annual fluxes by supergroup for the Osage Nation Integrated Hydrologic Model from January 1950 to September 2014......48

12. Simulated mean annual landscape water budget component fluxes for all, dry, average, and wet years for the Osage Nation Integrated Hydrologic Model from January 1950 to September 2014

13. Simulated mean annual net groundwater-flow component fluxes for all, dry, average, and wet years for the Osage Nation Integrated Hydrologic Model from January 1950 to September 2014

14. Percentage of deciduous forest and pasture land use; simulated minimum, average, and maximum saturated thickness of fresh/marginal groundwater; and average saturated thickness of saline groundwater by supergroup for the Osage Nation Integrated Hydrologic Model from January 1950 to September 2014

15. Summary of the simulated mean annual dry, average, and wet forecasts for the active model area and for each supergroup landscape water budget component and fluxes and percentage change from dry forecast for the Osage Nation Integrated Hydrologic Model.

16. Summary of the simulated mean annual dry, average, and wet forecasts for the active model area and for each supergroup landscape water budget component in percentages of precipitation for the Osage Nation Integrated Hydrologic Model.

17. Simulated mean annual groundwater-flow budget fluxes for the active model area and by supergroup for the dry, average, and wet forecasts of the Osage Nation Integrated Hydrologic Model

18. Summary of simulated saturated thickness of the fresh/marginal and saline groundwater for each forecast by supergroup of the Osage Nation Integrated Hydrologic Model 


\section{Conversion Factors}

U.S. customary units to International System of Units

\begin{tabular}{|c|c|c|}
\hline Multiply & By & To obtain \\
\hline \multicolumn{3}{|c|}{ Length } \\
\hline inch (in.) & 39.3701 & meter $(\mathrm{m})$ \\
\hline foot $(\mathrm{ft})$ & 0.3048 & meter $(\mathrm{m})$ \\
\hline mile (mi) & 1.609 & kilometer (km) \\
\hline \multicolumn{3}{|c|}{ Area } \\
\hline acre & 4,047 & square meter $\left(\mathrm{m}^{2}\right)$ \\
\hline acre & 0.004047 & square kilometer $\left(\mathrm{km}^{2}\right)$ \\
\hline square mile $\left(\mathrm{mi}^{2}\right)$ & 2.590 & square kilometer $\left(\mathrm{km}^{2}\right)$ \\
\hline \multicolumn{3}{|c|}{ Flow rate } \\
\hline cubic foot per second $\left(\mathrm{ft}^{3} / \mathrm{s}\right)$ & 0.02832 & cubic meter per second $\left(\mathrm{m}^{3} / \mathrm{s}\right)$ \\
\hline cubic foot per day $\left(\mathrm{ft}^{3} / \mathrm{d}\right)$ & 0.02832 & cubic meter per day $\left(\mathrm{m}^{3} / \mathrm{d}\right)$ \\
\hline gallon per minute (gal/min) & 0.06309 & liter per second (L/s) \\
\hline inch per year (in/yr) & 25.4 & millimeter per year $(\mathrm{mm} / \mathrm{yr})$ \\
\hline mile per hour $(\mathrm{mi} / \mathrm{h})$ & 1.609 & kilometer per hour $(\mathrm{km} / \mathrm{h})$ \\
\hline \multicolumn{3}{|c|}{ Hydraulic conductivity } \\
\hline foot per day $(\mathrm{ft} / \mathrm{d})$ & 0.3048 & meter per day $(\mathrm{m} / \mathrm{d})$ \\
\hline \multicolumn{3}{|c|}{ Hydraulic gradient } \\
\hline foot per mile ( $\mathrm{ft} / \mathrm{mi})$ & 0.1894 & meter per kilometer $(\mathrm{m} / \mathrm{km})$ \\
\hline \multicolumn{3}{|c|}{ Transmissivity } \\
\hline foot squared per day $\left(\mathrm{ft}^{2} / \mathrm{d}\right)$ & 0.09290 & meter squared per day $\left(\mathrm{m}^{2} / \mathrm{d}\right)$ \\
\hline
\end{tabular}

Temperature in degrees Fahrenheit $\left({ }^{\circ} \mathrm{F}\right)$ may be converted to degrees Celsius $\left({ }^{\circ} \mathrm{C}\right)$ as follows:

$$
{ }^{\circ} \mathrm{C}=\left({ }^{\circ} \mathrm{F}-32\right) / 1.8 \text {. }
$$

\section{Datum}

Vertical coordinate information is referenced to the North American Vertical Datum of 1988 (NAVD 88).

Horizontal coordinate information is referenced to the North American Datum of 1983 (NAD 83). Altitude, as used in this report, refers to distance above the vertical datum.

\section{Supplemental Information}

Concentrations of chemical constituents in water are given in either milligrams per liter (mg/L) or micrograms per liter $(\mu \mathrm{g} / \mathrm{L})$. 


\section{Abbreviations}

$\Phi$

aqprops

AVG

climprops

CWD

DEM

devflux

devfluxenr

devfluxprms

DP

DRY

Egw

Ei

estdevwl

ET

ETgw

ETp

farmprops

FIESWI

FIESWP

flowchng

flowchngprms

FMP

objective function

one of five PEST calibration parameter groups: aquifer properties

average forecast

one of five PEST calibration parameter groups: climate properties

crop water demand

digital elevation model

one of nine PEST observation groups: measured streamflows from USGS streamgages (see table 4 for further information)

one of nine PEST observation groups: measured streamflows from the Osage Nation Environmental and Natural Resources Department (see table 4 for further information)

one of nine PEST observation groups: simulated streamflows extracted from the PRMS model (see table 4 for further information)

one of ten landscape water budget terms: outflows from deep percolation past the root zone that becomes groundwater recharge (see table 9 for further information)

dry forecast

one of ten landscape water budget terms: outflows from evaporation of groundwater across the landscape (see table 9 for further information)

one of ten landscape water budget terms: outflows from evaporation of irrigation water across the landscape (see table 9 for further information)

one of nine PEST observation groups: estimated groundwater levels (see table 4 for further information)

evapotranspiration

one of two secondary landscape water budget terms: the sum of outflows from evaporation of groundwater across the landscape and outflows of transpiration of groundwater across the landscape (see table 9 for further information)

one of two secondary landscape water budget terms: the sum of outflows from evaporation of precipitation and outflows of transpiration of precipitation (see table 9 for further information)

one of five PEST calibration parameter groups

fraction of inefficient losses to surface water from irrigation

fraction of inefficient losses to surface water from precipitation

one of nine PEST observation groups: streamflow changes from the USGS streamgages (see table 4 for further information)

one of nine PEST observation groups: streamflow changes from the simulated PRMS model streamflows (see table 4 for further information)

Farm Process [Package] 


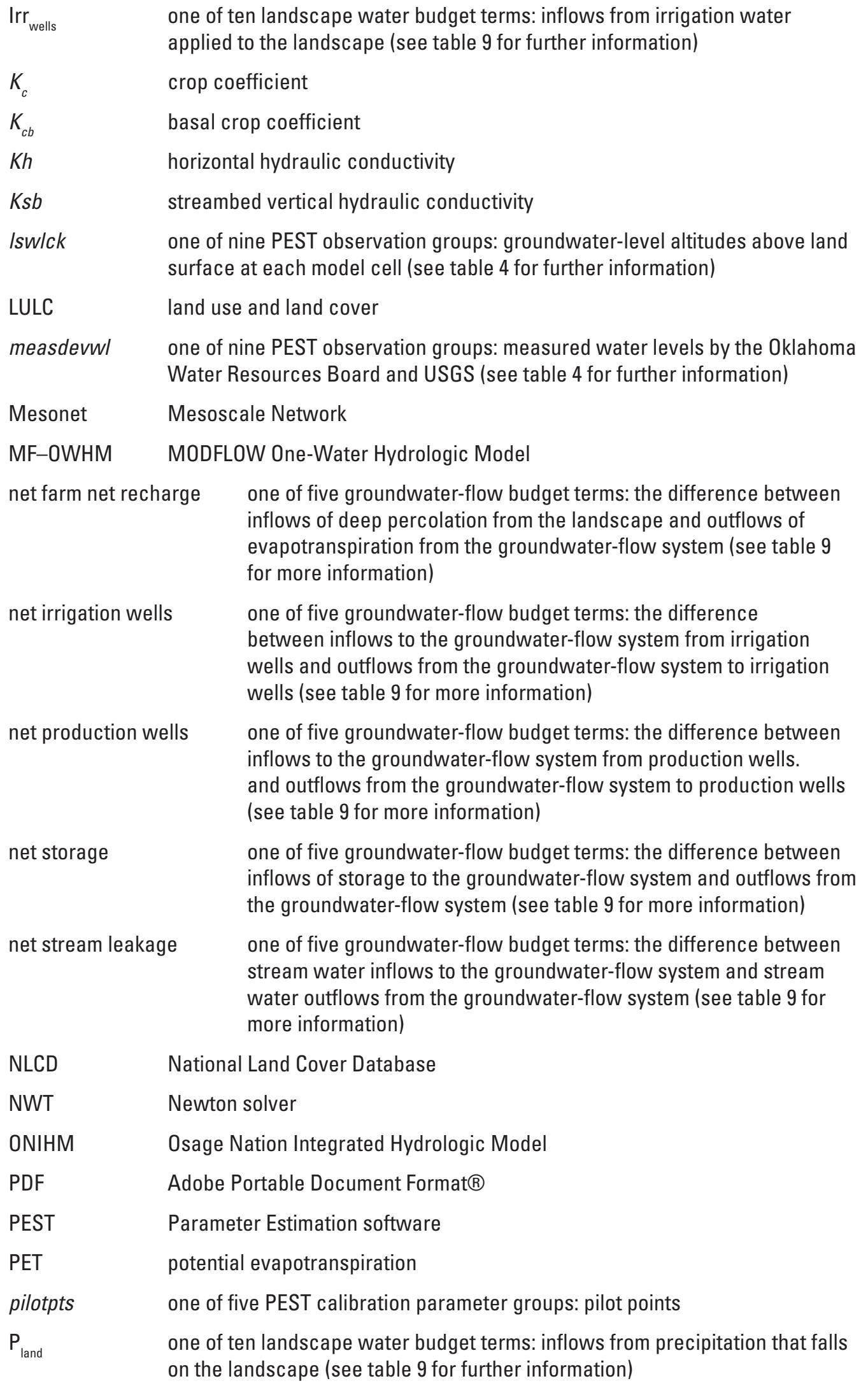




\begin{tabular}{|c|c|}
\hline PRMS & Precipitation Runoff Modeling System \\
\hline$R^{2}$ & coefficient of determination \\
\hline RO & $\begin{array}{l}\text { one of ten landscape water budget terms: outflows from runoff of } \\
\text { precipitation and irrigation water applied to the landscape (see table } 9 \text { for } \\
\text { further information) }\end{array}$ \\
\hline SFR & Streamflow Routing [Package] \\
\hline sfrprops & one of five PEST calibration parameter groups: stream properties \\
\hline$S_{s}$ & specific storage \\
\hline SWI & Salt Water Intrusion [Package] \\
\hline$S_{y}$ & specific yield \\
\hline syndevwl & $\begin{array}{l}\text { one of nine PEST observation groups: measured water levels from a } \\
\text { groundwater synoptic survey in November and December } 2014 \text { (see table } 4 \\
\text { for further information) }\end{array}$ \\
\hline Tgw & $\begin{array}{l}\text { one of ten landscape water budget terms: outflows from transpiration of } \\
\text { groundwater across the landscape (see table } 9 \text { for further information) }\end{array}$ \\
\hline $\mathrm{Ti}$ & $\begin{array}{l}\text { one of ten landscape water budget terms: outflows from transpiration of } \\
\text { irrigation water across the landscape (see table } 9 \text { for further information) }\end{array}$ \\
\hline Tp & $\begin{array}{l}\text { one of ten landscape water budget terms: outflows from transpiration of } \\
\text { precipitation across the landscape (see table } 9 \text { for further information) }\end{array}$ \\
\hline USGS & U.S. Geological Survey \\
\hline UZF & Unsaturated Zone Flow [Package] \\
\hline WBS & water-balance subregion \\
\hline WET & wet forecast \\
\hline
\end{tabular}





\title{
Assessment of Water Availability in the Osage Nation Using an Integrated Hydrologic-Flow Model
}

\author{
By Jonathan P. Traylor, Shana L. Mashburn, Randall T. Hanson, and Steven M. Peterson
}

\section{Abstract}

The Osage Nation of northeastern Oklahoma, conterminous with Osage County, covers about 2,900 square miles. The area is primarily rural with 62 percent of the land being native prairie grass, and much of the area is used for cattle ranching and extraction of petroleum and natural gas. Protection of water rights are important to the Osage Nation because of its reliance on cattle ranching and the potential for impairment of water quality by petroleum extraction. Additionally, the potential for future population increases, demands for water from neighboring areas such as the Tulsa metropolitan area, and expansion of petroleum and natural-gas extraction on water resources of this area further the need for the Osage Nation to better understand its water availability. Therefore, the U.S. Geological Survey, in cooperation with the Osage Nation, completed a hydrologic investigation to assess the status and availability of surface-water and groundwater resources in the Osage Nation.

A transient integrated hydrologic-flow model was constructed using the U.S. Geological Survey fully integrated hydrologic-flow model called the MODFLOW One-Water Hydrologic Model. The integrated hydrologic-flow model, called the Osage Nation Integrated Hydrologic Model (ONIHM), was constructed and uses an orthogonal grid of 276 rows and 289 columns, and each grid cell measures 1,312.34 feet (ft; 400 meters) per side, with eight variably thick vertical layers that represented the alluvial and bedrock aquifers within the study area, including the alluvial aquifer, the Vamoosa-Ada aquifer, and the minor Pennsylvanian bedrock aquifers, and the confining units. Landscape and groundwater-flow processes were simulated for two periods: (1) the 1950-2014 period from January 1950 through September 2014 and (2) the forecast period from October 2014 through December 2099. The 1950-2014 period ONIHM simulated past conditions using measured or estimated inputs, and the forecast-period ONIHM simulated three separate potential forecast conditions under constant dry, average, or wet climate conditions using calibrated input values from the 1950-2014 period ONIHM.

The 1950-2014 period ONIHM was calibrated by linking the Parameter Estimation software (PEST) with the MODFLOW One-Water Hydrologic Model. PEST uses statistical parameter estimation techniques to identify the best set of parameter values to minimize the difference between measured or estimated calibration targets and their simulated equivalent values (residuals). Tikhonov regularization and singular-value decomposition-assist features of PEST were used during the calibration process. The 1950-2014 period ONIHM was calibrated to 713 measured groundwater levels at 195 wells; 95,636 estimated monthly mean groundwater levels at 124 wells; 5,307 measured streamflows at 13 streamgages; and 8,679 simulated mean monthly streamflows at 10 streamgages extracted from a surface-water model by adjusting 231 parameters. The estimated groundwater-level observations and streamflows were included as observations to improve the spatial and temporal density of observation targets during calibration. The best set of parameter values obtained during the calibration process of the 1950-2014 model was then used as the input parameter values for the forecast model simulations. A comparison of the calibration targets to their corresponding simulated values indicated that the model adequately reproduced streamflows and groundwater levels for some streamgages and wells and underestimated streamflows and groundwater levels at other locations. Measured and simulated streamflows correlated adequately with a coefficient of determination of 0.938 , as did water levels with a coefficient of determination of 0.795 . The 1950-2014 period ONIHM underestimated certain groundwater levels and streamflows, but generally measured or estimated calibration targets correlated well with simulated equivalents, which indicated that the model can adequately simulate the response of the hydrologic system to stresses in the 1950-2014 and forecast periods.

In the 1950-2014 period ONIHM, the calibrated mean horizontal hydraulic conductivity for layer 1 alluvial aquifer was 30.7 feet per day, and the seven lower layers had a calibrated mean horizontal hydraulic conductivity of less than 3.3 feet per day. The mean calibrated groundwater-level residual was $16.6 \mathrm{ft}$, and the mean calibrated streamflow residual of the Arkansas River at Ralston, Oklahoma, streamgage (U.S. Geological Survey station 07152500) was within 6 percent (373 cubic feet per second) of mean measured streamflow for the 1950-2014 period ONIHM.

The ONIHM simulated landscape fluxes of precipitation; groundwater applied by irrigation wells; evapotranspiration from precipitation, groundwater, and irrigation; runoff from 
precipitation; and deep percolation from precipitation. The largest loss of water from the landscape was evapotranspiration from precipitation with a calibrated mean annual outflow of 32 inches (in.): mean annual precipitation was about 36 in. Calibrated mean annual runoff and deep percolation (recharge to the water table) rates were 4.7 inches per year (in/yr) and $0.70 \mathrm{in} / \mathrm{yr}$, respectively, for the 1950-2014 period ONIHM.

The calibrated 1950-2014 period ONIHM groundwater fluxes included net farm net recharge (calculated as the difference between the inflow of recharge to the water table and the outflow of evapotranspiration from the water table such that negative values indicate that evapotranspiration from the water table was greater than deep percolation [recharge to the water table] and vice versa). Net farm net recharge was the largest flux from the groundwater system with a mean annual net outflow of 153.4 cubic feet per second. Stream leakage was the largest flux to the groundwater system with a mean annual net inflow of 152.5 cubic feet per second, indicating that, on average, the groundwater/surface-water interaction was a "losing" system where stream water leaked into the subsurface and recharged the water table. Simulated monthly trends demonstrated that net stream leakage was the largest inflow to the groundwater-flow system for 10 of the 12 months; for the other 2 months (January and March), farm net recharge (January) and net storage (March) were the largest inflow to the groundwater-flow system.

A saline groundwater interface map was created for the study and compared to the water levels from the final stress period of the 1950-2014 model to identify the presence of fresh/marginal groundwater throughout the study area. Fresh/ marginal groundwater was characterized as groundwater with less than 1,500 milligrams per liter of total dissolved solids. Fresh/marginal groundwater thickness ranged from 0 to $438.2 \mathrm{ft}$ within the study area. The thickest regions of fresh/ marginal groundwater were in the eastern part of the study area near Sand Creek, Bird Creek, and Hominy Creek and in the Arkansas River alluvial aquifer in the region downstream from the Arkansas River at Ralston, Okla.

Like the 1950-2014 model, forecast model results for the landscape indicated that transpiration from precipitation was the largest flux out of the landscape for all three forecasts, constituting 77,73 , and 58 percent of precipitation for the dry, average, and wet forecasts, respectively. The dry and average forecast landscape fluxes demonstrated similar trends and magnitudes, whereas the wet forecast landscape fluxes indicated the largest changes compared to the average forecast fluxes. Most notably, runoff increased from a mean of 1.1 and $1.6 \mathrm{in} / \mathrm{yr}$ for the dry and average forecasts, respectively, to $10 \mathrm{in} / \mathrm{yr}$ for the wet forecast. Similar changes occurred for the other wet forecast landscape fluxes.

The calibrated 1950-2014 period ONIHM simulated three forecasts to assess the effects of potential climatic changes on the hydrologic system from October 2014 to December 2099. The three forecasts simulated theoretical dry, average, and wet conditions using precipitation and potential evapotranspiration datasets from selected years in the calibrated 1950-2014 period ONIHM. Annual precipitation amounts were $26.89,35.47$, and 50.73 in. for the dry, average, and wet forecasts, respectively. Groundwater-flow component forecast results indicated that stream leakage is always a net inflow to the groundwater-flow system for dry, average, and wet conditions, meaning the study area stream network is always predominantly a "losing" regime where stream water infiltrates into the underlying aquifer. Storage was only a net outflow from the groundwater-flow system and indicated a replenishment to groundwater storage that resulted in an increase in groundwater levels only during the wet forecast. Further, these gains in groundwater storage for the wet forecast occurred only during February through June.

Mean fresh/marginal groundwater saturated thicknesses were 125 and $126 \mathrm{ft}$ for the dry and average forecast conditions, respectively, and wet forecast average thickness was $145 \mathrm{ft}$ and ranged from 0 to $443 \mathrm{ft}$. The spatial extents of fresh/marginal groundwater at the end of the dry, average, and wet forecast model periods (December 2099) did not change substantially from the end of the 1950-2014 model period (September 2014).

\section{Introduction}

The Osage Nation is in northeastern Oklahoma and is conterminous with Osage County (fig. 1). Freshwater resources in the Osage Nation include water flowing in the Arkansas River, Hominy Creek, Bird Creek, Salt Creek, and other small tributaries; water stored in Kaw and Skiatook Lakes; and groundwater contained in unconsolidated alluvial aquifers and bedrock aquifers. Fresh groundwater is underlain by marginal and saline groundwater in aquifers underlying the Osage Nation (marginal defined herein as dissolved solids concentrations greater than 1,000 milligrams per liter [mg/L] and less than $1,500 \mathrm{mg} / \mathrm{L}$ ). The area is primarily rural, and much of the area is used for cattle ranching and extraction of petroleum and natural gas. Because of the Osage Nation's reliance on cattle ranching and the potential for impairment of water quality by petroleum extraction, protecting their water rights is important to the Osage Nation (Andrews and Smith, 2014).

Water rights in Tribal lands, such as those of the Osage Nation, are considered "Federal reserved water rights," which supersede State and local water rights but have limits (J.J. Lawler, Oklahoma State University, written commun., 1990; Helton, 1998). Under the Winters doctrine, based on the U.S. Supreme Court decision in Winters versus United States of 1908 and subsequent case law, the intent of the Federal government when reserving land for an Indian reservation was to reserve an adequate supply of water to fulfill the purpose of the reservation. For reservations such as the Osage Nation, the purpose of the reservation was for Tribal members to live pastoral lives, which implies use of water not only for domestic purposes and livestock but also for irrigation (J.J. Lawler, 


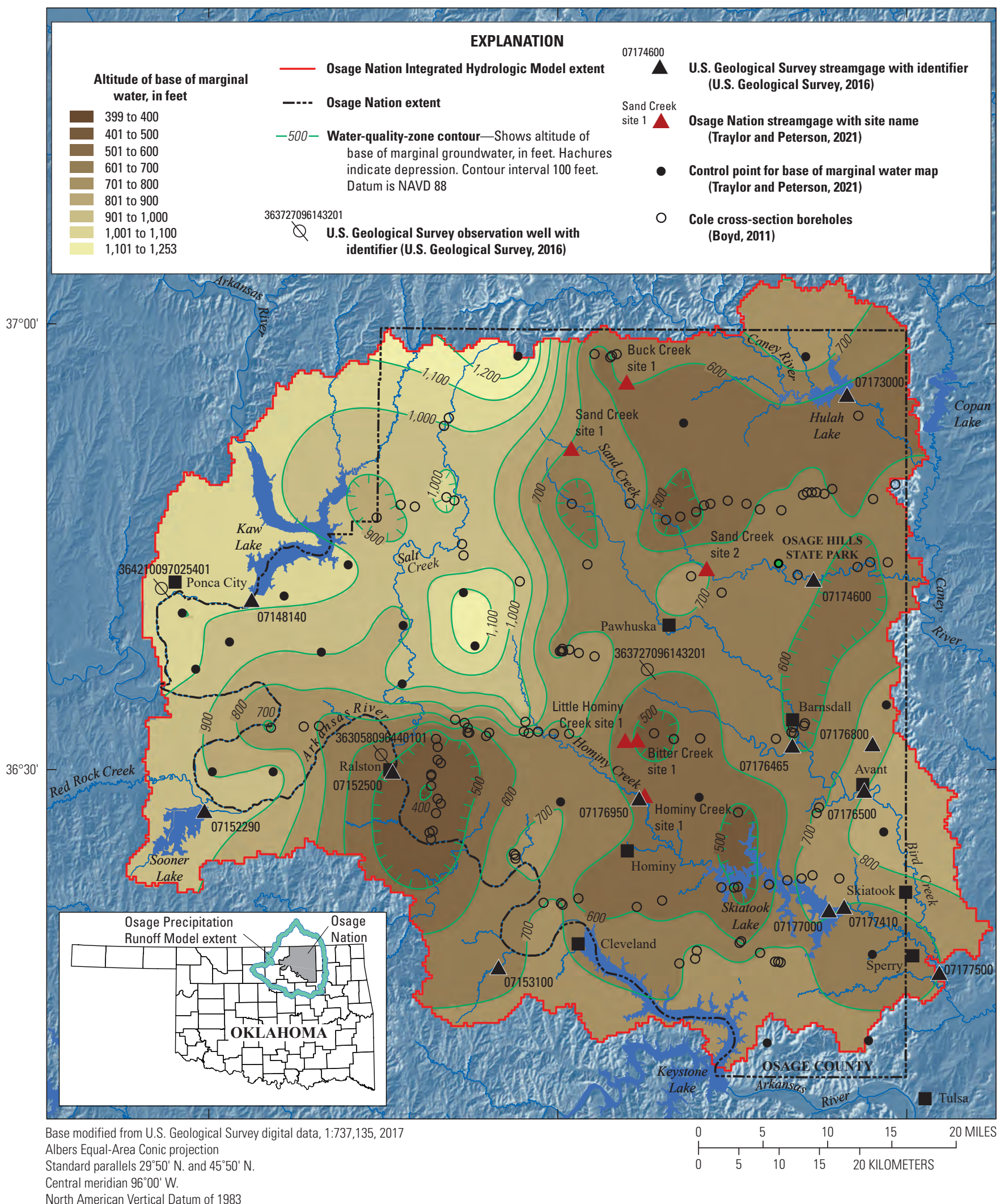

Figure 1. Study area showing Osage Nation extent, integrated hydrologic model extent, precipitation-runoff model extent, streamgages, the location of Cole cross-section borehole logs, and the altitudes of the base of marginal groundwater. 
Assessment of Water Availability in the Osage Nation Using an Integrated Hydrologic-Flow Model

Oklahoma State University, written commun., 1990). Such Federal reserved water rights are not limited to uses foreseen when a reservation was first established and must be enough to make the land and resources productive for its residents. Those unforeseen water rights are broader than those established for reserved water rights of other types of Federal reservations (Cohen, 1982).

Although Tribes in Oklahoma have water rights that supersede those of the State because of the Supremacy Clause (U.S. Const., art. IV, § 3) and establishment of Tribal nations before the State of Oklahoma, to effectively manage the dual system of water rights in Oklahoma, Tribal water rights claims need to be quantified (Helton, 1998). For the Osage Nation, because of the potential increased water use in this area in response to future population increases within the Osage Nation, demands for water from neighboring areas such as the Tulsa metropolitan area (fig. 1), and the expansion of petroleum and natural-gas extraction, the U.S. Geological Survey (USGS), in cooperation with the Osage Nation, completed a hydrologic investigation. This hydrologic investigation included the construction of an integrated hydrologic-flow model to provide data and information on hydrologic processes and to assess the potential fresh groundwater availability with respect to future water resources development plans in the Osage Nation.

\section{Purpose and Scope}

The purpose of this report is to summarize a hydrologic investigation of the water resources and analysis of water availability in the Osage Nation. A conceptual model was developed to quantify inflows, outflows, and storage and to identify the processes and fluxes by which these flows and storage occur in the Osage Nation. An integrated hydrologicflow model was constructed to simulate the conceptual model and to readily summarize the availability of water resources in the Osage Nation. The scope of the report includes results of the landscape and groundwater availability from the integrated hydrologic-flow models, the occurrence of fresh/marginal groundwater, and saline groundwater resources for the areas of interest to the Osage Nation. Landscape and groundwater-flow processes were simulated for two periods: (1) the 1950-2014 period from January 1950 through September 2014 and (2) the forecast period from October 2014 through December 2099.

\section{Description of Study Area}

The study area for this report was focused around the Osage Nation (fig. 1) in northeastern Oklahoma; the model domain encompassed the Osage Nation and its adjacent watersheds and covers an area of about 2,900 square miles (fig. 1). The area is sparsely populated with about 21 residents per square mile (U.S. Census Bureau, 2013). The Osage Nation area is characterized by gently rolling uplands with locally sharp cuestas formed by resistant sandstone and limestone ledges (Abbott and Tortorelli, 2002).

\section{Physiography and Climate}

The study area lies in the Osage Plains physiographic section of the larger Central Lowland province, which in turn, is part of the larger Interior Plains physiographic division (Andrews and Smith, 2014). This region is characterized by presence of tallgrass prairie that grades to woodland in the east and into shorter mixed-grass prairie to the west (Fenneman and Johnson, 1946; Andrews and Smith, 2014). The highest topographic elevations are in the north-central region of the study area near Salt Creek, and the lowest topographic elevations are in the southeastern region between Hominy Creek and Keystone Lake (fig. 1).

The study area is in the humid continental (warm summer) climate zone of the zone classification system (Köppen, 1936), which is typified by large seasonal temperature differences with warm to hot (and humid) summers and cold winters. Precipitation in this climate zone is usually well distributed throughout the year with a few local storm events. Daily climate data from 213 climate stations were summarized into daily, monthly, and annual summaries by Hevesi and others (2020) for the study area for 1910-2014. Mean annual precipitation in the study area was about 36 inches per year (in/yr; Oklahoma Climatological Survey, 2013). The cumulative departure from the mean precipitation reveals drier than normal conditions from 1950 to 1984 and wetter than normal conditions from 1984 to 2010 (Oklahoma Climatological Survey, 2013; Hevesi and others, 2020). The greatest amount of annual precipitation typically falls in the eastern part of the study area (about $40 \mathrm{in} / \mathrm{yr}$ ), and the least amount of annual precipitation (less than $30 \mathrm{in} / \mathrm{yr}$ ) typically falls in the western part of the study area (Oklahoma Climatological Survey, 2013). Average monthly precipitation is greatest during May and June (4 to 5 inches [in.] per month) and lowest during January and February (less than 2 in. per month; Andrews and Smith, 2014). Average annual snowfall is typically less than $2 \mathrm{in} / \mathrm{yr}$ (water equivalent).

Annual air temperatures in the Osage Nation average about 59 degrees Fahrenheit $\left({ }^{\circ} \mathrm{F}\right)$, with average daytime high temperatures of about $93^{\circ} \mathrm{F}$ in July and average low temperatures of about $23^{\circ} \mathrm{F}$ in January (Oklahoma Climatological Survey, 2013; Andrews and Smith, 2014). Prevailing winds in this area are southerly and average about 9 miles per hour. Thunderstorms occur on about 50 days annually, predominantly in the spring and summer (Oklahoma Climatological Survey, 2013; Andrews and Smith, 2014).

\section{Land Use}

The study area has undergone minimal land-use change from 1950 to 2014. Pasture, or native grassland, and deciduous forest were the primary land uses in the region and remained at similar amounts during 1950 to 2014 (Sohl and others, 2016). Pasture was about 63 percent of the total land use with an average area of 1,169,000 acres, and much of the pasture was concentrated in the central and western regions of the study area (fig. 2). Deciduous forest was about 27 percent of 


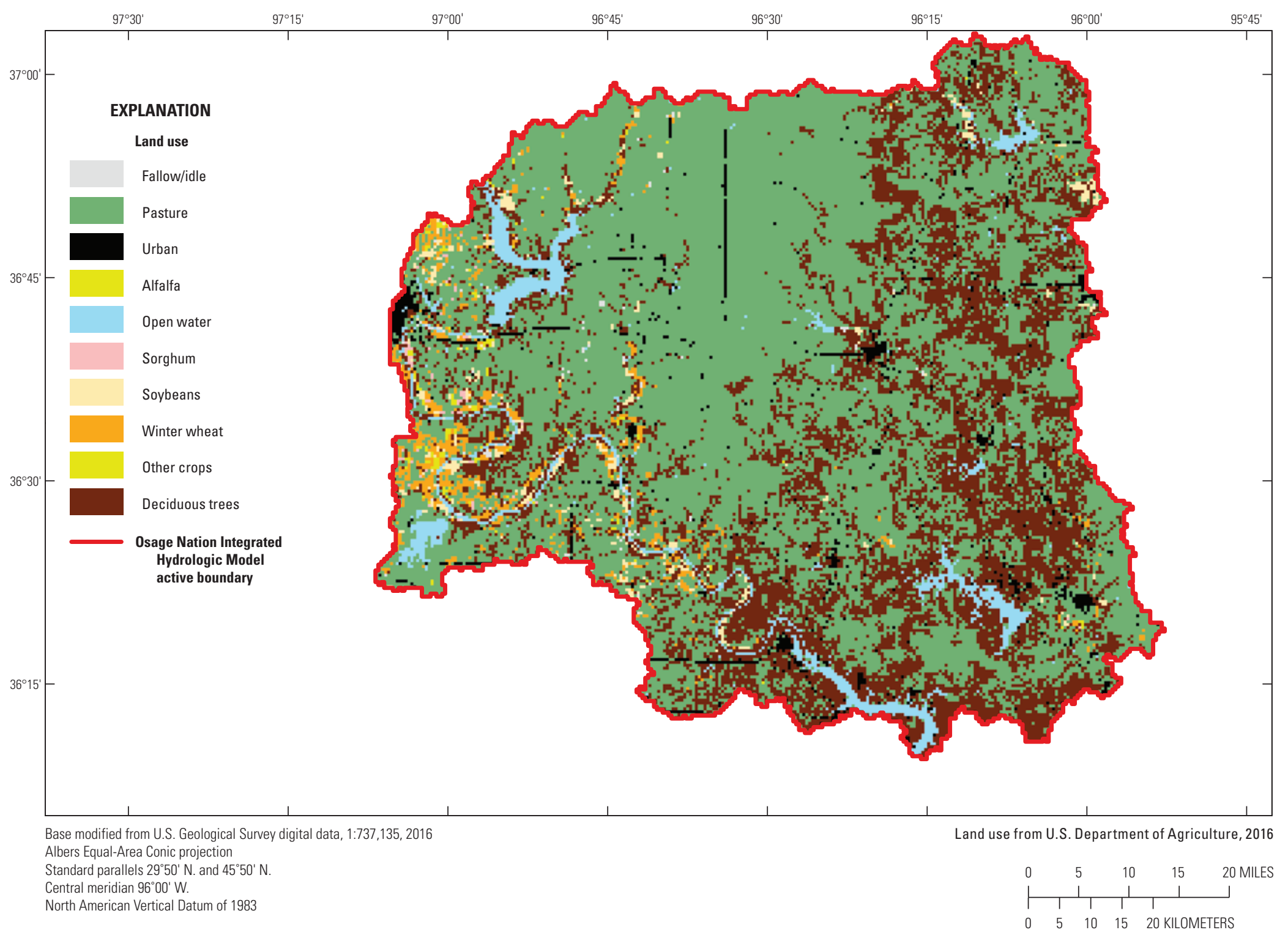

Figure 2. Land-use extents in 2014 for 10 major land-use classes within the Osage Nation Integrated Hydrologic Model active boundary. 
the total land use with an average area of 508,000 acres, and much of the deciduous forest was concentrated around stream valleys and in the eastern and southern regions of the study area. Cropland was about 5 percent of the total land use and was primarily in the western part along the Arkansas River. Developed land, open water, and fallow make up about 5 percent of the remaining land uses (fig. 2).

\section{Surface Water and Groundwater}

A topographic high in the north-central part of the study area acts as a "watershed divide" where streams, originating to the west of the topographic high, flow south to southwest, and streams that originate to the east of the topographic high generally flow east to southeast (see fig. 2 in Hevesi and others, 2020). The largest stream in the study area is the Arkansas River, which enters the study area northeast of Kaw Lake, and flows south about 35 miles before turning to flow southeast along the southern part of the study area. The Arkansas River is impounded by two dams that create Kaw Lake in the northwestern part of the study area near Ponca City, Oklahoma, and Keystone Lake in the southeast part of the study area near Cleveland, Okla. Arkansas River streamflow is 10 times larger than any other stream in the study area (Andrews and Smith, 2014). The Arkansas River has several tributaries. Salt Creek originates in the north-central part of the study area and flows south along the western edge of the topographic high before flowing into the Arkansas River above Ralston, Okla. There are no streamflow data or measurements available for Salt Creek. Hominy Creek near Hominy, Okla., and Skiatook, Okla., Bird Creek at Avant, Okla., and near Sperry, Okla., and Sand Creek at Okesa, Okla. (not shown), all originate east of the topographic high and flow east to southeast where they flow out of the study area. Caney River near Hulah, Okla. (not shown in fig. 1), is a major stream that flows in and out of the northeastern part of the study area. Hominy Creek has a dam that impounds streamflow to create Skiatook Lake, near Skiatook, Okla., and Caney River has a dam that impounds streamflow to create Hulah Lake.

There are 13 USGS streamgages in the study area (fig. 1) with various periods of record (table 1; U.S. Geological Survey, 2016). Of the 13 stations, 8 have streamflows that were affected by reservoir construction and operations during all or part of the period of record. The largest average annual streamflows in the study area are in the Arkansas River, ranging from approximately 3,000 to 6,000 cubic feet per second $\left(\mathrm{ft}^{3} / \mathrm{s}\right)$ (U.S. Geological Survey, 2016). The smallest continuously measured streams are small tributaries such as Birch Creek below Birch Lake near Barnsdall, Okla. (not shown), Candy Creek (not shown) at Wolco, Okla. (not shown), that flows into Bird Creek near Avant, Okla., Ranch Creek (not shown) that flows into the Arkansas at Cleveland Dam (not shown) near Cleveland, Okla., and Greasy Creek (not shown) near Watchorn, Okla. (not shown), that flows into the Arkansas River below Sooner Lake, which have mean streamflows ranging from approximately 10 to $30 \mathrm{ft}^{3} / \mathrm{s}$ (table 1). Mean monthly streamflows are greatest in May and June and lowest in December and January (Andrews and Smith, 2014). The streamflows in the study area are affected by precipitation and multidecadal climate trends (Andrews and Smith, 2014).

\section{Geologic Units}

The geologic units in the study area consist of Quaternary-age alluvium and terrace deposits; the Permian-age Wellington Formation, Oscar Group, and Vanoss Group; and the Pennsylvanian-age Vanoss Group, Ada Formation, Vamoosa Group, Ochelata Group, which includes the Tallant Formation, Barnsdall Formation, Wann Formation, Iola Limestone, and Chanute Formation; Skiatook Group, which includes the Nellie Bly Formation, Hogshooter Limestone, Coffeyville Formation, and the Checkerboard Limestone (table 2, in back of report). The base of the geologic units included in this study is the Coffeyville Formation of the Skiatook Group overlying the Checkerboard Limestone of the Skiatook Group (Hudson and others, 2016). The Checkerboard Limestone of the Skiatook Group was not included in the study because it does not seem to have a hydrologic connection with the overlying Coffeyville Formation of the Skiatook Group (O'Connor, 1974). The Coffeyville Formation overlying the Checkerboard Limestone consists of a black interbedded shale ranging in thickness from 175 to 450 feet (ft) with a Checkerboard Limestone member that is 2 to $15 \mathrm{ft}$ thick at the base of the Coffeyville Formation (Bingham and Bergman, 1980). This black shale that makes up the Coffeyville Formation is assumed to be relatively less permeable than the underlying Checkerboard Limestone of the Skiatook Group and is specified in Montgomery County, Kansas, to yield little to no water (O'Connor, 1974). The Checkerboard Limestone also extends into eastern Kansas (Jewett and others, 1965).

A three-dimensional integrated geological and geophysical model for the study area combined existing geological and newly collected airborne electromagnetic data to refine the areal extent, thickness, and geological structure of 17 geologic formations and members in the study area (table 2, in back of report) (see fig. 5 in Hudson and others, 2016). The geologic structure of Osage County is a west-dipping monocline with formations deepening westward at an average rate of 40 feet per mile (Hudson and others, 2016). Geologic formations and members correlated to the layers in the three-dimensional integrated geological and geophysical model are laterally extensive, of low dip and relief, and broken by minimal faulting. Hudson and others (2016) state that representing the Quaternary alluvial deposits in a model was more complicated because of the narrow and shallow extent of the Quaternaryage alluvium relative other formations, limited data availability, and the nature of the modeling software, so the alluvial deposits may not be as well represented in the geologic model. 
Table 1. Streamgages in the study area, period of streamflow record, average annual streamflow (U.S. Geological Survey, 2016), and average annual base flow.

[fts/s, cubic foot per second; OK, Oklahoma; NA, not applicable; nr, near; Clev, Cleveland]

\begin{tabular}{|c|c|c|c|c|c|c|c|}
\hline \multicolumn{2}{|r|}{ Station information } & \multicolumn{2}{|c|}{ Period of record } & \multirow{2}{*}{$\begin{array}{l}\text { Reservoir } \\
\text { influence } \\
\text { start year }\end{array}$} & \multicolumn{3}{|c|}{ Average flows for period of record } \\
\hline $\begin{array}{l}\text { Station } \\
\text { number }\end{array}$ & Station name & Start date & End date & & $\begin{array}{l}\text { Streamflow } \\
\left(\mathrm{ft}^{3} / \mathbf{s}\right)^{1}\end{array}$ & $\begin{array}{l}\text { Base flow } \\
\left(\mathrm{ft}^{3} / \mathrm{s}\right)^{2,3}\end{array}$ & $\begin{array}{c}\text { Base flow } \\
\text { (percentage of } \\
\text { streamflow) }\end{array}$ \\
\hline 07148140 & Arkansas River near Ponca City, OK & $4 / 22 / 1976$ & $10 / 12 / 2000$ & 1976 & 3,171 & 1,798 & 68 \\
\hline 07152500 & Arkansas River at Ralston, OK & $10 / 1 / 1925$ & $12 / 31 / 2015$ & NA & 5,371 & 2,800 & 71 \\
\hline 07176950 & Hominy Creek near Hominy, OK & $10 / 1 / 2003$ & $9 / 28 / 2007$ & NA & 67 & 15 & 73 \\
\hline 07177000 & Hominy Creek near Skiatook, OK & $4 / 1 / 1944$ & $12 / 30 / 1980$ & NA & 180 & 21 & 58 \\
\hline 07177410 & $\begin{array}{l}\text { Hominy Creek below Skiatook Lake } \\
\text { nr Skiatook, OK }\end{array}$ & $10 / 1 / 1984$ & 9/30/1993 & 1984 & 262 & 140 & 74 \\
\hline 07176500 & Bird Creek at Avant, OK & $10 / 1 / 1945$ & $12 / 31 / 2015$ & 1977 & 243 & 58 & 62 \\
\hline 07177500 & Bird Creek near Sperry, OK & $10 / 1 / 1938$ & $12 / 31 / 2015$ & 1977 & 563 & 176 & 68 \\
\hline 07176465 & $\begin{array}{l}\text { Birch Creek }{ }^{4} \text { below Birch Lake } \\
\text { nr Barnsdall, OK }\end{array}$ & 3/1/1977 & 9/30/1992 & 1977 & 44 & 21 & 82 \\
\hline 07174600 & Sand Creek at Okesa, OK & $10 / 1 / 1959$ & 9/30/1993 & NA & 86 & 20 & 58 \\
\hline 07173000 & Caney River near Hulah, OK ${ }^{5}$ & $10 / 1 / 1937$ & 8/30/1993 & 1951 & 407 & 168 & 72 \\
\hline 07176800 & Candy Creek ${ }^{4}$ near Wolco, OK & $10 / 13 / 1969$ & $4 / 28 / 1981$ & NA & 25 & 6 & 56 \\
\hline 07153100 & $\begin{array}{l}\text { Ranch Creek }{ }^{4} \text { at Clev Dam } \\
\text { nr Cleveland, OK }\end{array}$ & $12 / 1 / 1944$ & 9/30/1963 & 1935 & 10 & 3 & 64 \\
\hline 07152290 & Greasy Creek ${ }^{4}$ near Watchorn, OK & $7 / 1 / 1974$ & $6 / 30 / 1976$ & 1972 & 14 & 2 & 65 \\
\hline
\end{tabular}

${ }^{1}$ U.S. Geological Survey, 2016.

${ }^{2}$ Base-flow estimation method, Barlow and others, 2015.

${ }^{3}$ Base-flow estimates generally overestimate base flow due to reservoir operations that release water, which can obscure the low flow signal of streams.

${ }^{4}$ Not labeled in figure 1 .

${ }^{5}$ Hulah, Okla., not shown in figure 1 and no longer exists.

\section{Hydrostratigraphic Framework and Units}

A hydrostratigraphic unit is typically one or more geologic units or a zone within a geologic unit delineated based on hydraulic properties and has a distinct effect on the storage or movement of groundwater (American Nuclear Society, 1980). Hydrostratigraphic units consist of aquifers (a formation, group of formations, or part of a formation that contains sufficient saturated, permeable material to yield adequate quantities of water to wells and springs [Carter and others, 2002]) and confining units (a relatively low permeability geologic unit that impedes the vertical movement of water [Carter and others, 2002]). There are three primary regional aquifers underlying the Osage Nation: the alluvial and terrace aquifers (referred to hereafter as "alluvial aquifers") that consist of Quaternary-age unconsolidated sands, silts, clays, and gravels deposited along streams and rivers; the Vamoosa-Ada aquifer that is contained in Pennsylvanian-age sequences of sandstones, siltstones, shales, conglomerates, and limestones deposited in marine environments; and the minor Pennsylvanian bedrock aquifers that consist of multiple geologic units of the Pennsylvanian Period that outcrop in the eastern part of the study area and underly the Vamoosa-Ada aquifer in the west (table 2, in back of report). The geologic units that make up these aquifers were incorporated into the hydrostratigraphic framework as distinct units and in the integrated hydrologic model as model layers (table 2, in back of report). All other geologic units were considered confining or semiconfining hydrostratigraphic units (table 2, in back of report).

Fresh groundwater is most abundant in alluvial aquifers along streams and in the Vamoosa-Ada aquifer (Bingham and Bergman, 1980; D'Lugosz and others, 1986; Mashburn and others, 2003). Yields of groundwater from the minor Pennsylvanian bedrock aquifer, which include thin layers of sandstone and limestones, are somewhat small (Bingham and Bergman, 1980; Andrews and Smith, 2014). Fresh groundwater in the minor Pennsylvanian bedrock aquifer is underlain by brines containing large concentrations of sodium and chloride and total dissolved solids concentrations as large as $200,000 \mathrm{mg} / \mathrm{L}$ (D'Lugosz and others, 1986), either because the groundwater is connate water (seawater trapped in pores at the time of deposition) or because groundwater dissolved minerals in 
rocks and sediment from long residence times and became more saline. Permian-age formations in Oklahoma consist of evaporites and considerable gypsum; the groundwater in these units consists of (in decreasing order of milliequivalent concentrations) calcium carbonate, calcium sulfate, magnesium sulfate, sodium sulfate, and sodium chloride (Smith and others, 1942). Pennsylvanian-age formations in Oklahoma consist of sandstones, shales, and limestones and the groundwater in these units consists of (in decreasing order of milliequivalent concentrations) calcium carbonate, magnesium carbonate, sodium sulfate, and sodium chloride (Smith and others, 1942). The Permian-age formations and their associated calcium sulfate evaporites were not considered in this study area because these evaporites are not present in the Permian units of eastern Oklahoma that includes the Osage Nation (Jordan and Vosburg, 1963).

The alluvial aquifers yield moderate to large amounts of water with well yields ranging from 20 to 500 gallons per minute (gal/min) and transmissivity (calculated from grain size analyses) ranging from 2,000 to 26,000 feet squared per day (Mashburn and others, 2003; Andrews and Smith, 2014). About 30 percent of the water samples collected in the Arkansas River alluvial aquifer had total dissolved solids concentrations that exceed the secondary drinking-water standard for freshwater of $500 \mathrm{mg} / \mathrm{L}$ (Mashburn and others, 2003). Additionally, the total dissolved solids concentration of samples collected from alluvial aquifers adjoining the Arkansas River ranged from 88 to 3,658 mg/L, which indicates that the groundwater is fresh to saline (Mashburn and others, 2003). The Vamoosa-Ada aquifer yields are larger in areas to the south and southwest where the hydrostratigraphic unit is coarser grained and thicker. Wells in the VamoosaAda aquifer yield 6-55 gal $/ \mathrm{min}$ of freshwater to marginal water, with transmissivities ranging from 21 to 1,000 feet squared per day, with total dissolved concentrations that can vary locally (D'Lugosz and others, 1986; Abbott and DeHay, 2008; Andrews and Smith, 2014). About 60 percent of the water samples collected from the Vamoosa-Ada aquifer had total dissolved solids concentrations that exceed the secondary drinking-water standard for freshwater of $500 \mathrm{mg} / \mathrm{L}$ (Mashburn and others, 2003; Andrews and Smith, 2014). Further, total dissolved solids concentrations in the VamoosaAda aquifer generally increase with depth (D'Lugosz and others, 1986). The minor Pennsylvanian bedrock aquifer is less productive and yields $6-15 \mathrm{gal} / \mathrm{min}$ of primarily marginal (dissolved solids concentration 500 to $1,500 \mathrm{mg} / \mathrm{L}$ ) to nonpotable saline water (dissolved solids concentration greater than 1,500 mg/L; D'Lugosz and others, 1986). The entire Osage Nation is underlain by brines with total dissolved concentrations as much as 200,000 mg/L (D'Lugosz and others, 1986; Andrews and Smith, 2014).

Groundwater use in the study area is for the purposes of public supply, self-supplied domestic, and self-supplied industrial. Other purposes include irrigation, livestock, and aquaculture (Andrews and Smith, 2014). Water-use estimates from 1890 to 2010 demonstrate that total groundwater use is less than 2 million gallons per day for 22 of the 25 surveyed years between 1890 and 2010 (see table 12 in Andrews and Smith, 2014).

\section{Conceptual Model of the Hydrologic System}

The conceptual model of a hydrologic system is a schematic of the water cycle for a given study area that identifies and describes where water is stored and exchanged. Three main components of the hydrologic system represented in the conceptual model were the landscape water, surface water, and groundwater. Each component contains reservoir and flux elements, where the reservoirs store water and the fluxes are inflows and or outflows of water. A conceptual model, to the extent possible, also describes the approximate magnitude of the reservoirs and fluxes of water between each component of the hydrologic system (referred to as "water budgets") to create a blueprint for construction of a numerically based integrated hydrologic-flow model. After the numerical model is constructed to best represent the conceptual flow model, the conceptual flow model water budget becomes a general metric that is used to determine the efficacy of the simulated water budget during and after the numerical model construction and calibration.

For this study area, inflows for the conceptual model of the hydrologic system were primarily from precipitation and streamflow entering at study area boundary. Precipitation falls on the land surface where it is either taken up by plants as evapotranspiration (ET), runs off into streams, or seeps through the root zone and recharges the water table in the underlying aquifer. Once recharge arrives at the water table and becomes groundwater, it either replenishes groundwater storage or flows downgradient in the alluvial or bedrock aquifer matrix and discharges as base flow to streams. It should be noted that recharge is water moving from the soil to the groundwater-flow system. In an area to the south of the study area with mean annual precipitation of 40 in., annual recharge rates range from 4 to 10 percent of annual precipitation (Wilkins, 1997); recharge in the study area was assumed to be highest in valleys near streams and lowest along hillslopes (Hevesi and others, 2020). The primary outflows were ET of precipitation and groundwater by plants, runoff of precipitation to streams, and discharge of groundwater to streams as base flow (D'Lugosz and others, 1986; Andrews and Smith, 2014).

\section{Components of the Hydrologic System}

This section of the report describes the three components of the hydrologic system (landscape, surface water, and groundwater) relevant to this study. The inflows and outflows and hydrologic characteristics within each component that 
affect the storage and movement of water are also described. Additionally, magnitudes of each inflow or outflow are quantified if the data exist.

\section{Landscape}

The landscape is the component of the hydrologic system with fluxes that include inflows from precipitation and irrigation application and outflows to ET, runoff, and deep percolation (recharge to the water table). Precipitation is a major inflow to the hydrologic system and affects ET, streamflow, and water-table dynamics on short-term (daily and monthly) and long-term (annual and decadal) time scales. The majority of annual precipitation (annual average 36 in.) commonly falls in the form of intense rainfall events like thunderstorms during the spring and early summer months. Thunderstorm precipitation rates can exceed soil infiltration rates, thus promoting more runoff than recharge during these events. Precipitation is lowest during the winter months with smaller precipitation amounts falling in the form of snow (Andrews and Smith, 2014).

The landscape fluxes are influenced by landscape properties that includes land use, soil type, and ET characteristics. Land-use properties were important to define because they are key factors that affect runoff, infiltration, and recharge properties. Runoff properties for a given area are a function of several criteria that include (1) slope and aspect, (2) percentage of impervious land, (3) percentage of canopy cover, (4) soil texture and vertical hydraulic conductivity, (5) surface geology, and (6) upstream area. However, this level of detail was outside the scope of the study for a regional integrated hydrologic-flow model; therefore, runoff properties were homogenized into parameters that change for each type of land use (fig. 2). The primary land use was native pasture (62.73 percent or $1,166,035$ acres as of 2014) (referred to hereafter as "pasture"), which is grazed by cattle. A total of 2 percent of the study area $(39,650$ acres) was designated as pasture conservation areas; these grass areas were typically grazed by bison and burned periodically - about every 3 years (Williams, 2017). For simplicity, all pasture in the model was assumed to be grazed. If the grass is extensively grazed, then the grass is shorter and promotes runoff, whereas taller grass that is more conservatively grazed decreases runoff (U.S. Department of Agriculture, 2017). Data about grazing practices, which could be used to characterize runoff values, were not available for this area; however, field reconnaissance by the authors and oral communication with local Osage Nation Environmental and Natural Resources Department personnel confirmed that most of the grass in the study area, not including conservation areas, is extensively grazed by cattle during the growing season (early April to late October) (Craig Walker, Osage Nation Environmental and Natural Resources Department, oral commun., 2017). Deciduous forest was the second most common land use (26.76 percent or 497,521 acres as of 2014) and was most common along streams and along steeper valleys. Consequently, runoff rates were assumed to be higher for the deciduous forest land use than other types along steeper slopes (Hevesi and others, 2020).

Soils in the study area are a mix of sand (10 percent of study area), loam (85 percent), and clay (5 percent) (U.S. Department of Agriculture, 2014). Sandy soils overly the Arkansas River alluvial aquifer and are present throughout the eastern part of the study area; sandy soils generally promote recharge because they are the most porous soil type. Loamy soils are present throughout the study area and generally promote more runoff than sandy soils because of a decrease in porosity and vertical hydraulic conductivity. Clayey soils, present mostly in the northern part of the study area, have the lowest porosity of the classified soil types in the study area and promote the most runoff (Hillel, 1980). Soil depths in the study area are mostly shallow, with the underlying bedrock partially exposed throughout the study area. The thin soil layer reduces soil infiltration capacity and promotes runoff. Based on the combination of land use, soil types, soil thickness, and hydrographs of streamflow that indicate responses to precipitation events, the percentage of precipitation that contributes to runoff was assumed to be greater than the percentage of precipitation that goes to recharge. Surface-water analysis using a Precipitation Runoff Modeling System (PRMS) model was used to estimate that runoff was about 10 percent of precipitation and recharge to the water table was about 3 percent of precipitation (Hevesi and others, 2020).

ET was a major outflow component in the hydrologic system. ET consumed about 77 percent of the total inflow from precipitation based on the PRMS model (fig. 1; Hevesi and others, 2020). Monthly potential evapotranspiration (PET) rates were highest during the growing season, peaking in July and August, and lowest in the winter months with the minimum in December and January (fig. 3). The PRMS model, whose domain encompassed the study area of this report (fig. 1), produced PET estimates that were calibrated to PET values derived from field measurements at 14 Oklahoma Climatological Survey Mesoscale Network (Mesonet) field stations in the study area (Hevesi and others, 2020).

\section{Surface Water}

The surface-water network in the study area includes six major streams and their tributaries and six major man-made reservoirs. The six major streams generally flow from west to east. The streams west of the topographic high (upstream part of the Arkansas River and Salt Creek) flow south to southwest, and streams east of the topographic high (Caney River, Sand Creek, Bird Creek, and Hominy Creek) generally flow east to southeast (fig. 1). The seven major man-made reservoirs in the study area include Kaw and Keystone Lakes, which impound the Arkansas River; Hulah Lake, which impounds the Caney River; Bluestem Lake (not shown), which impounds Bird Creek; Skiatook Lake, which impounds Hominy Creek; Birch Lake (not shown), which impounds Birch Creek (not shown), and Sooner Lake, which impounds Greasy Creek (not shown) (fig. 1). 


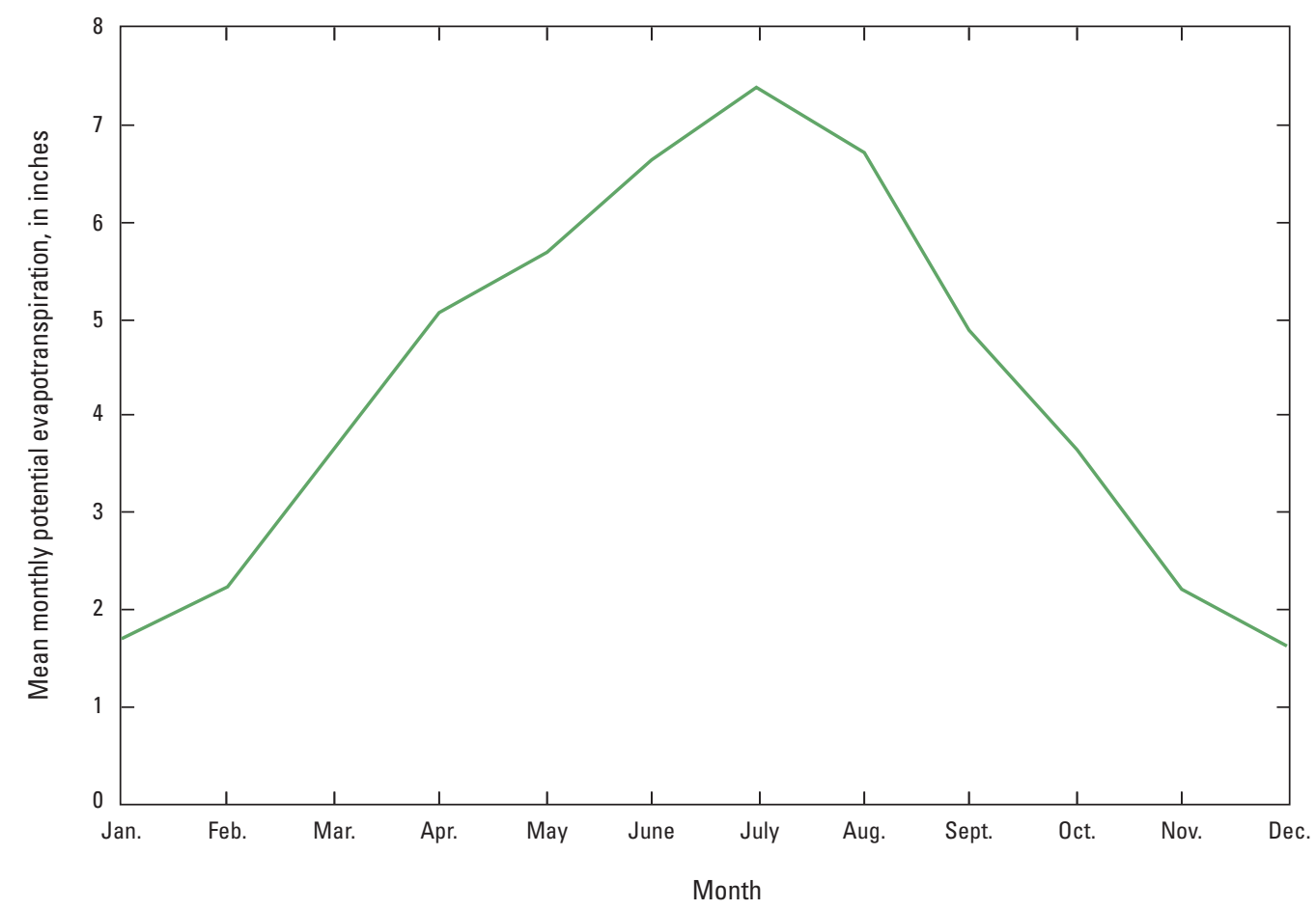

EXPLANATION

Mean monthly potential evapotranspirationModified from Hevesi and others (2020)

Figure 3. Mean monthly potential evapotranspiration within the Osage Nation Integrated Hydrologic Model active boundary from January 1950 to September 2014 (modified from Hevesi and others [2020]).

Streamflows generally increased downstream and consisted of runoff from precipitation and groundwater discharge as stream base flow. The major streams and many of their tributaries generally receive discharge as base flow throughout the year; however, some reaches of several streams may demonstrate induced infiltration of stream water into the underlying aquifer. For example, the upper reach of the Arkansas River from its inflow point into the study area to the streamgage below Kaw Lake (Arkansas River near Ponca City, Okla., USGS station 07148140) was a losing reach of about $8 \mathrm{ft}^{3} / \mathrm{s}$ per mile, whereas the reach from below Kaw Lake to Ralston was a gaining reach of about $10 \mathrm{ft}^{3} / \mathrm{s}$ per mile (U.S. Geological Survey, 2016).

Streamflow variations were due to precipitation events, ET dynamics, and reservoir operations. The percentage of cumulative mean annual streamflow for most streams in the study area is largest during March through June, averaging 54 to 62 percent (Abbott and Tortorelli, 2002). The percentage of cumulative mean annual streamflow is smallest during December, January, July, and August, averaging only 14 to 21 percent (Abbott and Tortorelli, 2002).

Most of the streams in the study area flow across multiple surficial geologic units; for example, Hominy Creek originates in the center of the study area and flows southeast over the Permian Oscar and Vanoss Groups, Pennsylvanian Ada Formation and Vamoosa Group, and the Quaternary alluvial and terrace deposits before exiting the study area in the southeast corner about 10 miles north of Tulsa, Okla. (fig. 1 and fig. 4). Because detailed information about streambed characteristics were not available, it was assumed that streambed vertical hydraulic conductivity $(K s b)$ is generally associated with the dominant soil type in the area or hydrostratigraphic unit underlying the stream; however, for this study, streams commonly incised down to the underlying bedrock because soil thickness was minimal or absent for many streams. Therefore, for this study, $K s b$ was assumed to be similar to the hydraulic conductivity of the underlying hydrostratigraphic unit.

\section{Groundwater}

Insufficient water-level data exist within the study area to determine precise groundwater-flow directions or to create a detailed water table map; however, in this area, the water table is generally accepted to be similar in form to the land surface and so, groundwater generally flows from topographic highs in the study area toward streams (Andrews and Smith, 2014). Water-table maps of the Vamoosa-Ada aquifer from Andrews and Smith (2014) document a general groundwater-flow direction from west to east and more locally from topographically high areas toward streams in low lying topographic areas. Groundwater-flow velocities are likely highest in the alluvial areas with sandy sediments and more porous hydrostratigraphic units and lowest in the lower 


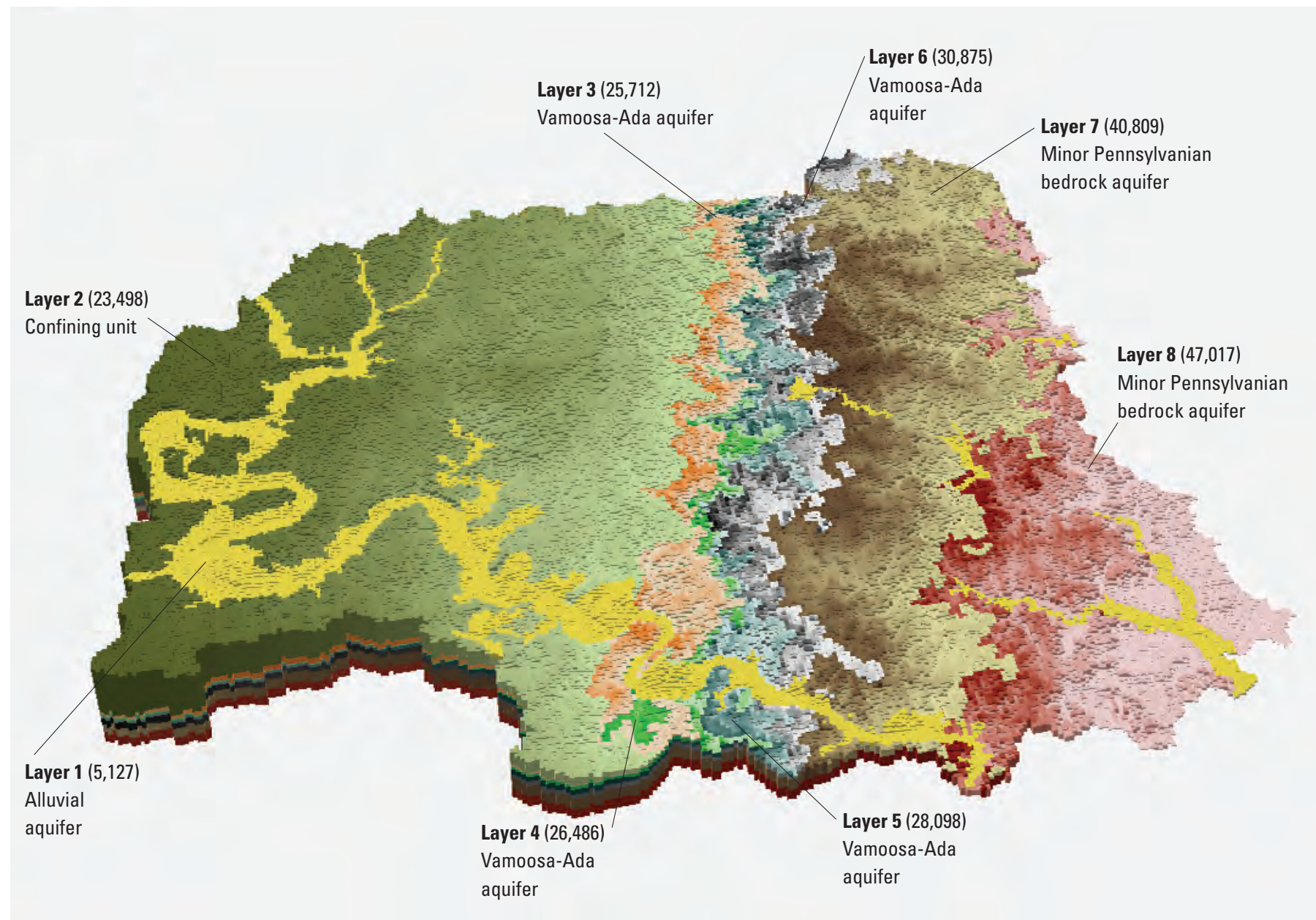

EXPLANATION

Layer $1(5,127) \quad$ Layer number indicates the Osage Nation Integrated Hydrologic Model layer-

Modified from Hudson and others (2016). Number in parenthesis indicates active cells

Alluvial Aquifer name is the hydrostratigraphic unit (table 2)

aquifer

Figure 4. Side view of the active cells for each of the Osage Nation Integrated Hydrologic Model layers and their corresponding hydrostratigraphic layers (Traylor and Peterson, 2021).

porosity hydrostratigraphic units outside of the alluvial aquifer (Andrews and Smith, 2014; Hudson and others, 2016).

Base flow separation analysis of daily streamflows at USGS streamgages using the Hydrograph Separation Program HYSEP-Slide method from the USGS Groundwater Toolbox (Barlow and others, 2015) estimated average annual base flow from 50 to 80 percent of total streamflow when averaged over the period of record (table 1). However, 9 of 15 streamgages used for base flow analysis were downstream from reservoirs for substantial parts of their period of record (table 1). These base flow estimates generally overestimate base flow due to reservoir operations that release water, which can obscure the low flow signal of streams.

\section{Aquifer Properties}

The hydrostratigraphic units dip toward the west and outcrop in the east (fig. 4) and are unconfined where they crop out and confined where they are overlain by other hydrostratigraphic units in the western parts of the study area. Only two hydrostratigraphic units, the alluvial aquifer and the VamoosaAda aquifer are considered major aquifers having groundwater well yield averages of 6-55 gal/min (Andrews and Smith, 2014). The high-capacity nonirrigation wells, hereafter referred to as "production wells," and irrigation wells (typically with the largest rates of withdrawal) are present almost exclusively in the Arkansas River portion of the alluvial 
aquifer (fig. 5). Data from the Oklahoma Water Resources Board groundwater database (Oklahoma Water Resources Board, 2016) indicated that the alluvial aquifer, Oscar Group, Vanoss Group, and minor Pennsylvanian bedrock aquifer have many domestic wells and that few wells of any type have been drilled in Vamoosa-Ada aquifer (table 3). The domestic wells have low well yields (assumed to be less than $5 \mathrm{gal} / \mathrm{min}$ ) and limited fresh groundwater use (see table 12 in Andrews and Smith, 2014) which is consistent with the conceptual model that the Oscar Group and Vanoss Group did not yield much water to wells.
The alluvial aquifer is assumed to have the highest values of horizontal hydraulic conductivity $(K h)$ and specific yield $\left(S_{y}\right)$ in the study area, in the ranges of 6.5 to 660 feet per day (ft/d) and 0.1 to 0.2 , respectively (Mashburn, 2003). The ratio of horizontal to vertical hydraulic conductivity in the alluvial aquifer is assumed to be between 1:1 and 2:1, which is a standard value for unconsolidated sands and gravel deposits typically present in the study area (Domenico and Schwartz, 1990). The alluvial aquifer is unconfined throughout the study area (fig. 4).

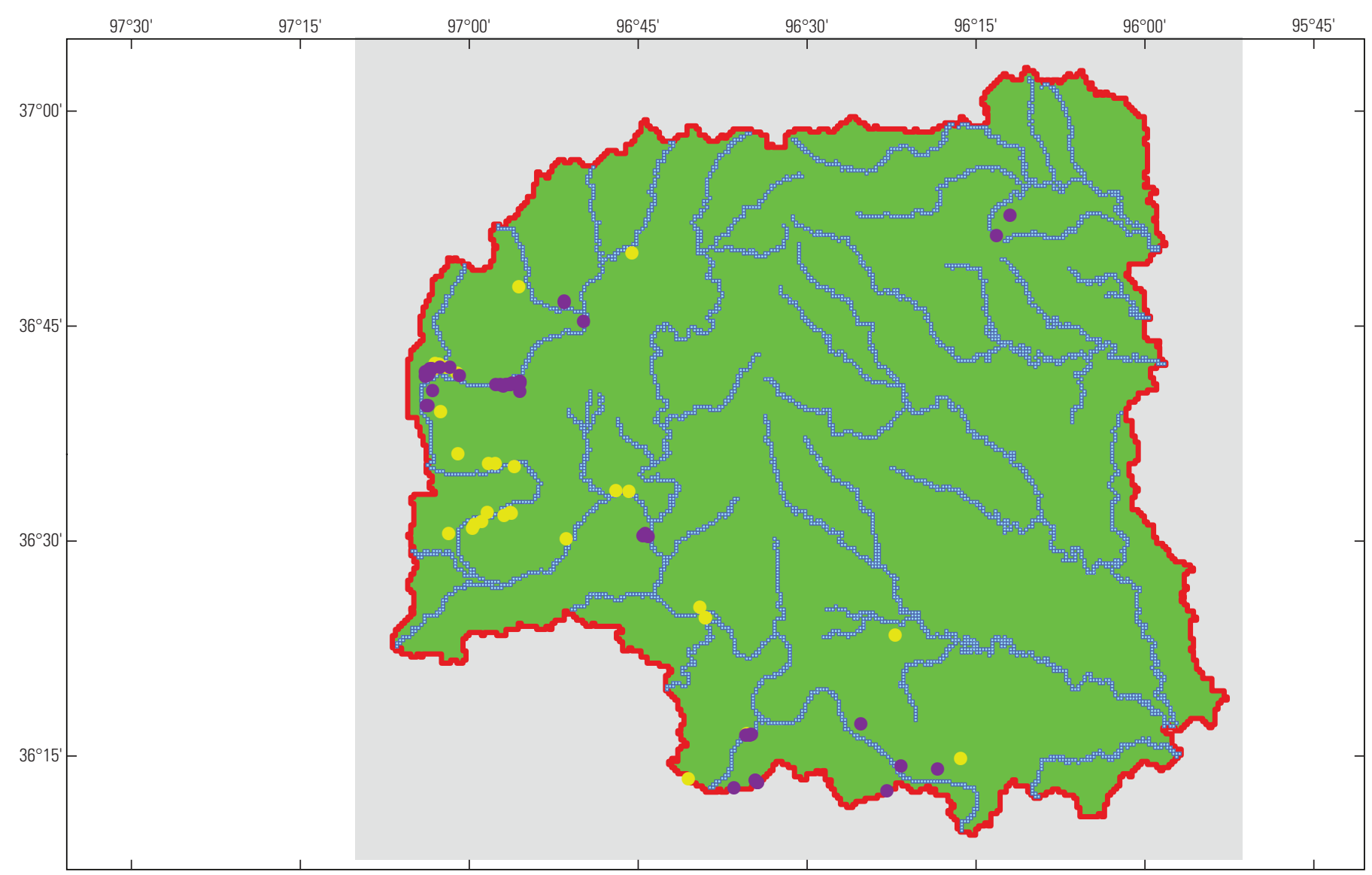

Base modified from U.S. Geological Survey digital data, 1:737,135, 2015 Albers Equal-Area Conic projection

Standard parallels $29^{\circ} 50^{\prime} \mathrm{N}$. and $45^{\circ} 50^{\prime} \mathrm{N}$.

Central meridian $96^{\circ} 00^{\prime} \mathrm{W}$.

North American Vertical Datum of 1983

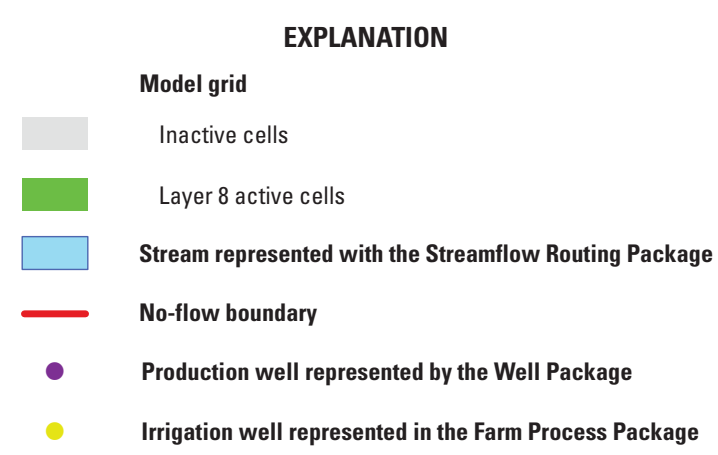

Figure 5. Total active and inactive model cells, boundary conditions, stream cells simulated with the Streamflow Routing Package, production wells, and irrigation wells in the Osage Nation Integrated Hydrologic Model across all layers (Traylor and Peterson, 2021). 
Table 3. Well counts by geologic or hydrostratigraphic unit within the Osage Nation Integrated Hydrologic Model extent (Oklahoma Water Resources Board, 2016).

\begin{tabular}{cccccc}
\hline \multirow{2}{*}{ Unit } & \multicolumn{5}{c}{ Well type } \\
\cline { 2 - 6 } & Domestic & Industrial & Irrigation & Production & Other \\
\hline $\begin{array}{c}\text { Alluvial aquifer } \\
\text { Oscar and }\end{array}$ & 165 & 10 & 46 & 73 & 67 \\
$\begin{array}{c}\text { Vanoss Group } \\
\text { Vamoosa-Ada } \\
\text { aquifer }\end{array}$ & 214 & 0 & 7 & 10 & 64 \\
$\begin{array}{c}\text { Minor } \\
\text { Pennsylvanian } \\
\text { bedrock aquifer }\end{array}$ & 334 & 0 & 0 & 7 & 32 \\
\hline
\end{tabular}

The formations containing the Vamoosa-Ada aquifer crop out throughout the central part of the study area (fig. 4), and the aquifer is confined where it is overlain by other hydrostratigraphic units. The Vamoosa-Ada aquifer and is assumed to have a slightly higher hydraulic conductivity, about $3 \mathrm{ft} / \mathrm{d}$, and specific yield, about 0.12 , than other layers, except the alluvial aquifer (D'Lugosz and others, 1986). The VamoosaAda aquifer also is more anisotropic than the alluvial aquifer (D'Lugosz and others, 1986) with a ratio of horizontal to vertical hydraulic conductivity as much as 10,000:1 due to the presence of shale (Domenico and Schwartz, 1990).

\section{Fresh/Marginal Groundwater and Saline Groundwater Interface}

The primary source of recharge to the alluvial and Vamoosa-Ada aquifers is rainfall (precipitation) that moves through the unsaturated zone and reaches the water table. Once there, the freshwater remains in the upper portion of the aquifer and overlies older, connate, saline groundwater. Evaporites that can contribute to saline groundwater are not present in the stratigraphy of the study area and are present farther west of the study area in Permian Basin red beds (Johnson, 1997). Further, the dissolution of evaporites produces calcium sulfate type groundwater, but the saline groundwater underlying the Osage Nation is of the sodium chloride type (Andrews and Smith, 2014). Comparison of bromide concentrations in some groundwater and stream water-quality samples indicated that mineralization of groundwater by petroleum-linked brines has occurred in some parts of the study area (D'Lugosz and others, 1986). The interface between freshwater and saline water is likely sharp where the freshwater in the aquifer is underlain by less permeable geologic units; however, where the aquifer is underlain by permeable geologic units, the interface likely grades from fresh to saline water over hundreds of feet. Greater amounts of freshwater recharge in the upper part of the aquifer and the higher density of saline water prevent the saline water from migrating upward. The depths to which freshwater extends into the aquifer is based on the hydrogeologic properties of the unit, the outcrop extent of the unit, recharge rates, and the dominant groundwater-flow direction in the unit. In areas of alternating horizontal layers of permeable and less permeable materials, freshwater can extend into less permeable materials and create multiple vertical zones of freshwater separated by saline water. Andrews and Smith (2014) used the base of potable water map delineated in D'Lugosz and others (1986) to approximate the altitude of the base of potable water, defined in D'Lugosz and others (1986) as up to $1,500 \mathrm{mg} / \mathrm{L}$ of dissolved solids and includes fresh and marginal groundwater, for two transects across the VamoosaAda aquifer, which generally indicated larger freshwater saturated thickness in the eastern regions of the Vamoosa-Ada aquifer. Water-quality data indicated that the range of total dissolved solids concentrations in the alluvial aquifer and the minor Pennsylvanian bedrock aquifer were similar to the concentrations in the Vamoosa-Ada aquifer (see fig. 23 in Andrews and Smith, 2014).

As a part of this study, a new base of marginal groundwater map was constructed for the fresh/marginal groundwater and saline groundwater interface (fig. 1). The new base of marginal groundwater map used data from D'Lugosz and others (1986), additional water-quality data described in Andrews and Smith (2014), which were collected in Osage County after D'Lugosz and others (1986), and existing geophysical data (Boyd, 2011). The additional water-quality data generally were from wells yielding freshwater that typically had depths less than $300 \mathrm{ft}$ below land surface; only four of samples were from wells screened in the deeper marginal to saline parts of the aquifers. To supplement these water-quality data and existing geophysical data (Boyd, 2011), newly collected geophysical logs from Hominy Creek, Arkansas River-Ralston, and Bird Creek were also used (Hudson and others, 2016). Approximately $30 \mathrm{M}$-series cross sections were constructed from geophysical logs, which were described by Boyd (2011) and Hudson and others (2016) and located at sites termed "Cole cross-section boreholes" in figure 1; these geophysical logs contain about 1,450 wire-line geophysical logs that run north to south and east to west across Osage County. The geophysical logs typically contained resistivity, spontaneous potential, and gamma ray logs; however, a few logs also contained induction resistivity logs (also referred to as conductivity logs). Methods described in Hart (1966), Asquith and Gibson (1982), Keys (1990), and Westjohn and Weaver (1991) were applied to these water-quality and geophysical data to delineate a new base of marginal groundwater map (fig. 1). Additionally, if depths to the marginal/saline groundwater contact were shallower than the surface casing depth, then a pick of the contact could not be determined on the geophysical borehole logs. In areas where there seemed to be multiple zones of freshwater occurring vertically in the geophysical $\log$, the shallowest base of marginal groundwater was selected. It should be noted that excluding the peripheral zones of fresh to marginal groundwater where these overlapping zones 
occur would result in an underestimate of the available fresh/ marginal groundwater but including these peripheral zones would result in an overestimate of the available fresh/marginal groundwater. Examination of the geophysical logs (120 points; Boyd, 2011) and data from control points (20 points) in the western part of Osage County indicated an absence of shallow freshwater (Traylor and Peterson, 2021). The data from the geophysical logs and estimated control points, which constrained the interpolation between geophysical data, were used to create a contour map of the base of marginal groundwater (total dissolved solids concentration less than $1,500 \mathrm{mg} / \mathrm{L}$ ) for the study area (fig. 1).

\section{Integrated Hydrologic-Flow Model}

This section of the report describes the integrated hydrologic-flow model of the Osage Nation in northeastern Oklahoma, called the ONIHM, including the ONIHM construction and linkage with the PRMS model from Hevesi and others (2020), ONIHM calibration approach, ONIHM calibration results, and assumptions and limitations. The ONIHM was developed to (1) characterize the 1950-2014 conditions for the analysis of the use and movement of water throughout the Osage Nation and (2) provide a tool for stakeholders to address water availability. The ONIHM used a MODFLOWbased, finite-difference, integrated hydrologic-flow modeling software called MODFLOW One-Water Hydrologic Model (MF-OWHM; Hanson and others, 2014; Boyce and others, 2020). This integrated modeling approach permits a more detailed and realistic simulation of landscape processes than sequentially coupled models and allows the model to track the use and movement of water, internally and without interruption, across the landscape and as surface-water and groundwater-flow components of the hydrologic cycle (Hanson and others, 2014; Boyce and others, 2020).

\section{Integrated Hydrologic-Flow Model Construction and Discretization}

This section of the report describes how the conceptual model of the Osage Nation hydrologic system was represented in the ONIHM simulation. This section includes descriptions of spatial and temporal discretization, selection of model layers, initial conditions, and boundary conditions specified for the ONIHM. Data generated during this study are available as a USGS data release (Traylor and Peterson, 2021).

\section{Spatial Discretization and Layering}

To spatially discretize the model and simulate the hydrologic system using MF-OWHM, the study area was dissected into a three-dimensional finite-difference grid of orthogonal blocks, or cells, and multiple vertical layers of varying thicknesses and areal extent, called model layers. The maximum extent of the orthogonal grid covered 3,153,618 acres and consisted of 79,764 active and inactive cells across 276 rows and 289 columns. The "active" cells in the orthogonal grid simulated the stresses of the hydrologic system, described in the "Conceptual Model" section, and solved the groundwater-flow equations (fig. 4). The "inactive" cells did not contribute to the model solution but were required to create an orthogonal grid (fig. 5). Each cell had uniform sides of $1,312.34 \mathrm{ft}$. Property values (such as $K h$ ) and stresses (such as precipitation) are constant within the spatial extent of each cell and can vary spatially across the model domain.

The 17 three-dimensional geology model layers from Hudson and others (2016) that consisted of seven hydrostratigraphic units in the study area were represented with eight vertical layers in the ONIHM (fig. 4). The altitude of the top of the hydrologic model, representing land surface, was taken from the mean value of the 10-meter National Elevation Dataset digital elevation model (DEM; Gesch and others, 2009) within each cell. All layers were simulated as convertible, meaning they start as unconfined where they are exposed at the surface and confined where they are underlying other units, which allowed the model to update conditions automatically as hydraulic heads changed during the transient simulation. The eight vertical layers varied in thickness and spatial extent. The thinnest layer, with an average thickness of $59.3 \mathrm{ft}$, was layer 4 , and the thickest layer, with an average thickness of $644.2 \mathrm{ft}$, was layer 2. Where layers thinned to less than $9.8 \mathrm{ft}$, they were not simulated; therefore, the minimum thickness for each layer was $9.8 \mathrm{ft}$ (table 2, in back of report).

\section{Temporal Discretization}

The 1950-2014 model simulated the period from January 1950 to September 2014 under transient conditions and was divided into 777 monthly stress periods. The 1950-2014 model was broken into monthly stress periods to adequately simulate the streamflow responses to precipitation events and the dynamic pattern of ET, especially for native vegetation. Specified stresses such as precipitation are constant within each stress period. Stress periods were further divided into weekly time steps (four time steps per stress period) to facilitate numerical computations by the model. The PRMS model developed in Hevesi and others (2020) that preceded the ONIHM, and that provided several ONIHM input datasets, had a transient simulation period from 1915 to 2014. For the ONIHM, climate data were used to select the starting year of the transient simulation because there were insufficient water-level and streamflow data that could be used to constrain the model during calibration before 1950 . The cumulative departure from mean precipitation indicated that the 1940s were climatically a somewhat steady period with no particularly wet or dry years relative to other decades in the 20th century, and given the high responsiveness of streamflow to precipitation, January 1, 1950, was selected to provide the model a starting year that was preceded by somewhat steady 
climate conditions. The end of the transient model simulation (September 30,2014) was set as coincident with the end of the PRMS model simulation from Hevesi and others (2020).

Initial water levels were defined for all model cells for the start of the transient model simulation. The initial water levels used for this model were generated by an earlier prototype version of the same eight-layer MF-OWHM model for this study. The use of prototype transient model-generated water levels as initial water levels for the ONIHM transient model simulation was assumed to be viable because hydrostratigraphy indicated low $K h$ values and slow groundwater-flow velocities in all areas except for the alluvial aquifer represented by ONIHM layer 1. Long-term water-level hydrograph records from some shallow wells (less than $100 \mathrm{ft}$ ) screened in unconfined aquifers indicated 3.28- to $16.40-\mathrm{ft}$ changes that correlated with precipitation events (USGS observation well 364210097025401; well location shown on fig. 1, waterlevel data plotted on fig. 6); water-level records from other shallow wells demonstrated about a 3- to 8-ft change from 1978 to September 2014 and demonstrated less influence from precipitation (USGS observation well 363058096440101; well location shown on fig. 1, water-level data plotted on fig. 6). The study area experienced minimal anthropogenic stresses such as irrigation (USGS observation wells 363058096440101 and 363727096143201 ; well locations shown on fig. 1, waterlevel data plotted on fig. 6). The minimal effect from anthropogenic stress coupled with the low $K h$ contributed to approximately static water levels and groundwater-flow system for most of the transient model simulation period.

\section{Boundary Conditions}

Boundary conditions were specified for cells that represented the interface between different hydrologic components as identified in the conceptual model. A spatially and temporally accurate depiction of the boundary conditions is necessary for the hydrologic-flow model to accurately simulate inflows and outflows across the various boundaries. The ONIHM used three types of boundary conditions: head-dependent boundaries, no-flow boundaries, and specified flux boundaries. For a head-dependent boundary, flows across the boundary are simulated based on the relation between the simulated water-level and a user-specified altitude and hydraulic conductance for that cell. No-flow boundary cells do not yield water, and they prohibit the transmission of water across that cell regardless of the water level in the surrounding cells. Specified flux boundary cells transmit water at a user-specified rate across said boundary.

No-flow groundwater boundaries were used for the deepest extent of the model and the perimeter. The lowest hydrostratigraphic layer in the model was the Coffeyville Formation (layer 8, table 2, in back of report). The Coffeyville Formation is predominantly shale and is assumed to not be hydrologically connected with the poorly permeable Checkerboard Limestone, which is at the base of the Coffeyville Formation in the Skiatook Group or with the Checkerboard Limestone in the Skiatook Group. Additionally, no-flow boundaries were used at the edge of the active model area for all layers (fig. 5). The groundwater divides (groundwater basins or catchment areas) were assumed to be the same as the surface-water divides
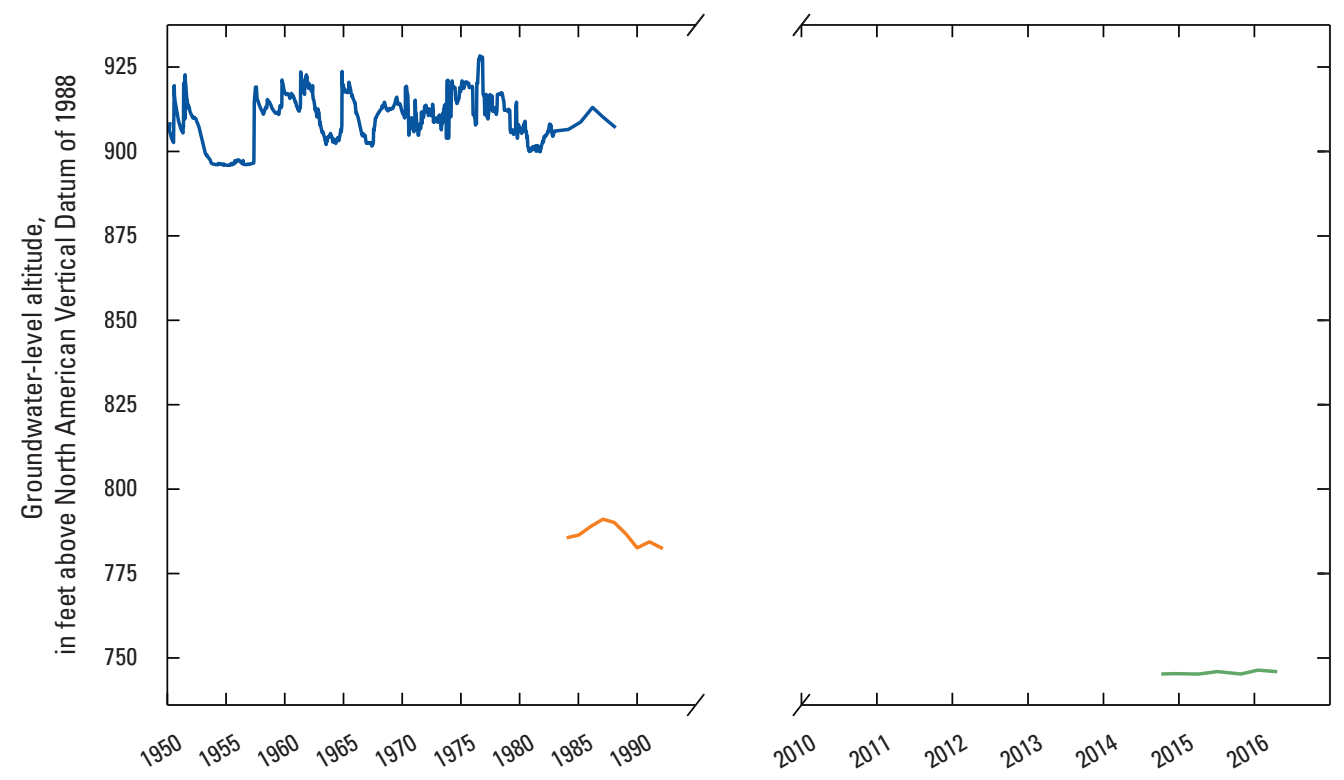

EXPLANATION

U.S. Geological Survey observation wells (U.S. Geological Survey, 2016)

Date of measurement

Figure 6. Groundwater-level hydrograph of U.S. Geological Survey observation wells 364210097025401, 363058096440101, and 363727096143201 (well locations shown on fig. 1) (data available from U.S. Geological Survey, 2016). 
(drainage basin or watershed) because they can be the same when surface-water and groundwater flows are driven predominantly by topographic changes (fig. 2 in Hevesi and others, 2020). Groundwater-flow directions are necessary to delineate areas where groundwater flows in, out, or parallel to the model boundary; however, groundwater-flow directions could not be mapped along the boundary of the study area because of insufficient water-level data. The surface-water boundaries were derived from the PRMS model boundaries, and groundwater boundaries were assumed to be coincident. An irrigation well and four production wells were near the southern boundary of the model (fig. 5), but they did not cause an issue with the simulation because pumping from irrigation and production wells was not a substantial part of the conceptual groundwater budget, therefore these wells were retained in the model.

\section{Landscape Use and Movement of Water}

The MF-OWHM software provided a fully coupled simulation of the interaction between the atmosphere, surfacewater, landscape water, and groundwater-flow components of the water cycle in the study area using a combination of the Farm Process Package (FMP; Hanson and others, 2014; Boyce and others, 2020) and Streamflow Routing Package (SFR; Niswonger and Prudic, 2005). The FMP Package estimated water use as supply and demand, movement, and consumption for agricultural irrigation water and natural vegetation that occurs on the landscape and in the root zone; therefore, the use and movement of water on the landscape and root zone is fully coupled with surface-water and groundwater flow and is dependent on climate inputs of precipitation and PET (fig. 7). At the landscape level, the FMP Package estimated the water demand for each land use and identified and delivered the corresponding supply of water to meet those specific crop water demands (CWDs). Similarly, for natural vegetation, the supply of water through precipitation and direct uptake of groundwater, if the roots reach the water table, was consumed based on the demand of cell-by-cell vegetation defined land use. Water demand for each land use, called CWD, were calculated by multiplying a specified crop coefficient $\left(K_{c}\right)$ by PET for all land-use settings (Boyce and others, 2020). The unsaturated zone from below the root zone to the water table was not simulated in the FMP Package or in MF-OWHM. If necessary, to comply with the conceptual model, the unsaturated zone can be simulated with MF-OWHM using the Unsaturated Zone Flow Package (UZF; Niswonger and others, 2006).

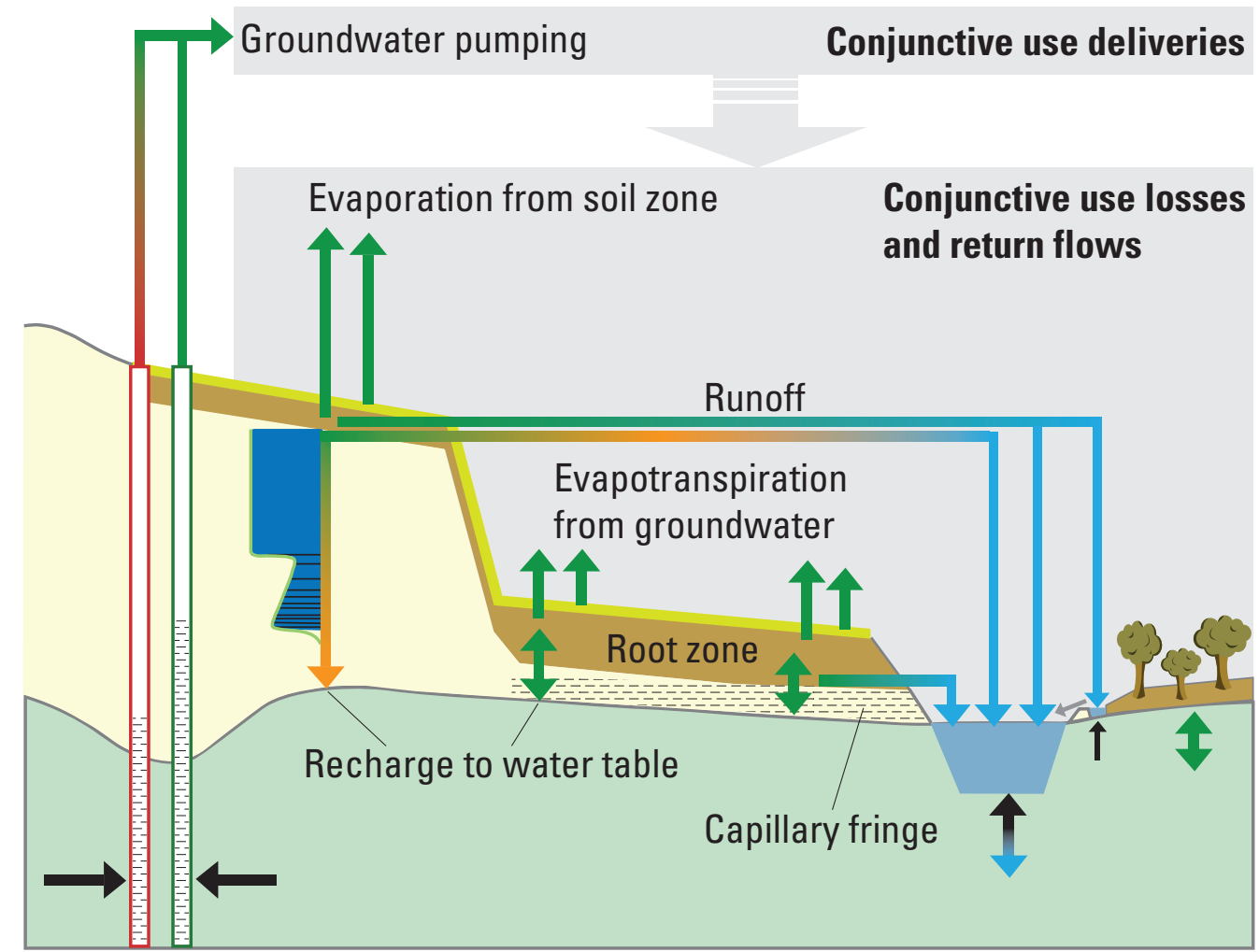

NOT TO SCALE

\section{Conjunctive use losses \\ Streamflow Routing Package}

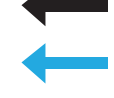

Well Package

Figure 7. Schematic representation of components simulated by the Farm Process Package in the MODFLOW One-Water Hydrologic Model for the Osage Nation Integrated Hydrologic Model (modified from Schmid and Hanson, 2009). 
For agricultural areas of crop irrigation, consumptive use of each irrigated crop type was simulated by estimating the CWD. The FMP Package tried to meet the CWD by supplying water from soil moisture, root uptake from shallow groundwater, and precipitation. If those sources did not meet the CWD, the difference is the crop irrigation requirement, which is then obtained through groundwater pumpage at a specified well and applied to the crop and accounts for irrigation inefficiencies such as evaporation, return flow (recharge), and runoff of applied water. For nonirrigated areas such as native vegetation, the FMP Package estimates the CWD and tries to meet this demand by suppling water from soil moisture, root uptake of shallow groundwater, and precipitation. If the CWD is not met with those sources, then simulated ET is curtailed by an amount associated with the magnitude of the CWD deficit. The precipitation that is not consumed by the plant to meet the CWD is partitioned into runoff, which is then routed to nearby streams or deep percolation that becomes recharge to the water table. Further details on MF-OWHM and the utility of the FMP Package are described in Hanson and others (2014) and Boyce and others (2020). To facilitate CWD, crop irrigation requirement, deep percolation, and runoff calculations, the FMP Package requires input datasets for water-balance subregions (WBSs), climate variables, surface-water flow characteristics, land use, crop type characteristics such as root depth, soil characteristics, fractions of transpiration and evaporation from irrigation and precipitation, sources of groundwater supply for crops, and soil. Each of these inputs are described in the following subsections.

\section{Water-Balance Subregions}

The FMP Package allows the user to delineate multiple zones in the active model domain that act as accounting units for the landscape water budget components. These zones are referred to as water-balance subregions (WBSs). For this study, 128 independent WBSs were delineated based on a combination of surface-water boundaries, dominant land uses, hydrostratigraphic characteristics, and public water supply regions. The area of each WBS ranged from 1,024 to 128,640 acres (1.6 to 201 square miles). The 128 WBSs were combined into larger zones called "supergroups." For this study, 12 supergroups were created from the original 128 WBSs based on larger scale public water supply needs, specific regions of interest to the Osage Nation, and regions of varying water quality (fig. 8, available for download as layers in portable document format [PDF] at https://doi.org/10.3133/ sir20205141). Some WBSs were included in multiple supergroups, and therefore some of the supergroups overlap each other. The supergroups will be used to summarize model results for regions of interest to the Osage Nation.

\section{Climate}

The ONIHM used preexisting gridded precipitation and PET datasets that were developed for the PRMS model to specify the fluxes for each stress period (Hevesi and others,
2020). Precipitation and PET grids were specified in the FMP Package as an average daily rate, and the MF-OWHM then calculated the total flux of precipitation or PET for each stress period by multiplying the average daily rate by the number of days in the corresponding stress period.

\section{Surface-Water Flow Characteristics}

Surface-water inflows, routing, and outflows were simulated using the SFR Package (Niswonger and Prudic, 2005) with a streamflow routing network consisting of 237 stream segments and 3,728 reaches or cells representing the perennial reaches of the Arkansas River, Bird Creek, Caney River, Hominy Creek, Salt Creek, Sand Creek, and their tributaries (fig. 5). Perennial stream reaches were selected for segments in the National Hydrography Dataset coded as perennial reaches (U.S. Geological Survey, 2013). The SFR Package is a head-dependent boundary condition that simulates streamflow routing and the conveyance of overland runoff, groundwater discharge (gaining stream reaches), and streamflow infiltration into the aquifer (losing stream reaches). The streambed elevations for the beginning and end of each segment were specified using a DEM to ensure that water flowed "downhill” across each stream segment (U.S. Geological Survey, 2015). Data were not available to determine the streambed thickness; therefore, a uniform value of $3.3 \mathrm{ft}$ was used for all stream reaches. The vertical hydraulic conductivity of reaches within each segment was initially specified according to the underlying hydrostratigraphic layer. The streambed roughness coefficient was specified as 0.03 for all stream reaches based on normal values of natural streams (Chow, 1959). Each SFR Package reach was assigned to the uppermost active model layer.

The streamflow routing network was set up with a total of 19 inflow points: 8 of those points were used to specify stream inflows to the model for streams that originated outside the active model domain and the other 11 inflow points were immediately downstream from reservoirs and used to simulate reservoir releases to the SFR Package from (1) Kaw Lake (Arkansas River), (2) Skiatook Lake (Hominy Creek), (3) Hulah Lake (Caney River), (4) Avant Lake (Candy Creek) (not shown), (5) Birch Lake (Bird Creek) (not shown), (6) Bluestem Lake (Middle Bird Creek) (not shown), (7) Cleveland Lake (Ranch Creek) (not shown), (8) Sooner Lake (Greasy Creek) (not shown), (9) Lake Ponca (Turkey Creek) (not shown), (10) Waxhoma Lake (Bird Creek) (not shown), and (11) Phillips Lake/Lake Charlotte (Salt Creek) (not shown). Reservoir release data were only available for Kaw Lake, Hulah Lake, Skiatook Lake, and Birch Lake. Releases from the other lakes were specified using PRMS streamflows extracted from PRMS cells immediately downstream from the dams. Inflow values used in the ONIHM were extracted from the coincident PRMS model stream cells immediately upstream from the ONIHM active model boundary (Hevesi and others, 2020). PRMS-simulated streamflows also were extracted and used in the ONIHM for inflow points 


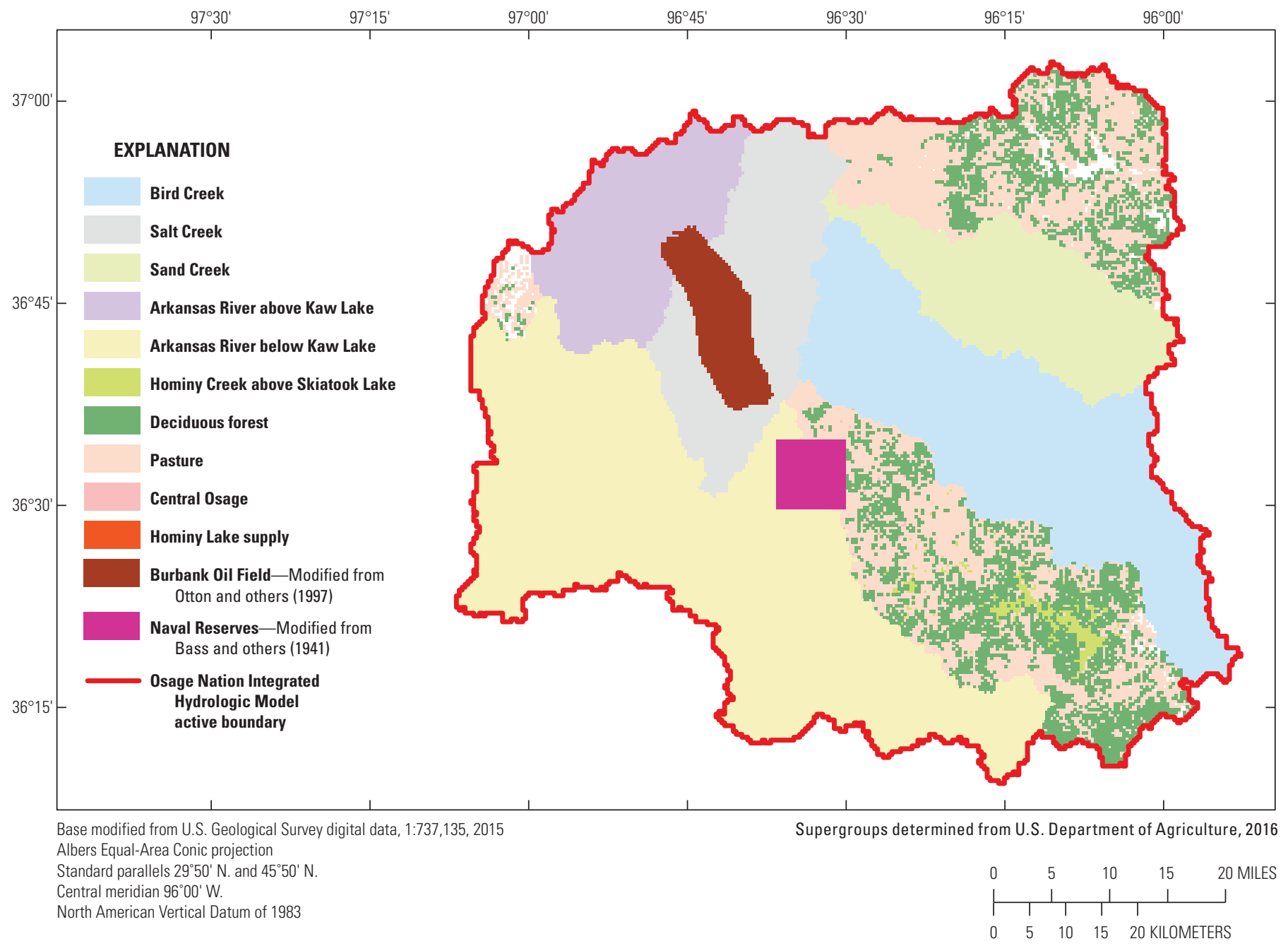

Figure 8. Supergroups for the Osage Nation Integrated Hydrologic Model (note: some supergroups are hidden; in order to see a given supergroup, the reader may need to turn off layers for the overlying supergroups).

downstream from reservoirs before reservoir construction (Hevesi and others, 2020). Mean monthly inflows to the SFR network were largest for the Arkansas River, Kaw Lake reservoir releases, and Salt Fork of the Arkansas River. These inflows were an order of magnitude larger than the next largest inflows. Several smaller lakes (Avant Lake, Ponca Lake, Waxhoma Lake, and Phillips Lake/Lake Charlotte) had zero mean reservoir releases, or inflows to the SFR network, for the simulation period, which was consistent with anecdotal knowledge of the dam operations (Craig Walker, Osage Nation Environmental and Natural Resources Department, oral commun., April 2017; data used in the study are provided in the model archive Traylor and Peterson, 2021). The inflow points at the model boundary were important because they were the primary influx of water from the areas adjacent to the model domain. Reservoir stage and storage were not simulated in the ONIHM.
In the ONIHM, runoff from precipitation was simulated by the FMP Package via partitioning of surplus precipitation, after CWD has been met, into runoff or groundwater recharge. In the FMP Package, this is called the fraction of inefficient losses to surface water from precipitation (FIESWP). The remaining precipitation that has not been consumed by CWD or runoff goes to deep percolation past the root zone that recharges the water table. The FMP Package also partitions surplus irrigation water similarly, which is called the fraction of inefficient losses to surface water from irrigation (FIESWI). The runoff from precipitation and (or) irrigation was routed to the most downstream SFR stream reach (cell) within each WBS via an FMP feature called semirouted return flow. Like excess precipitation, any irrigation water that has not been consumed or partitioned to runoff goes to deep percolation past the root zone that recharges the water table within the same stress period as it occurs. 


\section{Simulated Land Use}

From 1950 to 2005, excluding 1992 and 2001, land use was based on the simulated historical land use and landcover (LULC) datasets developed by Sohl and others (2016). Sohl and others (2016) produced annual LULC datasets that covered the conterminous United States at an 820-ft grid resolution and specified 14 LULC classes. For the ONIHM, the 14 LULC classes were grouped into 10 of the most common LULC classes and resampled to the ONIHM cell size of 1,312.34 ft (fig. 2).

ONIHM land use for 1992 and 2001 was based on the National Land Cover Database (NLCD) (Homer and others, 2015). The NLCD dataset contained growing and nongrowing season datasets, which offered a finer resolution dataset than the annual dataset from Sohl and others (2016). The NLCD datasets contained a 98.42-ft grid resolution with 16 land-use classes. For the ONIHM, the 1992 and 2001 NLCD datasets were resampled to the ONIHM grid size and the 16 land-use classes were combined into the 10 most common classes in the study area.

ONIHM land use for 2006-14 was based on the U.S. Department of Agriculture Crop Data Layer (U.S. Department of Agriculture, 2016). The Cropland Data Layer datasets contained growing season and winter season datasets for each year that specified 31 land-use classes at a 98.4-ft grid resolution. For the ONIHM, the 31 land-use classes were grouped into the 10 most common land-use classes and resampled to the ONIHM 1,312-ft cell size.

The 10 most common land uses simulated in the ONIHM were fallow/idle, pasture, urban, alfalfa, open water, sorghum, soybeans, winter wheat, other crops, and deciduous forest (fig. 2). Land-use grids for each stress period were specified in the FMP Package of MF-OWHM. The two most common land uses in the ONIHM were pasture and deciduous forest. Each land-use name was a specified FMP Package input for MF-OWHM.

\section{Crop-Type Characteristics}

$K_{c}$ values were used in conjunction with PET to calculate the water demand for each land use. Published $K_{c}$ values were specified for all land uses from Allen and others (2005). When exact land uses were not available in the published data, $K_{c}$ values from similar land uses were substituted (for example, apple tree $K_{c}$ values were used for deciduous forest land-use). The ONIHM required $K_{c}$ values specified for each monthly stress period; however, published $K_{c}$ values for all land uses were only defined for three periods: early, mid-, and late growth stages. Therefore, daily $K_{c}$ values were calculated for all crop types by interpolating between common planting dates and growth stage dates published by Sutherland and others (2005) and Allen and others (2005). Monthly $K_{c}$ values were then obtained by averaging the daily $K_{c}$ values for the given month. It was assumed that $K_{c}$ values were dynamic for each monthly stress period but not dynamic annually such that the same $K_{c}$ value was defined for each January from 1950 to
2014, another for each February from 1950 to 2014, and so forth. Plant characteristics such as $K_{c}$ values are inherent plant properties that do not do not change annually or with climate: the annual changes due to climate were represented with PET and PPT datasets.

Additionally, climatic data (National Climatic Data Center, 2016), from Pawhuska, Okla., were used to determine frost dates for season timing. Water temperature maximum and minimum timing was determined from an analysis of published water temperature records for the Arkansas River at Tulsa, Okla., streamgage (USGS station 07164500; U.S. Geological Survey, 2016).

\section{Fractions of Transpiration and Evaporation from Irrigation and Precipitation}

The FMP Package simulated the ratio of crop evaporation and transpiration from irrigation water sources and precipitation to more accurately replicate the natural trend of ET across each stress period of the model. The partitioning of transpiration and evaporation was accomplished by assigning fractional values for both parts of ET, dependent on the water source. If the water source was precipitation, the FMP package required the fraction of transpiration for each crop type. Conversely, if the water source was from irrigation, the FMP Package required the fraction of evaporation for each crop type. The fraction of transpiration is the ratio of the basal crop coefficient $\left(K_{c b}\right)$, from the dual crop-coefficient method for calculating ET in Allen and others (2005), divided by full $K_{c}$ value that represents the fraction of total cropped area covered by the crop canopy (Boyce and others, 2020). For example, during the nongrowing season stress periods when plants were dormant, evaporation was the major contributor to total ET, and conversely, during the peak of the growing season stress periods, when plant transpiration was highest and the leaf-area index was largest, transpiration was the dominant part of ET. The fraction of evaporation from irrigation is the fraction of total cropped area in which irrigated water is applied to bare soil; and is calculated as one minus the fraction of transpiration (Boyce and others, 2020). Therefore, the fraction of evaporation from irrigation was set equal to the fraction of evaporation for each crop type.

\section{Sources of Groundwater Supply for Crops}

Agricultural groundwater pumpage for crop irrigation or livestock water supply was not a substantial water budget component for any WBS in the ONIHM. There were only 29 registered irrigation wells operating by the end of the simulation period (Oklahoma Water Resources Board, 2016). Livestock water supply wells were not included in the ONIHM because of their characteristically low flow rate and subsequent small volume of groundwater pumped when compared to other water budget components. Irrigation efficiency values, called onfarm efficiencies, for all crop types were held constant at 0.85 (85 percent). An irrigation flag file was input 
to the ONIHM, which specified the stress periods when irrigation water from wells should be applied to the crop.

In the ONIHM, only cells that had an irrigation well present were specified as irrigation cells. Construction dates were assumed to be the approximate start date for use and estimated yield values were used to specify the maximum pumping rate for each farm well. The construction dates and yield values were obtained from the Oklahoma Water Resources Board water-use database (Oklahoma Water Resources Board, 2016).
Soils

The soils in the ONIHM were distilled into three categories - sand, loam, and clay - based on data from the Soil Survey Geographic Database (U.S. Department of Agriculture, 2014; fig. 9). The capillary fringe also was estimated for each soil type and the thickness ranged from 0.49 to $1.48 \mathrm{ft}$. These soil attributes were constant for the simulation period, and the cell-by-cell distribution remained independent of the crop type and WBSs. The FMP Package linked the soil types with the capillary fringe data and internal coefficients to facilitate calculation of ET using analytical solutions (Schmid and others, 2006).

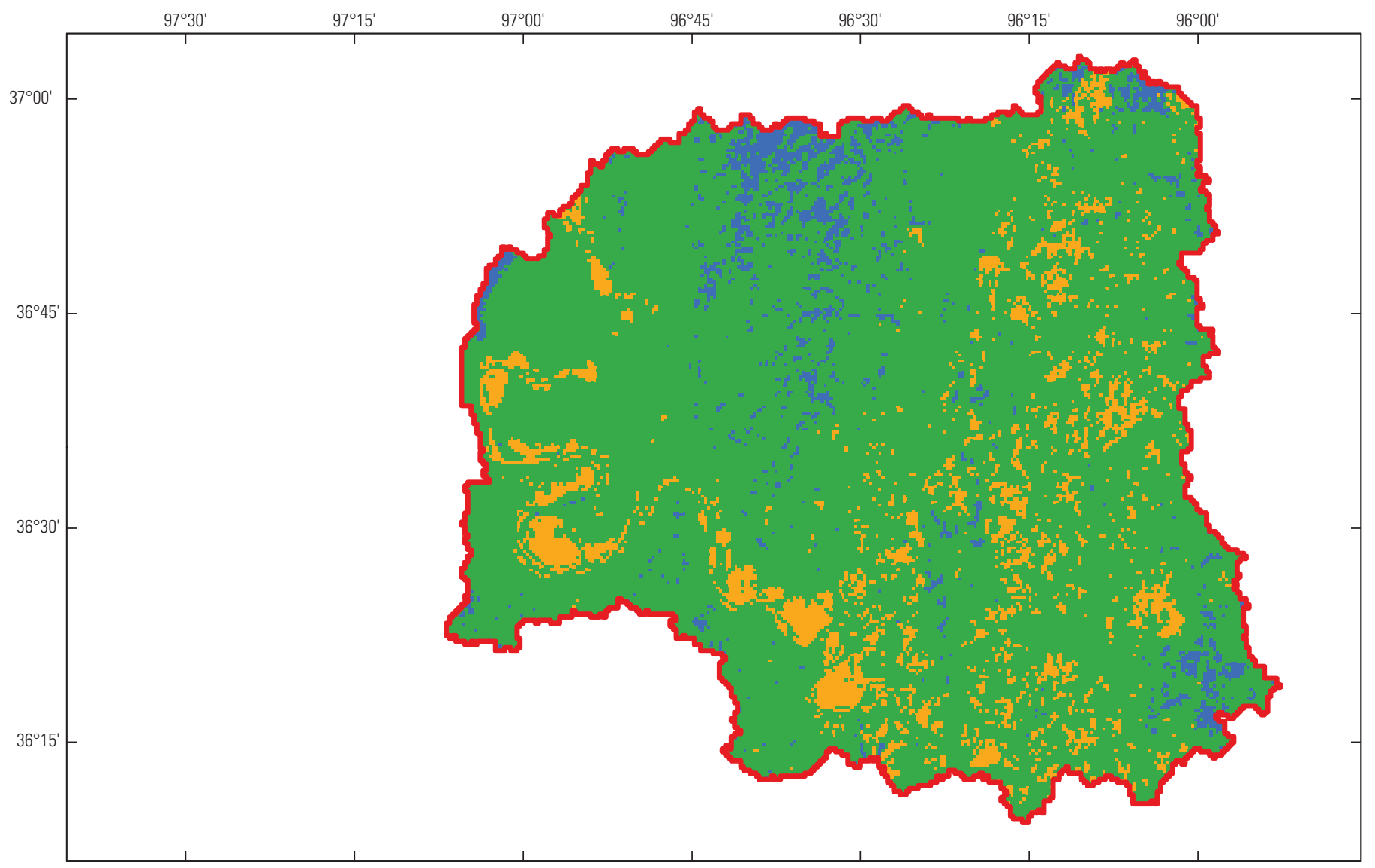

Base modified from U.S. Geological Survey digital data, 1:737,135, 2013 Albers Equal-Area Conic projection

Standard parallels $29^{\circ} 50^{\prime} \mathrm{N}$. and $45^{\circ} 50^{\prime} \mathrm{N}$.

Central meridian $96^{\circ} 00^{\prime} \mathrm{W}$.

North American Vertical Datum of 1983

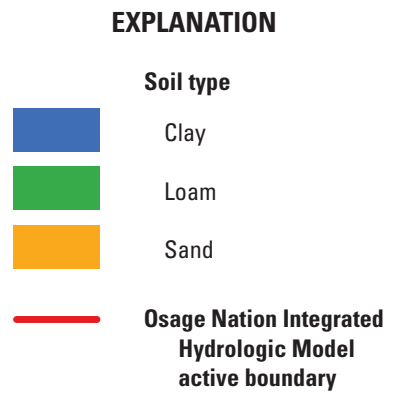

Soil types from U.S. Department of Agriculture, 2014

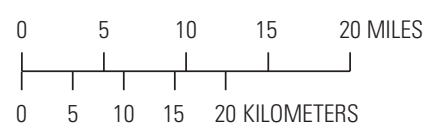

Figure 9. The three soil types used in the Osage Nation Integrated Hydrologic Model (U.S. Department of Agriculture, 2014). 


\section{Groundwater Inflows, Outflows, and Changes in Storage}

The groundwater-flow aspect of the ONIHM was simulated with the 2005 version of the USGS modular threedimensional groundwater model, MODFLOW, packaged in MF-OWHM, and uses the MODFLOW Newton solver (MODFLOW-NWT, ver. 1.1.2; Niswonger and others, 2011). MODFLOW-NWT is intended for solving nonlinear problems related to drying and rewetting of cells in the unconfined groundwater-flow equation. Most cells in the ONIHM were not expected to go dry, but thin unconfined aquifer zones existed, and the use of MODFLOW-NWT prevented dry cells from going inactive during the simulation.

Standard MODFLOW packages such as the Basic Package and the Discretization File were used in the model (Harbaugh and others, 2000). The Basic Package specified the active cells of the orthogonal grid, which included 47,017 of the 79,764 total cells in the grid. The Basic Package also specified starting water levels in active cells for each of the eight model layers using water levels from an earlier prototype of the ONIHM developed in this study. The Discretization File specified the 8 model layers, 276 rows, 289 columns, individual layer elevations for each cell, and the length of each stress period.

The Upstream Weighting Package (Niswonger and others, 2011), a required package for MODFLOW-NWT, specifies properties controlling flow between cells, such as hydraulic conductivity, anisotropy, specific storage, and specific yield. These properties were individually specified for each model layer because there was a lack of available data necessary to define the spatial variation of these properties. Initial hydraulic conductivity, specific yield, and specific storage were set to the estimated values described in the "Aquifer Properties" section. Hydraulic conductivity was assumed to be constant through time and horizontally isotropic but vertically anisotropic and adjusted during calibration. Specific yield was not adjusted during calibration and was also assumed to be constant through time. Vertical anisotropy for all layers was defined as the ratio of horizontal to vertical hydraulic conductivity. Similarly, specific storage was set to estimated values described in the "Aquifer Properties" section and was not adjusted during calibration and was assumed to be constant through time.

The Well Package (Harbaugh and others, 2000) was used to simulate groundwater withdrawals from high capacity wells for production and industrial use. Well registration and water-use permit records obtained from the Oklahoma Water Resources Board water-use database (Oklahoma Water Resources Board, 2016) were matched to determine water use within each model cell (fig. 4; Traylor and Peterson, 2021). Missing data were estimated using interpolation when possible and following county-level population trends otherwise (U.S. Census Bureau, 2003, 2017). Groundwater withdrawals for irrigation wells was simulated by the FMP package (see "Sources of Groundwater Supply for Crops" section). Groundwater withdrawals from domestic, livestock, commercial, and other unmentioned types of wells were not simulated in the ONIHM because their combined total groundwater withdrawals were assumed to be negligible.

Simulated water levels and streamflows were output to separate files for analysis. The MODFLOW Gage Package (Niswonger and Prudic, 2005) was used to output simulated streamflows at target locations. The Parameter Estimation software (PEST) utility, mod2obs.exe (Doherty, 2009), was used to extract simulated water levels for comparison with calibration targets.

\section{Integrated Hydrologic Model Calibration Approach}

The automated model calibration process of the ONIHM used the automated PEST software (Doherty, 2016). A common theme in numerical hydrologic-flow modeling efforts is the specification of model inputs like aquifer properties, hydrostratigraphic layer altitudes, land-use characteristics, and other inputs that vary across space and time. Model outputs, such as streamflows and water levels, are compared to space and time equivalent measured values - a process described in the "Calibration Targets" section of the report. Typically, these initial outputs do not adequately match the calibration targets. To improve the fit between measured and simulated calibration targets, a select number of specified input parameters are adjusted in a process called "calibration."

Calibration of the ONIHM using PEST first involved initial "expert interaction" and adjustment of the specified input parameters throughout the development of the model, that is, parameters were adjusted manually to improve the fit between observation targets and their simulated equivalent values. The final set of input parameter values obtained from the manual calibration was set as the initial input parameter values for the automated PEST calibration. Automated PEST calibration was facilitated by a parallel computing version of PEST called BEOPEST (Hunt and others, 2010) and deployed on a cluster of machines via the open source, high throughput, workload management software HTCondor (Condor Team, 2012).

\section{Calibration Targets}

The ONIHM was calibrated to minimize the objective function $(\Phi)$, which is the sum of squared weighted residuals between measured observations and simulated equivalent outputs (Doherty, 2016) calculated using the following equation:

$$
\Phi=\sum_{i=0}^{n}\left(w_{i} r_{i}\right)^{2}
$$


where

$n \quad$ is the number of observations,

$i \quad$ is the observation number,

$w \quad$ is the weight applied to the observation, and

$r \quad$ is the residual between time and space-

equivalent measured and simulated values.

Calibration targets are measured or estimated hydrologic data assumed to represent conditions of the hydrologic system at the time of their measurement. A time series of calibration targets is assumed to represent the temporal behavior of the hydrologic system. PEST allows calibration targets to be clustered into groups where each group's contribution to the $\Phi$ can be assessed. In the ONIHM, calibration targets were grouped together based on data type and data source. The ONIHM had the following observation groups specified in PEST (table 4): measured total streamflows from USGS streamgages ( $\mathrm{dev}$ flux; U.S. Geological Survey, 2016), simulated streamflows extracted from the PRMS model (devfluxprms; Hevesi and others, 2020), measured streamflows from the Osage Nation Environmental and Natural Resources Department (devfluxenr; Craig Walker, Osage Nation Environmental and Natural Resources Department, written commun., April 2017; data used in the study are provided in the model archive, Traylor and Peterson, 2021), monthly differences in streamflow from the USGS streamgages (flowchng; U.S. Geological Survey, 2016), monthly differences in streamflow from the simulated PRMS model streamflows (flowchngprms; Hevesi and others, 2020), groundwater-level altitudes above land surface at each model cell (lswlck), measured water levels (measdevwl; Oklahoma Water Resources Board, 2016; U.S. Geological Survey, 2016), estimated water levels (estdevwl), and measured water levels from a groundwater synoptic survey in November and December 2014 (syndevwl; U.S. Geological Survey, 2016; table 4). The most important target groups to the calibration were the devflux, flowchng, flowchngprms, and measdevwl groups.

Error-based weighting of the calibration targets was applied to each target based on measurement uncertainty associated with each measurement type (Hill and Tiedeman, 2007). Error-based weighting also kept PEST from being overinfluenced by targets with the largest magnitudes and different units. PEST's attempts to minimize the $\Phi$ are affected by the number and magnitude of the targets in each observation group such that groups with higher magnitudes or a greater number of targets have more effect on the $\Phi$ than groups with smaller or fewer targets. For example, a streamflow target of $41 \mathrm{ft}^{3} / \mathrm{s}$ (about 3,460,000 cubic feet per day) is four orders of magnitude larger than a water level of $984 \mathrm{ft}$, and when

Table 4. Streamflow and groundwater-level calibration target counts and data description and source by Parameter Estimation software (PEST) observation group.

[NAVD 88, North American Vertical Datum of 1988; NA, not applicable; USGS, U.S. Geological Survey; PRMS, Precipitation Runoff Modeling System; ENR, Osage Nation Environmental and Natural Resources Department; OWRB, Oklahoma Water Resources Board groundwater database]

\begin{tabular}{|c|c|c|c|c|}
\hline $\begin{array}{l}\text { Observation } \\
\text { group }\end{array}$ & Count & $\begin{array}{l}\text { Mean streamflow, } \\
\text { in cubic feet } \\
\text { per second }\end{array}$ & $\begin{array}{c}\text { Mean groundwater } \\
\text { altitude, } \\
\text { in feet above NAVD } 88\end{array}$ & Data source \\
\hline \multicolumn{5}{|c|}{ Streamflow calibration targets } \\
\hline devflux & 5,307 & 2,350 & NA & Measured streamflows from USGS streamgages (USGS, 2016). \\
\hline devfluxprms & 8,679 & 871 & NA & PRMS simulated flows from Hevesi and others (2020). \\
\hline flowchng & 4,341 & 0 & NA & Calculated using USGS streamflows (USGS, 2016). \\
\hline devfluxenr & 142 & 6 & NA & $\begin{array}{l}\text { Measured streamflows from ENR (Osage Nation Environmental and } \\
\text { Natural Resources Department, written commun., April 2017). }\end{array}$ \\
\hline \multicolumn{5}{|c|}{ Groundwater-level altitude calibration targets } \\
\hline measdevwl & 713 & NA & 849 & $\begin{array}{l}\text { Measured groundwater levels (Oklahoma Water Resources Board, } \\
\text { 2016; USGS, 2016). }\end{array}$ \\
\hline lswlck & 47,017 & NA & 0 & $\begin{array}{l}\text { Comparison of land-surface altitude and the groundwater altitude } \\
\text { for each model cell. }\end{array}$ \\
\hline syndevwl & 71 & NA & 843 & $\begin{array}{l}\text { Measured groundwater levels from a synoptic survey in November } \\
\text { and December } 2014 \text { (USGS, 2016). }\end{array}$ \\
\hline
\end{tabular}


weighted equally, PEST would be more affected by the streamflow target and become insensitive to the hydrologic signal represented by the water level. Error-based weights for each observation were calculated using the following equation:

$$
w=\frac{1}{\sigma}
$$

where

$w \quad$ is the error-based weight applied to the observation, and

$\sigma \quad$ is the measurement uncertainty of the observation.

Measurement uncertainty varied by observation target group. The measured streamflows from USGS streamgages and changes in streamflow from USGS streamgages were assigned an uncertainty of 5 percent, which correlates to the 95-percent confidence interval that is typical for "good" rated USGS streamgage measurements (U.S. Geological Survey, 2016). PRMS-simulated streamflows and changes in PRMS-simulated streamflows were assigned an uncertainty of 5 percent plus the percentage of average estimated error from Hevesi and others (2020). Osage Nation Environmental and Natural Resources Department-measured streamflows were assigned an uncertainty of 100 percent because these were typically only one manual measurement per month at a given location. Measured water-level observations were assigned an uncertainty of $10 \mathrm{ft}$, which is a general error for land-surface altitude measurements from the global positioning system. Land-surface altitude observations, synoptic water-level measurements, and the estimated development period water levels were assigned an uncertainty of $20 \mathrm{ft}$. Land-surface altitude uncertainty reflects the error in resampling a $32.8-\mathrm{ft}$ DEM dataset to the ONIHM cell size of 1,312.34 ft. Synoptic water-level uncertainty reflects the error in using measurements that were made outside of the simulated model timeframe. The synoptic water-level survey occurred in November and December 2014 (U.S. Geological Survey, 2016) and the ONIHM only simulated to September 2014; however, water levels in most of the study area were stable for the model period of 1950 to 2014 , so it was reasonable to assume that water levels measured 2 months after the end of the simulation time were still reasonable values to use in the calibration. Estimated water-level uncertainty reflects the error in using averaged water levels instead of actual measured water levels. Like the synoptic water levels, it was appropriate to use estimated water levels in the absence of measured water levels because hydrographs and earlier model runs indicated that water levels were stable for the simulation period. To avoid the overinfluence of some calibration targets, the observation weights were adjusted by increasing the weights of the measured streamflows, streamflow changes, and water levels so that PEST would prioritize a reduction in the $\Phi$ for the measured targets over the estimated targets.

\section{Groundwater Levels}

The ONIHM included 713 water-level observations used for calibration targets measured from a total of 196 wells in the study area (fig. 10; Oklahoma Water Resources Board, 2016; U.S. Geological Survey, 2016). The wells with calibration targets were concentrated mostly in the alluvial aquifer, Vamoosa-Ada aquifer, and the minor Pennsylvanian bedrock aquifers (layers 1, 2, and 7 of the ONIHM) (measdevwl observation group). There were 164 wells ( 84 percent) that included only 1 water-level measurement for a single stress period. To compensate for the lack of measured water-level targets, "estimated" water levels for each well were included as observation targets and derived from the average of all measured water levels at each well. These estimated water levels were grouped separately and weighted lower in PEST (estdevwl observation group) because they represented an approximate condition of the hydrologic system rather than a traditional measurement and therefore possessed greater measurement uncertainty. During the study, an attempt was made to measure many water levels across the study area at the same time, referred to as a "groundwater-level synoptic survey." The synoptic survey measured 71 wells (syndevwl observation group) during November and December 2014 (U.S. Geological Survey, 2016), which was after the end of the simulation period for the ONIHM. Because hydrograph analysis of previously measured water levels indicated that there was little water-level change from year to year, inclusion of the synoptic water levels measured only 2 to 3 months after the end of the simulation period was assumed to be appropriate. However, to account for the uncertainty associated with measurements that occurred outside the simulation period (20-ft uncertainty compared to $10-\mathrm{ft}$ uncertainty for measurements inside the simulation period), the synoptic water levels were grouped separately, and lower weights were applied. For wells with more than one measured water level per month, the water level closest to the end of the month was selected as a calibration target. Selection of the water level closest to the end of the month was appropriate because the ONIHM simulated water levels for each stress period that represented the response to stresses throughout the stress period. Therefore, the simulated water levels were the result of hydrologic stresses that occurred over the 1-month stress period.

\section{Streamflows}

The ONIHM included 14,128 streamflow calibration targets. There were 5,307 streamflow measurements from 13 USGS streamgages measured between January 1, 1950, and September 30, 2014 (devflux observation group); 8,679 PRMS simulated streamflows for 11 streamgages (devfluxprms observation group), and 142 discrete streamflow measurements from 5 Osage Nation Environmental and Natural Resources Department streamgages (devfluxenr observation group; data used in the study are provided in the model archive, Traylor and Peterson, 2021) (fig. 10). A measurement uncertainty of 


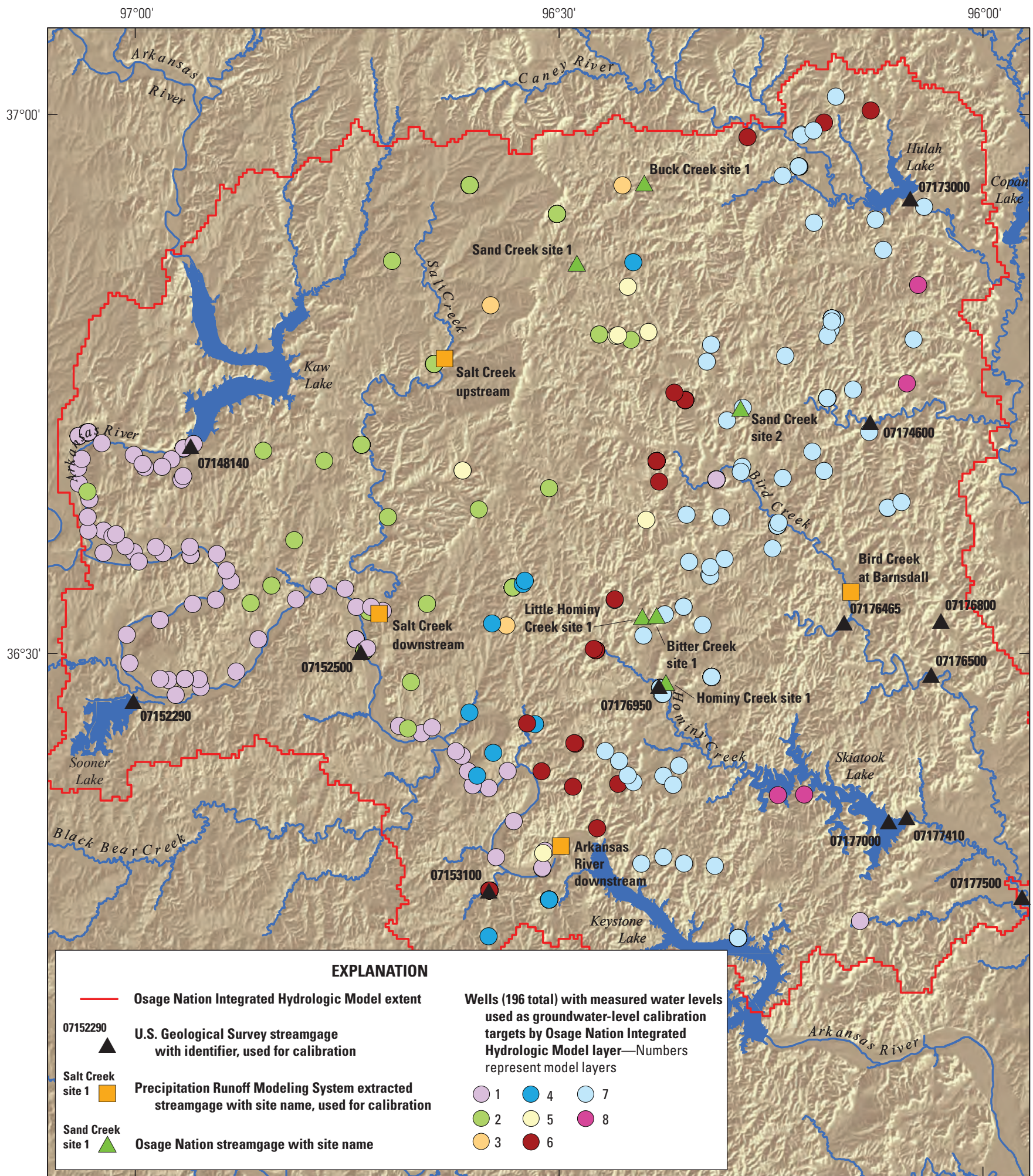

Base modified from Osage Nation Environmental and Natural Resources Department (2017)

North American Vertical Datum of 1983

\begin{tabular}{ccccccc}
0 & & 5 & 10 & 15 & 20 MILES \\
\hline & 1 & 1 & 1 & 1 & 1 & 1 \\
0 & 5 & 10 & 15 & 20 KILOMETERS
\end{tabular}

Figure 10. Wells and streamgages used for calibration targets by the Osage Nation Integrated Hydrologic Model from January 1950 to September 2014. 
5 percent of mean streamflow for the period of record was assumed for the USGS streamgages to calculate weights of each observation target. Some USGS streamgages did not have a streamflow measurement for every stress period of the simulation. Additionally, some important streams and stream reaches did not have a streamgage to record streamflows at any time during the simulation period. Therefore, simulated streamflows from the PRMS model were extracted at cells coincident with the locations of streamgages or stream reaches of interest and included as calibration targets. There were 8,679 PRMS streamflows extracted from 10 locations that had a USGS streamgage during the simulation period and 4 locations that were not gaged or monitored during the simulation period (fig. 10). There is an associated uncertainty when using a simulated streamflow as a calibration target, which was accounted for in PEST by decreasing weights of these simulated PRMS streamflows. Weights for the PRMS-simulated streamflow were calculated as one divided by the sum of streamgage uncertainty (5 percent) and PRMS percentage of average estimation error from Hevesi and others (2020). A total of 142 streamflow measurements were measured by the Osage Nation Environmental and Natural Resources Department at 5 locations (Osage Nation Environmental and Natural Resources Department, written commun., April 2017; fig. 10; Traylor and Peterson, 2021). These data were included in the model because the measurements were taken for stream reaches not represented by the previously mentioned datasets and gave PEST a target to compare simulated values from the ONIHM. These data were assumed to have the most uncertainty because generally only one streamflow measurement was recorded for each month, and it represented only a snapshot of the streamflow conditions even on the day it was collected.

The ONIHM also included a total of 9,162 streamflow change calibration targets. There were 3,305 streamflow change calibration targets calculated from measured streamflows (flowchng observation group) and 5,857 calculated from PRMS-simulated streamflows (flowchngprms observation group). Streamflow change calibration targets were calculated as the difference in streamflow between two consecutive stress periods at a single location. Streamflow change targets were implemented to enable PEST to calibrate the model more accurately to streamflow trends observed between different stress periods.

\section{PEST Calibration Parameters}

A total of 231 parameters in 5 parameter groups were specified and adjusted during calibration to reduce the difference between the calibration targets and their simulated equivalents. Parameters are variables internal to a numerical model whose values can be estimated from hydrologic data. PEST only adjusted parameters during calibration. In numerical hydrologic models such as the ONIHM, parameters typically represent various hydrologic properties such as horizontal and (or) vertical hydraulic conductivity, runoff ratios, and so forth. Parameters also can include scale factors or multipliers that indirectly increase or decrease model inputs such as precipitation or PET: the ONIHM includes parameters of hydrologic properties and scale factors of other model inputs. Parameters are specified in a model because data never exist at the spatial or temporal resolution of a numerical model to accurately assign hydrologic properties to every cell for every stress period. PEST requires parameters to be assigned to groups, therefore the ONIHM parameters were assigned to 5 groups (Doherty, 2016): the groups of parameters were pilot points, which are surrogate parameters at which $K h$ values are estimated and adjusted during calibration and then interpolated across the model grid (pilotpts; 156 parameters), described in the "Horizontal Hydraulic Conductivity Estimated at Pilot Points" section; aquifer properties (aqprops; 24 parameters); stream properties (sfrprops; 8 parameters); landscape and soil properties (farmprops; 31 parameters); and climate properties (climprops; 12 parameters). An upper and lower bound was specified for each parameter to constrain PEST; realistic published values were used as lower and upper limits when available.

Initial parameter values at the beginning of the automated calibration phase were derived from a combination of local knowledge of the study area, information accrued from other scientific investigations of the study area or similar hydrologic settings, and information gained about the ONIHM during the manual calibration phase. To honor these initial parameter values and their information and to keep PEST from deviating too far from the initial values, Tikhonov regularization was applied during the automated calibration (Doherty and Hunt, 2010). Tikhonov regularization imposes a penalty on the $\Phi$ when PEST deviates parameter values from their user-specified initial values. As a result, PEST is affected by the initial parameter values and will only deviate from the initial parameter values if the reduction in the $\Phi$ is larger than the deviation penalty imposed on the $\Phi$. Additionally, the automated calibration was facilitated by the use of the singular-value decomposition-assist feature of PEST where the 231 individual parameters were grouped into 40 "superparameters." The singular-value decomposition-assist feature used the individual parameter sensitivities to identify groups of parameters that were most sensitive to the observations. PEST requires one model run per parameter during the calibration process to assess the effect of individual parameters on the $\Phi$. Therefore, the singular-value decomposition-assist feature facilitates the automated calibration process by reducing the number of parameters necessary for PEST to change during calibration, as well as eliminating unnecessary model runs for parameters that do not improve the calibration.

\section{Horizontal Hydraulic Conductivity Estimated at Pilot Points}

$K h$ parameters were specified at a total of 156 pilot points across all 8 model layers. $K h$ was adjusted by PEST only at these pilot points and then interpolated for cells between the 
pilot points using a utility called fac2real (Doherty, 2009). Fac2real uses the interpolation to produce grids of $K h$ that the ONIHM uses to assign $K h$ for each active model cell. The layer 1 distribution of pilot points was dictated by the discontinuous nature of the layer with 42 of the 49 pilot points specified in the larger western section and 7 pilot points specified within the smaller eastern sections. Pilot points were evenly distributed across model layers 2-8 to avoid spatial bias of the calibration results within layers. The number of pilot points per layer ranged from 12 to 19 (fig. 11). Initial values were assigned to each pilot point in accordance with the hydraulic conductivity associated with each hydrostratigraphic layer identified in the "Aquifer Properties" section of this report. Upper and lower bounds of $K h$ at each pilot point were specified based on reasonable ranges of values from Domenico and Schwartz (1990) and Mashburn (2003).

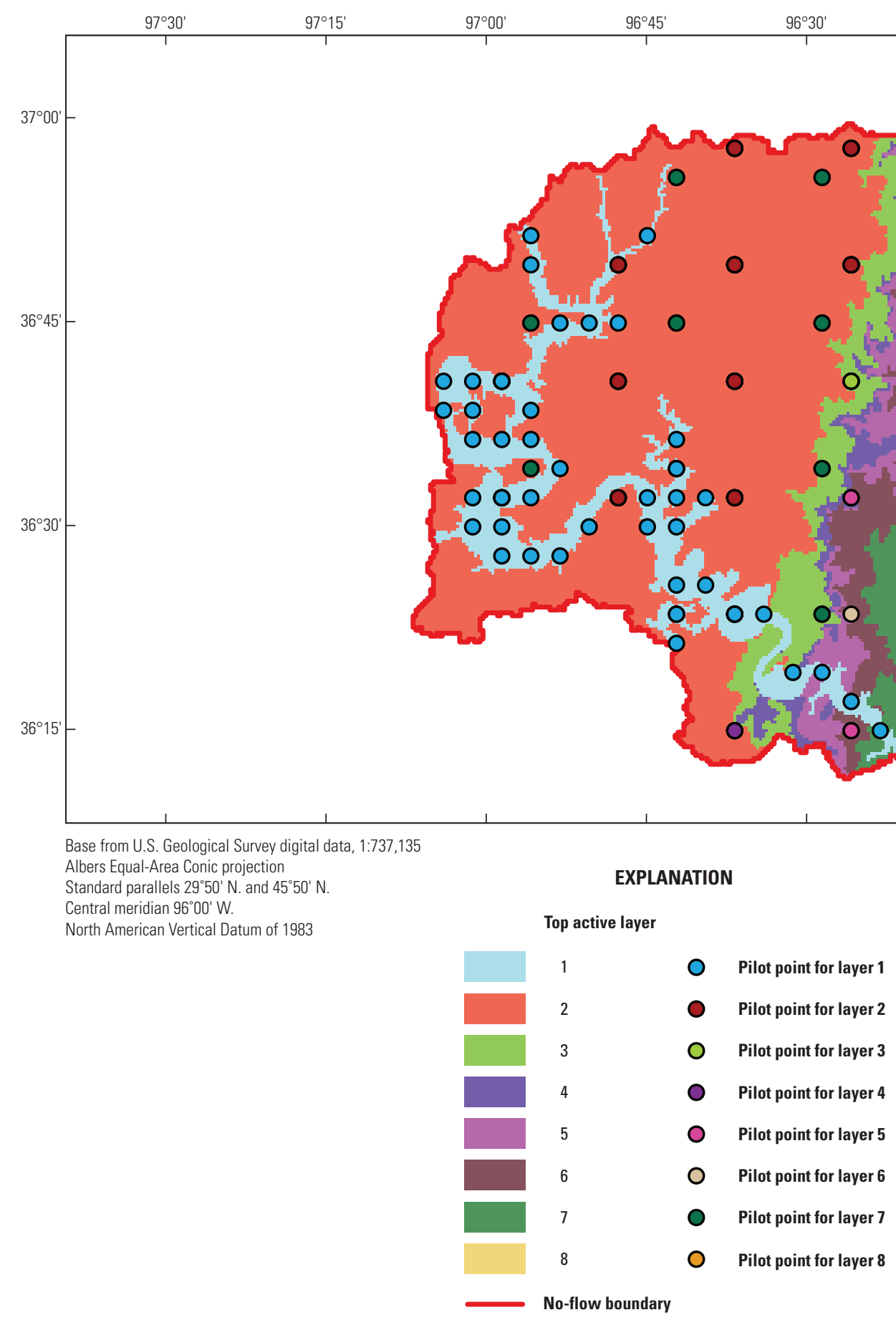

Figure 11. Locations of pilot points by model layer for the Osage Nation Integrated Hydrologic Model active area/boundary (not all pilot points are visible for each layer because they are covered by overlying model layers). 


\section{Vertical Anisotropy}

A total of 8 vertical anisotropy parameters were estimated as the ratio of horizontal to vertical hydraulic conductivity with 1 parameter estimated for each of the 8 model layers. Initial values were assigned to each vertical anisotropy parameter in accordance with the horizontal and vertical hydraulic conductivity associated with each hydrostratigraphic layer identified in the "Aquifer Properties" section of this report. Upper and lower bounds of vertical hydraulic conductivity were based on reasonable ranges of values from Domenico and Schwartz (1990), Mashburn (2003), and Ellis and others (2017). Model layer 1 initial vertical anisotropy was set at 1:1. For layers 2 through 8 , after manual trial and error testing of the model before automated calibration, the model worked better with anisotropy values of 10:1, which indicated that there may be more flow between layers because of vertical fractures in the formations than indicated by reported estimates of 10,000:1 or 1,000:1 (Shana Mashburn, USGS, oral commun., 2017). Therefore, initial values of anisotropy for the automated calibration were set at 10:1 for layers 2 through 8 .

\section{Aquifer Storage Properties}

For each layer of the model, 1 specific storage $\left(S_{s}\right)$ and 1 specific yield $\left(S_{y}\right)$ parameter were estimated for a total of $8 S_{s}$ and $8 S_{y}$ parameters. $S_{s}$ and $S_{y}$ were held constant for all stress periods and only varied from layer to layer. Initial values were assigned in accordance with the values associated with each hydrostratigraphic layer identified in the "Aquifer Properties" section. Upper and lower bounds of $S_{s}$ and $S_{y}$ were based on reasonable ranges of values from Domenico and Schwartz (1990), Mashburn (2003), and Ellis and others (2017).

\section{Streambed Vertical Hydraulic Conductivity}

$K s b$ values were assigned for 8 parameters in accordance with the hydrostratigraphic properties of the top active model layer at each of the 237 SFR segments. Measured data were unavailable for quantifying $K s b$ values in the study area; therefore, it was assumed that $K s b$ was related to hydraulic conductivity characteristics of the model layer within the SFR reach. Field reconnaissance by the authors also verified that several streams cut through the soil layer and flowed directly over the bedrock (fig. 12). Initial values of $K s b$ for calibration were not set to be identical to the vertical hydraulic conductivity of each layer because manual trial and error testing of the model before calibration yielded better results when $K s b$ was not equal to vertical hydraulic conductivity. Therefore, the $K s b$ values were not linked to $K v$ during calibration as "tied" parameters.

\section{Farm Process Calibration Parameters}

Climate and landscape inputs in the FMP Package were specified as parameters and subsequently adjusted by PEST during model calibration to increase the goodness of fit between measured calibration targets and their simulated equivalents. Climate input parameters adjusted during model calibration included scale factors for PET. Landscape input parameters adjusted during model calibration were root depths and fraction of inefficient losses to surface water from precipitation and irrigation water sources.

\section{Root Depth}

A total of 10 root depths were estimated, 1 parameter for each land use, in the ONIHM. Initial values and upper and lower boundary values were selected based on published values for most land uses. Pasture root depth was assumed to be a generalized value because there is more than one native grass present in the study area; however, a common type of native grass was Andropogon gerardii (big bluestem) (field reconnaissance by the authors). Published values of big bluestem root depths ranged from 3.28 to $6.56 \mathrm{ft}$ (Weaver, 1968; U.S. Department of Agriculture, 2004). Like the pasture landuse class, root depths for the deciduous forest land-use class were generalized values because more than one species of deciduous tree existed in the study area. Common deciduous tree species in the study area included Quercus marilandica (blackjack oak) and Quercus stellata (post oak) (field reconnaissance by the authors). Published root depths for these trees were unavailable; therefore, general oak tree values of $16.4 \mathrm{ft}$ were used as upper boundaries because blackjack and post oak are generally much smaller than Quercus alba (traditional white oak) and Quercus rubra (northern red oak), and it was assumed that they also had shorter root systems (Canadell and others, 1996).

\section{Fraction of Inefficient Losses to Surface Water from Precipitation}

A total of 10 FIESWP parameters were estimated-one parameter for each land use. The parameter names are fieswp1, fieswp 2, fieswp 3, fieswp 4, fieswp 5, fieswp6, fieswp 7, fieswp8, fieswp9, and fieswp 10; each suffix number corresponds to the land-use identifier (table 8). Data were not available for these parameters because partitioning of runoff and recharge is dependent on many factors; therefore, general conceptual model magnitudes of precipitation, ET, and recharge were used to estimate a reasonable initial value. Hevesi and others (2020) estimated that ET was about 70 percent of annual precipitation and after ET is removed from precipitation, about 90 percent of the remaining annual precipitation is available for runoff. Annual recharge that arrived at the water table was assumed to be about 8.2 percent of annual precipitation. Therefore, the initial FIESWP value was set at 0.9 (90 percent) for 9 out of 10 parameters except for open water, which was assumed to have almost all runoff go to a surface water feature and was consequently set at 0.999 . FIESWP cannot exceed 1.0 because it is a fraction; therefore, the upper bound was set to 1.0 for all land use and the lower bound was set to 0.2 because due to the high runoff potential it was unlikely that such as low fraction of precipitation would constitute runoff. 


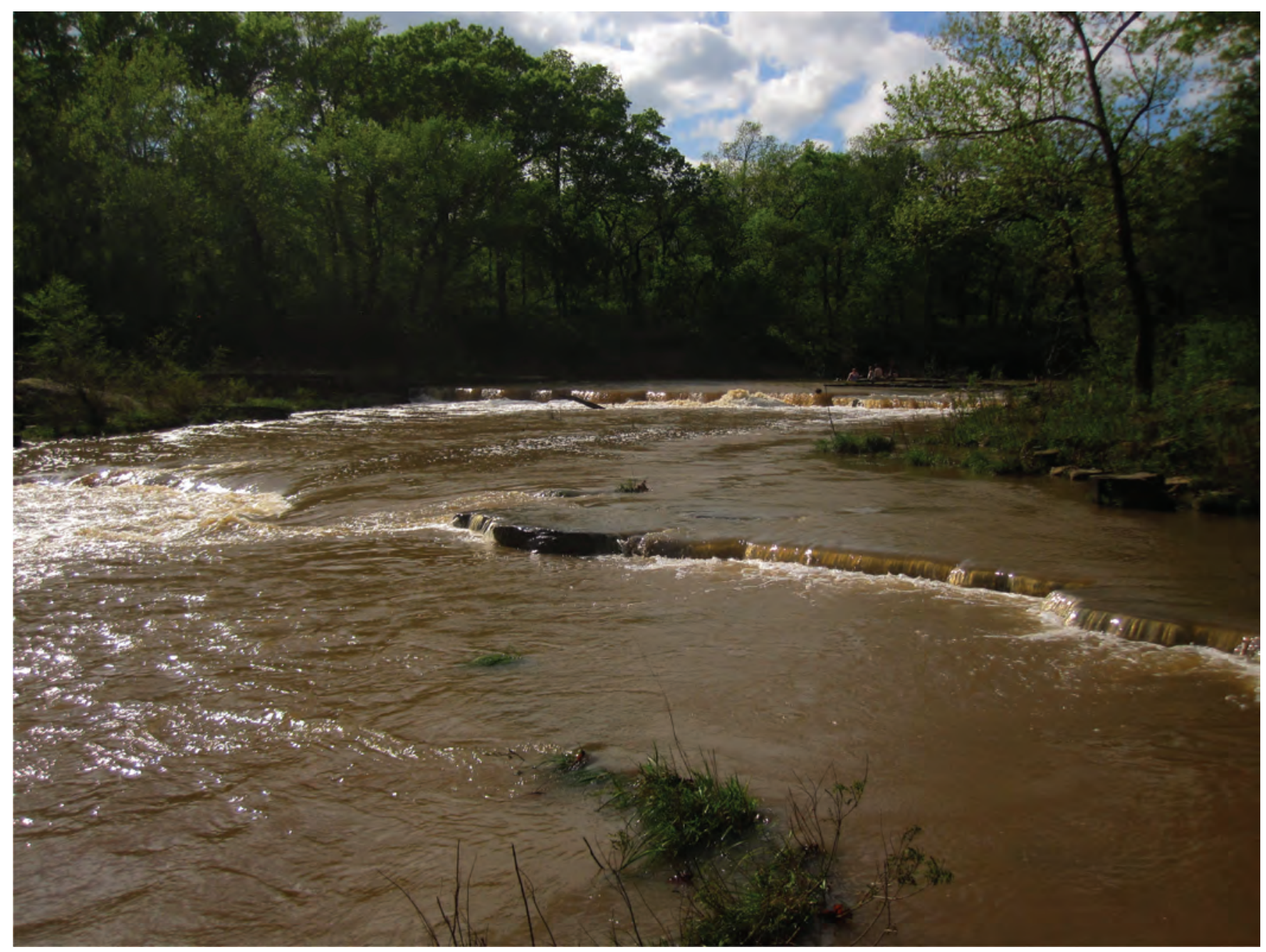

Figure 12. Sand Creek in Osage Hills State Park, Oklahoma, showing a bedrock streambed.

A scale factor was applied to FIESWP for stress periods with precipitation amounts that exceed the 75 th percentile. It was assumed that FIESWP increased during these extremely high precipitation months; therefore, a scale factor on FIESWP greater than 1.0 would increase runoff from precipitation. Initial values were set to 1.05 and lower and upper bounds were set to 0.7 and 1.5 , respectively.

\section{Fraction of Inefficient Losses to Surface Water from Irrigation}

A total of 10 parameters were estimated for FIESWIone for each land use. The parameter names are fieswil, fieswi2, fieswi3, fieswi4, fieswi5, fieswi6, fieswi 7, fieswi8, fieswi 9 , and fieswil0; each suffix number corresponds to the land-use identifier (table 8). Like FIESWP, these parameters represent a generalized process that is affected by many factors. Additionally, data for these parameters were not available, so it was assumed that little irrigation water runs off the field to which it was applied. Therefore, initial values ranged from 0.001 to 0.1 for all land uses except open water and fallow, which are never irrigated. FIESWI could not exceed 1.0; therefore, the upper limit was specified as 1.0 and the lower limit was set at 0.001 .

\section{Scale Factors for Potential Evapotranspiration}

Monthly scale factors were applied to the PRMSsimulated PET grids to better match the monthly trend in the observed monthly average PET from five Mesonet stations in the OHIHM active domain (see fig. 21 in Hevesi and others, 2020). The PRMS-simulated PET grids were calibrated to PET measurements at 14 Mesonet stations, described in Hevesi and others (2020). Scale factors were necessary because the difference between measured and simulated monthly average PET demonstrated a positive trend (PRMS underestimated PET) from August to April and a negative trend (PRMS overestimated) from May to July. Initial values for the calibration were calculated using the following equation: 


$$
\operatorname{SFAC}_{P E T}(i)=1+\left(\frac{P E T_{\text {observed }}^{\text {avg }}(i)-P E T_{P R M S}^{\text {avg }}(i)}{P E T_{P R M S}^{\text {avg }}(i)}\right)
$$

where

$$
\begin{aligned}
S_{F A C_{P E T}} & \begin{array}{l}
\text { is the monthly scale factor of PET; } \\
\text { is the observed monthly average PET at the } \\
\text { five Mesonet stations, in inches; }
\end{array} \\
i & \begin{array}{l}
\text { is the month; and } \\
\text { iverved }
\end{array} \\
\text { is the PRMS-simulated monthly average PET, }_{P R M S}^{\text {avg }} & \begin{array}{l}
\text { in inches. }
\end{array}
\end{aligned}
$$

The initial values of $S F A C_{P E T}$ ranged from 0.973 to 1.082 .

\section{Integrated Hydrologic Model Calibration Results}

This section of the report describes the results of the ONIHM calibration and includes summaries of the fit between measured or observed calibration targets and their simulated equivalent model outputs. This section includes a summary of the final best parameter values from the model calibration. The section concludes with a discussion of composite parameter sensitivities.

\section{Comparison of Calibration Targets to Simulated Equivalents}

During the calibration process, PEST compares the observation targets to their time and space equivalent simulated values. PEST then calculates the difference between the observation targets and simulated equivalent values, which for the remainder of the report will be referred to as the "residual." A positive residual indicates an underestimation of simulated values by the ONIHM, and a negative residual indicates an overestimation of simulated values by the ONIHM; therefore, a residual is a direct indication of a model's ability to simulate past trends and conditions.

\section{Groundwater Levels}

Mean groundwater-level residuals for the four water-level observation groups measdevwl, estdevwl, lswlck, and syndevwl (table 4) were $31.62,12.90,-0.05$, and $7.27 \mathrm{ft}$, respectively, indicating that the ONIHM generally underestimated the groundwater levels. The ONIHM demonstrated a good fit between measdevwl and estdevwl water levels and their simulated equivalents, with coefficient of determination $\left(R^{2}\right)$ values of 0.795 (fig. 13) and 0.647 , respectively. The syndevwl group, with an $R^{2}$ value of 0.355 , did not fit well with simulated groundwater levels, but this was expected because those observations were measured after the end of the model simulation period and were consequently weighted lower in the calibration. As a result, PEST was not substantially affected by the syndevwl group during calibration and did not adjust the calibration parameters to produce a better match. The syndevwl group residual of $7.27 \mathrm{ft}$ was the lowest among the calibration target groups related to groundwater levels, excluding the lswlck group; however, this is likely because there were much fewer calibration targets than other groups

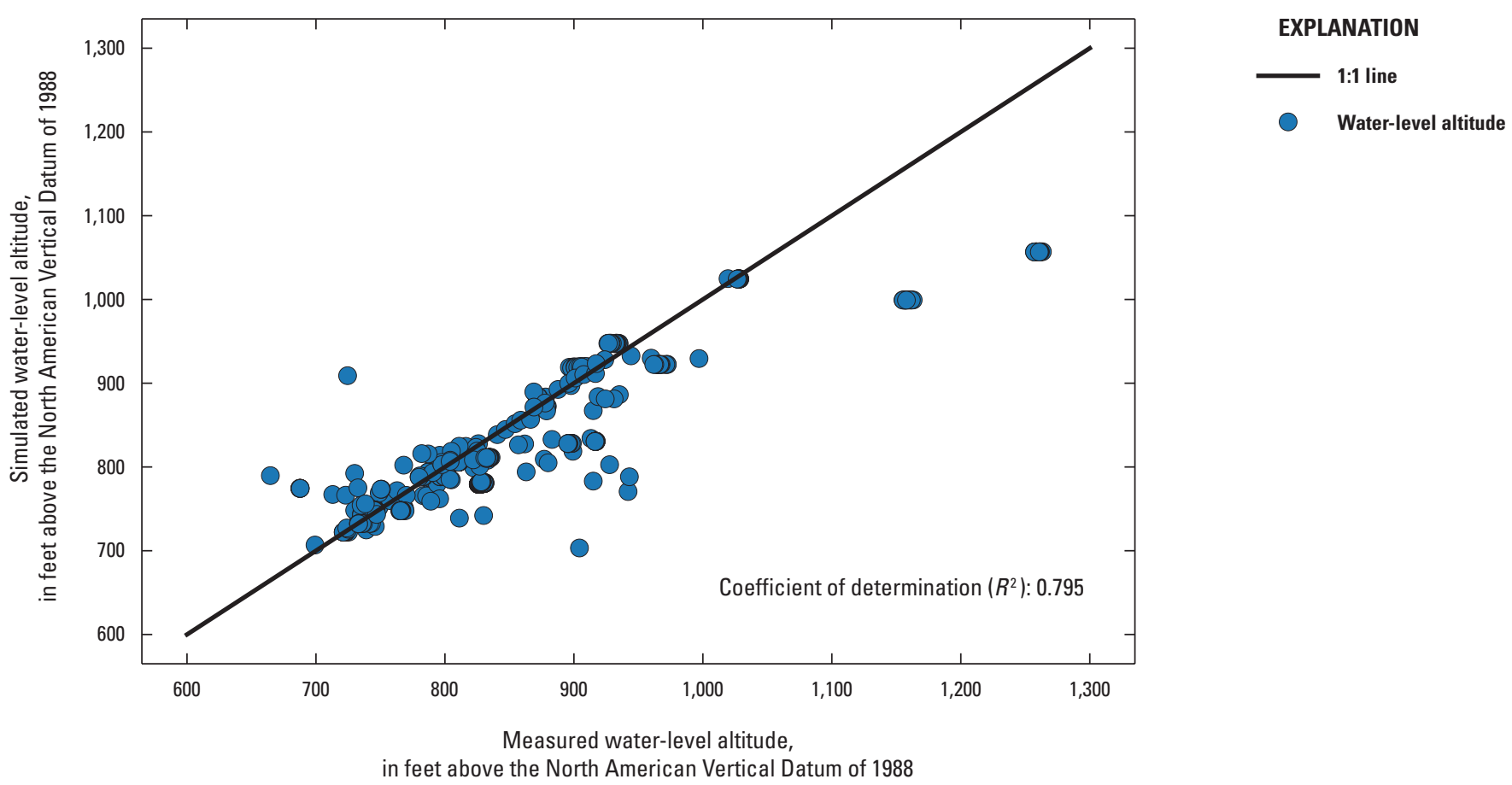

Figure 13. Measured versus simulated water-level altitudes and their coefficient of determination $\left(R^{2}\right)$ values for the measdevwl groundwater-level observation group used in the Osage Nation Integrated Hydrologic Model, from January 1950 to September 2014. 
(table 4). The ONIHM simulated groundwater levels below the land surface for 98 percent of the active model cells. The mean residual of $-0.05 \mathrm{ft}$ for the 2 percent of cells where groundwater levels were simulated above land surface is within the error from resampling the DEM to the 1,312.34-ft ONIHM grid size, and these cells were focused along streams where the stream stage, which is above land surface, represents the water table. Additionally, the $l s w l c k$ group observations were utilized to ensure that the model did not simulate a substantial number of water levels above land surface.

The ONIHM underestimated groundwater levels for the simulation period (1950-2014) across most regions and model layers of the active model domain (table 5). Layer 1 groundwater levels demonstrated a "spin up" period that was only 1 to 3 years because of the higher $K h$ values that allowed for the groundwater system to come into a quasi-equilibrium faster than in the lower hydraulic conductivity layers of the ONIHM. This "spin up" period was longer in layers 2 through 8 because of the one or two orders of magnitude decrease in $K h$ compared to layer 1 . This "spin up" period was used in layers 2 through 8 to adjust to the initial groundwater levels and come into a quasi-equilibrium with the hydrologic system during the first 15 years (1950-64) of the calibration for the 1950-2014 model; however, even with the "spin up" period, most areas had somewhat stable water levels that did not fluctuate more than $10 \mathrm{ft}$ for the duration of the 1950-2014 period. Groundwater levels in the southern region of the model around the upper parts of Keystone Lake demonstrated "spin up" periods that lasted through the 1950-2014 period and never reached a quasi-equilibrium like other regions of the groundwater system; this is evidence that the groundwater levels in those areas reacted to the specified initial groundwater levels and not to the stresses imposed during the 1950-2014 period. The groundwater levels in this region decreased throughout the 1950-2014 period, which indicates that the initial groundwater levels were too high.

Spatially, the ONIHM underestimated groundwater levels throughout the active model domain. The mean groundwaterlevel residual was positive for layers 1, 2, 3, 4, 6, and 8 and negative for layers 5 and 7 (table 5). The mean groundwaterlevel residual was largest for layer 6 at $44.0 \mathrm{ft}$ and smallest for layer 5 at $-12.4 \mathrm{ft}$ (table 5). The largest mean absolute residual was for layer 2 at $62.9 \mathrm{ft}$ and the smallest mean absolute residual was for layer 8 at $15.3 \mathrm{ft}$. Groundwater-level hydrographs from layer 1 demonstrated the most apparent response to changes in precipitation, whereas groundwater-level hydrographs from all other layers demonstrated little to no response to changes in precipitation.

Early in the calibration process, there was some bias in the mean groundwater-level residuals that caused PEST to preferentially reduce the residuals of the calibration targets of the estdevwl observation group that stemmed from the number of observations per group and the error-based weighting scheme of those observations. Observation group estdevwl contained many more observations than measdevwl and syndevwl (table 4), so PEST originally preferentially reduced the estdevwl residuals. It is preferred that PEST change parameters during calibration to reduce residuals between measured data and their simulated equivalent values before it tries to reduce residuals between estimated data and their simulated equivalent values. To allow PEST to preferentially reduce residuals of measured data in the measdevwl observation group and

Table 5. The 1950-2014 period Osage Nation Integrated Hydrologic Model calibration results, by layer, including groundwater-level altitude statistics, horizontal hydraulic conductivity, anisotropy, and streambed vertical hydraulic conductivity.

[Ksb; hydraulic conductivity of the streambed; $K h$, horizontal hydraulic conductivity; $K v$, vertical hydraulic conductivity; ft NAVD 88 , feet above the North American Vertical Datum of 1988 ; $\mathrm{ft} / \mathrm{d}$, foot per day; $\mathrm{ft}$, foot; $<$, less than]

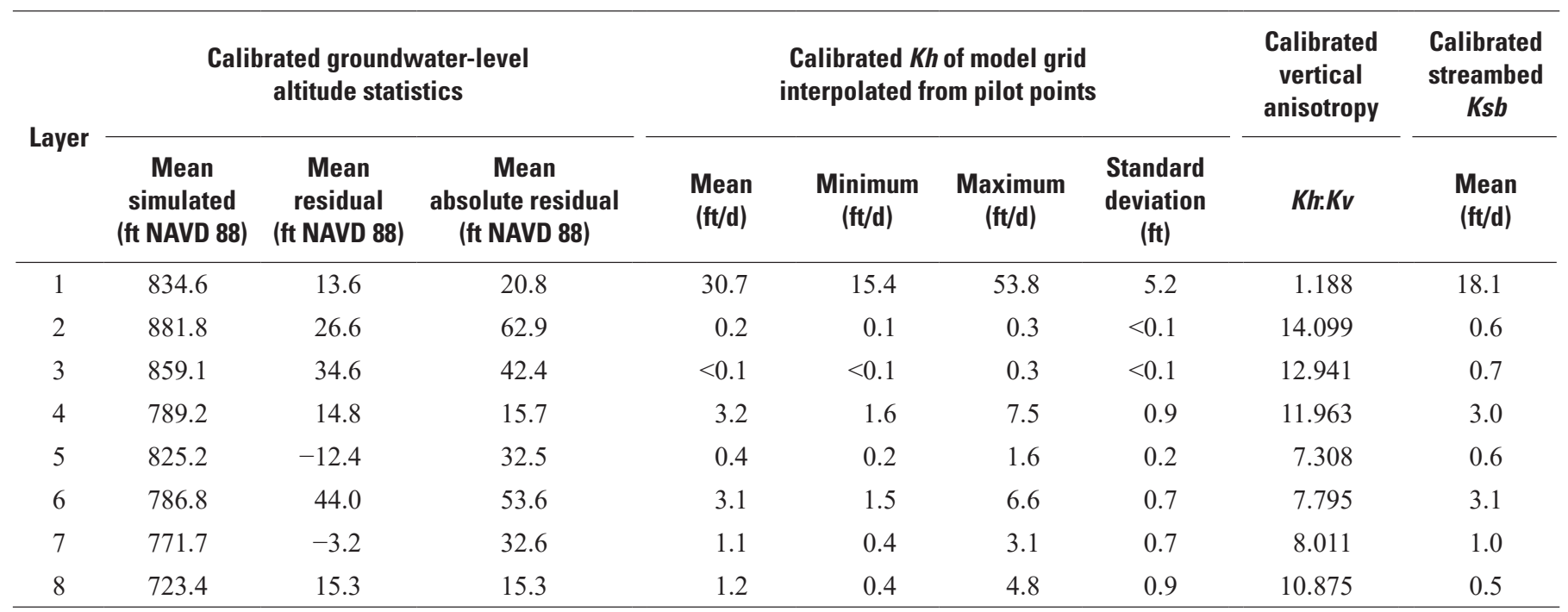


improve the match between measdevwl observation targets and their simulated equivalent values, the weights of the observation targets from estdevwl were manually lowered until the $\Phi$ for estdevwl was less than the $\Phi$ for the measdevwl. The final calibration demonstrated that measdevwl contribution to $\Phi$ was second highest of the observation group $\Phi$ 's (table 6). Therefore, measdevwl was one of the primary observation groups that guided PEST during automated calibration.

A water-table contour map for September 30, 2014, was created using groundwater-level altitudes in the uppermost active layer from the final stress period of the calibrated 1950-2014 period ONIHM (fig. 14, available for download as a layered PDF at https://doi.org/10.3133/sir20205141). Simulated water-table contours were like water-table contour maps created in Andrews and Smith (2014) and indicated topographically driven groundwater-flow directions. The topographic high in the north-central region is a watershed and groundwater divide where west of the topographic high, groundwater flows to the south toward Salt Creek and the Arkansas River, and to the east, groundwater flows east toward the major tributaries like Sand Creek, Bird Creek, and Hominy Creek. Along the southern region of the study area, south of the Arkansas River, groundwater flows north toward the Arkansas River.

Table 6. Observation count by Parameter Estimation software (PEST) observation group, calibrated mean streamflow residuals and groundwater-level residuals by observation group, and contribution to the initial and final objective function for each observation group for the 1950-2014 period Osage Nation Integrated Hydrologic Model. Refer to table 4 for a description of the observation groups.

[objective function, $\Phi$ ]

\begin{tabular}{lrcrr}
\hline $\begin{array}{c}\text { Observation } \\
\text { group }\end{array}$ & Count & $\begin{array}{c}\text { Mean } \\
\text { calibrated } \\
\text { residual, from } \\
\text { measured/ } \\
\text { estimated }\end{array}$ & $\begin{array}{c}\text { Starting } \\
\text { contribution } \\
\text { to } \mathbf{\Phi}\end{array}$ & $\begin{array}{c}\text { Final } \\
\text { calibration } \\
\text { contribution } \\
\text { to } \mathbf{\Phi}\end{array}$ \\
\hline \multicolumn{5}{c}{ Streamflow } \\
\hline devflux & 5,307 & $82^{\mathrm{a}}$ & $2,021,770$ & $1,079,570$ \\
devfluxprms & 8,679 & $93^{\mathrm{a}}$ & 513,264 & 246,317 \\
flowchng & 4,341 & $118^{\mathrm{a}}$ & $3,107,770$ & $1,630,800$ \\
flowchngprms & 7,314 & $-63^{\mathrm{a}}$ & $1,162,080$ & 529,643 \\
devfluxenr & 142 & $86^{\mathrm{a}}$ & 6,271 & 1,573 \\
\hline \multicolumn{5}{c}{ Groundwater level } \\
\hline measdevwl & 713 & $31.6^{\mathrm{b}}$ & 965,193 & $1,126,360$ \\
estdevwl & 95,636 & $12.9^{\mathrm{b}}$ & 443,690 & 458,868 \\
lswlck & 47,017 & $-0.05^{\mathrm{b}}$ & 59 & 35 \\
syndevwl & 71 & $7.3^{\mathrm{b}}$ & 206,867 & 210,735 \\
\hline
\end{tabular}

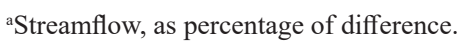

${ }^{\mathrm{b}}$ Groundwater level, in feet.

\section{Streamflows}

The ONIHM simulated total streamflow for all streams in the 1950-2014 period using PEST to change parameters and reduce residuals between the observation targets and their simulated equivalent values. The ONIHM underestimated total streamflow for most streams after calibration was complete (tables 6 and 7). A graphical comparison indicated that the ONIHM produced a good fit between measured streamflows and simulated equivalents for all streamflow observation groups (fig. 15A-D). The ONIHM best fit the flow change observation targets (flowchng) and streamflow observation targets from PRMS-estimated streamflows (devfluxprms), with $R^{2}$ values of 0.961 and 0.954 , respectively.

Four out of five streamflow observation groups had positive mean calibrated residuals (table 6). Observation groups devflux and devfluxprms had the largest mean calibrated streamflow residuals, 433.2 and $57.6 \mathrm{ft}^{3} / \mathrm{s}$ which were 82 and 93 percent of their mean streamflow, respectively, and observation groups flowchng and flowchngprms had the smallest mean calibrated streamflow residuals, 0.05 and $0.2 \mathrm{ft}^{3} / \mathrm{s}$ which were 118 and -63 percent of their mean streamflow, respectively (table 6). The small mean calibrated streamflow residuals for the flow change groups (flowchng and flowchngprms) indicated that the ONIHM adequately simulated the monthly changes in streamflow at each streamgage. The positive mean calibrated streamflow residuals for the measured and estimated streamflow groups (devflux and devfluxprms) indicated that the ONIHM underestimated streamflows. Streamflows were underestimated by a greater amount for the measured streamflows (devflux) than for the PRMS-estimated streamflows (devfluxprms; table 6). PRMS-estimated streamflows were used to specify stream inflows into the model area or below reservoirs at 19 locations within the SFR package, and these trends and magnitudes in the inflows likely propagated downstream and biased the ONIHM simulated streamflows at these locations and contributed to the lower residuals for the devfluxprms observation group.

The calibrated 1950-2014 period ONIHM produced the best fit between measured streamflow observation targets and their simulated equivalent values at the large streams in the study area (mean annual streamflow greater than $500 \mathrm{ft}^{3} / \mathrm{s}$ ), particularly the three streamgages along the Arkansas River. Mean streamflow residuals as a percentage of mean measured streamflow at the Arkansas River near Ponca City, Okla. (USGS station 07148140); Arkansas River at Ralston, Okla. (USGS station 07152500); and Arkansas River downstream, above Keystone Lake (PRMS-estimated) streamgages were lowest of all streamgage locations with values of -3.5 , 6.5 , and 8.0 percent, respectively, which indicated that the model produced a good fit between measured and simulated streamflows along the Arkansas River. Mean residuals for each streamgage were $-118,373$, and $493 \mathrm{ft}^{3} / \mathrm{s}$, respectively (table 7), which was between 3 and 9 percent of mean measured streamflow. The calibrated 1950-2014 period ONIHM produced a mean residual of $57 \mathrm{ft}^{3} / \mathrm{s}$ at the Caney River at 


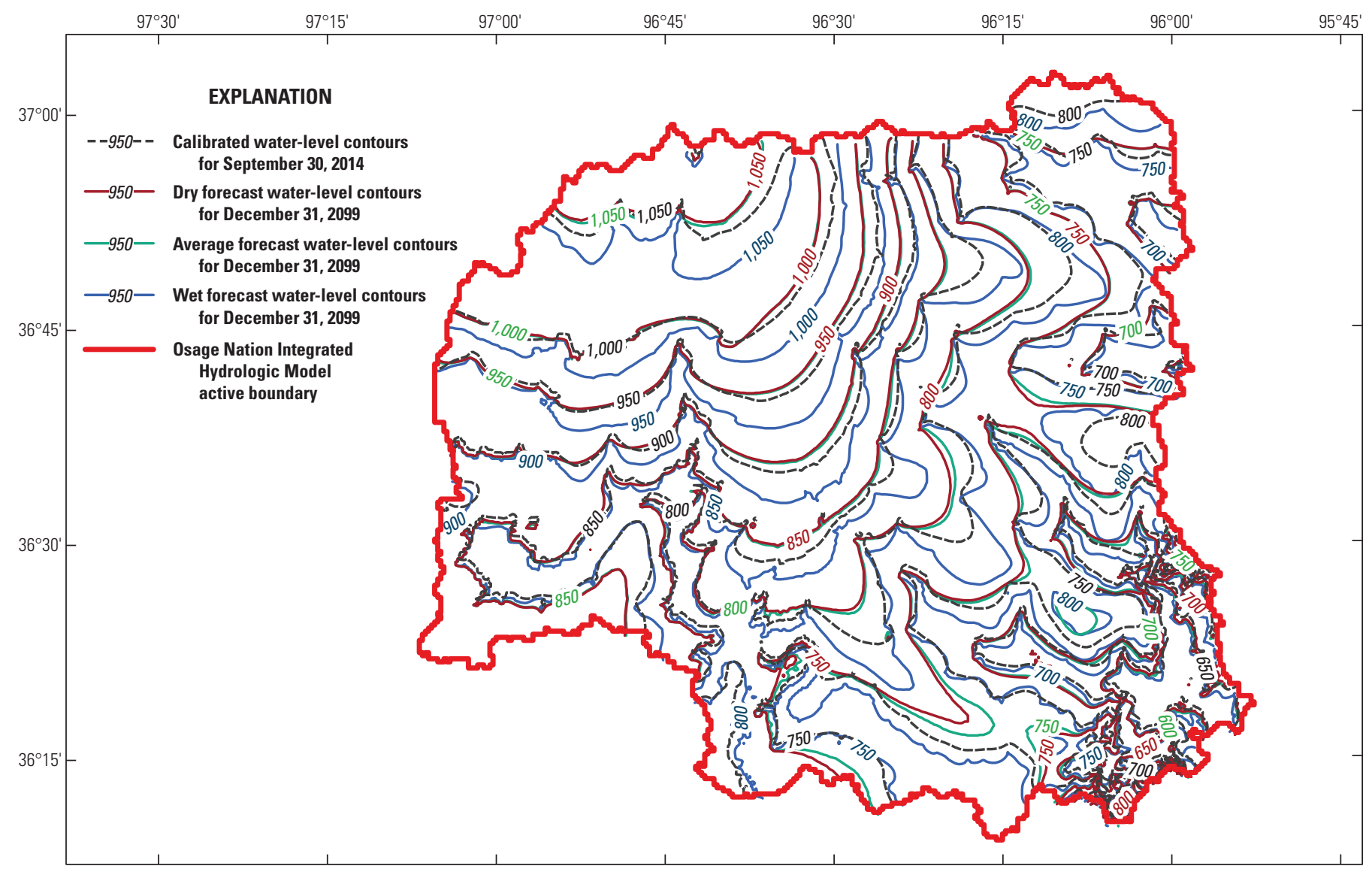

Base modified from U.S. Geological Survey digital data, 2015

Osage Nation Integrated Hydrologic Model active boundary modified Albers Equal-Area Conic projection

Standard parallels $29^{\circ} 50^{\prime} \mathrm{N}$. and $45^{\circ} 50^{\prime} \mathrm{N}$.

Central meridian $96^{\circ} 00^{\prime} \mathrm{W}$.

North American Vertical Datum of 1983

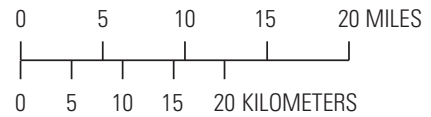

Figure 14. Simulated groundwater-level altitude contours for the final stress period of the calibrated Osage Nation Integrated Hydrologic Model (September 30, 2014), dry forecast (December 31, 2099), average forecast (December 31, 2099), and wet forecast (December 31, 2099). This figure is a layered PDF.

Hulah, Okla. (USGS station 07173000), which was 10 percent of the mean measured streamflow. The calibrated 1950-2014 period ONIHM produced a good fit between observation targets and simulated equivalent values at the Arkansas River near Ponca City, Okla. (USGS station 07148140), and Caney River at Hulah, Okla. (USGS station 07173000), because these streamgages are within a few miles of the inflow points of these streams to the active model domain. The specified inflows to SFR at these inflow points have trends that propagate downstream to other streamgage locations because the magnitude of streamflow is much larger than any tributary flows. As a result, measured streamflow observation targets for Arkansas River near Ponca City, Okla. (USGS station 07148140), and Caney River at Hulah, Okla. (USGS station 07173000), demonstrate trends from the specified SFR inflow points of the streams that were not a part of the calibration process. Residuals of calibration targets for streams that originated within the ONIHM active domain, and were not affected by a reservoir (Hominy Creek near Hominy, Okla. [USGS station 07176950], Hominy Creek near Skiatook, Okla. [USGS station 07177000], Sand Creek at Okesa, Okla. [USGS station 07174600], and Candy Creek near Wolco, Okla. [USGS station 07176800]), did not show the same trend because they did not require PRMS-generated inflows to the SFR package.

The ONIHM underestimated streamflows for the smaller streams (less than $500 \mathrm{ft}^{3} / \mathrm{s}$ ) in the study area, except for the two streamgages on Hominy Creek near Skiatook, Okla. (USGS stations 07177000 and 07177410 ; table 7). Overall, residuals deviated from mean measured streamflow for the small streams by 40 percent for the 1950-2014 period. The underestimation of streamflow in smaller streams was 
Table 7. Calibrated mean streamflow residuals and calibrated mean streamflow residuals as a percentage of measured streamflow for each measured and estimated streamgage location for the 1950-2014 period Osage Nation Integrated Hydrologic Model.

[OK, Oklahoma; nr, near; PRMS, Precipitation Runoff Modeling System; abv, above]

\begin{tabular}{|c|c|c|c|c|c|}
\hline Station number & Station name & Count & $\begin{array}{l}\text { Mean measured } \\
\text { streamflow, } \\
\text { in cubic feet per } \\
\text { second }\end{array}$ & $\begin{array}{c}\text { Mean calibrated } \\
\text { streamflow residual, } \\
\text { in cubic feet per } \\
\text { second }\end{array}$ & $\begin{array}{l}\text { Mean streamflow residual, } \\
\text { as a percentage of mean } \\
\text { measured streamflow }\end{array}$ \\
\hline 07152500 & Arkansas River at Ralston, OK & 777 & 5,754 & 373 & 6.5 \\
\hline 07174600 & Sand Creek at Okesa, OK & 777 & 88 & 29 & 33.0 \\
\hline 07176465 & $\begin{array}{l}\text { Birch Creek }{ }^{2} \text { below Birch } \\
\text { Lake }^{2} \text { nr Barnsdall, OK }\end{array}$ & 326 & 35 & 17 & 48.6 \\
\hline 07176500 & Bird Creek at Avant, OK & 777 & 250 & 131 & 52.4 \\
\hline 07176800 & Candy Creek ${ }^{2}$ near Wolco, OK & 777 & 22 & 9 & 40.9 \\
\hline 07177410 & $\begin{array}{l}\text { Hominy Creek below Skiatook } \\
\text { Lake nr Skiatook, OK }\end{array}$ & 377 & 171 & -91 & -53.2 \\
\hline 07177500 & Bird Creek at Sperry, OK & 777 & 571 & 80 & 14.0 \\
\hline PRMS estimated & $\begin{array}{l}\text { Salt Creek upstream, } \\
\text { nr Shidler, OK }\end{array}$ & 777 & 48 & 19 & 39.6 \\
\hline PRMS estimated & $\begin{array}{l}\text { Salt Creek downstream, } \\
\text { nr Fairfax, OK }\end{array}$ & 777 & 133 & 56 & 42.1 \\
\hline PRMS estimated & $\begin{array}{l}\text { Arkansas River downstream, } \\
\text { abv Keystone Lake, OK }\end{array}$ & 777 & 6,149 & 493 & 8.0 \\
\hline
\end{tabular}

${ }^{1}$ Hulah, Okla., not shown in figure 1 and no longer exists.

${ }^{2}$ Not labeled in figure 1.

likely related to the model's underestimated groundwater levels, which reduced the connection between streams and the groundwater-flow system. The devfluxenr observation group discrete streamflow measurements were also taken in small streams, and with a mean calibrated residual of $0.9 \mathrm{ft}^{3} / \mathrm{s}$ (86 percent of the measured streamflow) (table 6), the simulated streamflow at these locations was biased low likely due to the model's underestimation of groundwater levels. Due to the uncertainty and low observation weight, the devfluxenr observations had a negligible effect of the calibration.

\section{Calibration Parameter Results}

This section of the report describes the final calibrated values of the 231 parameters in 5 parameter groups specified for the ONIHM. The following sections will provide a summary of the final calibrated parameter values and a comparison to the initial parameter values to illustrate how the calibration changed the parameter values to produce the best fit between the observation targets and their simulated equivalents. The summaries will be partitioned into groundwater-centric parameters (pilotpts and aqprops groups) contained in the core MODFLOW-NWT functionality of the ONIHM, stream properties (sfrprops group), and the landscape and climate parameters (farmprops group) contained in the FMP functionality of the ONIHM. A sensitivity analysis also summarizes which parameters had the largest effect on the calibration process.

\section{Horizontal Hydraulic Conductivity Interpolated from Pilot} Points

Calibrated $K h$ interpolated from the 156 pilot points in the pilotpts group resulted in minor deviations from the initial estimated values specified at the beginning of the calibration. The $K h$ grids produced from interpolation of the calibrated 


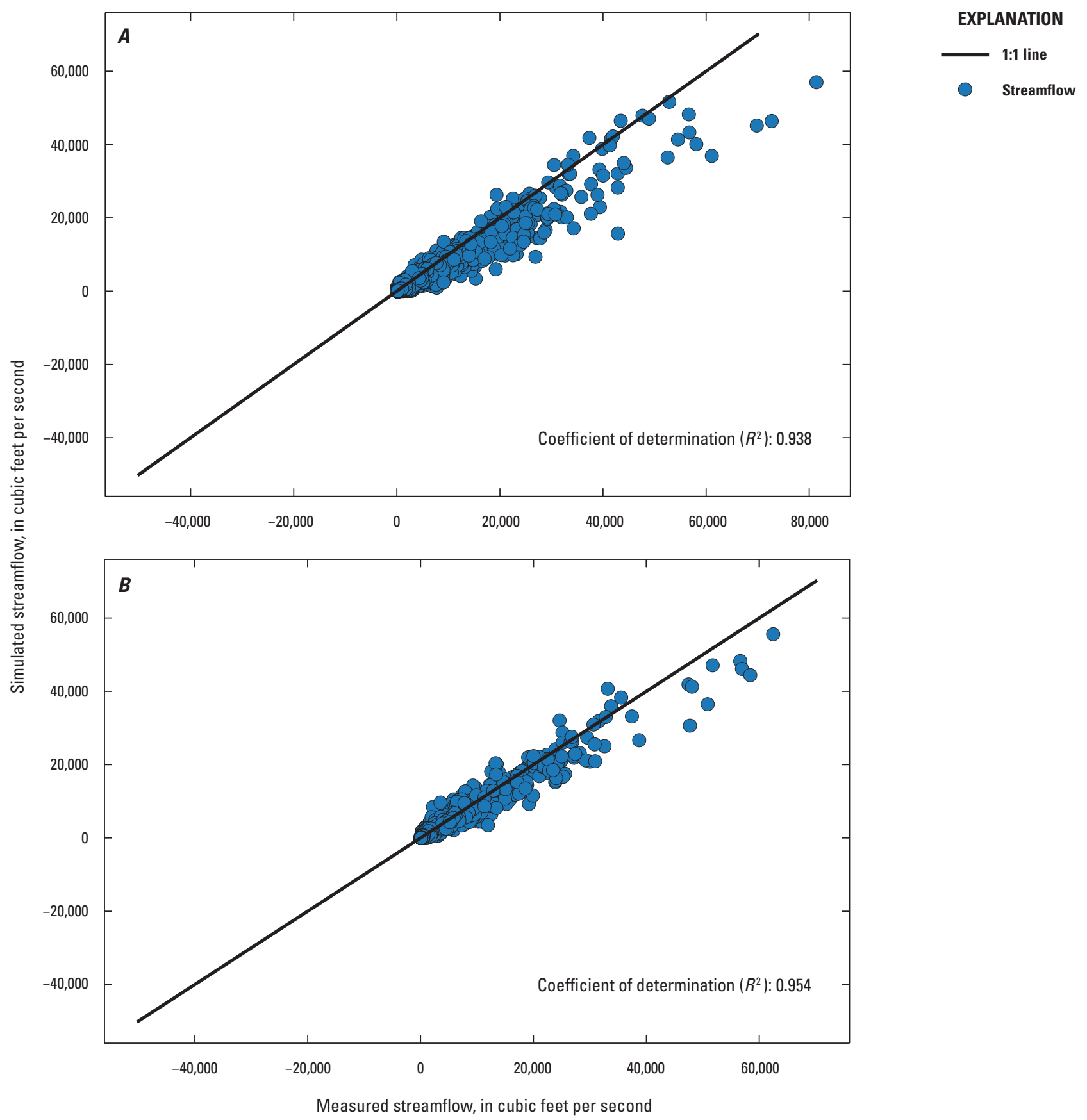

Figure 15. Linear regression plots of measured/estimated versus simulated streamflows and their coefficient of determination $\left(R^{2}\right)$ values for streamflow observation groups. $A$, devflux, $B$, devfluxprms; $C$, flowchng; and $D$, flowchngprms, for the Osage Nation Integrated Hydrologic Model, from January 1950 to September 2014. 


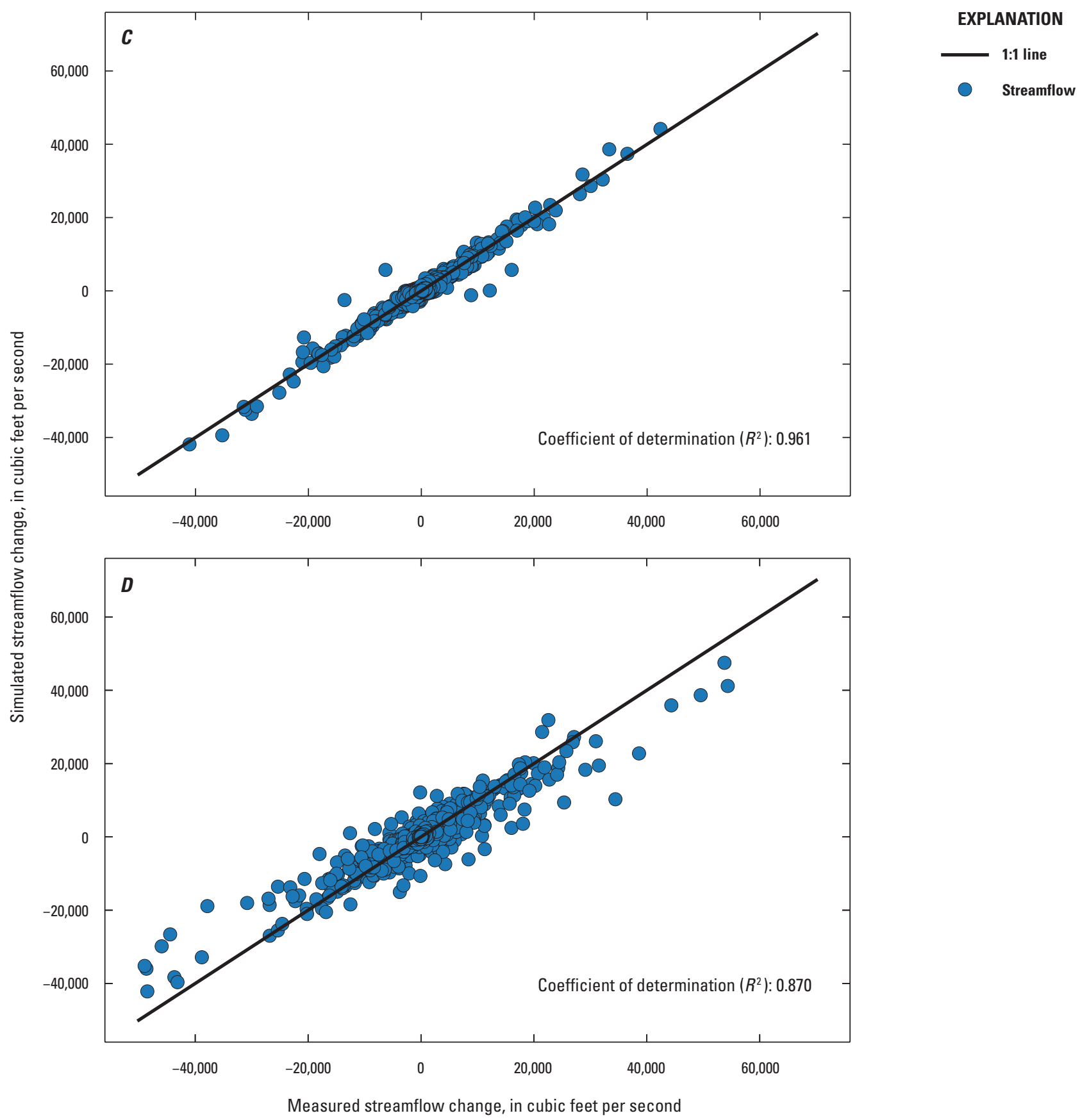

Figure 15. Linear regression plots of measured/estimated versus simulated streamflows and their coefficient of determination $\left(R^{2}\right)$ values for streamflow observation groups. $A$, devflux, $B$, devfluxprms; $C$, flowchng; and $D$, flowchngprms, for the Osage Nation Integrated Hydrologic Model, from January 1950 to September 2014.-Continued 
pilot points had mean values for layers 1 through 8 that ranged from $<0.1$ to $30.7 \mathrm{ft} / \mathrm{d}$ (table 5). The highest $K h$ values were in layer 1, and the lowest values were in layer 3 , which was consistent with the conceptual model and hydrostratigraphy of the area. Calibrated $K h$ values did not change enough from initial values to alter the hydrologic connection between layers developed in the conceptual model. Typically, in groundwater modelling, $K h$ is one of the main parameters that affects simulated groundwater levels. An increase in $K h$ facilitates groundwater flow between cells and lowers groundwater levels. Conversely, a decrease in $K h$ reduces groundwater flow between cells and increases groundwater levels. Often during calibration, if the model underestimates groundwater levels, PEST will attempt to improve the fit between the observation targets and simulated equivalent values by lowering $K h$ values in the offending layers. However, in ONIHM, the hydrostratigraphy and associated low initial $K h$ values for layers 2 through 8 did not promote much groundwater flow in the simulation. As a result, a decrease in $K h$ below the initial values was likely inconsequential, which made those parameters relatively insensitive because $K h$ did not make substantial changes to model outputs during the model calibration process.

The model grid $K h$ arrays generated by interpolation between the calibrated pilot points had almost identical layer by layer mean, minimum, and maximum values when compared to the pilot point values (table 5). This similarity demonstrated that the interpolation accurately reproduced the trends from the calibrated pilot points. The small standard deviation of $K h$ across each layer and visual analysis of the grids demonstrated that spatial variance in $K h$ was minimal to nonexistent.

\section{Vertical Anisotropy}

The vertical anisotropy, an aquifer property in the aqprops group, defined in the "PEST Calibration Parameters" section, changed slightly for all layers during calibration. Calibration increased the mean vertical anisotropy from 8.88 to 9.27. Calibration increased vertical anisotropy for layers 1,2 , 3,4 , and 8 and decreased it for layers 5, 6, and 7; final vertical anisotropy by layer are listed in table 5 . A decrease in vertical anisotropy facilitated the vertical movement of groundwater within the layer, and an increase in vertical anisotropy restricted the vertical movement of groundwater within the layer; however, the changes in vertical anisotropy from initial specified values were not large enough to change the hydrologic connection between layers.

\section{Streambed Vertical Hydraulic Conductivity}

Each of the eight $K s b$ parameters in the sfrprops group deviated from their initial values during calibration. The calibration decreased the mean $K s b$ from 5.35 to $3.48 \mathrm{ft} / \mathrm{d}$; final $K s b$ values by layer are listed in table 5. Decreases in $K s b$ reduce the groundwater interaction with the stream by slowing the groundwater flow to the stream or reducing the infiltration of stream water back to the aquifer. The largest changes were a 45-percent decrease in $K s b$ for layer $1(32.8$ to $18.1 \mathrm{ft} / \mathrm{d})$ and a 54-percent increase for layer $7(0.66$ to $1.0 \mathrm{ft} / \mathrm{d})$. The Arkansas River flowed primarily in layer 1 of the model and was the dominant stream feature for layer 1 for the active model area. The $K s b$ for all other layers did not deviate substantially from their initial values.

\section{Farm Process Calibrated Parameter Values}

Parameters for the landscape and climate functionality (farmprops and climprops groups) within the FMP Package of the ONIHM, which are defined in the "Farm Process Calibration Parameters" section of this report, were adjusted by PEST from their initial values to improve the fit between observation targets and their simulated equivalents. The adjusted parameters included root depths, FIESWP, FIESWI, and scale factors for potential evapotranspiration. The final calibrated values for each of these parameters are discussed in this section of the report.

\section{Root Depth}

Root depths specified for each of the 10 land-use types were adjusted during calibration. All 10 root depth parameters deviated from their initial values. Calibrated pasture root depth decreased from 6.56 to $3.93 \mathrm{ft}$; final root depth values by land-use identifier are listed in table 8 . The other nine root depth parameters did not vary more than 15 percent from their initial values which is within the acceptable range of values. Calibrated values varied from their initial values because those initial values were general root depths that were not specific for the study area.

\section{Fraction of Inefficient Losses to Surface Water from Precipitation}

The FIESWP parameters defined for each of the 10 land uses in the ONIHM adjusted the fraction of precipitation that goes to runoff, but only 5 parameters (FIESWP parameters for sorghum, soybeans, winter wheat, other crops, and deciduous forest) deviated from initial specified values. FIESWP parameters for idle/fallow, pasture, urban, and alfalfa remained at their initial values of 0.9 and open water remained at its initial value of 0.999. FIESWP parameters for sorghum, soybeans, winter wheat, other crops, and deciduous forest decreased from their initial value of 0.9 to 0.848 to improve the calibration results; final FIESWP values by land-use identifier are listed in table 8.

The FIESWP scale factor (FIESWPsfac) specified for high precipitation months changed during the 1950-2014 period from its initial value of 1.05 to 0.99 . This decrease indicated that during high precipitation months, defined as greater than the 75 th percentile of monthly precipitation, runoff as a fraction of precipitation was not preferentially higher than during lower precipitation months. This parameter was specified to promote runoff on the assumption that the MF-OWHM method of removing ET or plant consumption 
Table 8. Calibration results for Farm Process parameters, by land use, in the 1950-2014 period Osage Nation Integrated Hydrologic Model.

[ft, foot; FIESWP, fraction of inefficient losses to surface water from precipitation; FIESWI, fraction of inefficient losses to surface water from irrigation]

\begin{tabular}{clccc}
\hline Land-use identifier & Land-use name & Root depth (ft) & FIESWP (fraction) & FIESWI (fraction) \\
\hline 1 & Idle/fallow & 0.94 & 0.9 & 0.848 \\
2 & Pasture & 3.93 & 0.9 & 0.100 \\
3 & Urban & 1.14 & 0.9 & 0.350 \\
4 & Alfalfa & 2.89 & 0.9 & 0.080 \\
5 & Open water & 0.00 & 1 & 0.990 \\
6 & Sorghum & 1.82 & 0.848 & 0.138 \\
7 & Soybeans & 1.48 & 0.848 & 0.112 \\
8 & Winter wheat & 1.76 & 0.848 & 0.071 \\
9 & Other crops & 2.00 & 0.848 & 0.065 \\
10 & Deciduous forest & 5.22 & 0.848 & 0.001 \\
\hline
\end{tabular}

from precipitation before partitioning runoff and recharge could underestimate runoff to streams; however, PEST arrived at a best value of 0.99 , which indicates the $1950-2014$ period ONIHM did not require an increase in runoff during high precipitation months. An FIESWPsfac of 0.99 only reduced runoff by an annual average of 0.07 in., and this was not substantial enough to alter the results.

\section{Fraction of Inefficient Losses to Surface Water from Irrigation}

The FIESWI parameters defined for each of the 10 land uses in the ONIHM adjusted the fraction of applied irrigation water that goes to runoff (table 8). Mean FIESWI decreased from 0.23 to 0.22 during calibration; final FIESWI values by land-use identifier are listed in table 8 . For land uses that required irrigation water (alfalfa, sorghum, soybeans, winter wheat, and other crops), these parameters deviated from 12 to 38 percent from their initial values to improve the calibration. The calibration did not change this parameter for nonirrigated land uses (pasture, urban, open water, and deciduous forest). The minor changes in this parameter were expected because irrigation was not a major water use in the study area.

\section{Scale Factors for Potential Evapotranspiration}

The 12 PET scale factors specified and changed during calibration were the parameters that had the greatest effect on the total amount of water available in the ONIHM because they changed the amount of water available for consumptive use and, subsequently, other landscape processes. The calibration increased the mean PET scale factors from 1.018 to 1.925; final PET scale factors for January through December were $3.00,3.24,1.71,0.99,1.11,1.15,1.67,1.25,1.79,1.61$,
2.96, and 3.82, respectively (Traylor and Peterson, 2021). All 12 parameters differed from their initial values, and 8 of the 12 PET scale factors changed more than 50 percent from their initial values. Changes in PET values resulted in changes in simulated actual ET, runoff to streams, and recharge to the groundwater-flow system. Therefore, PET scale factors affected water budget fluxes across the landscape, soil zone, and water-table boundaries. This effect across multiple water budget components and flux boundaries in the ONIHM, including the largest component of actual ET, made the PET scale factors into sensitive parameters during calibration and is likely the reason PEST changed them by as much as 253 percent.

The largest changes from initial values were the parameters for January, February, November, and December, which increased between 179 and 253 percent. This increase caused a deviation in the monthly PET trend where calibrated PET for January, February, and March exceeded that of April (fig. 16). This is a deviation from the initial conceptual model of PET in the ONIHM (fig. 16). PEST likely changed these values to reduce the streamflow residuals for coincident months/stress periods. Analysis of the mean monthly streamflow residuals for several streamgages used during calibration indicated these streamgages demonstrated their highest monthly residuals for the nongrowing season months. This trend indicates there may be some bias in the observation targets or the ONIHMsimulated equivalent outputs. The observation targets may be biased through the conversion of measured daily streamflow to mean monthly streamflows that did not accurately capture the nongrowing season streamflow trends. Also, the calibrated 1950-2014 period ONIHM may be biased by underestimating streamflow more during the nongrowing season months. 


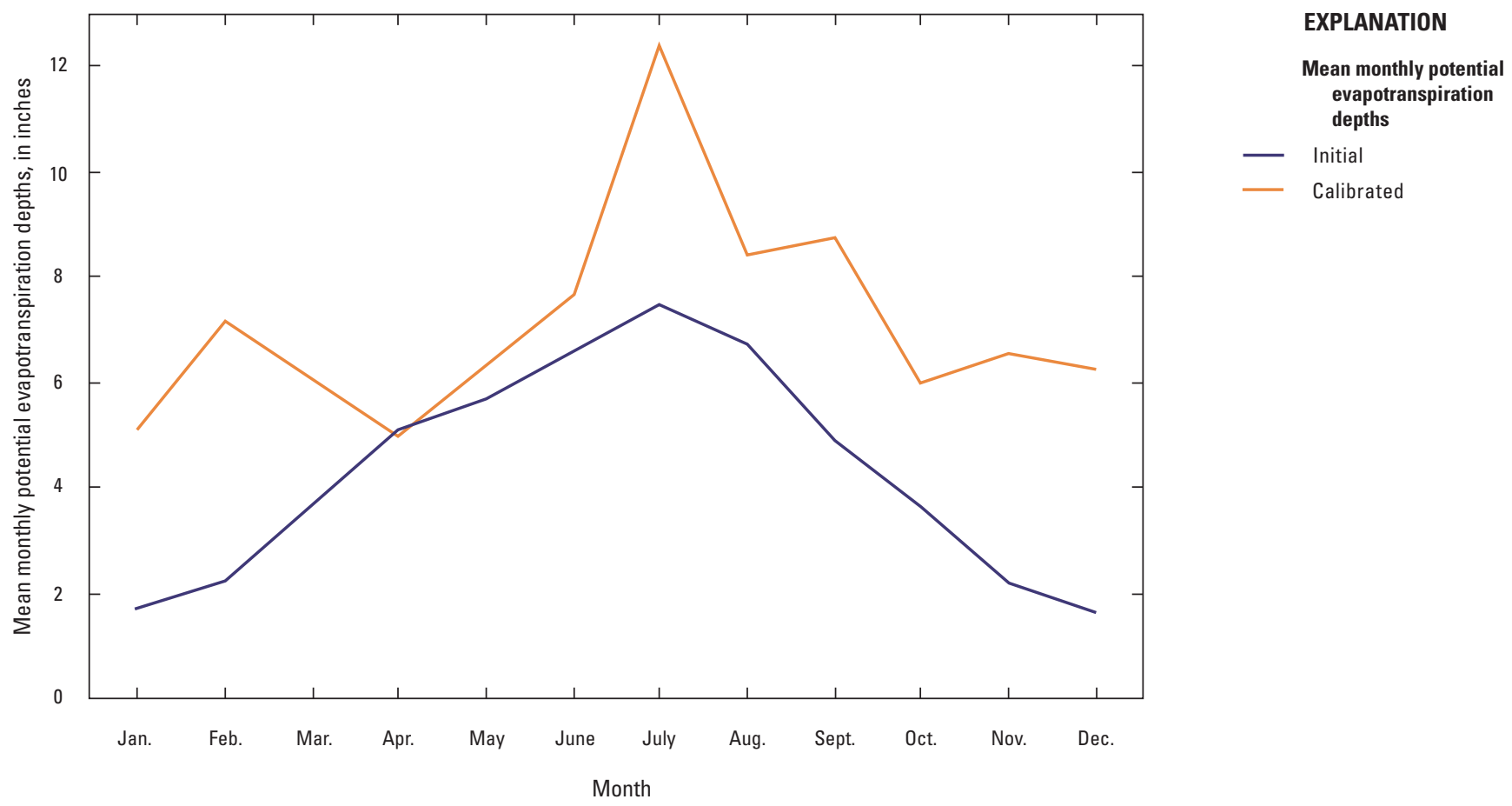

Figure 16. Comparison of initial and calibrated mean monthly potential evapotranspiration depths for the Osage Nation Integrated Hydrologic Model from January 1950 to September 2014.

\section{Sensitivity Analysis}

Sensitivity analysis quantifies the effect that a change in each parameter has on the residuals, where residuals are the observation targets minus their simulated equivalent (as previously noted in the "Calibration Targets" section of this report). The automated PEST software (Doherty, 2016) calculates sensitivities for all adjustable parameters to calibration targets. Parameter sensitivities were extracted from the Jacobian matrix and each residual was multiplied by the assigned weight (weighting of observations is described in the "Calibration Targets" section of this report). Sensitivities were then summed for each parameter group to produce composite parameter sensitivities by parameter group with respect to each observation group (fig. 17). Larger composite sensitivities indicate that those parameters had a larger effect on the model outputs and their residuals.

Parameter sensitivities varied for each observation group depending on several factors that included the number of observations per group, weighting of the observations, and the nature of the observations and the hydrologic processes and trends they represented in the model. Overall, the climprops parameter group had the highest mean composite sensitivity (fig. 17). Climprops were also the most sensitive parameter group to the devflux and devfluxprms observation groups: these observation groups were the measured streamflows at USGS streamgages and the PRMS-extracted streamflows (as described in the "Calibration Targets" section of this report) with sensitivities that were an order of magnitude greater than any other sensitivity. The climprops parameter group included the PET scale factors (described in the "Farm Process Calibration Parameters" section of this report) that experienced the largest change from their initial values during the calibration process (described in the "Integrated Hydrologic Model Calibration Results" section of this report), so it was not surprising that the climprops parameter group contained the most sensitive parameters. The estdevwl and measdevwl observation groups also were sensitive to the climprops parameter group. The pilotpts parameter group had the second highest mean composite sensitivity and was the most sensitive to the devflux and estdevwl observation groups. High pilot point sensitivities are in accord with typical hydrologic processes because PEST changes pilot-point values, which interpolate to $K h$ changes in the model. 


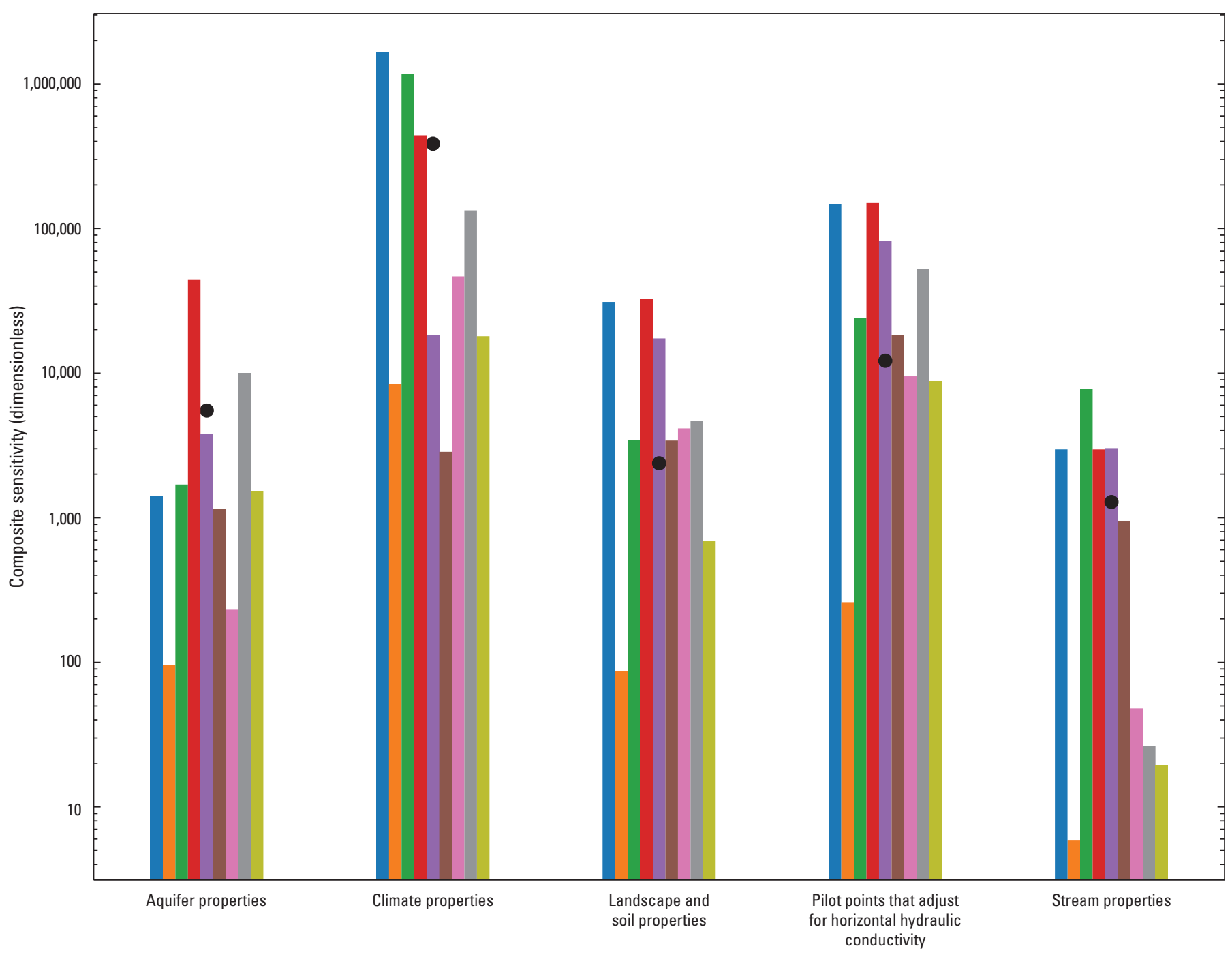

PEST calibration parameter group

EXPLANATION

- Mean composite sensitivity

Parameter estimation observation groups (see table $\mathbf{4}$ for group descriptions)

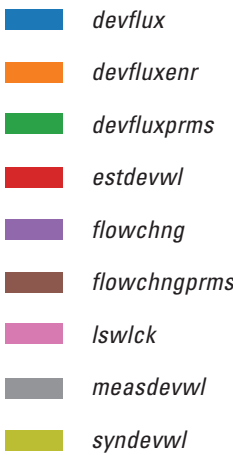

Figure 17. Sensitivity of computed observations to changes in Parameter Estimation (PEST) calibration parameters groups by PEST observation groups for the Osage Nation Integrated Hydrologic Model. 


\section{Water Availability Analysis and Simulated Water Budgets}

This section of the report presents the water budget results for all water budget components and boundary conditions simulated for all cells in the active model domain of the ONIHM during the 1950-2014 period and for three forecasts. Calibrated 1950-2014 period ONIHM water budget results are presented in the "Current Water Availability" section of this report, and the water budget results for the three forecasts are presented in the "Forecast Water Availability" section. Assessing water budgets provides an understanding of the magnitudes and distribution of fluxes across hydrologic boundaries in the ONIHM. Results are presented separately for the two major hydrologic systems simulated in the ONIHM (landscape water and groundwater-flow systems) to facilitate the comparison of results within each system.

All landscape water budget fluxes are presented with respect to the landscape, such that positive fluxes indicate inflows or additions of water to the landscape and negative fluxes indicate outflows from the landscape. Further, the groundwater budget fluxes are presented with respect to the groundwater-flow system, such that positive fluxes indicate inflows to the groundwater-flow system and negative fluxes indicate outflows from the groundwater-flow system. Fluxes for each water budget component of the hydrologic system presented as "net" fluxes represent the difference between inflows and outflows.

\section{Current Water Availability}

This section of the report presents the water budget results for the landscape and groundwater parts of the calibrated 1950-2014 period ONIHM. Summaries of water availability also are provided for the fresh/marginal groundwater and saline groundwater systems of the calibrated 1950-2014 period ONIHM. The ONIHM must obey the law of conservation of mass where the difference in total inflows and outflows is equal to zero. The efficacy of the ONIHM was verified by calculating the budget discrepancy, calculated as total inflows minus total outflows. Landscape water budget discrepancy between total inflows and total outflows was less than 0.01 percent of the total budget for all stress periods, which indicated that the landscape water budget obeyed the law of conservation of mass. The landscape water budget discrepancy does not include the groundwater ET components (Egw and Tgw) for shallow groundwater that evaporates (for example, wetlands) and transpiration of groundwater (for example, plants with roots that pull water from the water table) even though they were represented as outflows from the landscape. These were hybrid components that involve both the landscape and groundwater systems; however, the water from these components originated in the groundwater-flow system. Therefore, Egw and Tgw were not included as a part of inflows or outflows during the landscape water budget component calculations, but they were included in the groundwater budget. The groundwater-flow budget discrepancy between total inflows and total outflows was less than 1.0 percent of the total budget for all but one stress period. Stress period 119 had a groundwater-flow budget discrepancy of 1.04 percent, which was a minor deviation that did not affect model results and indicated that the groundwater-flow water budget obeyed the law of conservation of mass. Based on the calibrated 1950-2014 period ONIHM's underestimation of groundwater levels described in the "Groundwater Levels" section, the groundwater-flow budget results presented hereafter are conservative estimates.

\section{Landscape Water Budget}

The landscape water budget components include net inflows of precipitation and irrigation water and outflows of evaporation, transpiration, and runoff, with evaporation and transpiration partitioned by their source of either precipitation or irrigation water (table 9). Individual magnitudes of inflow and outflow components of the landscape water budget demonstrated substantial annual variation during the 1950-2014 period (fig. 18). The largest inflow component was precipitation $\left(\mathrm{P}_{\text {land }}\right)$ and the largest outflow component was transpiration of precipitation (Tp). Total inflows to the landscape are the sum of $\mathrm{P}_{\text {land }}$ and irrigation wells $\left(\operatorname{Irr}_{\text {wells }}\right)$, with a mean annual value of 7,823.0 ft3 $/ \mathrm{s}$ or $36.6 \mathrm{in} / \mathrm{yr}$. During the 1950-2014 period, precipitation accounted for 99.99 percent of the total inflows to the landscape, with a mean annual value of $7,820.2 \mathrm{ft}^{3} / \mathrm{s}$ or $36.6 \mathrm{in} / \mathrm{yr}$; the remainder was from groundwater applied to crops via $\operatorname{Irr}_{\text {wells }}$ with a mean annual value of $2.8 \mathrm{ft}^{3} / \mathrm{s}$ or less than $0.01 \mathrm{in} / \mathrm{yr}$ for the total active model area, where $\operatorname{Irr}_{\text {wells }}$ supplies groundwater to crops that did not receive adequate water from precipitation or root uptake and irrigation wells were available to supply the required water. Mean $\mathrm{Tp}$ accounted for 64 percent of the total mean outflows with a mean annual value of $5,032.2 \mathrm{ft}^{3} / \mathrm{s}$ or $23.5 \mathrm{in} / \mathrm{yr}$. Total mean ET from precipitation (sum of evaporation and transpiration of precipitation) accounted for 85 percent of total mean outflows compared to 76 percent for the same ONIHM area simulated by the PRMS model in Hevesi and others (2020). Runoff of precipitation to streams (RO) accounted for 13 percent of the total mean outflows with a mean annual value of $998.4 \mathrm{ft}^{3} / \mathrm{s}$ (table 10), or $4.7 \mathrm{in} / \mathrm{yr}$. Simulated RO for the ONIHM was less than the 7.3 in. simulated by the PRMS model in Hevesi and others (2020). Deep percolation of precipitation past the root zone (DP) was only 1.9 percent (mean annual value of $-148.9 \mathrm{ft}^{3} / \mathrm{s}$ or $0.7 \mathrm{in} / \mathrm{yr}$.) of total outflows, which indicated that recharge is not a substantial part of the water budget. This was less than the 4 to 10 percent from Wilkins (1997); however, the results of that study were from an adjacent region with more annual precipitation. Simulated mean DP for the ONIHM ( $0.7 \mathrm{in} / \mathrm{yr})$ was less than the $1.2 \mathrm{in} / \mathrm{yr}$ of analogues recharge simulated by the PRMS model in Hevesi and others (2020). The differences between ET, RO, and DP for the ONIHM and the PRMS model can be attributed to the 
Table 9. Abbreviations and definitions of the simulated landscape water budget and groundwater-flow budget terms for the 0sage Nation Integrated Hydrologic Model.

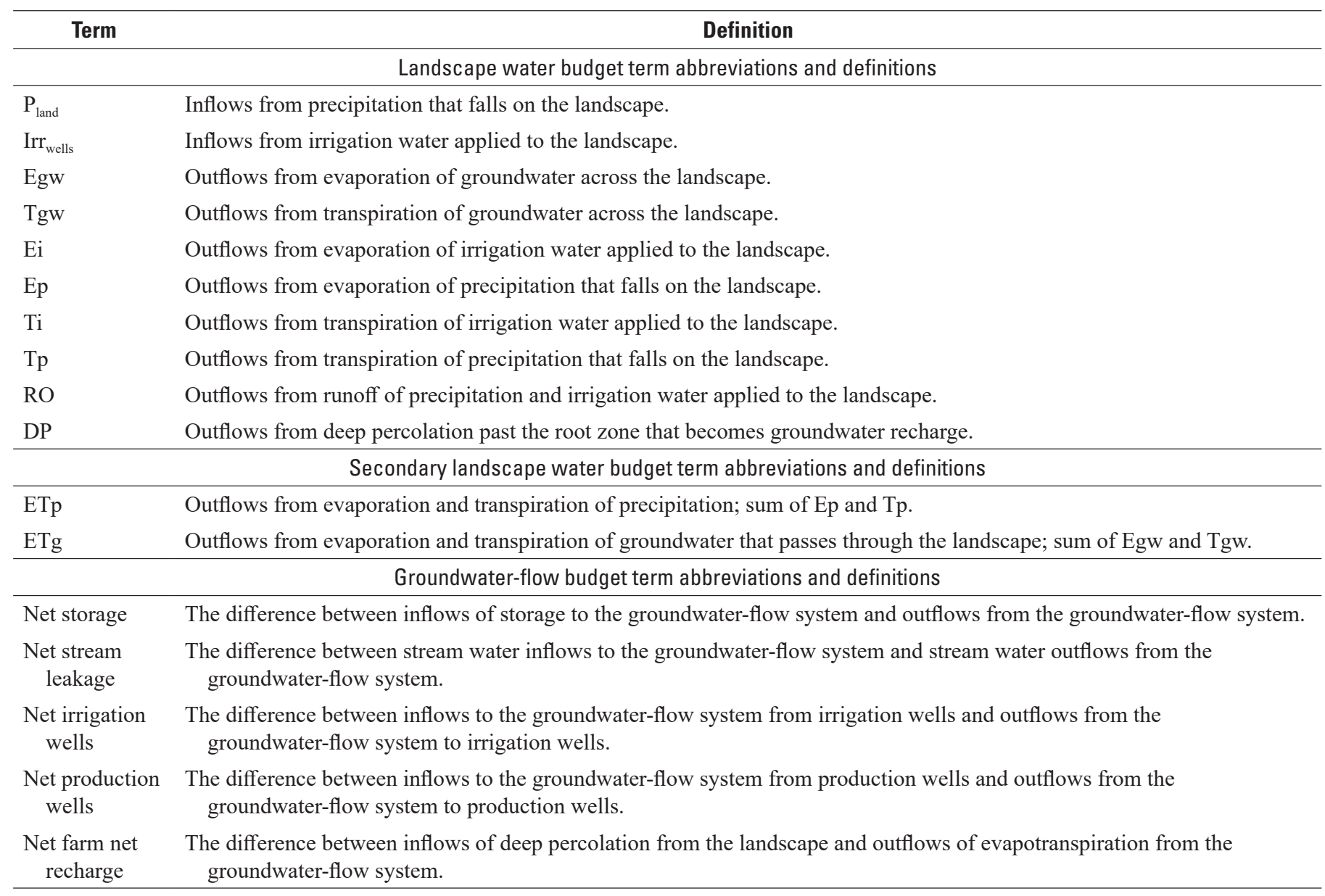

PRMS software's more detailed mechanisms for calculating and routing water across the landscape. Other minor (less than 1 percent of landscape outflows) outflows from the landscape water budget in the OHIHM were evaporation and transpiration from applied irrigation water (Ei and Ti; table 10). ET from precipitation (ETp) demonstrated a strong correlation ( $R^{2}$ of 0.865$)$ to $\mathrm{P}_{\text {land, }}$, which indicated that ET, the major component of the landscape water budget, was driven primarily by precipitation (fig. 19).

The magnitudes of the fluxes for individual landscape water budget components varied from month to month for the 1950-2014 period (fig. 20). $\mathrm{P}_{\text {land }}$ was the largest inflow component for every month. Tp was the largest outflow component for 8 of the 12 months (April through November) when averaged across all stress periods. Ep was the largest outflow component for the other 4 months (December through March). RO was greatest for March through June when water availability for runoff, calculated as $\mathrm{P}_{\text {land }}$ minus ETp, also was the greatest (fig. 20). Like the annual landscape water budgets, monthly ETp demonstrated a strong correlation to precipitation, with an
$R^{2}$ value of 0.951 , which indicates that monthly precipitation trends affect the landscape hydrologic system at least at the finest temporal resolution of the ONIHM, which is monthly (fig. 21).

\section{Groundwater-Flow Budget}

Individual magnitudes of net components of the groundwater-flow budget demonstrated substantial annual variation during the 1950-2014 period (fig. 22). Annual variations in net groundwater storage and net farm net recharge correlated strongly with precipitation $\left(\mathrm{P}_{\text {land }}\right)\left(R^{2}\right.$ of 0.740 and 0.742 , respectively), which indicates that annual climate trends affected the groundwater-flow system each year (fig. $23 \mathrm{~A}$ and $B)$. Net stream leakage, net production wells, and irrigation well components demonstrated almost no correlation to precipitation ( $R^{2}$ less than 0.05$)$. The small number of production wells and irrigation wells in the study area did not deplete the groundwater storage, and therefore, their effects were minimal with respect to the total groundwater-flow budget. 


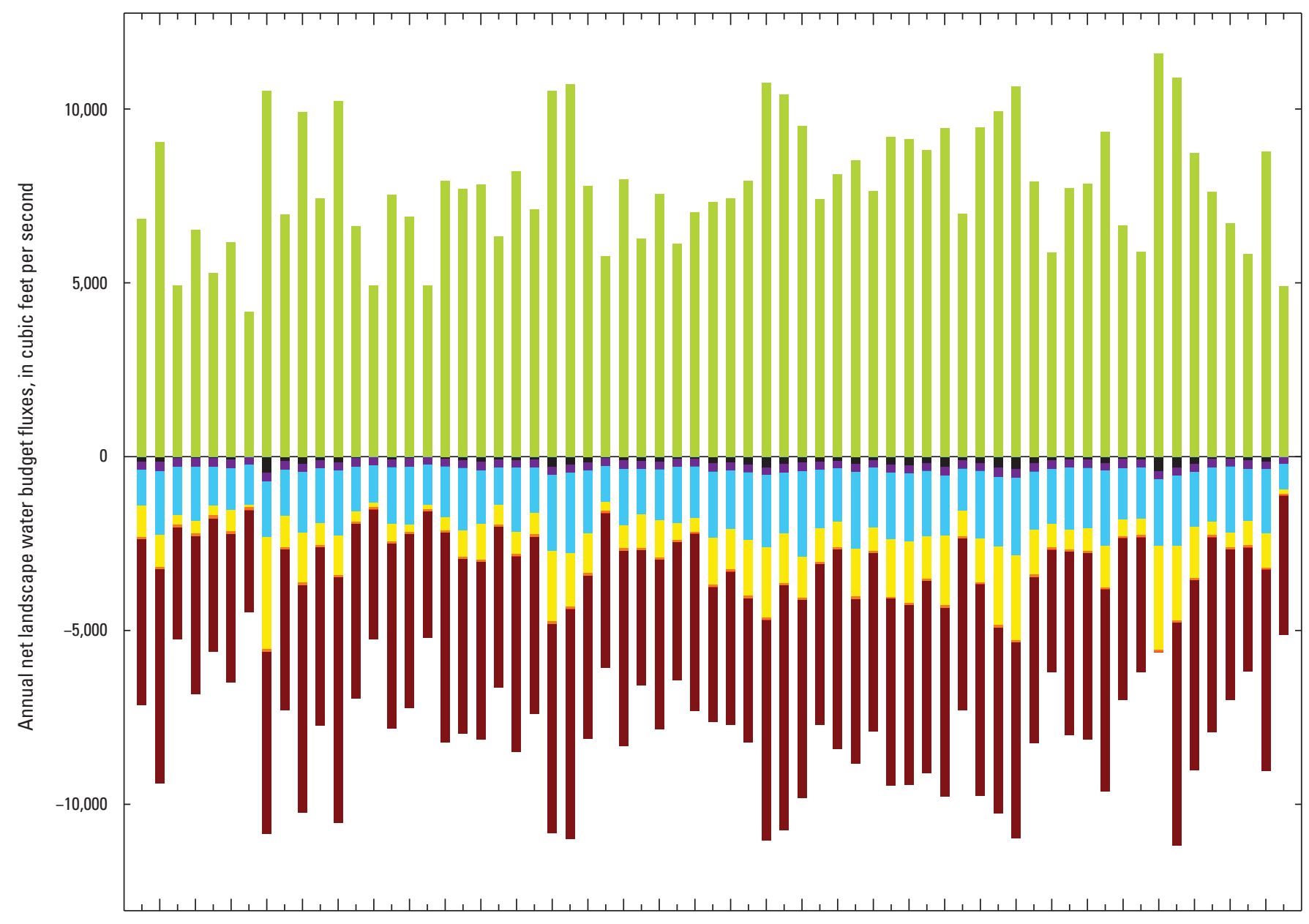

م

Year

EXPLANATION
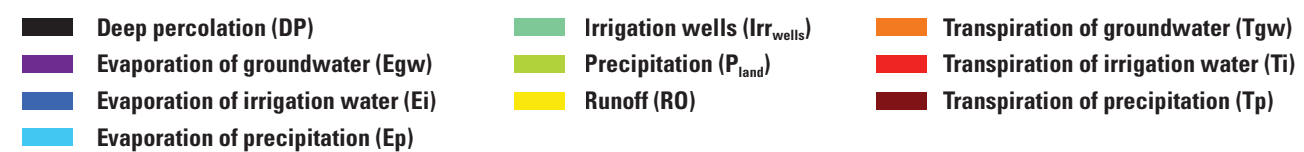

Figure 18. Annual fluxes of the simulated landscape water budget components for the Osage Nation Integrated Hydrologic Model from January 1950 to September 2014. 
Table 10. Simulated mean annual January 1950 to September 2014 net fluxes and mean annual January 1950 to September 2014 percentages of precipitation for the landscape water budget components for each supergroup and total active model area for the Osage Nation Integrated Hydrologic Model.

[--, no data (for ETp in the upper part of the table, there are no data entries because it is a secondary output that is the sum of Ep and Tp); NA, not applicable; negative fluxes indicate the removal of water from the landscape; positive fluxes indicate an addition of water to the landscape]

\begin{tabular}{|c|c|c|c|c|c|c|c|c|c|c|c|}
\hline Supergroup name & 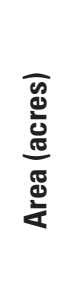 & 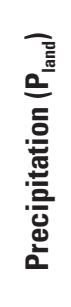 & 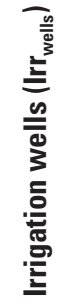 & 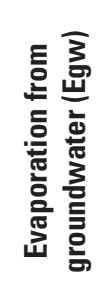 & 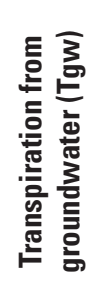 & 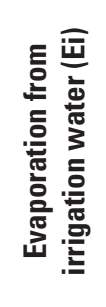 & 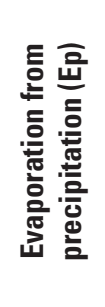 & 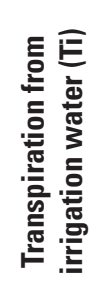 & 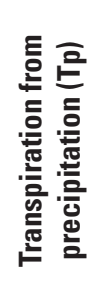 & 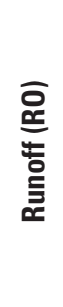 & 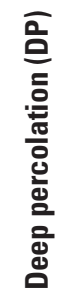 \\
\hline
\end{tabular}

\begin{tabular}{|c|c|c|c|c|c|c|c|c|c|c|c|c|c|}
\hline \multicolumn{14}{|c|}{ Mean annual net landscape fluxes for calibration model, in cubic feet per second } \\
\hline 1 & Bird Creek & 212,827 & $1,373.2$ & 0.0 & -17.2 & -9.4 & 0.0 & -260.8 & 0.0 & -907 & -178.9 & -26.5 & -- \\
\hline 2 & Salt Creek & 178,548 & 770.9 & 0.0 & -5.6 & -4.7 & 0.0 & -140.0 & 0.0 & -541.4 & -79.2 & -10.4 & -- \\
\hline 3 & Sand Creek & 154,115 & 660.7 & 0.0 & -5.7 & -3.9 & 0.0 & -123.7 & 0.0 & -436.1 & -87.2 & -13.6 & -- \\
\hline 4 & $\begin{array}{l}\text { Arkansas River } \\
\text { above Kaw Lake }\end{array}$ & 140,751 & 567.3 & 0.2 & -29.8 & -10.3 & 0.0 & -135.9 & -0.1 & -355.2 & -67.4 & -8.8 & -- \\
\hline 5 & $\begin{array}{l}\text { Arkansas River } \\
\text { below Kaw Lake }\end{array}$ & 481,401 & $2,167.2$ & 2.6 & -150.7 & -23.8 & -0.2 & -510.3 & -2.1 & $-1,323.3$ & -289.4 & -44.6 & -- \\
\hline 6 & Deciduous forest & 514,177 & $2,190.9$ & 0.0 & -82.1 & -29.2 & 0.0 & -460.7 & 0.0 & $-1,325.1$ & -346.3 & -58.7 & -- \\
\hline 7 & Pasture & $1,140,322$ & $4,785.8$ & 1.1 & -29.1 & -22.4 & -0.1 & -879.1 & -0.9 & $-3,320.4$ & -515.9 & -70.6 & -- \\
\hline 8 & Central Osage & 133,793 & 710.3 & 0.0 & -2.9 & -3.4 & 0.0 & -129.5 & 0.0 & -492.1 & -77.7 & -11.1 & -- \\
\hline 9 & $\begin{array}{l}\text { Hominy Creek } \\
\text { above Skiatook Lake }\end{array}$ & 242,835 & $1,015.0$ & 0.0 & -14.1 & -7.3 & 0.0 & -211.5 & 0.0 & -658.4 & -125.7 & -19.3 & -- \\
\hline 10 & Hominy Lake supply & 3,716 & 21.4 & 0.0 & 0.0 & 0.0 & 0.0 & -4.8 & 0.0 & -13.9 & -2.4 & -0.3 & -- \\
\hline 11 & Burbank Oil Field & 46,574 & 186.8 & 0.0 & -0.1 & -0.4 & 0.0 & -34.1 & 0.0 & -133 & -17.4 & -2.3 & -- \\
\hline 12 & Naval Reserves & 22,773 & 95.9 & 0.0 & 0.0 & -0.2 & 0.0 & -17.1 & 0.0 & -68.8 & -8.8 & -1.1 & -- \\
\hline & Total model area & $1,858,905$ & $7,820.2$ & 2.8 & -237.0 & -70.2 & -0.2 & $-1,641.1$ & -2.2 & $-5,032.2$ & -998.4 & -148.9 & -- \\
\hline \multicolumn{14}{|c|}{ Percentage of precipitation for calibration model } \\
\hline 1 & Bird Creek & 212,827 & 100.0 & 0.0 & NA & NA & 0.0 & -19.0 & 0.0 & -66.1 & -13.0 & -1.9 & -85.1 \\
\hline 2 & Salt Creek & 178,548 & 100.0 & 0.0 & NA & NA & 0.0 & -18.2 & 0.0 & -70.2 & -10.3 & -1.3 & -88.4 \\
\hline 3 & Sand Creek & 154,115 & 100.0 & 0.0 & NA & NA & 0.0 & -18.7 & 0.0 & -66.0 & -13.2 & -2.1 & -84.8 \\
\hline 4 & $\begin{array}{l}\text { Arkansas River } \\
\text { above Kaw Lake }\end{array}$ & 140,751 & 100.0 & 0.0 & NA & NA & 0.0 & -24.0 & 0.0 & -62.6 & -11.9 & -1.6 & -86.7 \\
\hline 5 & $\begin{array}{l}\text { Arkansas River } \\
\text { below Kaw Lake }\end{array}$ & 481,401 & 100.0 & 0.0 & NA & NA & 0.0 & -23.5 & -0.1 & -61.1 & -13.4 & -2.1 & -84.7 \\
\hline 6 & Deciduous forest & 514,177 & 100.0 & 0.0 & NA & NA & 0.0 & -21.0 & 0.0 & -60.5 & -15.8 & -2.7 & -81.7 \\
\hline 7 & Pasture & $1,140,322$ & 100.0 & 0.0 & NA & NA & 0.0 & -18.4 & 0.0 & -69.4 & -10.8 & -1.5 & -87.8 \\
\hline 8 & Central Osage & 133,793 & 100.0 & 0.0 & NA & NA & 0.0 & -18.2 & 0.0 & -69.3 & -10.9 & -1.6 & -87.6 \\
\hline 9 & $\begin{array}{l}\text { Hominy Creek } \\
\text { above Skiatook Lake }\end{array}$ & 242,835 & 100.0 & 0.0 & NA & NA & 0.0 & -20.8 & 0.0 & -64.9 & -12.4 & -1.9 & -85.8 \\
\hline 10 & Hominy Lake supply & 3,716 & 100.0 & 0.0 & NA & NA & 0.0 & -22.4 & 0.0 & -65.0 & -11.2 & -1.4 & -87.3 \\
\hline 11 & Burbank Oil Field & 46,574 & 100.0 & 0.0 & NA & NA & 0.0 & -18.3 & 0.0 & -71.2 & -9.3 & -1.2 & -89.5 \\
\hline \multirow[t]{2}{*}{12} & Naval Reserves & 22,773 & 100.0 & 0.0 & NA & NA & 0.0 & -17.8 & 0.0 & -71.7 & -9.2 & -1.1 & -89.6 \\
\hline & Total model area & $1,858,905$ & 100.0 & 0.0 & NA & NA & 0.0 & -21.0 & 0.0 & -64.3 & -12.8 & -1.9 & -85.4 \\
\hline
\end{tabular}




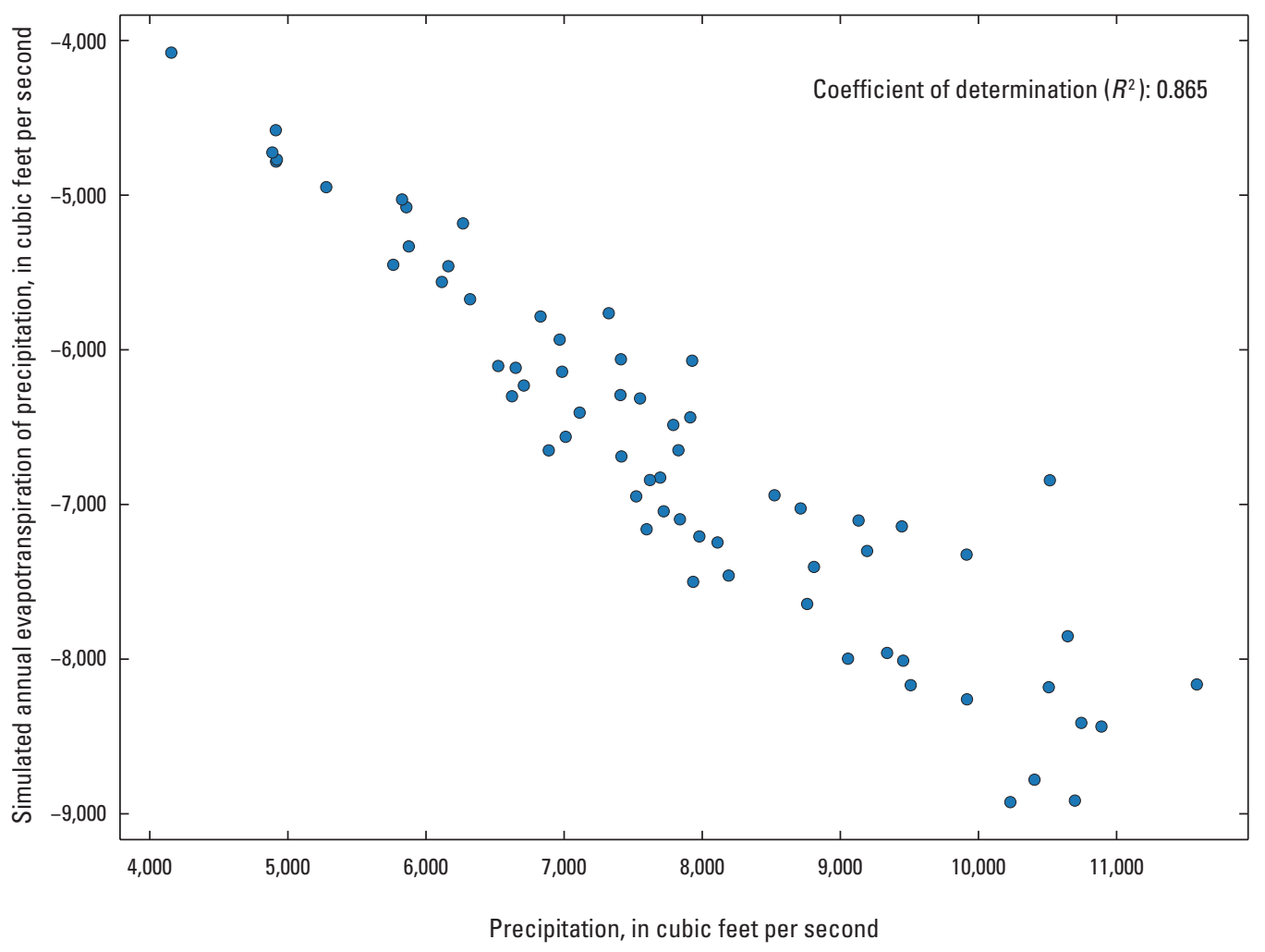

Figure 19. Linear regression of simulated annual evapotranspiration from precipitation and precipitation for the 0sage Nation Integrated Hydrologic Model from January 1950 to September 2014.

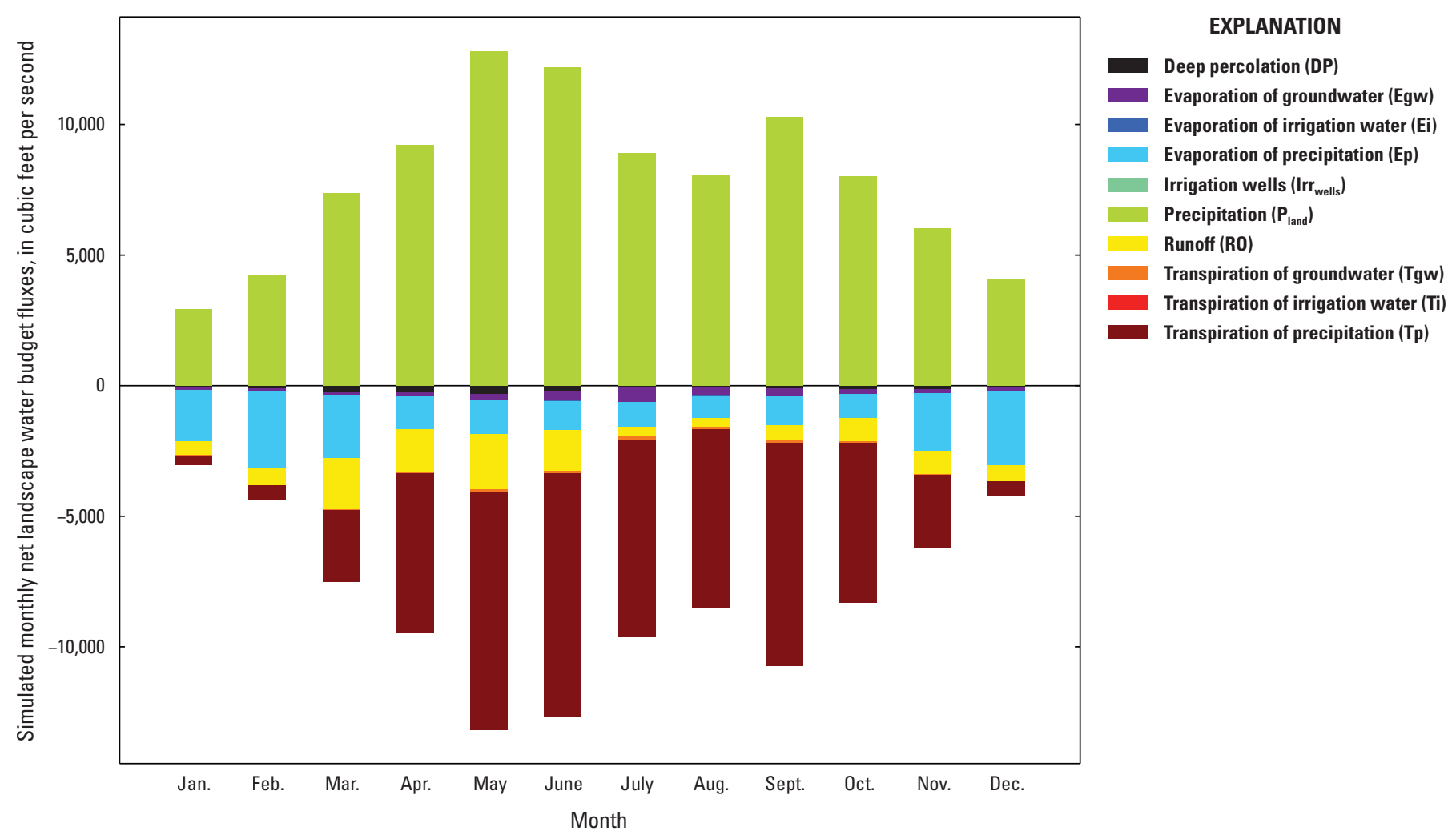

Figure 20. Monthly fluxes of the simulated landscape water budget components, from January 1950 to September 2014, of the 0sage Nation Integrated Hydrologic Model. 


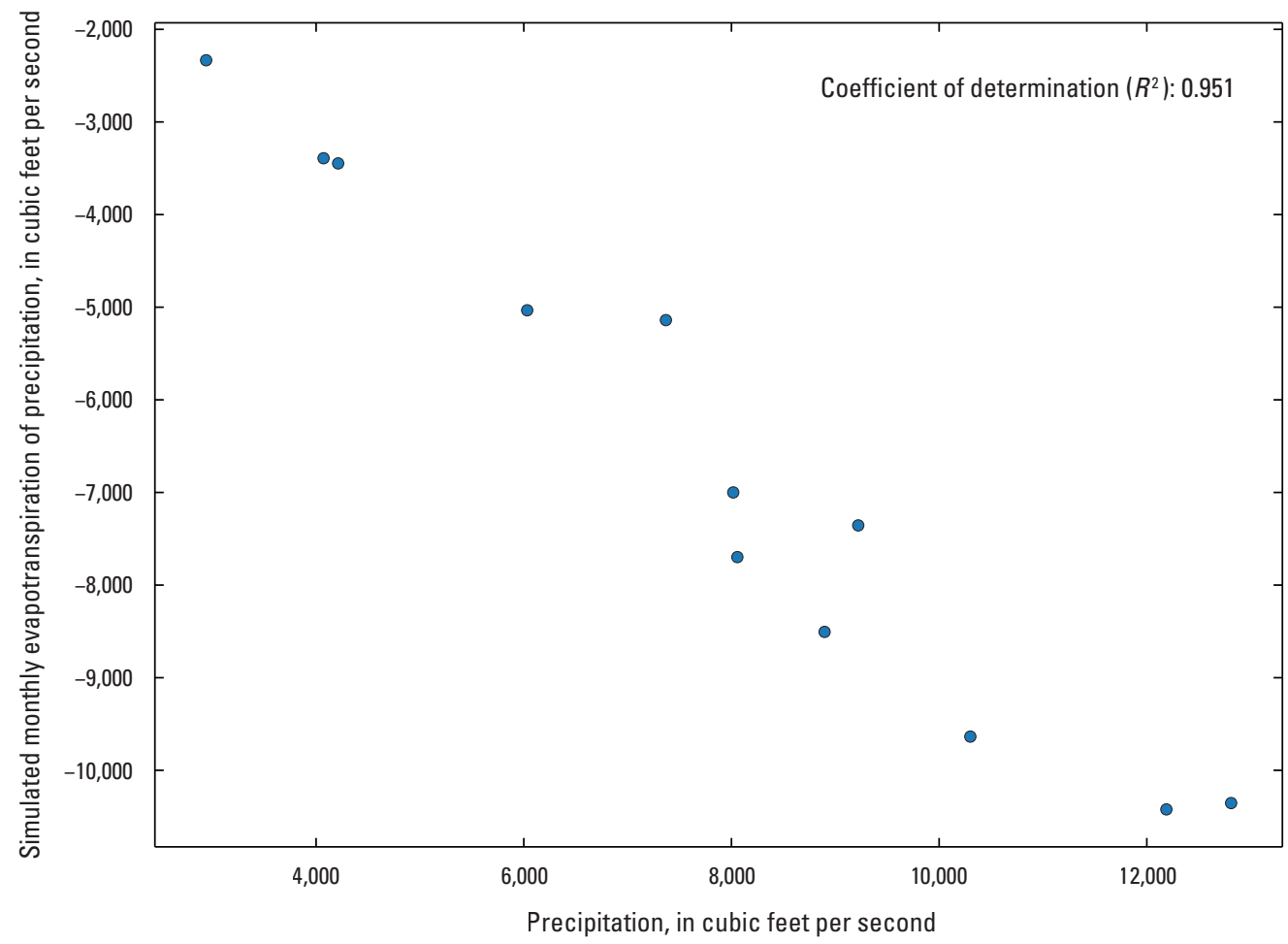

Figure 21. Linear regression of simulated monthly evapotranspiration from precipitation and precipitation for the Osage Nation Integrated Hydrologic Model from January 1950 to September 2014.
Net stream leakage was the largest inflow to the groundwater-flow system for all 65 simulated years (fig. 22). Mean annual net stream leakage for all years constituted 91 percent of the inflows to the groundwater-flow system which was a deviation from the conceptual model that is potentially a result of the underestimation of simulated water-levels in layer 1 (table 5), with a mean annual value of $152.5 \mathrm{ft}^{3} / \mathrm{s}$, and the remaining inflows were from net storage, with a mean annual value of $14.7 \mathrm{ft}^{3} / \mathrm{s}$ (table 11). The largest outflow component of the groundwater-flow system for 53 of the 65 simulation years was net farm net recharge [difference between deep percolation (or groundwater recharge) and groundwater ET], which constituted an average of 93 percent of mean total net outflows, with a mean annual value of $-153.4 \mathrm{ft}^{3} / \mathrm{s}$. A negative value of net farm net recharge indicated that groundwater consumed by ET was greater than deep percolation past the root zone (that is, recharge to the water table). The remaining 7 percent of outflows from the groundwater-flow system were from net production wells (in table 11 and fig. 22) and irrigation wells (in table 11 and fig. 22).

Individual magnitudes of fluxes in the groundwater-flow system varied from month to month (fig. 24). Mean monthly stream leakage was the largest inflow component to the groundwater-flow system for 10 of the 12 months, and the largest during the growing season months of April to October. For the other 2 months (January and March), net stream leakage was less than inflows of net groundwater storage and net farm net recharge (fig. 24). The largest mean monthly net outflows from the groundwater-flow system were farm net recharge, except for March and April when farm net recharge was an inflow as recharge to the groundwater-flow system. Based on the mean monthly net groundwater storage, the groundwater-flow system accumulated groundwater storage in February, March, April, May, June, and November when precipitation was highest, and ET of groundwater was not at maximum levels. Net groundwater storage (where negative values are replenishment to groundwater storage from the groundwater-flow system and indicate a rise in groundwater levels) demonstrated a strong negative correlation to net farm net recharge (difference between deep percolation/recharge to the water table and groundwater ET; $R^{2}$ of 0.83 ), which indicated that recharge to the water table was affected by the hybrid process ETgw and that recharge largely occurred where the water table was near the land surface, such as in stream valleys. Net groundwater storage moderately correlated with net stream leakage ( $R^{2}$ of 0.47$)$; thus, the primary process that affected groundwater levels was net farm net recharge.

Annually, stream leakage was predominantly a net inflow to the groundwater-flow system, which indicated that the overall stream network in the ONIHM was a "losing" system. Net stream leakage demonstrated less annual variation than other groundwater-flow budget components, indicating that it was the most stable groundwater-flow component during the 1950 2014 period. Mean monthly stream leakage was a net outflow for all months; however, the magnitudes varied for each month. Monthly, the overall stream system in the ONIHM was slightly "losing" during the nongrowing season months (January, February, November, and December) with a mean 


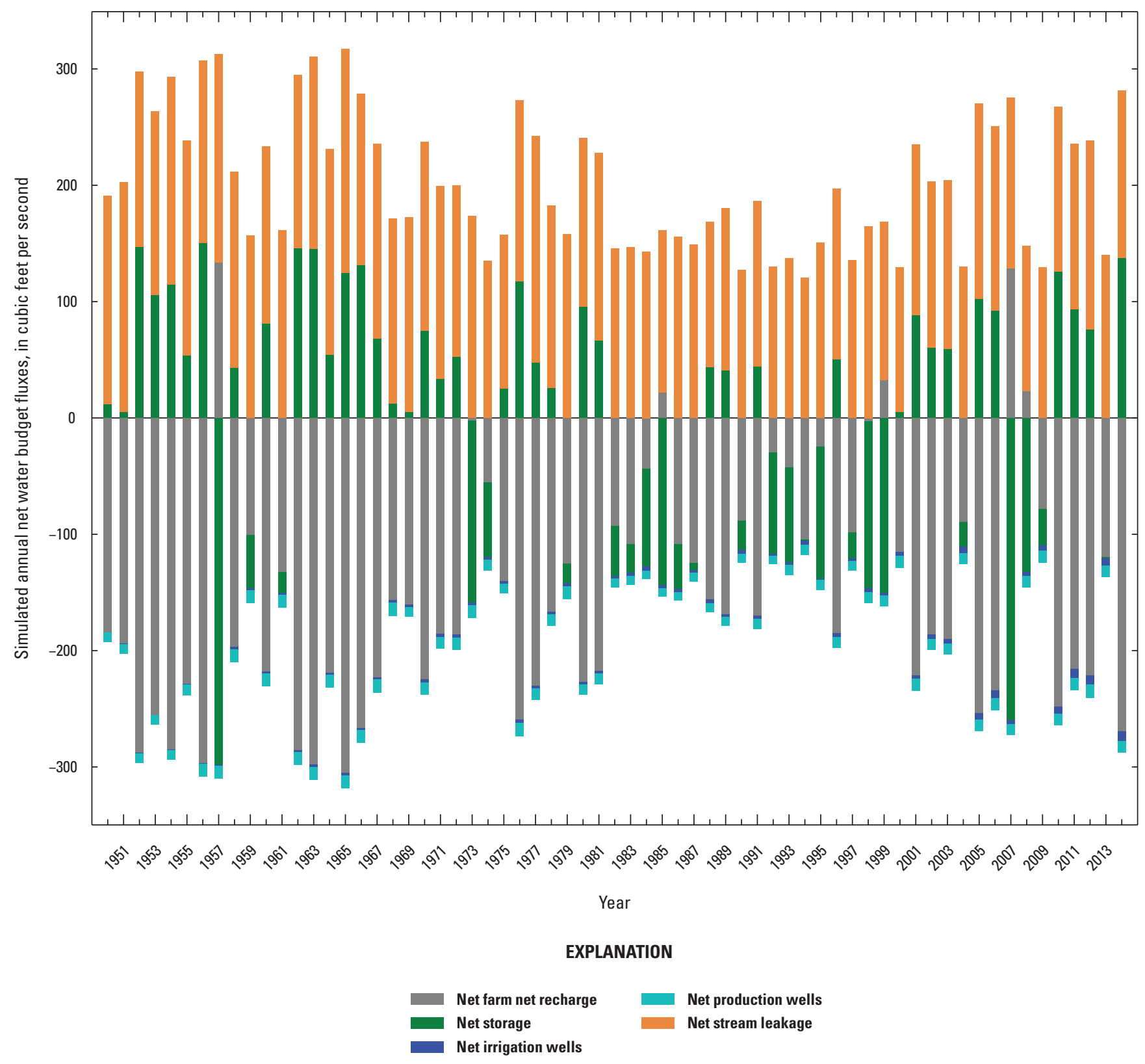

Figure 22. Simulated annual net groundwater-flow budget component fluxes for the Osage Nation Integrated Hydrologic Model from January 1950 to September 2014. 

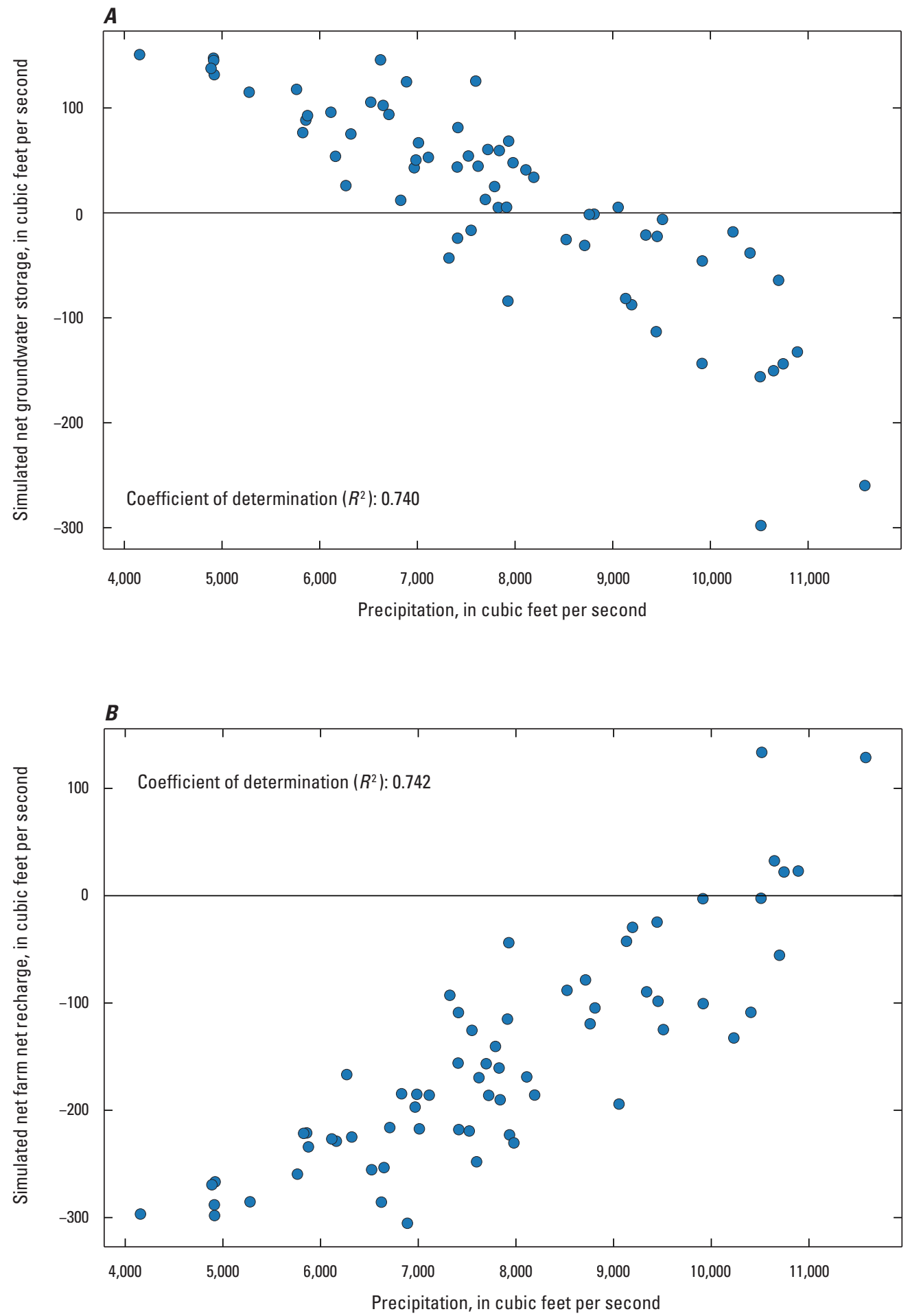

Figure 23. Linear regression of precipitation correlation to simulated net groundwater storage and net farm net recharge for the Osage Nation Integrated Hydrologic Model from January 1950 to September 2014. $A$, net groundwater storage; and $B$, net farm net recharge. 
Table 11. Simulated groundwater-flow budget average annual fluxes by supergroup for the Osage Nation Integrated Hydrologic Model from January 1950 to September 2014.

[Negative fluxes indicate a loss of water from the groundwater-flow system; positive fluxes indicate a gain of water to the groundwater-flow system; intersupergroup flow, the flux of groundwater into (positive value) or out of (negative value) a supergroup; $\mathrm{ft}^{3} / \mathrm{s}$, cubic foot per second; NA, not applicable]

\begin{tabular}{|c|c|c|c|c|c|c|c|c|}
\hline $\begin{array}{l}\text { Super- } \\
\text { group }\end{array}$ & Supergroup name & $\begin{array}{c}\text { Area } \\
\text { (acres) }\end{array}$ & $\begin{array}{c}\text { Net } \\
\text { Storage } \\
\left(\mathrm{ftt}^{3} / \mathbf{s}\right)\end{array}$ & $\begin{array}{c}\text { Net stream } \\
\text { leakage } \\
\left(\mathrm{ft}^{3} / \mathrm{s}\right)\end{array}$ & $\begin{array}{c}\text { Net } \\
\text { production } \\
\text { wells } \\
\left(\mathrm{ft}^{3} / \mathbf{s}\right)\end{array}$ & $\begin{array}{c}\text { Net } \\
\text { irrigation } \\
\text { wells } \\
\left(\mathrm{ft}^{3} / \mathbf{s}\right)\end{array}$ & $\begin{array}{c}\text { Net farm } \\
\text { net } \\
\text { recharge } \\
\left(\mathrm{ft}^{3} / \mathrm{s}\right)\end{array}$ & $\begin{array}{l}\text { Intersuper- } \\
\text { group flow } \\
\left(\mathrm{ft}^{3} / \mathrm{s}\right)\end{array}$ \\
\hline 1 & Bird Creek & 212,827 & -0.7 & 0.8 & 0.0 & 0.0 & 0.6 & -0.4 \\
\hline 2 & Salt Creek & 178,548 & -1.0 & 2.0 & 0.0 & 0.0 & 0.4 & -1.4 \\
\hline 3 & Sand Creek & 154,115 & -0.5 & -4.5 & 0.0 & 0.0 & 4.2 & 0.8 \\
\hline 4 & Arkansas River above Kaw Lake & 140,751 & -0.2 & 35.8 & -0.1 & -0.2 & -30.4 & -5.0 \\
\hline 5 & Arkansas River below Kaw Lake & 481,401 & 15.1 & 118.3 & -9.3 & -2.7 & -128.1 & 8.0 \\
\hline 6 & Deciduous forest & 514,177 & 8.3 & 31.1 & -2.7 & 0.0 & -50.6 & 14.2 \\
\hline 7 & Pasture & $1,140,322$ & 14.1 & 4.9 & -1.2 & -1.1 & 10.9 & -27.4 \\
\hline 8 & Central Osage & 133,793 & 1.8 & -3.3 & 0.0 & 0.0 & 4.9 & -3.4 \\
\hline 9 & Hominy Creek above Skiatook Lake & 242,835 & 2.3 & 0.8 & 0.0 & 0.0 & -1.6 & -1.5 \\
\hline 10 & Hominy Lake supply & 3,716 & 0.3 & 0.1 & 0.0 & 0.0 & 0.3 & -0.7 \\
\hline 11 & Burbank Oil Field & 46,574 & -0.8 & -1.2 & 0.0 & 0.0 & 1.7 & 0.2 \\
\hline \multirow[t]{2}{*}{12} & Naval Reserves & 22,773 & 0.2 & 0.0 & 0.0 & 0.0 & 1.0 & -1.2 \\
\hline & Total model area & $1,858,905$ & 14.7 & 152.5 & -9.4 & -2.8 & -153.4 & NA \\
\hline
\end{tabular}

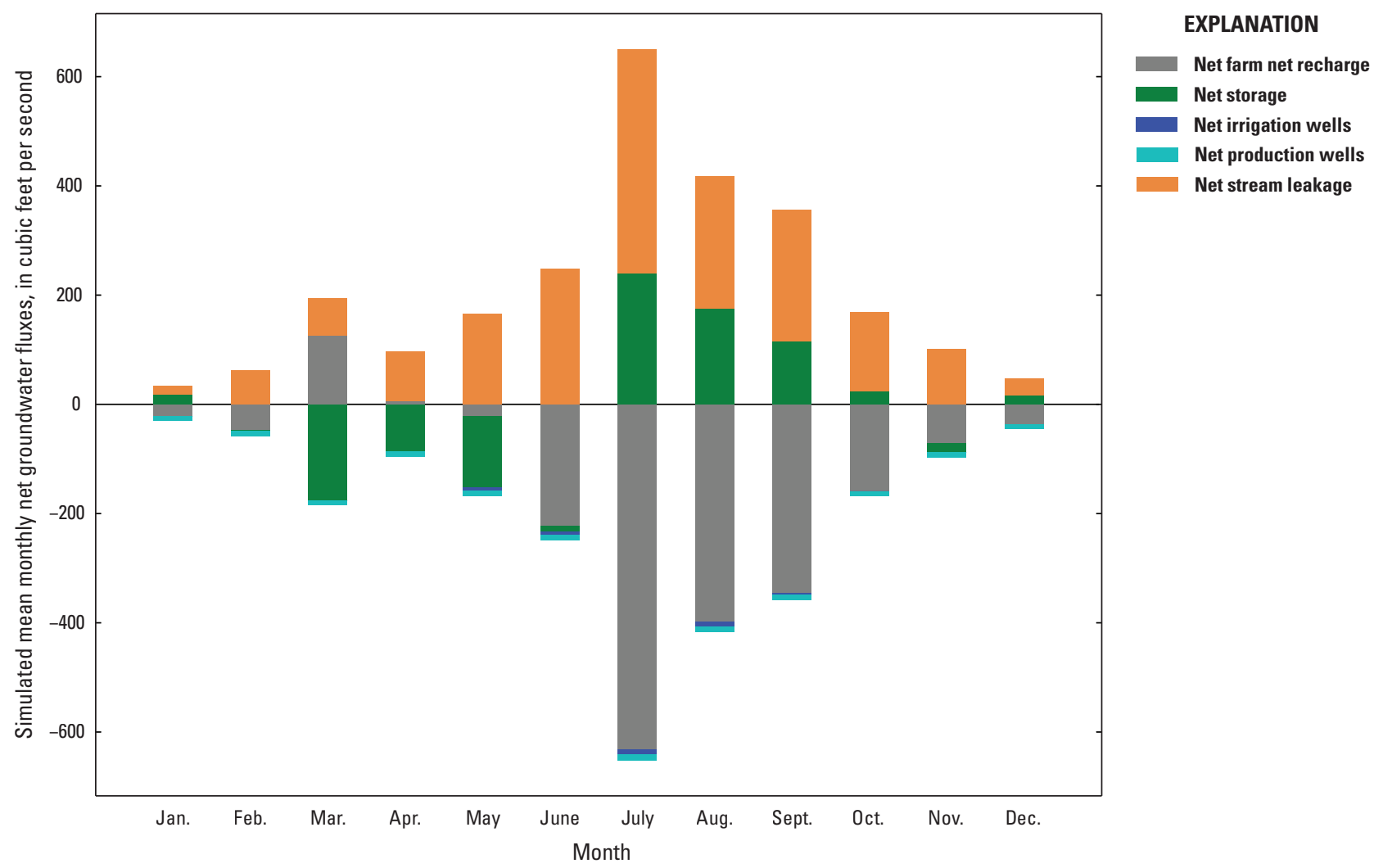

Figure 24. Simulated mean monthly net groundwater fluxes for the Osage Nation Integrated Hydrologic Model from January 1950 to September 2014. 
monthly flux of $56 \mathrm{ft}^{3} / \mathrm{s}$, whereas during the growing season months (April through October), the mean monthly flux was $220 \mathrm{ft}^{3} / \mathrm{s}$ (fig. 24). The positive mean monthly stream leakage for each month indicated that the overall stream system is naturally a "losing" system all year long and the magnitude of stream leakage is driven by changes in ET from groundwater throughout the year. It should be noted that higher stream stages that result from higher streamflows can increase the difference between the hydraulic head in the stream and the groundwater, that can cause an increase in stream leakage. However, the magnitude of simulated stream leakage in the ONIHM is driven by ET of groundwater because the largest mean monthly groundwater ET rates occurred in July, August, and September (fig. 24) while the largest streamflows occurred in April, May, and June, when precipitation was highest. The overall "losing" system simulated in the ONIHM is consistent with the conceptual model and base-flow analysis for the parts of the Arkansas River, but it is a deviation from the conceptual model for other parts of the Arkansas River and most smaller streams that demonstrated gaining conditions defined by groundwater discharge to the stream as base flow in the baseflow analysis (table 1). The streams with "gaining" systems in the ONIHM were those with negative net stream leakage values; they were streams in the Sand Creek, Central Osage, and Burbank Oil Field supergroups (table 11). Streams in the other nine supergroups, with positive net stream leakage values, demonstrated "losing" stream systems (table 11). The simulated stream leakage deviation from the conceptual model for of the streams within most of the "losing" system supergroups (Bird Creek, Salt Creek, and Hominy Creek above Skiatook Lake) is likely a result of the bias in model-simulated groundwater levels that were lower than their measured equivalent values (tables 5 and 11). The artificially low groundwater levels resulted in a higher stream stage than the surrounding groundwater levels and therefore, in ONIHM, induced infiltration of the stream water back into the aquifer. The model results did demonstrate monthly trends in stream leakage that indicated ET affected the surrounding groundwater levels and the gain or losing regime of the stream.

\section{Supergroup Landscape and Groundwater-Flow Budgets}

Landscape and groundwater-flow budgets were created for each of the 12 supergroups in the ONIHM (fig. 8). Magnitudes of each landscape and groundwater-flow budget component varied across supergroups (table 10); however, there were noteworthy similarities across supergroups. The annual landscape water budgets for all 12 supergroups showed similar trends to the landscape water budget for the active model area. $\mathrm{P}_{\text {land }}$ and $\mathrm{Tp}$ were the predominant inflow and outflow components for all supergroups, respectively. Together, Ep and Tp (ETp) were the dominant outflow from the landscape in all supergroups (table 10). The supergroups with the highest percentage (Burbank Oil Field, Naval Reserves, and Pasture) of ETp in relation to precipitation were those with more pasture land use, and conversely, supergroups with less pasture and more deciduous forest land use (Deciduous forest and Sand Creek) had lower percentages of ETp in relation to precipitation. The supergroups with higher amounts of pasture (Pasture, Salt Creek, Central Osage, Burbank Oil Field, and Naval Reserves) also demonstrated less runoff and deep percolation than other supergroups because more precipitation was consumed by ET (table 10). RO also was a substantial outflow component (9.2 to 15.8 percent of $\mathrm{P}_{\text {land }}$ ) of the landscape water budget for all supergroups. Of the supergroups in the central or eastern part of the study area, four (Salt Creek, Sand Creek, Central Osage, Hominy Lake supply, and Naval Reserves) demonstrated no substantial Tgw or Egw outflows, which correlated with slightly losing or partially gaining stream systems rather than strongly losing streams.

Magnitudes of each component varied among the individual groundwater-flow budgets for the 12 supergroups on an annual basis. Groundwater-flow budgets for Bird Creek, Salt Creek, and Hominy Creek above Skiatook Lake demonstrated minimal net fluxes of storage and stream leakage (Salt Creek had a small net outflow of storage of $1.0 \mathrm{ft}^{3} / \mathrm{s}$ ) and net outflows of farm net recharge and groundwater flow to adjacent areas (table 11).

The groundwater-flow budget components for these supergroups demonstrated similar behavior and magnitude because they were focused on streams that originated in the central part of the model and flowed from west to east over the same model layers. Groundwater-flow budget components for the Arkansas River above Kaw Lake, Arkansas River below Kaw Lake, and Deciduous forest supergroups demonstrated similar inflows and outflows. These supergroups were characterized by large net inflows from stream leakage, lesser net inflows from storage, large net outflows to farm net recharge, and small net outflows to production wells and irrigation wells. These supergroups demonstrated similar behavior among the groundwater-flow budget components because between 14 and 29 percent the land use in the Arkansas River Basin was deciduous forest; Deciduous forest supergroup accounted for about 27 percent of the land use. The deciduous forest also played an important role in the behavior of the Arkansas River system throughout the year. The groundwater consumed by the deciduous forest through ET affected the stream leakage from month to month. During the nongrowing season months of November through March, when trees were dormant and groundwater ET was low, the Arkansas River below Kaw Lake mean monthly stream leakage outflow was $63 \mathrm{ft}^{3} / \mathrm{s}$ and the growing season (April through October) mean was $172.6 \mathrm{ft}^{3} / \mathrm{s}$ (fig. 25). Additionally, almost all the active public supply, industrial, and irrigation wells in the model existed in the Arkansas River alluvium between Kaw Lake and Keystone Lake, and as a result, the Arkansas River below Kaw Lake supergroup demonstrated the largest net outflows of groundwater pumping for supergroups with pumping from 


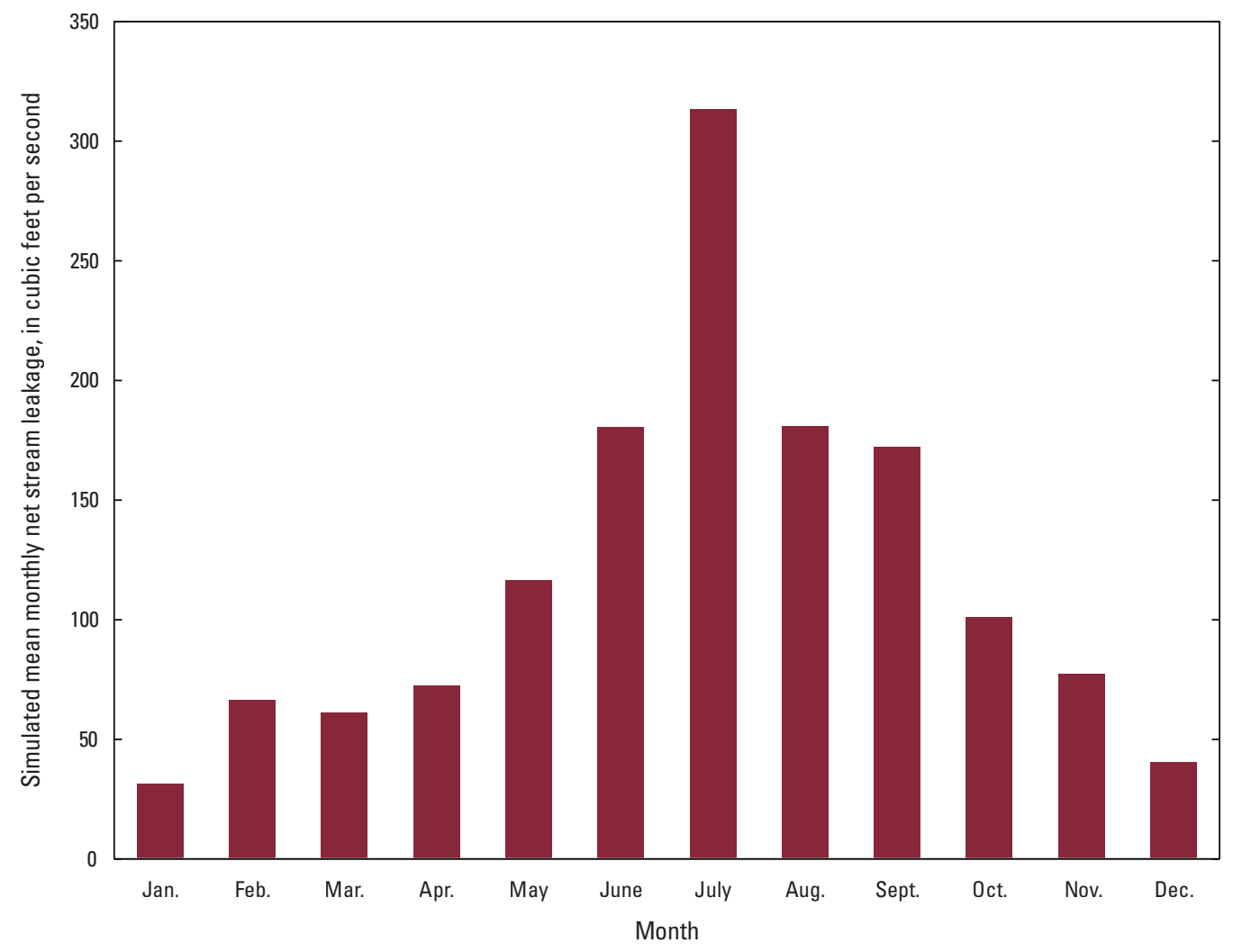

Figure 25. Simulated mean monthly net stream leakage for the Arkansas River below Kaw Lake supergroup for the Osage Nation Integrated Hydrologic Model from January 1950 to September 2014. wells. Although the two Arkansas River supergroup groundwater-flow budgets shared many similarities, a key difference was the groundwater flow to adjacent supergroups. The Arkansas River above Kaw Lake demonstrated an annual mean net outflow of groundwater to adjacent zones of about $5 \mathrm{ft}^{3} / \mathrm{s}$, whereas the Arkansas River below Kaw Lake demonstrated mean annual net inflows of groundwater from adjacent zones of about $8 \mathrm{ft}^{3} / \mathrm{s}$ (table 11).

The individual groundwater-flow budgets differed for the deciduous forest and pasture supergroups (table 11). The main difference was the net farm net recharge component: deciduous forest demonstrated a mean annual outflow of $50.6 \mathrm{ft}^{3} / \mathrm{s}$ and pasture demonstrated a mean annual inflow of $10.9 \mathrm{ft}^{3} / \mathrm{s}$. Deciduous forest primarily resided in stream valleys with shallow water tables; in contrast, pasture was primarily in the plains regions that did not experience much groundwater uptake by roots. The large outflow of net farm net recharge as groundwater ET for deciduous forest also affected the stream leakage component, which had an inflow of $31.1 \mathrm{ft}^{3} / \mathrm{s}$, compared to pasture, which had an inflow of $4.9 \mathrm{ft}^{3} / \mathrm{s}$. Mean annual net storage of groundwater was similar for both supergroups, with inflows of $8.3 \mathrm{ft}^{3} / \mathrm{s}$ and $14.1 \mathrm{ft}^{3} / \mathrm{s}$ for deciduous forest and pasture, respectively. The large discrepancy in outflows from stream leakage between the two supergroups, while maintaining almost identical net inflows to storage, was due to the net groundwater flow to adjacent zones: deciduous forest had a $14.2-\mathrm{ft}^{3} / \mathrm{s}$ mean annual inflow from adjacent zones, whereas pasture had a $27.4-\mathrm{ft}^{3} / \mathrm{s}$ mean annual outflow to adjacent zones.

\section{Climate-Based Landscape Water Budgets}

The landscape water budget components were grouped by dry, average, and wet years of the 1950-2014 period based on annual precipitation to assess the behavior and trends of each component with respect to different periods of precipitation. Dry, average, and wet years corresponded to annual precipitation amounts of less than the 25 th percentile (31.19 in.), from the 25 th to the 75 th percentile (31.19 to $42.76 \mathrm{in}$.), and greater than the 75 th percentile (42.76 in.), respectively; described in the "Physiography and Climate" section. Sixteen years were classified as "dry," 31 years classified as "average," and 16 classified as "wet," from 1950 to 2014.

Landscape component fluxes demonstrated trends that correlated to precipitation. Mean annual Ep, Tp, RO, and DP were smallest for dry years and largest for wet years, and inversely, Egw and Tgw were largest for dry years and smallest for wet years. These trends are typical for a landscape system that depends on rainfall where increased precipitation results in increased plant activity via ET, runoff, and deep percolation or recharge past the root zone (table 12).

Irrigation wells did not demonstrate a similar trend to the other components because their largest mean annual flux $\left(3.0 \mathrm{ft}^{3} / \mathrm{s}\right)$ occurred during average conditions. It was expected that the largest irrigation demands would be met during the driest years; however, this was not the case. Ti also had a larger flux for average years than dry years. The higher irrigation values in average conditions compared to dry conditions 
Table 12. Simulated mean annual landscape water budget component fluxes for all, dry, average, and wet years for the Osage Nation Integrated Hydrologic Model from January 1950 to September 2014.

[Negative fluxes indicate the removal of water from the landscape; positive fluxes indicate an addition of water to the landscape]

\begin{tabular}{|c|c|c|c|c|c|c|c|c|c|c|}
\hline \multirow[b]{2}{*}{$\begin{array}{l}\text { Climate } \\
\text { period }\end{array}$} & \multicolumn{10}{|c|}{ Mean landscape water budget component values, in cubic feet per second } \\
\hline & $\begin{array}{c}\text { Precipitation } \\
\left(\mathbf{P}_{\text {land }}\right)\end{array}$ & $\begin{array}{l}\text { Irrigation } \\
\text { wells } \\
\left(\text { Irr }_{\text {wells }}\right)\end{array}$ & $\begin{array}{c}\text { Evaporation from } \\
\text { groundwater } \\
\text { (Egw) }\end{array}$ & $\begin{array}{l}\text { Transpiration from } \\
\text { ground water } \\
\text { (Tgw) }\end{array}$ & $\begin{array}{l}\text { Evaporation from } \\
\text { irrigation water } \\
\text { (Ei) }\end{array}$ & $\begin{array}{l}\text { Evaporation from } \\
\text { precipitation } \\
\text { (Ep) }\end{array}$ & $\begin{array}{l}\text { Transpiration from } \\
\text { irrigation water } \\
\text { (Ti) }\end{array}$ & $\begin{array}{l}\text { Transpiration from } \\
\text { precipitation } \\
\text { (Tp) }\end{array}$ & $\begin{array}{c}\text { Runoff } \\
\text { (RO) }\end{array}$ & $\begin{array}{l}\text { Deep } \\
\text { percolation } \\
\text { (DP) }\end{array}$ \\
\hline All years & $7,820.2$ & 2.8 & -237.0 & -70.2 & -0.2 & $-1,641.1$ & -2.2 & $-5,032.1$ & -998.4 & -148.9 \\
\hline Dry & $5,649.8$ & 2.6 & -238.5 & -76.2 & -0.2 & $-1,259.7$ & -2.0 & $-3,931.2$ & -398.5 & -60.9 \\
\hline Average & $7,714.0$ & 3.0 & -234.1 & -68.0 & -0.2 & $-1,651.4$ & -2.3 & $-5,084.4$ & -850.4 & -128.2 \\
\hline Wet & $10,187.0$ & 2.5 & -239.1 & -69.1 & -0.1 & $-1,993.5$ & -2.0 & $-6,048.4$ & $-1,870.0$ & -275.4 \\
\hline
\end{tabular}


resulted from differences in the monthly precipitation trends. Dry months (precipitation less than $1.37 \mathrm{in} . /$ month or less than the 25th percentile of monthly precipitation) only occurred in the winter months of January, February, and December which indicated that if there was a dry year, it was dry during the winter or the nongrowing season. Average months (precipitation between $1.37 \mathrm{in} . / \mathrm{month}$ and $4.25 \mathrm{in} . / \mathrm{month}$, or the middle 50th percentile of monthly precipitation) only occurred in March, April, July, August, October, and November which indicated that average years were based on the precipitation in the growing season months. Wet months (precipitation greater than $4.25 \mathrm{in} . / \mathrm{month}$, or the greater than the 75 th percentile of monthly precipitation) only occurred in May, June, and September which indicated that wet years were based on the precipitation in the growing season months, like the average conditions. The dry years did not have excessively dry growing seasons which resulted in less irrigation required than in average years. Irrigation flux was lowest for the wet years because a wet year occurred if the growing season was wet. This demonstrate that irrigation requirements and subsequent pumping are driven by the climate during the growing season.

\section{Climate-Based Groundwater-Flow Budgets}

Like the landscape water budget components, the groundwater-flow budget components were grouped by dry, average, and wet years of the 1950-2014 period based on annual precipitation to assess the behavior and trends of each component with respect to different periods of precipitation. Dry, average, and wet years corresponded to annual precipitation amounts described in the "Climate-Based Landscape Water Budgets" section of this report.

Groundwater fluxes demonstrated similar trends for the dry and average climate periods that were characterized by inflows to the groundwater-flow system from storage and from stream leakage. These inflows for the dry and average climate corresponded to decreasing groundwater levels and "losing" streams throughout the simulations. Conversely, the wet climate period was characterized by outflows from the groundwater-flow system to storage throughout the simulation, which resulted in increasing groundwater levels. The Arkansas
River above and below Kaw Lake was a "losing" stream for all climate periods, whereas Bird Creek was a "losing" stream for the dry and average climate periods and a "gaining" stream for the wet climate period.

Dry years demonstrated the largest inflows to net storage and net stream leakage and the largest net outflows were from production and irrigation wells and farm net recharge (table 13). The 16 wet years were characterized by net inflows from stream leakage each year $\left(148 \mathrm{ft}^{3} / \mathrm{s}\right)$ and net outflows of farm net recharge for 14 years $\left(-43 \mathrm{ft}^{3} / \mathrm{s}\right)$. Net storage was an outflow (replenishment of storage from the groundwater-flow system) for each of the 16 wet years which demonstrated that groundwater-levels increased during every wet year simulated in the ONIHM. Production and irrigation wells remained net outflows each wet year because they cannot be sources of water, only sinks that remove water from the groundwaterflow system.

\section{Fresh/Marginal Groundwater and Saline Groundwater}

The fresh/marginal groundwater availability in the study area was assessed by calculating the saturated thickness of the fresh/marginal groundwater as the difference between the final stress period (September 2014) water table and the base of marginal groundwater (fig. 26). The average fresh/marginal groundwater saturated thickness for the active area of the ONIHM was $134.6 \mathrm{ft}$, ranging from 0 to $438.2 \mathrm{ft}$, and the average thickness of saline groundwater was $1,043 \mathrm{ft}$, ranging from 380.3 to $1,826.6 \mathrm{ft}$, respectively (table 14 ). Although about 91 percent of the study area had at least some saturated thickness of fresh/marginal groundwater, the saturated thickness and occurrence of fresh/marginal groundwater varied widely across the study area. Within each supergroup, the fresh/marginal groundwater constituted between about 2 and 32 percent of the total saturated thickness (table 14). Of the 12 supergroups, 11 had at least 1 model cell area (40 acres) with no fresh/marginal groundwater (table 14). Several areas of the ONIHM active model demonstrated substantial extents of no saturated thickness, which included the northern and southern

Table 13. Simulated mean annual net groundwater-flow component fluxes for all, dry, average, and wet years for the Osage Nation Integrated Hydrologic Model from January 1950 to September 2014.

[Negative fluxes indicate a loss of water from the groundwater-flow system; positive fluxes indicate a gain of water to the groundwater-flow system; $\mathrm{ft}^{3} / \mathrm{s}$, cubic foot per second]

\begin{tabular}{|c|c|c|c|c|c|}
\hline Climate period & $\begin{array}{c}\text { Net storage } \\
\left(\mathrm{ft}^{3} / \mathrm{s}\right)\end{array}$ & $\begin{array}{c}\text { Net stream leakage } \\
\left(\mathrm{ft}^{3} / \mathrm{s}\right)\end{array}$ & $\begin{array}{l}\text { Net production wells } \\
\left(\mathrm{ft}^{3} / \mathrm{s}\right)\end{array}$ & $\begin{array}{l}\text { Net irrigation wells } \\
\left(\mathrm{ft}^{3} / \mathrm{s}\right)\end{array}$ & $\begin{array}{c}\text { Net farm net recharge } \\
\left(\mathrm{ft}^{3} / \mathrm{s}\right)\end{array}$ \\
\hline All years & 14.7 & 152.5 & -9.4 & -2.8 & -153.4 \\
\hline Average & 30.0 & 152.2 & -9.3 & -3.0 & -168.2 \\
\hline Wet & -106.3 & 148.0 & -9.1 & -2.5 & -26.8 \\
\hline
\end{tabular}




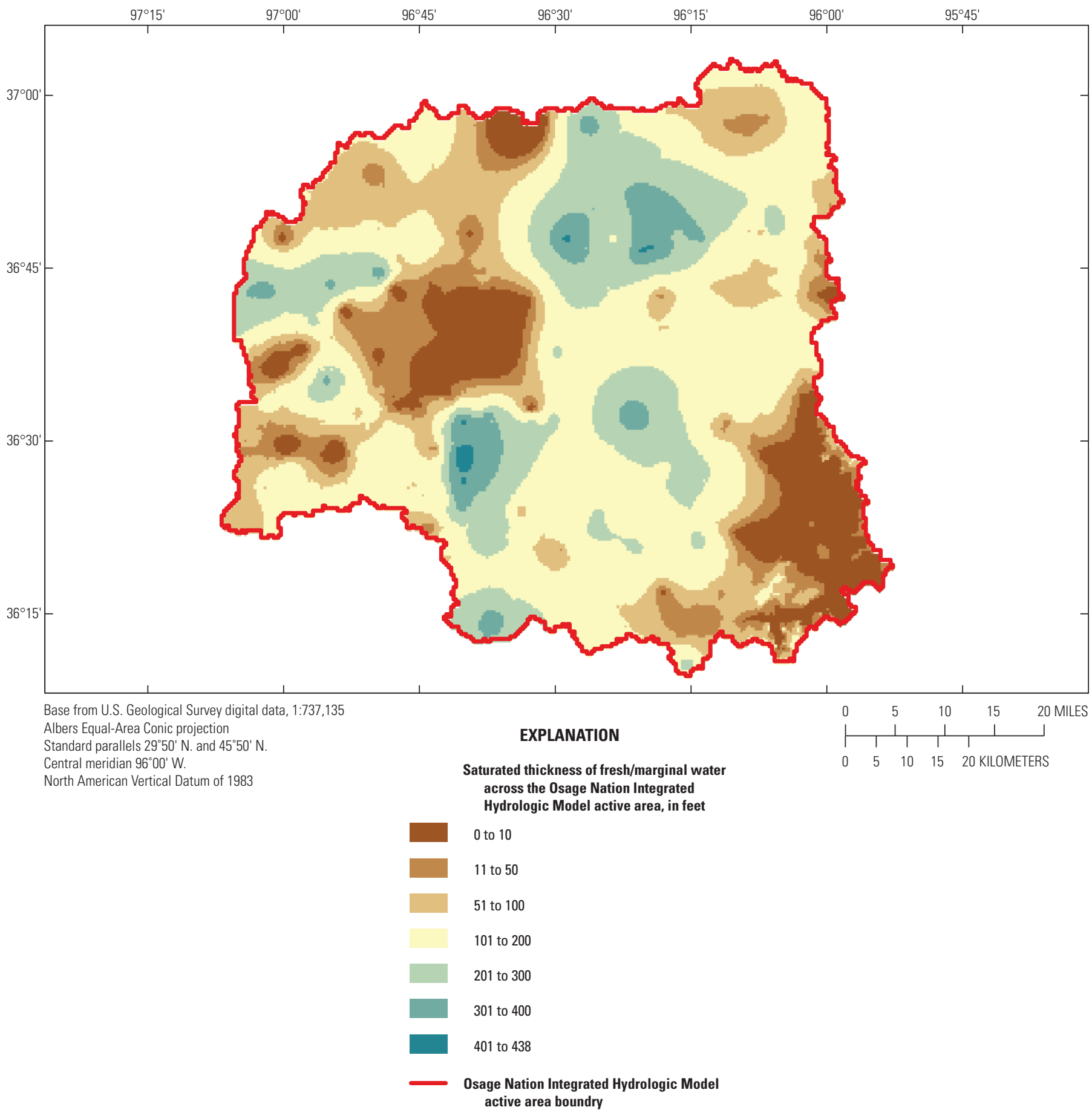

Figure 26. The simulated saturated thickness of fresh/marginal groundwater across the Osage Nation Integrated Hydrologic Model active area at the end of the 1950-2014 period (September 30, 2014). 
Table 14. Percentage of deciduous forest and pasture land use; simulated minimum, average, and maximum saturated thickness of fresh/marginal groundwater; and average saturated thickness of saline groundwater by supergroup for the Osage Nation Integrated Hydrologic Model from January 1950 to September 2014.

[ft, foot; thickness, in percent, percentage of total saturated thickness that is fresh/marginal groundwater calculated as follows: average thickness of fresh/marginal groundwater divided by (average thickness of fresh/marginal groundwater + average thickness of saline groundwater) multiplied by 100]

\begin{tabular}{|c|c|c|c|c|c|c|c|}
\hline \multirow[b]{2}{*}{ Supergroup } & \multirow{2}{*}{$\begin{array}{l}\text { Deciduous forest, } \\
\text { in percent }\end{array}$} & \multirow{2}{*}{$\begin{array}{l}\text { Pasture, } \\
\text { in percent }\end{array}$} & \multicolumn{4}{|c|}{$\begin{array}{l}\text { Saturated thickness of fresh/marginal } \\
\text { groundwater }\end{array}$} & \multirow{2}{*}{$\begin{array}{c}\text { Average thickness } \\
\text { of saline } \\
\text { groundwater } \\
\text { (ft) }\end{array}$} \\
\hline & & & $\begin{array}{l}\text { Minimum } \\
\text { thickness } \\
\text { (ft) }\end{array}$ & $\begin{array}{c}\text { Average } \\
\text { thickness } \\
\text { (ft) }\end{array}$ & $\begin{array}{l}\text { Maximum } \\
\text { thickness } \\
\text { (ft) }\end{array}$ & $\begin{array}{l}\text { Thickness, } \\
\text { in percent }\end{array}$ & \\
\hline Bird Creek & 31.1 & 64.7 & 0.0 & 127.2 & 422.6 & 21.8 & 456.5 \\
\hline Salt Creek & 4.4 & 88.8 & 0.0 & 47.6 & 310.3 & 2.9 & $1,620.8$ \\
\hline Sand Creek & 38.2 & 58.4 & 0.0 & 182.9 & 407.2 & 32.5 & 380.2 \\
\hline Arkansas River above Kaw Lake & 14.1 & 65.6 & 0.0 & 124.6 & 387.1 & 6.4 & $1,826.6$ \\
\hline Arkansas River below Kaw Lake & 28.6 & 51.7 & 0.0 & 141.4 & 438.2 & 8.5 & $1,527.6$ \\
\hline Deciduous forest & 100.0 & 0.0 & 0.0 & 130.4 & 437.5 & 16.5 & 657.7 \\
\hline Pasture & 0.0 & 100.0 & 0.0 & 134.6 & 438.2 & 11.5 & $1,035.2$ \\
\hline Central Osage & 20.2 & 77.9 & 0.0 & 177.0 & 438.2 & 15.0 & $1,001.1$ \\
\hline Hominy Creek above Skiatook Lake & 36.8 & 56.2 & 0.0 & 143.4 & 377.6 & 23.3 & 472.2 \\
\hline Hominy Lake supply & 26.0 & 68.5 & 176.3 & 195.6 & 211.4 & 22.2 & 684.0 \\
\hline Burbank Oil Field & 4.6 & 89.1 & 0.0 & 43.7 & 162.4 & 2.5 & $1,723.4$ \\
\hline Naval Reserves & 8.7 & 91.0 & 0.0 & 166.8 & 317.1 & 12.8 & $1,131.8$ \\
\hline
\end{tabular}

regions of the Salt Creek supergroup, the southeasternmost region of the Bird Creek supergroup, and western regions of the Arkansas River below Kaw Lake supergroup (fig. 26). The Salt Creek and Burbank Oil Field supergroups demonstrated the lowest average thickness of fresh/marginal groundwater (47.6 and $43.7 \mathrm{ft}$ ) and the lowest percentage of fresh/marginal groundwater (2.9 and 2.5 percent; table 14). The Sand Creek supergroup demonstrated the highest percentage (32.5 percent) of fresh/marginal groundwater, and the Hominy Lake supply supergroup demonstrated the largest average saturated thickness of fresh/marginal groundwater (195.6 ft; table 14), although the Hominy Lake supply supergroup has the smallest areal extent of all the supergroups (table 11).

\section{Forecast Water Availability}

The calibrated 1950-2014 period ONIHM simulated three forecasts to assess the effects of potential climatic changes on the hydrologic system from October 2014 to December 2099. The three forecasts simulated theoretical dry, average, and wet conditions using precipitation and PET datasets from selected years in the calibrated 1950-2014 period ONIHM. The forecasts will be referred to as "DRY," "AVG" (average), or "WET" for the remainder of the report. A total of 1 year (12 stress periods) of precipitation and PET data were selected from a dry, average, or wet year in the calibrated 1950-2014 period ONIHM and repeated for each year of the
85 years of forecast simulations. The 2013 land-use dataset was repeated for all years of the forecasts; 2013 was selected because growing season and nongrowing season data were available from the calibrated 1950-2014 period ONIHM in 2013, but 2014 did not have October through December data, and there was not a substantial difference between 2013 and 2014 land-use trends. The selected precipitation data, PET data, and land-use data for each year of the forecasts were repeated to assess end member results and trends. The years of data from the calibrated 1950-2014 period ONIHM selected to represent dry, average, and wet conditions in the forecasts were 1976, 2010, and 2008, respectively, and were based on the lowest mean monthly $R^{2}$ values of precipitation for three quartile ranges (dry: less than the 25th percentile, average: from the 45th to the 55th percentile, and wet: greater than the 75 th percentile) of annual precipitation. This selection process was used to select a year of precipitation data that closely matched the average monthly trends for the specific condition and to avoid years that contained months with extreme precipitation values in addition to selecting a year with the proper amount of annual precipitation that represented the desired conditions. Annual precipitation amounts were 26.89, 35.47, and 50.73 in. for the DRY, AVG, and WET forecasts, respectively. The 2015 to 2099 outputs were used to calculate the changes from the beginning of the forecast simulation to the end of the forecast simulation because 2015 was the first full year of outputs and could be directly compared to 2099 outputs, which also are a full year. 


\section{Landscape Water Budget}

Individual magnitudes of landscape water budget fluxes for the three forecasts were driven by the precipitation, PET, and land-use inputs, which were constant values for each forecast period. The largest flux for the landscape for each forecast was inflows from precipitation. The largest outflow fluxes were from Tp with mean annual fluxes of $4,429 \mathrm{ft}^{3} / \mathrm{s}$ (21 in/yr); 5,560 ft3 $/ \mathrm{s}(26 \mathrm{in} / \mathrm{yr})$; and 6,289 ft $\mathrm{ft}^{3} / \mathrm{s}$ (30 in/yr) for the DRY, AVG, and WET forecasts, respectively (table 15). ET from precipitation (sum of Tp and Ep) consumed about 95, 95, and 77 percent of precipitation for the DRY, AVG, and WET forecasts, respectively (table 16). Runoff was the second largest consumer of precipitation for the three forecasts $(4.0,4.6$, and 20.1 percent; table 16). Mean annual outflows to runoff for DRY, AVG, and WET forecasts were $226 \mathrm{ft}^{3} / \mathrm{s}$ ( $1 \mathrm{in} / \mathrm{yr}$ ), $348 \mathrm{ft}^{3} / \mathrm{s}(1.6 \mathrm{in} / \mathrm{yr})$, and 2,160 ft 3 /s (10.2 in/yr). DRY and AVG runoff occurred almost evenly throughout the growing season months, but WET runoff occurred predominantly in February through June (fig. 27A-C). Deep percolation was minimal for each forecast: the DRY forecast for deep percolation was $38 \mathrm{ft}^{3} / \mathrm{s}(0.18 \mathrm{in} / \mathrm{yr})$, the AVG forecast for deep percolation was $56 \mathrm{ft}^{3} / \mathrm{s}(0.26 \mathrm{in} / \mathrm{yr})$, and the WET forecast for deep percolation was $310 \mathrm{ft}^{3} / \mathrm{s}$ (1.46 in/yr), and most of the WET deep percolation occurred during the wettest months of March through June (fig. 27A-C).

Landscape fluxes did not vary substantially from year to year because of the constant inputs, but the forecast simulations from 2015 to 2099 demonstrated small trends. The most substantial trends for the forecasts were for Tgw. DRY and AVG Tgw demonstrated decreases of 25 and 22 percent, respectively, from 2015 to 2099, and the WET forecast Tgw demonstrated an increase of 44 percent for the same period. Egw changed by 7 percent, 4 percent, and -21 percent for the DRY, AVG, and WET forecasts, respectively, from 2015 to 2099. The Egw and Tgw, as mentioned previously, are hybrid budget components that involve the landscape and groundwater-flow systems. The primary landscape water budget components (Ei, Ep, Ti, Tp, RO, and DP) did not vary as much as the Egw and Tgw components. RO and DP varied less than 5 percent of all forecasts. RO and DP decreased for the DRY and AVG forecasts and increased for the WET forecast from 2015 to 2099.

A comparison of the landscape water budget components indicated that runoff demonstrated the largest change from one forecast to another. Runoff increased by 54 percent between the DRY and AVG forecasts and increased by 521 percent between the AVG and WET forecasts. At the same time, ET of precipitation only increased 31 percent $\left(-5,437\right.$ to $\left.-7,118 \mathrm{ft}^{3} / \mathrm{s}\right)$ from DRY to AVG and 17 percent $\left(-7,118\right.$ to $\left.-8,298 \mathrm{ft}^{3} / \mathrm{s}\right)$ from AVG to WET (table 15). The smaller increase in ET from the AVG to WET indicated that ET for the WET forecast approached the PET limit at which point plants could not ET additional precipitation.

\section{Groundwater-Flow Budget}

Individual magnitudes of groundwater-flow budget fluxes varied for each of the three forecasts. All forecasts were characterized by positive net stream leakage for all stress periods, which indicated that the overall stream network in the ONIHM persists as a "losing" regime even under constant wet conditions. Mean annual net stream leakage rates for DRY, AVG, and WET forecasts were about 183, 181, and $103 \mathrm{ft}^{3} / \mathrm{s}$, respectively (table 17). The minimal change in mean annual net stream leakage rates from the DRY to AVG forecasts, in addition to the 43 percent decrease from the DRY and AVG forecasts to the WET forecast, indicate that the study area groundwater/surface-water interaction is more sensitive to wetter climate than drier climate (table 17). Monthly net stream leakage fluxes were generally highest during June through September for all three forecasts (fig. $28 A-C$ ), which corresponded to the peak of the growing season which indicated that on monthly time scales, stream leakage is sensitive to groundwater uptake by plant roots as they become more active during the growing season. Additionally, the WET forecast was the only forecast with months (January, April, and December) of mean monthly net stream leakage outflows, where outflows indicate a "gaining" regime when groundwater discharges to streams as base flow.

The DRY and AVG forecast fluxes demonstrated similar behavior for the simulation and were characterized by positive net storage for all stress periods and generally characterized by negative net farm net recharge, irrigation wells, and production wells (table 17). Mean annual net storage for the DRY and AVG forecasts was about 59 and $51 \mathrm{ft}^{3} / \mathrm{s}$, respectively. These fluxes were as much as four times greater than 1950-2014 period mean annual fluxes and corresponded to continuous decreases in streamflow and groundwater levels throughout the DRY and AVG forecast periods (table 13 and table 17). Large consecutive inflows from storage for the DRY and AVG forecasts occurred primarily from June through December (fig. 28A-C).

The WET forecast results demonstrated different behavior for some groundwater-flow budget components, characterized by negative net storage for all stress periods and positive net farm net recharge from 2015 to 2040 and negative values from 2041 to 2099 (fig. 29). Mean annual net storage for the WET forecast was about $-78 \mathrm{ft}^{3} / \mathrm{s}$ (table 17) and this storage occurred from February through June, which corresponded to the months when net farm net recharge was positive, indicating that deep percolation (recharge) was greater than the ET of groundwater. The monthly relation between negative net storage and positive net farm net recharge for all forecasts, but particularly the WET forecast, highlights the importance of the timing of recharge as it relates to ET, and more specifically groundwater ET. Under these theoretical forecasts, recharge and subsequent increasing water levels are more likely to occur during wetter than average months and early in the growing season when ET is not yet at full consumption (fig. 28C). 
Table 15. Summary of the simulated mean annual dry, average, and wet forecasts for the active model area and for each supergroup landscape water budget component and fluxes and percentage change from dry forecast for the Osage Nation Integrated Hydrologic Model.

[Negative fluxes indicate the removal of water from the landscape; positive fluxes indicate an addition of water to the landscape; DRY, dry forecast; \%, percent; NA, not applicable; AVG, average forecast; WET, wet forecast]

\begin{tabular}{|c|c|c|c|c|c|c|c|c|c|c|c|c|c|c|c|}
\hline 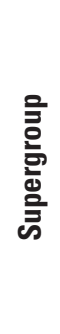 & Supergroup name & 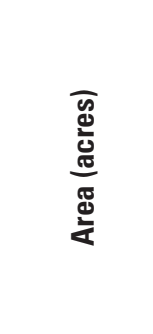 & 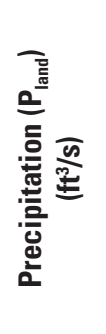 & 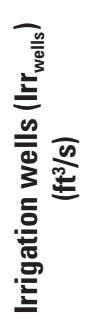 & 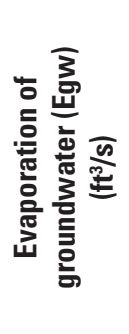 & 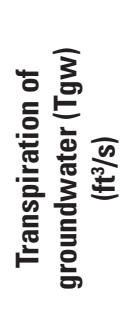 & 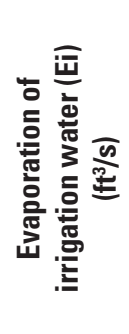 & 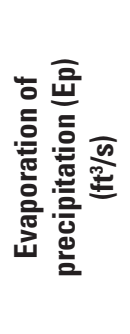 & 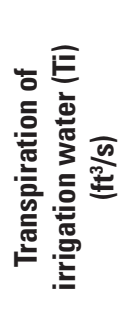 & 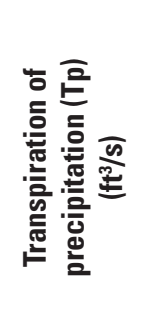 & 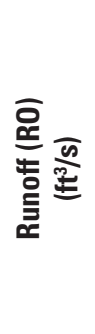 & 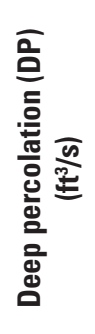 & 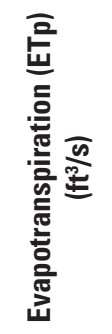 & 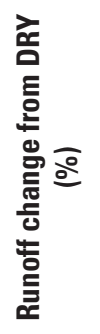 & 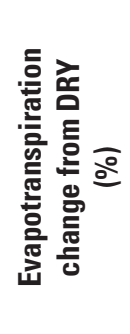 \\
\hline \multicolumn{16}{|c|}{ Mean annual net landscape fluxes for DRY } \\
\hline 1 & Bird Creek & 212,827 & 983 & 0 & -12 & -6 & 0 & -148 & 0 & -795 & -34 & -6 & -943 & NA & NA \\
\hline 2 & Salt Creek & 178,548 & 610 & 0 & -5 & -4 & 0 & -72 & 0 & -523 & -13 & -2 & -595 & NA & NA \\
\hline 3 & Sand Creek & 154,115 & 496 & 0 & -5 & -2 & 0 & -70 & 0 & -406 & -17 & -3 & -476 & NA & NA \\
\hline 4 & $\begin{array}{l}\text { Arkansas River above } \\
\text { Kaw Lake }\end{array}$ & 140,751 & 426 & 0 & -29 & -4 & 0 & -99 & 0 & -306 & -18 & -3 & -406 & NA & NA \\
\hline 5 & $\begin{array}{l}\text { Arkansas River below } \\
\text { Kaw Lake }\end{array}$ & 481,401 & 1,513 & 8 & -148 & -16 & -1 & -326 & -7 & $-1,097$ & -77 & -14 & $-1,423$ & NA & NA \\
\hline 6 & Deciduous forest & 514,177 & 1,565 & 0 & -69 & -23 & 0 & -301 & 0 & $-1,103$ & -137 & -24 & $-1,404$ & NA & NA \\
\hline 7 & Pasture & $1,140,322$ & 3,537 & 0 & -26 & -15 & 0 & -419 & 0 & $-3,072$ & -42 & -5 & $-3,491$ & NA & NA \\
\hline 8 & Central Osage & 133,793 & 513 & 0 & -2 & -2 & 0 & -71 & 0 & -429 & -11 & -2 & -501 & NA & NA \\
\hline 9 & $\begin{array}{l}\text { Hominy Creek above } \\
\text { Skiatook Lake }\end{array}$ & 242,835 & 721 & 0 & -11 & -4 & 0 & -139 & 0 & -551 & -26 & -4 & -690 & NA & NA \\
\hline 10 & Hominy Lake supply & 3,716 & 15 & 0 & 0 & 0 & 0 & -3 & 0 & -12 & 0 & 0 & -15 & NA & NA \\
\hline 11 & Burbank Oil Field & 46,574 & 143 & 0 & 0 & -1 & 0 & -17 & 0 & -124 & -2 & 0 & -140 & NA & NA \\
\hline \multirow[t]{2}{*}{12} & Naval Reserves & 22,773 & 69 & 0 & 0 & 0 & 0 & -9 & 0 & -59 & -1 & 0 & -68 & NA & NA \\
\hline & Total model area & $1,858,905$ & 5,700 & 9 & -221 & -43 & -1 & $-1,008$ & -7 & $-4,429$ & -226 & -38 & $-5,437$ & NA & NA \\
\hline \multicolumn{16}{|c|}{ Mean annual net landscape fluxes for AVG } \\
\hline 1 & Bird Creek & 212,827 & 1,381 & 0 & -15 & -7 & 0 & -245 & 0 & $-1,055$ & -71 & -11 & $-1,300$ & -109 & -38 \\
\hline 2 & Salt Creek & 178,548 & 736 & 0 & -5 & -4 & 0 & -123 & 0 & -593 & -17 & -2 & -716 & -31 & -20 \\
\hline 3 & Sand Creek & 154,115 & 664 & 0 & -5 & -2 & 0 & -112 & 0 & -522 & -26 & -4 & -633 & -53 & -33 \\
\hline 4 & $\begin{array}{l}\text { Arkansas River above } \\
\text { Kaw Lake }\end{array}$ & 140,751 & 536 & 0 & -33 & -4 & 0 & -147 & 0 & -358 & -27 & -4 & -504 & -50 & -24 \\
\hline 5 & $\begin{array}{l}\text { Arkansas River below Kaw } \\
\text { Lake }\end{array}$ & 481,401 & 2,053 & 8 & -146 & -17 & 0 & -495 & -6 & $-1,426$ & -113 & -20 & $-1,921$ & -47 & -35 \\
\hline 6 & Deciduous forest & 514,177 & 2,111 & 0 & -77 & -24 & 0 & -404 & 0 & $-1,489$ & -184 & -34 & $-1,893$ & -34 & -35 \\
\hline
\end{tabular}


Table 15. Summary of the simulated mean annual dry, average, and wet forecasts for the active model area and for each supergroup landscape water budget component and fluxes and percentage change from dry forecast for the Osage Nation Integrated Hydrologic Model._Continued

[Negative fluxes indicate the removal of water from the landscape; positive fluxes indicate an addition of water to the landscape; DRY, dry forecast; \%, percent; NA, not applicable; AVG, average forecast; WET, wet forecast]

\begin{tabular}{|c|c|c|c|c|c|c|c|c|c|c|c|c|c|c|c|}
\hline $\begin{array}{l}\text { 을 } \\
\text { 홓 } \\
\text { ڤั }\end{array}$ & Supergroup name & 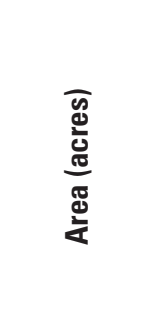 & 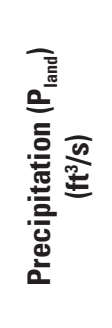 & 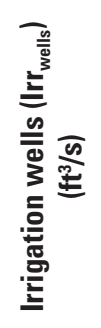 & 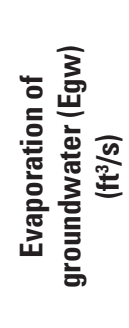 & 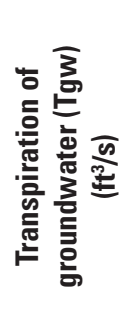 & 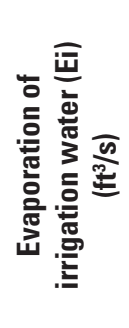 & 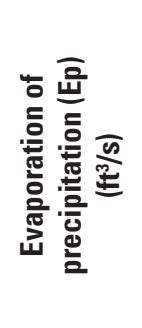 & 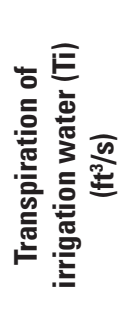 & 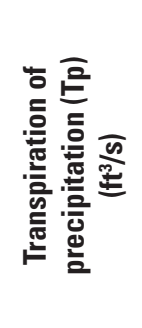 & 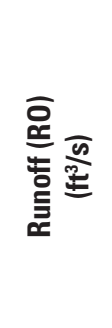 & 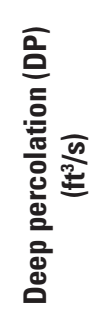 & 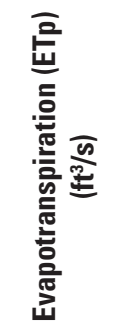 & 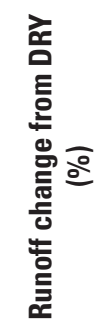 & 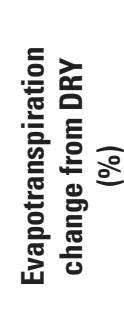 \\
\hline \multicolumn{16}{|c|}{ Mean annual net landscape fluxes for AVG - Continued } \\
\hline 7 & Pasture & $1,140,322$ & 4,609 & 0 & -29 & -16 & 0 & -756 & 0 & $-3,738$ & -103 & -12 & $-4,494$ & -145 & -29 \\
\hline 8 & Central Osage & 133,793 & 699 & 0 & -2 & -2 & 0 & -121 & 0 & -551 & -23 & -3 & -672 & -109 & -34 \\
\hline 9 & $\begin{array}{l}\text { Hominy Creek above } \\
\text { Skiatook Lake }\end{array}$ & 242,835 & 952 & 0 & -12 & -4 & 0 & -206 & 0 & -696 & -43 & -7 & -903 & -65 & -31 \\
\hline 10 & Hominy Lake supply & 3,716 & 20 & 0 & 0 & 0 & 0 & -4 & 0 & -15 & -1 & 0 & -19 & -100 & -27 \\
\hline 11 & Burbank Oil Field & 46,574 & 178 & 0 & 0 & -1 & 0 & -29 & 0 & -145 & -3 & 0 & -174 & -50 & -24 \\
\hline \multirow[t]{2}{*}{12} & Naval Reserves & 22,773 & 92 & 0 & 0 & 0 & 0 & -16 & 0 & -74 & -2 & 0 & -90 & -100 & -32 \\
\hline & Total model area & $1,858,905$ & 7,520 & 8 & -226 & -45 & 0 & $-1,558$ & -6 & $-5,560$ & -348 & -56 & $-7,118$ & -54 & -31 \\
\hline \multicolumn{16}{|c|}{ Mean annual net landscape fluxes for WET } \\
\hline 1 & Bird Creek & 212,827 & 1,917 & 0 & -22 & -14 & 0 & -310 & 0 & $-1,149$ & -400 & -58 & $-1,459$ & $-1,078$ & -55 \\
\hline 2 & Salt Creek & 178,548 & 1,031 & 0 & -7 & -5 & 0 & -155 & 0 & -666 & -187 & -23 & -821 & $-1,337$ & -38 \\
\hline 3 & Sand Creek & 154,115 & 936 & 0 & -8 & -4 & 0 & -147 & 0 & -575 & -186 & -28 & -722 & -995 & -52 \\
\hline 4 & $\begin{array}{l}\text { Arkansas River above } \\
\text { Kaw Lake }\end{array}$ & 140,751 & 747 & 0 & -32 & -5 & 0 & -189 & 0 & -403 & -138 & -18 & -591 & -666 & -46 \\
\hline 5 & $\begin{array}{l}\text { Arkansas River below } \\
\text { Kaw Lake }\end{array}$ & 481,401 & 2,953 & 4 & -143 & -21 & 0 & -628 & -3 & $-1,636$ & -601 & -89 & $-2,264$ & -681 & -59 \\
\hline 6 & Deciduous forest & 514,177 & 3,054 & 0 & -98 & -35 & 0 & -523 & 0 & $-1,576$ & -807 & -148 & $-2,099$ & -489 & -49 \\
\hline 7 & Pasture & $1,140,322$ & 6,567 & 0 & -40 & -33 & 0 & -981 & 0 & $-4,344$ & $-1,110$ & -131 & $-5,325$ & $-2,544$ & -53 \\
\hline 8 & Central Osage & 133,793 & 991 & 0 & -5 & -4 & 0 & -153 & 0 & -616 & -195 & -27 & -770 & $-1,669$ & -54 \\
\hline 9 & $\begin{array}{l}\text { Hominy Creek above } \\
\text { Skiatook Lake }\end{array}$ & 242,835 & 1,431 & 0 & -18 & -10 & 0 & -279 & 0 & -807 & -301 & -44 & $-1,086$ & $-1,056$ & -57 \\
\hline 10 & Hominy Lake supply & 3,716 & 33 & 0 & 0 & 0 & 0 & -6.1 & 0 & -18.9 & -7 & -1 & -25 & -700 & -67 \\
\hline 11 & Burbank Oil Field & 46,574 & 250 & 0 & 0 & -1 & 0 & -37 & 0 & -161 & -47 & -6 & -198 & $-2,232$ & -41 \\
\hline \multirow[t]{2}{*}{12} & Naval Reserves & 22,773 & 132 & 0 & 0 & 0 & 0 & -20 & 0 & -86 & -23 & -3 & -106 & $-2,218$ & -56 \\
\hline & Total model area & $1,858,905$ & 10,768 & 4 & -247 & -74 & 0 & $-2,009$ & -3 & $-6,289$ & $-2,160$ & -310 & $-8,298$ & -856 & -53 \\
\hline
\end{tabular}


Table 16. Summary of the simulated mean annual dry, average, and wet forecasts for the active model area and for each supergroup landscape water budget component in percentages of precipitation for the Osage Nation Integrated Hydrologic Model.

[DRY, dry forecast; NA, not applicable; AVG, average forecast; WET, wet forecast; negative fluxes indicate the removal of water from the landscape; positive fluxes indicate an addition of water to the landscape]

\begin{tabular}{|c|c|c|c|c|c|c|c|c|c|c|c|c|c|}
\hline $\begin{array}{l}\text { Super- } \\
\text { group }\end{array}$ & Supergroup name & $\begin{array}{c}\text { Area } \\
\text { (acres) }\end{array}$ & $\begin{array}{c}\text { Precipitation } \\
\left(\mathbf{P}_{\text {land }}\right)\end{array}$ & $\begin{array}{c}\text { Irrigation } \\
\text { wells } \\
\left(\text { Irr }_{\text {wells }}\right)\end{array}$ & $\begin{array}{c}\text { Evaporation } \\
\text { from } \\
\text { groundwater } \\
(\text { Egw) }\end{array}$ & $\begin{array}{l}\text { Transpiration } \\
\text { from } \\
\text { groundwater } \\
\text { (Tgw) }\end{array}$ & $\begin{array}{l}\text { Evaporation } \\
\text { from } \\
\text { irrigation } \\
\text { water } \\
\text { (Ei) }\end{array}$ & $\begin{array}{l}\text { Evaporation } \\
\text { from } \\
\text { precipitation } \\
\text { (Ep) }\end{array}$ & $\begin{array}{l}\text { Transpiration } \\
\text { from } \\
\text { irrigation } \\
\text { water } \\
\text { (Ti) }\end{array}$ & $\begin{array}{l}\text { Transpiration } \\
\text { from } \\
\text { precipitation } \\
\text { (Tp) }\end{array}$ & $\begin{array}{c}\text { Runoff } \\
\text { (RO) }\end{array}$ & $\begin{array}{c}\text { Deep } \\
\text { percolation } \\
\text { (DP) }\end{array}$ & $\begin{array}{c}\text { Evapotranspiration } \\
\text { (ETp) }\end{array}$ \\
\hline \multicolumn{14}{|c|}{ Percentage of precipitation for DRY } \\
\hline 1 & Bird Creek & 212,827 & 100.0 & 0.0 & NA & NA & 0.0 & 15.1 & 0.0 & 80.9 & 3.5 & 0.6 & 95.9 \\
\hline 2 & Salt Creek & 178,548 & 100.0 & 0.0 & NA & NA & 0.0 & 11.8 & 0.0 & 85.7 & 2.1 & 0.3 & 97.5 \\
\hline 3 & Sand Creek & 154,115 & 100.0 & 0.0 & NA & NA & 0.0 & 14.1 & 0.0 & 81.9 & 3.4 & 0.6 & 96.0 \\
\hline 4 & $\begin{array}{l}\text { Arkansas River above } \\
\text { Kaw Lake }\end{array}$ & 140,751 & 100.0 & 0.0 & NA & NA & 0.0 & 23.2 & 0.0 & 71.8 & 4.2 & 0.7 & 95.3 \\
\hline 5 & $\begin{array}{l}\text { Arkansas River below } \\
\text { Kaw Lake }\end{array}$ & 481,401 & 100.0 & 0.5 & NA & NA & 0.1 & 21.5 & 0.5 & 72.5 & 5.1 & 0.9 & 94.1 \\
\hline 6 & Deciduous forest & 514,177 & 100.0 & 0.0 & NA & NA & 0.0 & 19.2 & 0.0 & 70.5 & 8.8 & 1.5 & 89.7 \\
\hline 7 & Pasture & $1,140,322$ & 100.0 & 0.0 & NA & NA & 0.0 & 11.8 & 0.0 & 86.9 & 1.2 & 0.1 & 98.7 \\
\hline 8 & Central Osage & 133,793 & 100.0 & 0.0 & NA & NA & 0.0 & 13.8 & 0.0 & 83.6 & 2.1 & 0.4 & 97.7 \\
\hline 9 & $\begin{array}{l}\text { Hominy Creek above } \\
\text { Skiatook Lake }\end{array}$ & 242,835 & 100.0 & 0.0 & NA & NA & 0.0 & 19.3 & 0.0 & 76.4 & 3.6 & 0.6 & 95.7 \\
\hline 10 & Hominy Lake supply & 3,716 & 100.0 & 0.0 & NA & NA & 0.0 & 20.0 & 0.0 & 80.0 & 0.0 & 0.0 & 100.0 \\
\hline 11 & Burbank Oil Field & 46,574 & 100.0 & 0.0 & NA & NA & 0.0 & 11.9 & 0.0 & 86.7 & 1.4 & 0.0 & 97.9 \\
\hline \multirow[t]{2}{*}{12} & Naval Reserves & 22,773 & 100.0 & 0.0 & NA & NA & 0.0 & 13.0 & 0.0 & 85.5 & 1.4 & 0.0 & 98.6 \\
\hline & Total model area & $1,858,905$ & 100.0 & 0.2 & NA & NA & 0.0 & 17.7 & 0.1 & 77.7 & 4.0 & 0.7 & 95.4 \\
\hline \multicolumn{14}{|c|}{ Percentage of precipitation for AVG } \\
\hline 1 & Bird Creek & 212,827 & 100.0 & 0.0 & NA & NA & 0.0 & 17.7 & 0.0 & 76.4 & 5.1 & 0.8 & 94.1 \\
\hline 2 & Salt Creek & 178,548 & 100.0 & 0.0 & NA & NA & 0.0 & 16.7 & 0.0 & 80.6 & 2.4 & 0.3 & 97.3 \\
\hline 3 & Sand Creek & 154,115 & 100.0 & 0.0 & NA & NA & 0.0 & 16.9 & 0.0 & 78.6 & 3.9 & 0.6 & 95.5 \\
\hline 4 & $\begin{array}{l}\text { Arkansas River above } \\
\text { Kaw Lake }\end{array}$ & 140,751 & 100.0 & 0.0 & NA & NA & 0.0 & 27.4 & 0.0 & 66.8 & 5.1 & 0.8 & 94.1 \\
\hline 5 & $\begin{array}{l}\text { Arkansas River below } \\
\text { Kaw Lake }\end{array}$ & 481,401 & 100.0 & 0.4 & NA & NA & 0.0 & 24.1 & 0.3 & 69.5 & 5.5 & 1.0 & 93.6 \\
\hline 6 & Deciduous forest & 514,177 & 100.0 & 0.0 & NA & NA & 0.0 & 19.1 & 0.0 & 70.5 & 8.7 & 1.6 & 89.7 \\
\hline 7 & Pasture & $1,140,322$ & 100.0 & 0.0 & NA & NA & 0.0 & 16.4 & 0.0 & 81.1 & 2.2 & 0.3 & 97.5 \\
\hline 8 & Central Osage & 133,793 & 100.0 & 0.0 & NA & NA & 0.0 & 17.3 & 0.0 & 78.9 & 3.3 & 0.5 & 96.2 \\
\hline 9 & $\begin{array}{l}\text { Hominy Creek above } \\
\text { Skiatook Lake }\end{array}$ & 242,835 & 100.0 & 0.0 & NA & NA & 0.0 & 21.7 & 0.0 & 73.1 & 4.5 & 0.7 & 94.8 \\
\hline
\end{tabular}


Table 16. Summary of the simulated mean annual dry, average, and wet forecasts for the active model area and for each supergroup landscape water budget component in percentages of precipitation for the Osage Nation Integrated Hydrologic Model.-Continued

[DRY, dry forecast; NA, no data; AVG, average forecast; WET, wet forecast]

\begin{tabular}{|c|c|c|c|c|c|c|c|c|c|c|c|c|c|}
\hline $\begin{array}{l}\text { Super- } \\
\text { group }\end{array}$ & Supergroup name & $\begin{array}{c}\text { Area } \\
\text { (acres) }\end{array}$ & $\begin{array}{c}\text { Precipitation } \\
\left(\mathbf{P}_{\text {land }}\right)\end{array}$ & $\begin{array}{c}\text { Irrigation } \\
\text { wells } \\
\left(\operatorname{Irr}_{\text {wells }}\right)\end{array}$ & $\begin{array}{l}\text { Evaporation } \\
\text { from } \\
\text { groundwater } \\
(\mathrm{Egw})\end{array}$ & $\begin{array}{l}\text { Transpiration } \\
\text { from } \\
\text { groundwater } \\
(\mathrm{Tgw})\end{array}$ & $\begin{array}{l}\text { Evaporation } \\
\text { from } \\
\text { irrigation } \\
\text { water } \\
\text { (Ei) }\end{array}$ & $\begin{array}{l}\text { Evaporation } \\
\text { from } \\
\text { precipitation } \\
\text { (Ep) }\end{array}$ & $\begin{array}{l}\text { Transpiration } \\
\text { from } \\
\text { irrigation } \\
\text { water } \\
\text { (Ti) }\end{array}$ & $\begin{array}{l}\text { Transpiration } \\
\text { from } \\
\text { precipitation } \\
\text { (Tp) }\end{array}$ & $\begin{array}{c}\text { Runoff } \\
\text { (RO) }\end{array}$ & $\begin{array}{c}\text { Deep } \\
\text { percolation } \\
\text { (DP) }\end{array}$ & $\begin{array}{l}\text { Evapotranspiration } \\
\text { (ETp) }\end{array}$ \\
\hline \multicolumn{14}{|c|}{ Percentage of precipitation for AVG_-Continued } \\
\hline 10 & Hominy Lake supply & 3,716 & 100.0 & 0.0 & NA & NA & 0.0 & 20.9 & 0.0 & 75.2 & 3.4 & 0.5 & 96.1 \\
\hline 11 & Burbank Oil Field & 46,574 & 100.0 & 0.0 & NA & NA & 0.0 & 16.4 & 0.0 & 81.4 & 1.9 & 0.3 & 97.8 \\
\hline \multirow[t]{2}{*}{12} & Naval Reserves & 22,773 & 100.0 & 0.0 & NA & NA & 0.0 & 17.3 & 0.0 & 80.7 & 1.8 & 0.2 & 98.0 \\
\hline & Total model area & $1,858,905$ & 100.0 & 0.1 & NA & NA & 0.0 & 20.7 & 0.1 & 73.9 & 4.6 & 0.7 & 94.6 \\
\hline \multicolumn{14}{|c|}{ Percentage of precipitation for WET } \\
\hline 1 & Bird Creek & 212,827 & 100.0 & 0.0 & NA & NA & 0.0 & 16.2 & 0.0 & 59.9 & 20.9 & 3.0 & 76.1 \\
\hline 2 & Salt Creek & 178,548 & 100.0 & 0.0 & NA & NA & 0.0 & 15.0 & 0.0 & 64.6 & 18.1 & 2.3 & 79.6 \\
\hline 3 & Sand Creek & 154,115 & 100.0 & 0.0 & NA & NA & 0.0 & 15.7 & 0.0 & 61.4 & 19.9 & 3.0 & 77.1 \\
\hline 4 & $\begin{array}{l}\text { Arkansas River above } \\
\text { Kaw Lake }\end{array}$ & 140,751 & 100.0 & 0.0 & NA & NA & 0.0 & 25.2 & 0.0 & 53.9 & 18.5 & 2.4 & 79.2 \\
\hline 5 & $\begin{array}{l}\text { Arkansas River below } \\
\text { Kaw Lake }\end{array}$ & 481,401 & 100.0 & 0.1 & NA & NA & 0.0 & 21.3 & 0.1 & 55.4 & 20.4 & 3.0 & 76.6 \\
\hline 6 & Deciduous forest & 514,177 & 100.0 & 0.0 & NA & NA & 0.0 & 17.1 & 0.0 & 51.6 & 26.4 & 4.8 & 68.7 \\
\hline 7 & Pasture & $1,140,322$ & 100.0 & 0.0 & NA & NA & 0.0 & 14.9 & 0.0 & 66.2 & 16.9 & 2.0 & 81.1 \\
\hline 8 & Central Osage & 133,793 & 100.0 & 0.0 & NA & NA & 0.0 & 15.5 & 0.0 & 62.2 & 19.6 & 2.7 & 77.7 \\
\hline 9 & $\begin{array}{l}\text { Hominy Creek above } \\
\text { Skiatook Lake }\end{array}$ & 242,835 & 100.0 & 0.0 & NA & NA & 0.0 & 19.5 & 0.0 & 56.4 & 21.0 & 3.1 & 75.9 \\
\hline 10 & Hominy Lake supply & 3,716 & 100.0 & 0.0 & NA & NA & 0.0 & 18.5 & 0.0 & 57.4 & 21.2 & 2.9 & 75.9 \\
\hline 11 & Burbank Oil Field & 46,574 & 100.0 & 0.0 & NA & NA & 0.0 & 14.7 & 0.0 & 64.4 & 18.7 & 2.3 & 79.0 \\
\hline \multirow[t]{2}{*}{12} & Naval Reserves & 22,773 & 100.0 & 0.0 & NA & NA & 0.0 & 15.2 & 0.0 & 65.0 & 17.6 & 2.2 & 80.2 \\
\hline & Total model area & $1,858,905$ & 100.0 & 0.0 & NA & NA & 0.0 & 18.7 & 0.0 & 58.4 & 20.1 & 2.9 & 77.1 \\
\hline
\end{tabular}




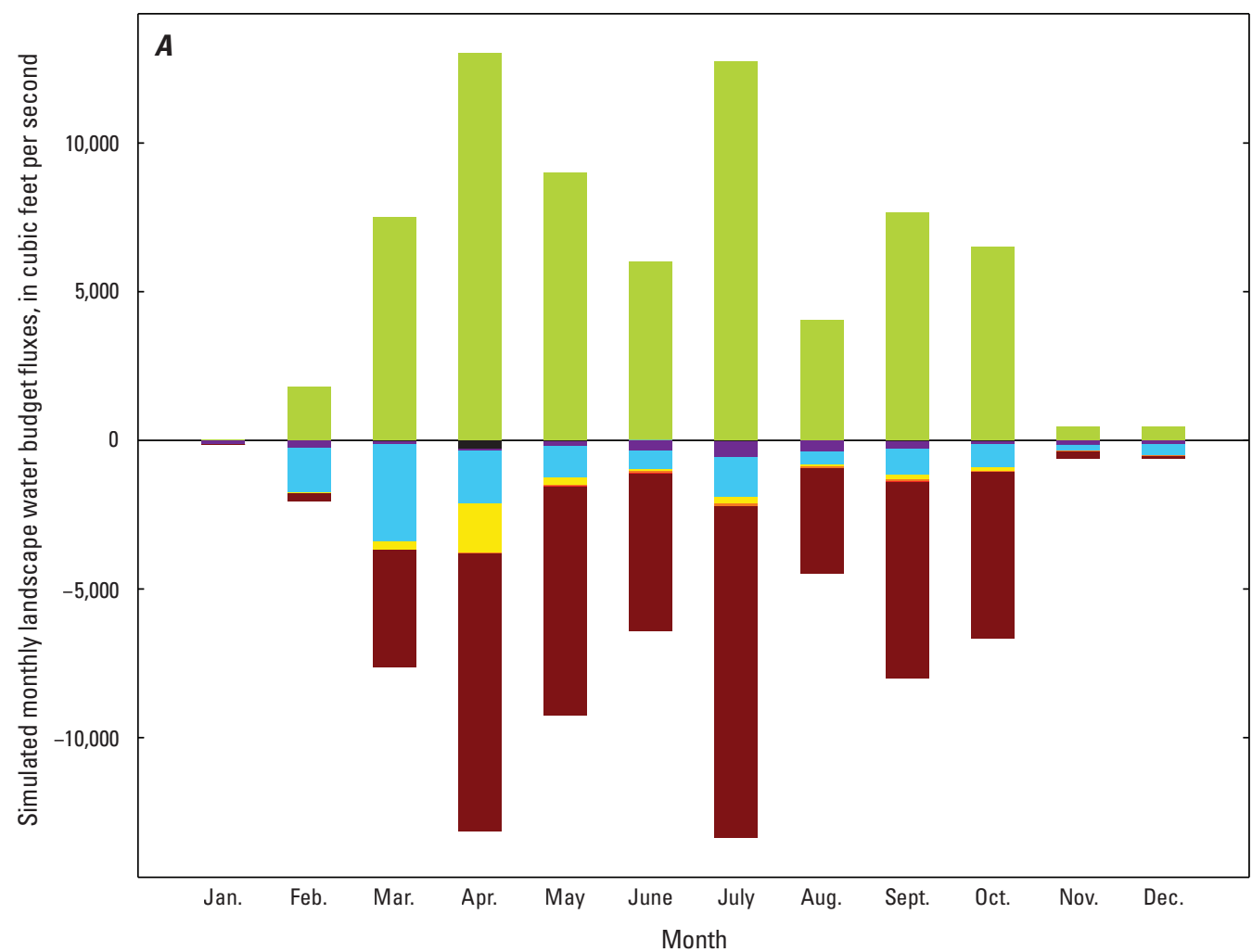

EXPLANATION

Deep percolation (DP)

Evaporation of groundwater (Egw)

Evaporation of irrigation water (Ei)

Evaporation of precipitation (Ep)

Irrigation wells (Irr wells $)$

Precipitation $\left(\mathbf{P}_{\text {land }}\right)$

Runoff (RO)

Transpiration of groundwater (Tgw)

Transpiration of irrigation water (Ti)

Transpiration of precipitation (Tp)

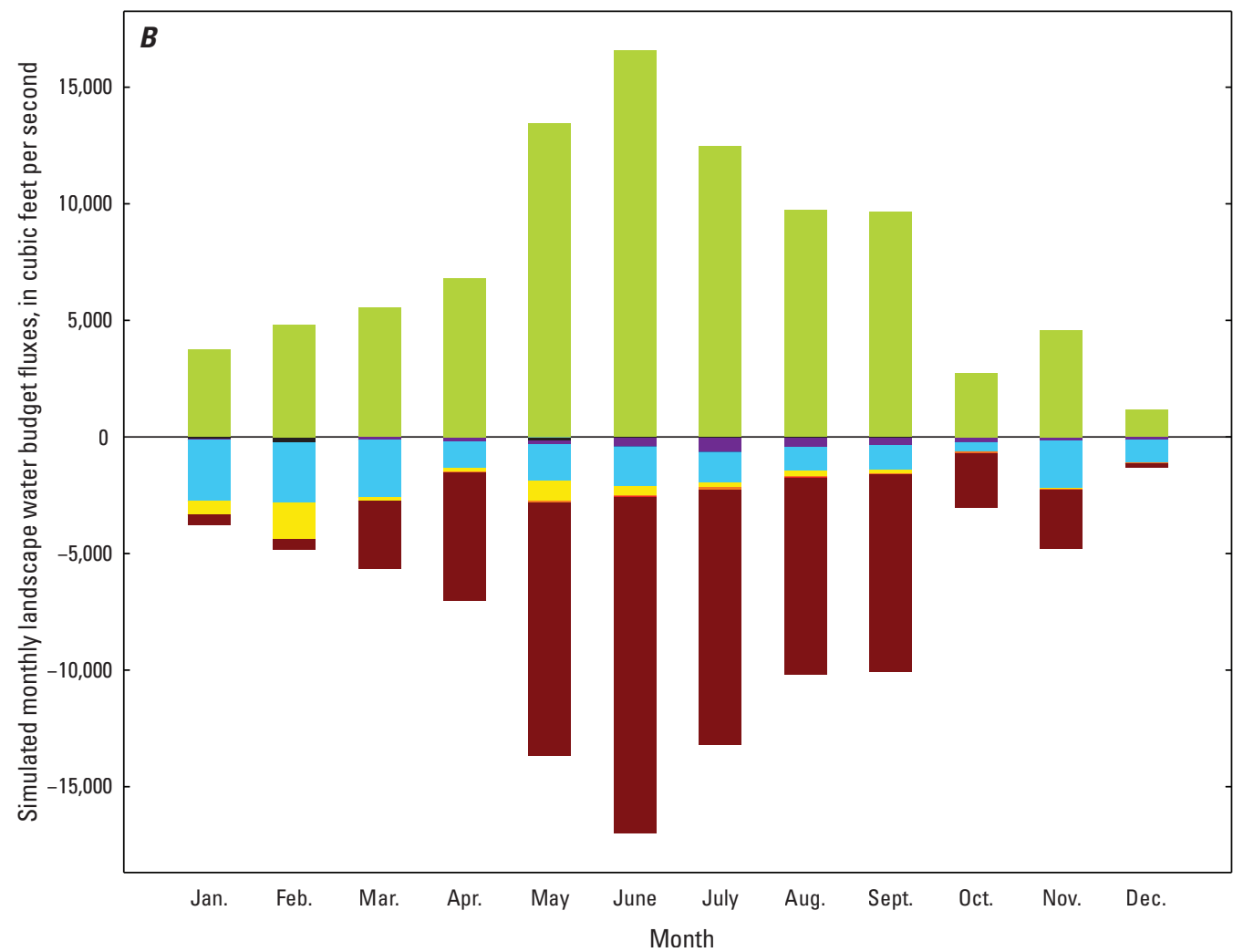

EXPLANATION

eep percolation (DP)

Evaporation of groundwater (Egw)

Evaporation of irrigation water (Ei)

Evaporation of precipitation (Ep)

Irrigation wells ( (rr $_{\text {wells }}$ )

Precipitation $\left(\mathbf{P}_{\text {land }}\right)$

Runoff (RO)

Transpiration of groundwater (Tgw)

Transpiration of irrigation water (Ti)

Transpiration of precipitation (Tp)

Figure 27. Simulated mean monthly net landscape water budget fluxes for the Osage Nation Integrated Hydrologic Model. $A$, dry forecast; $B$, average forecast; and $C$, wet forecast. 


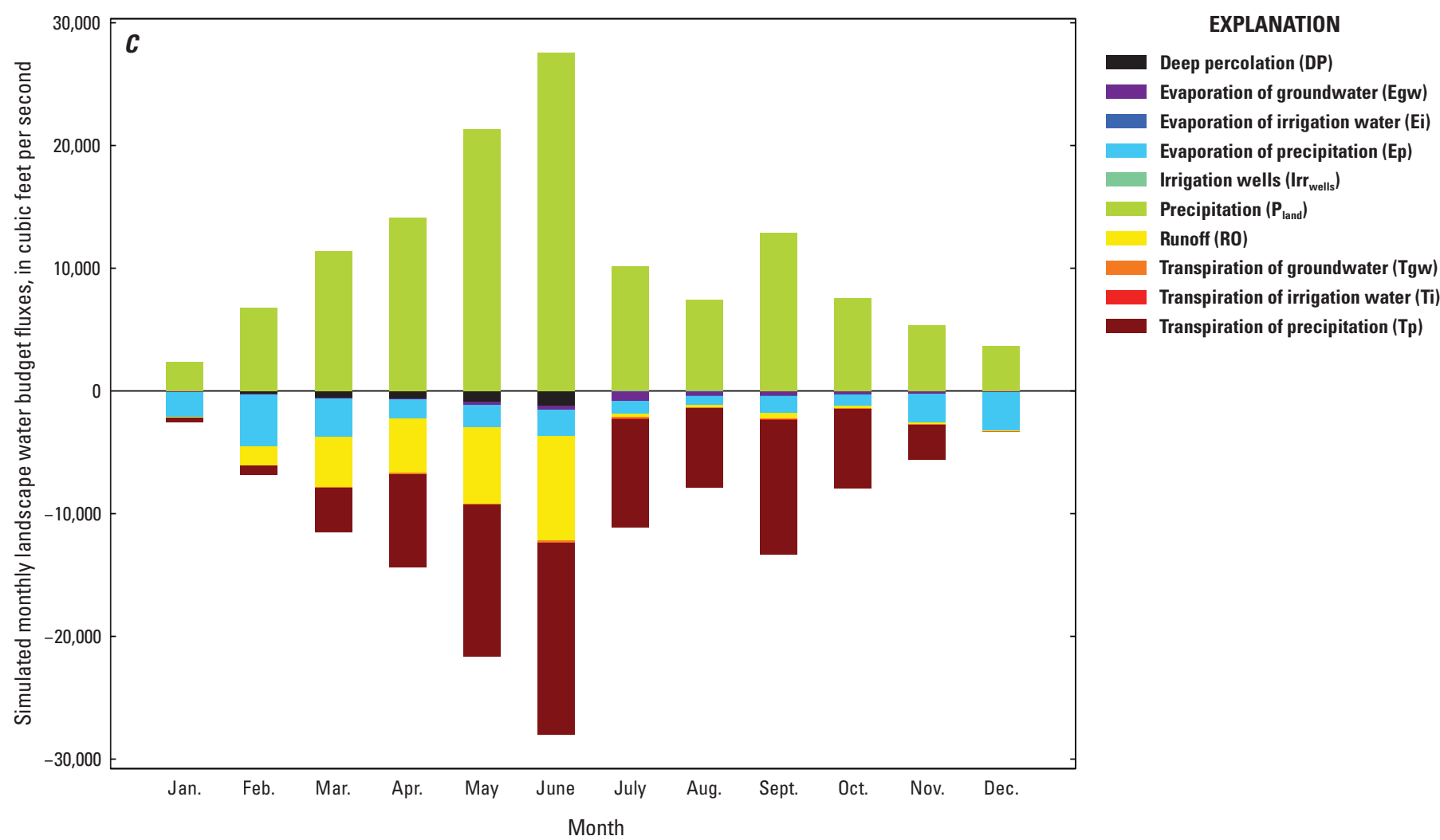

Figure 27. Simulated mean monthly net landscape water budget fluxes for the Osage Nation Integrated Hydrologic Model. $A$, dry forecast; $B$, average forecast; and $C$, wet forecast.-Continued

Mean annual fluxes for net production and irrigation wells were net outflows for all forecasts but were not substantial fluxes when compared to the other groundwater-flow budget components. Irrigation wells followed the expected trend of highest mean annual outflows of $8.7 \mathrm{ft}^{3} / \mathrm{s}$ for the DRY forecast and lowest mean annual outflows of $4.1 \mathrm{ft}^{3} / \mathrm{s}$ for the WET forecast. Irrigation wells supply groundwater to crops that did not receive enough water from precipitation or root uptake to meet crop needs; therefore, the highest withdrawals during the DRY forecast and lowest withdrawals during the WET forecast corresponded to standard irrigation practices. Production wells demonstrated mean annual outflows of 11.2, 9.7, and $9.8 \mathrm{ft}^{3} / \mathrm{s}$ for the DRY, AVG, and WET forecasts, respectively (table 17). Increased fluxes of production wells for the DRY forecast are likely due to the increased demand for water use during dry periods that is typical of production systems. Fluxes for the AVG and WET forecasts were almost the same which may result from similar irrigation requirements of lawns during average or wet conditions.

Because of the theoretical nature of the forecasts, where climate inputs were constant for each year of the simulations, the model results demonstrated trends that relate to the groundwater-flow system finding a new equilibrium between inflows and outflows. These trends are most noticeable in the net storage results for the first 30 years of each forecast. DRY and AVG forecast net storage rates demonstrate the most change in the first 10 years of the simulation where they begin as outflows from the groundwater-flow system and transition to inflows to the groundwater-flow system. The WET forecast storage outflows decreased mostly within the first 30 years of the simulation (2015-45), after which annual changes in outflows of storage become negligible as the groundwater-flow system approached a new equilibrium state (fig. 29). The WET forecast storage took longer to equilibrate compared to the other forecasts because higher flux rates will take more time to equilibrate given the same study area; there was a larger difference in precipitation from the AVG to the WET forecast $\left(3,243 \mathrm{ft}^{3} / \mathrm{s}\right)$ than the DRY to the AVG forecast $\left(1,820 \mathrm{ft}^{3} / \mathrm{s}\right)$ (table 15). Additionally, the increased precipitation for the WET forecast did reduce the magnitude of net farm net recharge when compared to the DRY and AVG forecasts. The transition of farm net recharge from positive to negative by 2040 indicated that the increased precipitation during the WET forecast increased recharge to the water table, but the precipitation also increased groundwater ET from plants with roots near the water table. 
Table 17. Simulated mean annual groundwater-flow budget fluxes for the active model area and by supergroup for the dry, average, and wet forecasts of the Osage Nation Integrated Hydrologic Model.

[Negative fluxes indicate a loss of water from the groundwater-flow system; positive fluxes indicate a gain of water to the groundwater-flow system; DRY, dry forecast; --, no data; AVG, average forecast; WET, wet forecast; gw, groundwater; intersupergroup gw flow, groundwater flow into (positive) or out of (negative) a supergroup]

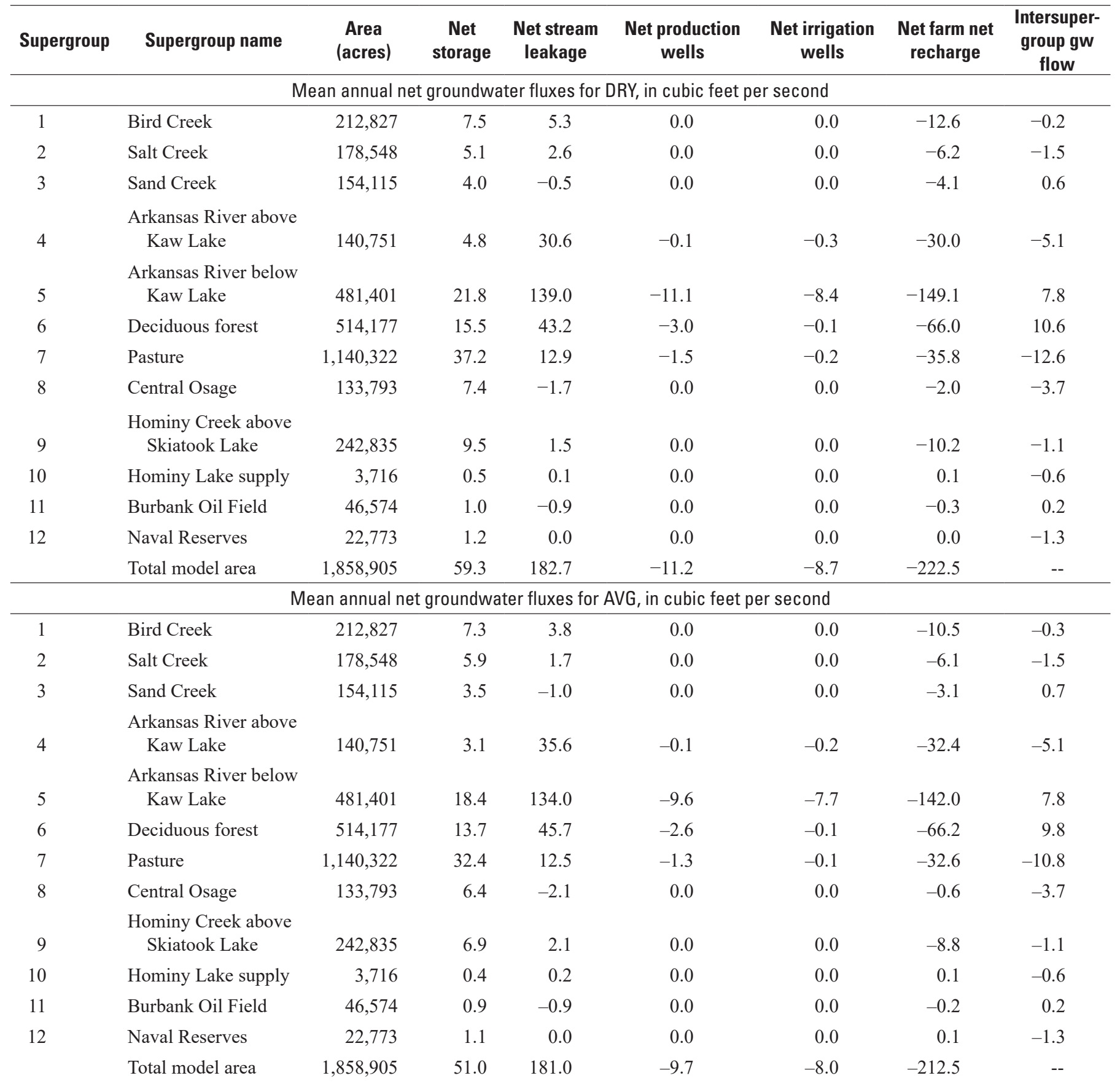


Table 17. Simulated mean annual groundwater-flow budget fluxes for the active model area and by supergroup for the dry, average, and wet forecasts of the Osage Nation Integrated Hydrologic Model._Continued

[Negative fluxes indicate a loss of water from the groundwater-flow system; positive fluxes indicate a gain of water to the groundwater-flow system; DRY, dry forecast; --, no data; AVG, average forecast; WET, wet forecast; gw, groundwater; intersupergroup gw flow, groundwater flow into (positive) or out of (negative) a supergroup]

\begin{tabular}{|c|c|c|c|c|c|c|c|c|}
\hline Supergroup & Supergroup name & $\begin{array}{c}\text { Area } \\
\text { (acres) }\end{array}$ & $\begin{array}{c}\text { Net } \\
\text { storage }\end{array}$ & $\begin{array}{l}\text { Net stream } \\
\text { leakage }\end{array}$ & $\begin{array}{l}\text { Net production } \\
\text { wells }\end{array}$ & $\begin{array}{l}\text { Net irrigation } \\
\text { wells }\end{array}$ & $\begin{array}{l}\text { Net farm net } \\
\text { recharge }\end{array}$ & $\begin{array}{l}\text { Intersuper- } \\
\text { group gw } \\
\text { flow }\end{array}$ \\
\hline \multicolumn{9}{|c|}{ Mean annual net groundwater fluxes for WET, in cubic feet per second } \\
\hline 2 & Salt Creek & 178,548 & -11.3 & 0.7 & 0.0 & 0.0 & 12.0 & -1.3 \\
\hline 3 & Sand Creek & 154,115 & -6.7 & -10.1 & 0.0 & 0.0 & 15.9 & 0.9 \\
\hline 5 & $\begin{array}{l}\text { Arkansas River below } \\
\text { Kaw Lake }\end{array}$ & 481,401 & -18.6 & 99.6 & -9.7 & -3.9 & -72.6 & 8.4 \\
\hline 6 & Deciduous forest & 514,177 & -17.8 & 11.0 & -2.7 & -0.1 & 17.2 & -6.3 \\
\hline 7 & Pasture & $1,140,322$ & -53.4 & 0.8 & -1.2 & -0.1 & 58.6 & -4.3 \\
\hline 10 & Hominy Lake supply & 3,716 & -0.3 & 0.1 & 0.0 & 0.0 & 1.0 & -0.8 \\
\hline 11 & Burbank Oil Field & 46,574 & -2.9 & -1.9 & 0.0 & 0.0 & 4.5 & 0.3 \\
\hline \multirow[t]{2}{*}{12} & Naval Reserves & 22,773 & -1.3 & 0.0 & 0.0 & 0.0 & 2.6 & -1.3 \\
\hline & Total model area & $1,858,905$ & -78.3 & 103.1 & -9.8 & -4.1 & -5.7 & -- \\
\hline
\end{tabular}




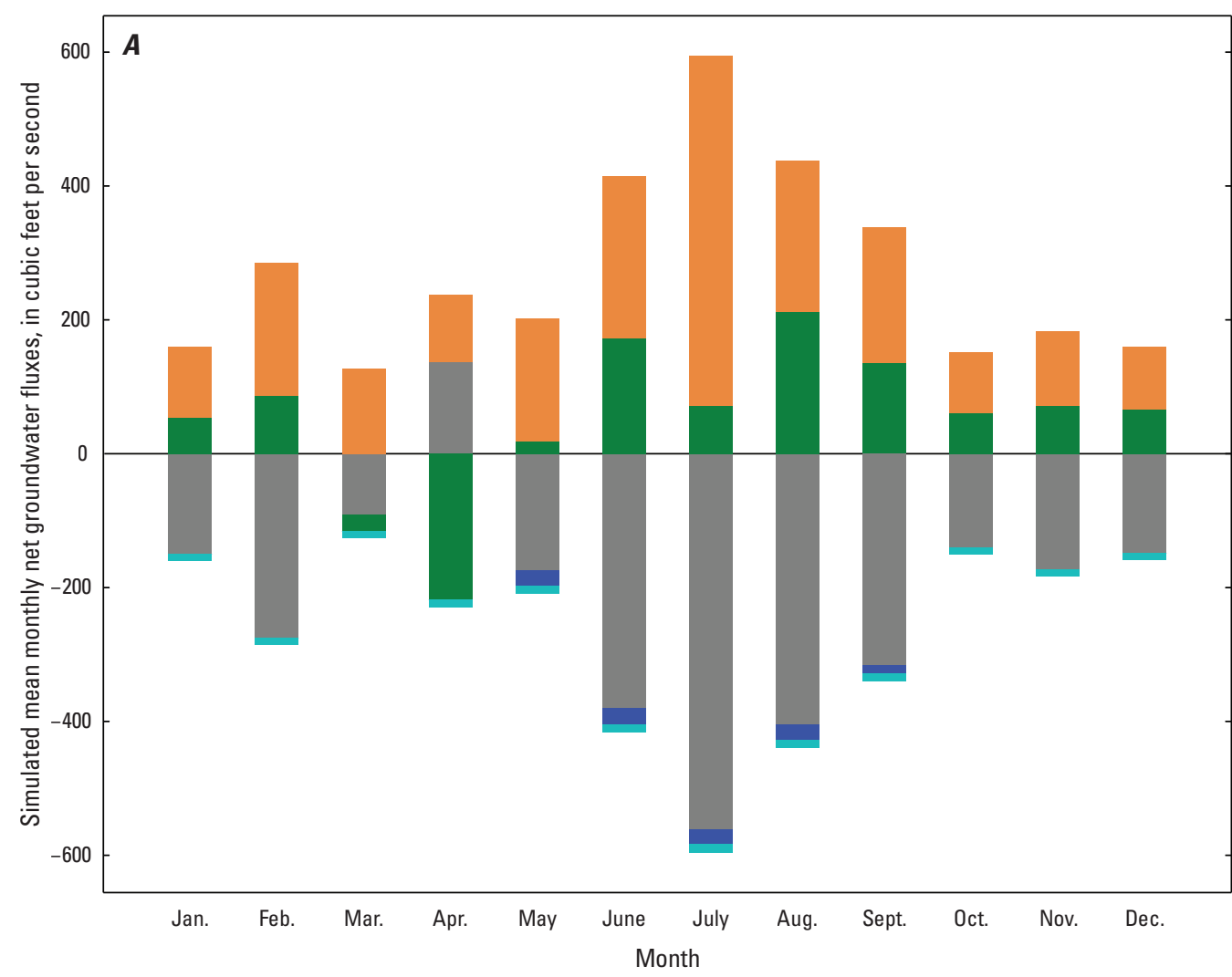

EXPLANATION

Net farm net recharge

Net storage

Net irrigation wells

Net production wells

Net stream leakage

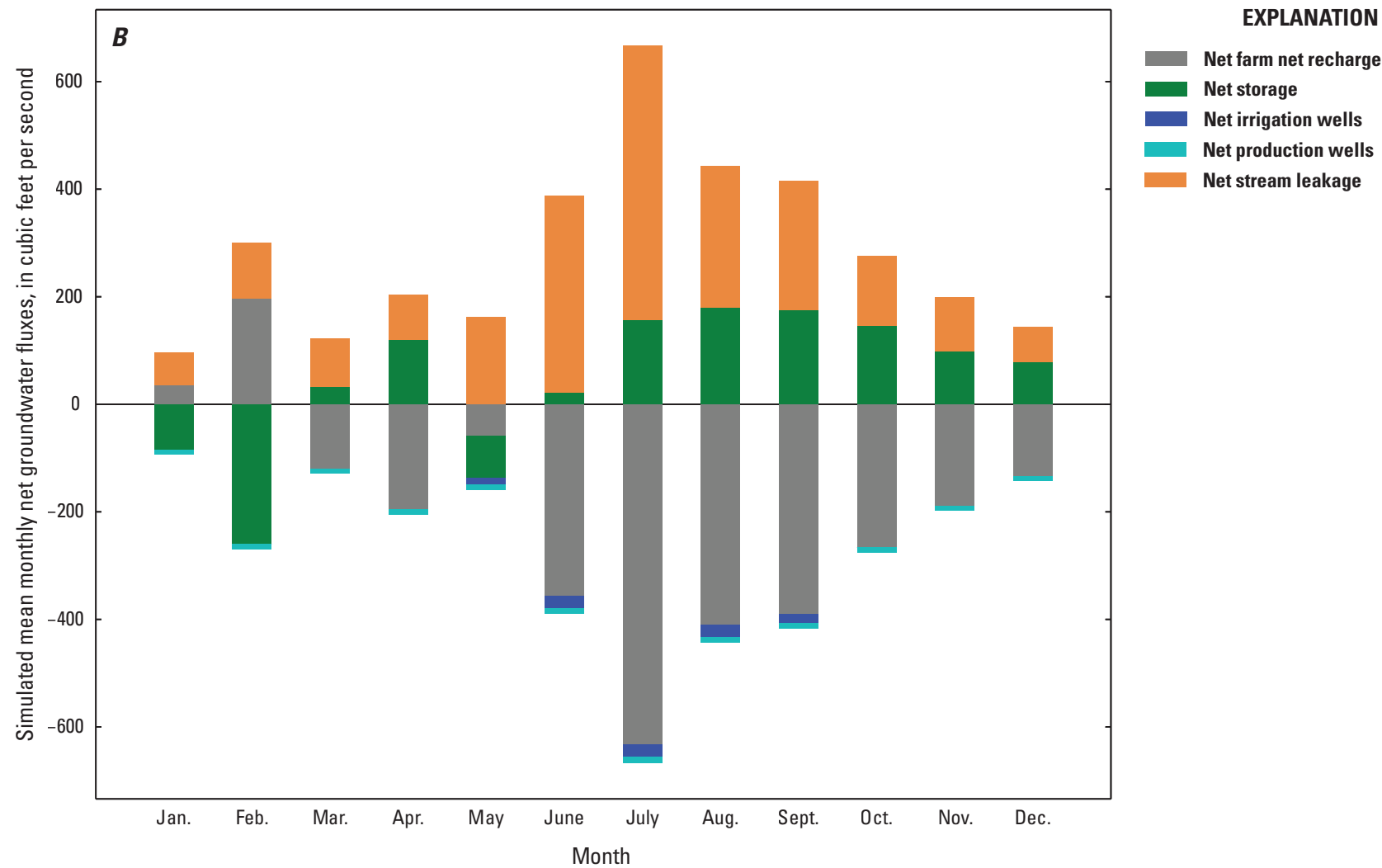

Figure 28. Simulated mean monthly groundwater-flow budget fluxes for the Osage Nation Integrated Hydrologic Model. $A$, dry forecast; $B$, average forecast; and $C$, wet forecast. 


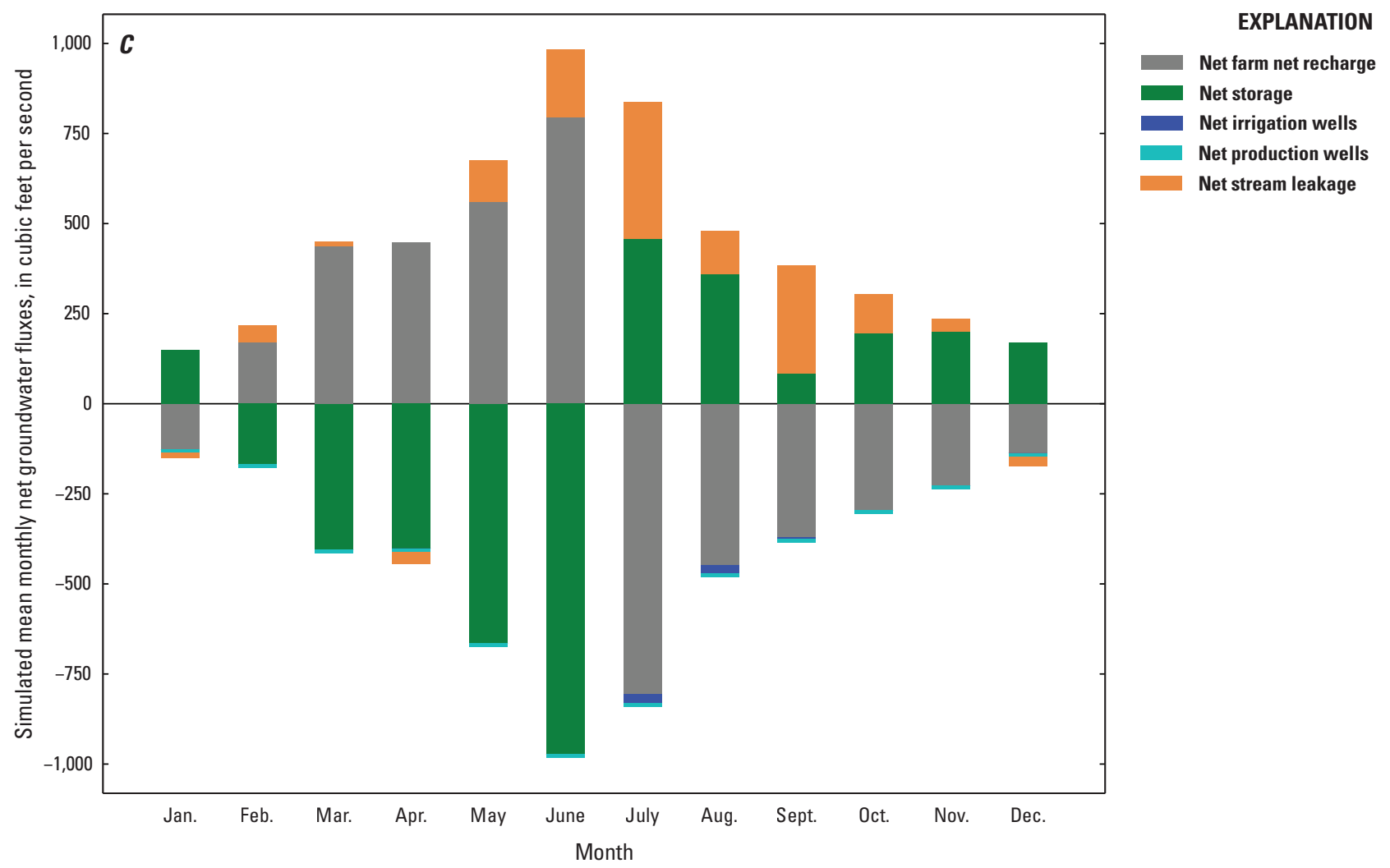

Figure 28. Simulated mean monthly groundwater-flow budget fluxes for the Osage Nation Integrated Hydrologic Model. $A$, dry forecast; $B$, average forecast; and $C$, wet forecast.-Continued

\section{Supergroup Landscape and Groundwater-Flow Budgets}

Landscape and groundwater-flow budgets for each forecast were created for each of the 12 supergroups in the ONIHM (fig. 8). Magnitudes of each landscape and groundwater-flow budget component varied across supergroups and by forecast; however, most supergroup landscape water budgets resembled those of the model area, plus many similarities in trends persisted among several supergroups. The similar landscape water budgets and trends for each forecast demonstrated that the landscape part of the hydrologic system responded similarly during persistent dry, average, and wet conditions that were simulated with each forecast. The primary landscape and groundwater-flow budget differences occurred for the WET forecast when there was excess water available to the hydrologic system.

The annual landscape water budgets for all 12 supergroups were similar for each forecast, although in general, fluxes were lowest for the DRY forecast and highest for the WET forecast. $\mathrm{P}_{\text {land }}$ and Tp were the predominant inflow and outflow components for all supergroups and forecasts, respectively (tables 15 and 16). The sum of Ep and Tp, total ET from precipitation (ETp), was the dominant outflow from the landscape in all supergroups and forecasts. DRY forecast ETp consumed an average of 95.4 percent of precipitation for all supergroups; the Naval Reserves supergroup had the highest percentage of ETp at 100 percent, and the Deciduous forest supergroup had the lowest percentage at 89.7 percent. Land use was an important factor in the forecast landscape water budgets and affected ETp such that generally the supergroups with the highest amount of pasture (Pasture, Burbank Oil Field, and Naval Reserves) also had the highest percentage of ETp and, conversely, the supergroups with more deciduous forest (Deciduous forest, Bird Creek, and Sand Creek) had less ETp. Further, the regions with more pasture and ETp had lower percentages of runoff and deep percolation than regions with more forest. WET forecast ETp constituted about 77 percent of precipitation. ETp fluxes increased less from DRY $\left(5,437 \mathrm{ft}^{3} / \mathrm{s}\right)$ to AVG $\left(7,118 \mathrm{ft}^{3} / \mathrm{s}\right)$ than from DRY to WET $\left(8,298 \mathrm{ft}^{3} / \mathrm{s}\right)$ forecasts for each supergroup (table 15), which indicated that land use was consuming near its maximum amount of precipitation for the WET forecast. Further, RO and DP were similar or the same for the DRY and AVG forecasts but increased by three to five times for the WET forecast (table 15). The large increase in both RO and DP for the WET forecast indicated that ET requirements were nearly met. 


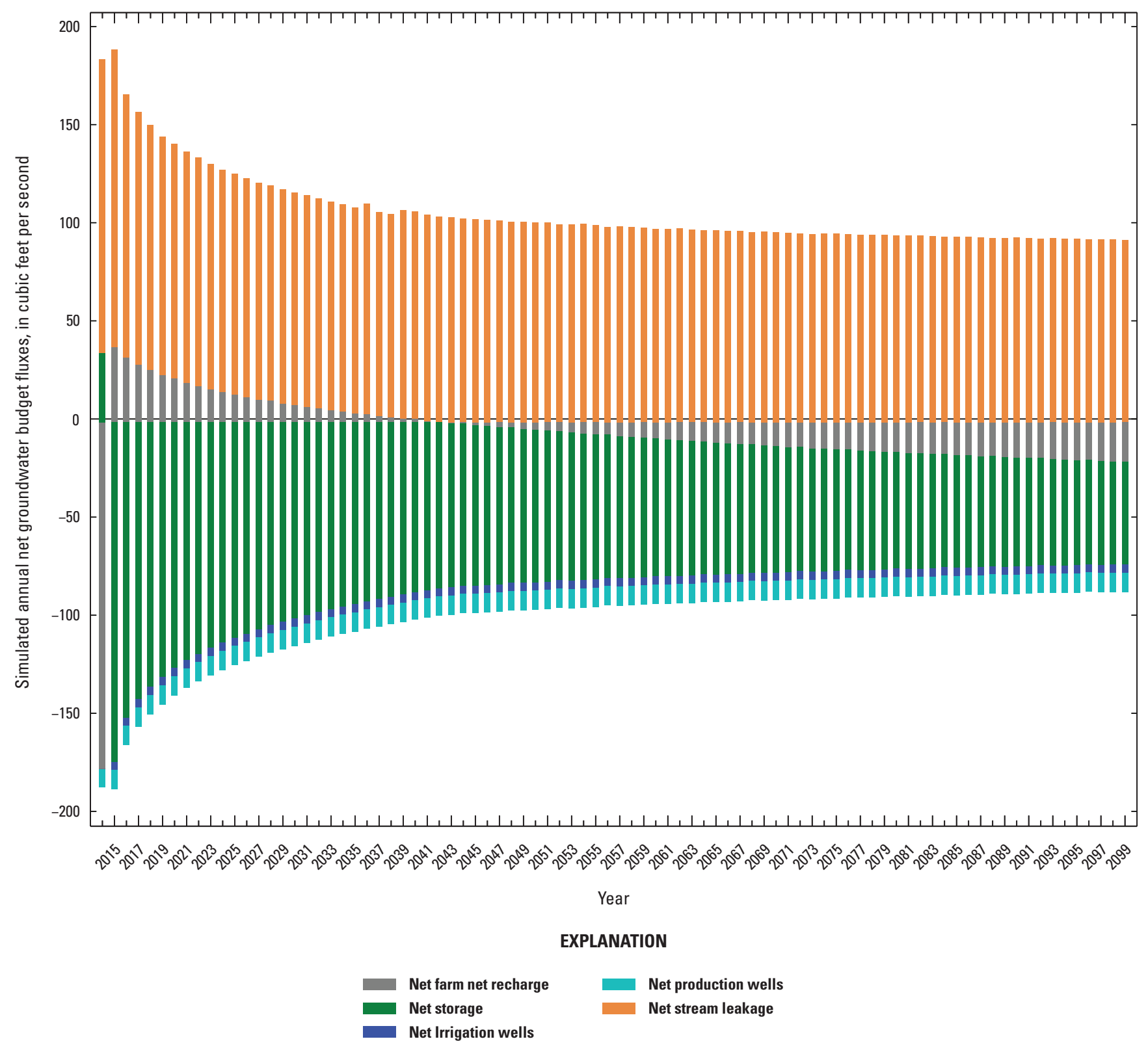

Figure 29. Simulated mean annual groundwater-flow budget fluxes for the wet forecast of the Osage Nation Integrated Hydrologic Model. 
Individual supergroup runoff fluxes for the AVG forecast $\left(348 \mathrm{ft}^{3} / \mathrm{s}\right)$ were greater than fluxes for the DRY $\left(226 \mathrm{ft}^{3} / \mathrm{s}\right)$ forecast. The DRY and AVG forecast RO fluxes were minimal for all supergroups, and RO averaged 4.0 and 4.6 percent of precipitation, respectively (table 16). As described above, the supergroups with a larger percentage of deciduous forest land-use (Deciduous forest and Arkansas River below Kaw Lake) tended to have the highest percentage of precipitation that went to runoff because the deciduous forest consumed less water than the pasture and subsequently left more water available to run off the landscape. Forested land also was concentrated along steep terrain in the study area that typically promotes runoff because of the increased slope, but as discussed in the "Integrated Hydrologic-Flow Model Construction and Discretization" section of this report, MF-OWHM calculates consumption of precipitation via ET before calculating runoff and recharge; therefore, in the ONIHM, the increased runoff for the Deciduous forest supergroup compared to the pasture supergroup is due to the difference in consumption of pasture and forest. RO was a more substantial outflow component of the landscape water budget for all supergroups in the WET forecast $\left(20.1 \mathrm{ft}^{3} / \mathrm{s}\right)$ - runoff increased about 54 percent between the DRY and AVG forecasts and increased 856 percent between the DRY and WET forecasts.

Deep percolation fluxes varied between supergroups for each forecast, but overall fluxes were between 0 and 5 percent of precipitation. Average annual DP was zero for three supergroups (Hominy Lake supply, Burbank Oil Field, and Naval Reserves) during the DRY and AVG forecasts. The Deciduous forest supergroup demonstrated the highest fluxes and percentage of deep percolation relative to precipitation for all forecasts (tables 15 and 16).

Annual groundwater fluxes varied for each forecast and supergroup. Groundwater fluxes were several orders of magnitude less than many landscape fluxes. Like the landscape water budgets, groundwater-flow budget components followed the same trends for the DRY and AVG forecasts across most supergroups. DRY and AVG forecast groundwater-flow budgets were characterized by inflows to the groundwaterflow system from storage and stream leakage and outflows from the groundwater-flow system to farm net recharge. Only three supergroups (Sand Creek, Central Osage, and Burbank Oil Field) demonstrated outflows from the groundwater-flow system to stream leakage for the DRY and AVG forecasts (table 17) that demonstrated "gaining" conditions. Like the landscape water budgets, changes in fluxes were small between the DRY and AVG forecast fluxes and flux changes were much greater from the AVG to WET forecast. A total of four supergroups had outflows to the groundwater-flow system from production and irrigation wells for each forecast.
Farm net recharge was an outflow from the groundwater-flow system for the DRY and AVG forecasts in 10 supergroups and an inflow for the WET forecast in 10 supergroups. The shift in farm net recharge from outflows to inflows for the WET forecast is due to the increased deep percolation from the landscape, which resulted in deep percolation that was greater than groundwater ET.

The groundwater-flow budgets from the ONIHM forecasts indicate that the groundwater-flow system behavior during the DRY and AVG forecasts is similar to the 1950-2014 period groundwater-flow system. The WET forecast results indicated that the groundwater-flow system responded more to a wetter climate than a drier climate. During dry years, the system's decreases in storage and stream leakage are less than the increases in those components during wet periods.

Simulated water-table maps were created from the final stress period (December 31, 2099) groundwater levels for each forecast (fig. 14). Groundwater-flow directions for each forecast were consistent with the groundwater-flow directions at the end of the 1950-2014 period. The water table was similar for the DRY and AVG forecasts for most of the study area. WET forecast groundwater-level contours migrated eastward because groundwater levels were higher than the DRY and AVG forecasts. Supergroups in the eastern and central regions, such as Bird Creek, Sand Creek, and Hominy Creek above Skiatook Lake, experienced the largest spatial changes in the water table (fig. 14). In contrast, the Arkansas River supergroups demonstrated more stable water tables for each forecast.

\section{Forecasted Fresh/Marginal Groundwater and Saline Groundwater}

The fresh/marginal groundwater interface map created for this study was compared to the water table for the final stress period (December 2099) of each forecast. The saturated thickness of fresh/marginal groundwater was calculated as the difference between the water-table altitude and the altitude of the fresh/marginal groundwater map. Average saturated thickness of fresh/marginal groundwater for DRY, AVG, and WET forecasts was 124.7, 126.1, and $144.4 \mathrm{ft}$, respectively (table 18). The spatial distribution of fresh/marginal groundwater did not vary substantially for each forecast (fig. $30 A-C$ ). The thickest regions of fresh/marginal groundwater were the same as regions for the calibration model and included the eastern part of the study area along Sand Creek, Bird Creek, and Hominy Creek and the Arkansas River region below the Ralston, Okla., streamgage (USGS station 07152500). 
Table 18. Summary of simulated saturated thickness of the fresh/marginal and saline groundwater for each forecast by supergroup of the Osage Nation Integrated Hydrologic Model.

[ft, foot thickness, in percent, percentage of total saturated thickness that is fresh/marginal groundwater calculated as follows: average thickness of fresh/ marginal groundwater divided by (average thickness of fresh/marginal groundwater + average thickness of saline groundwater) multiplied by 100; DRY, dry forecast; AVG, average forecast; WET, wet forecast]

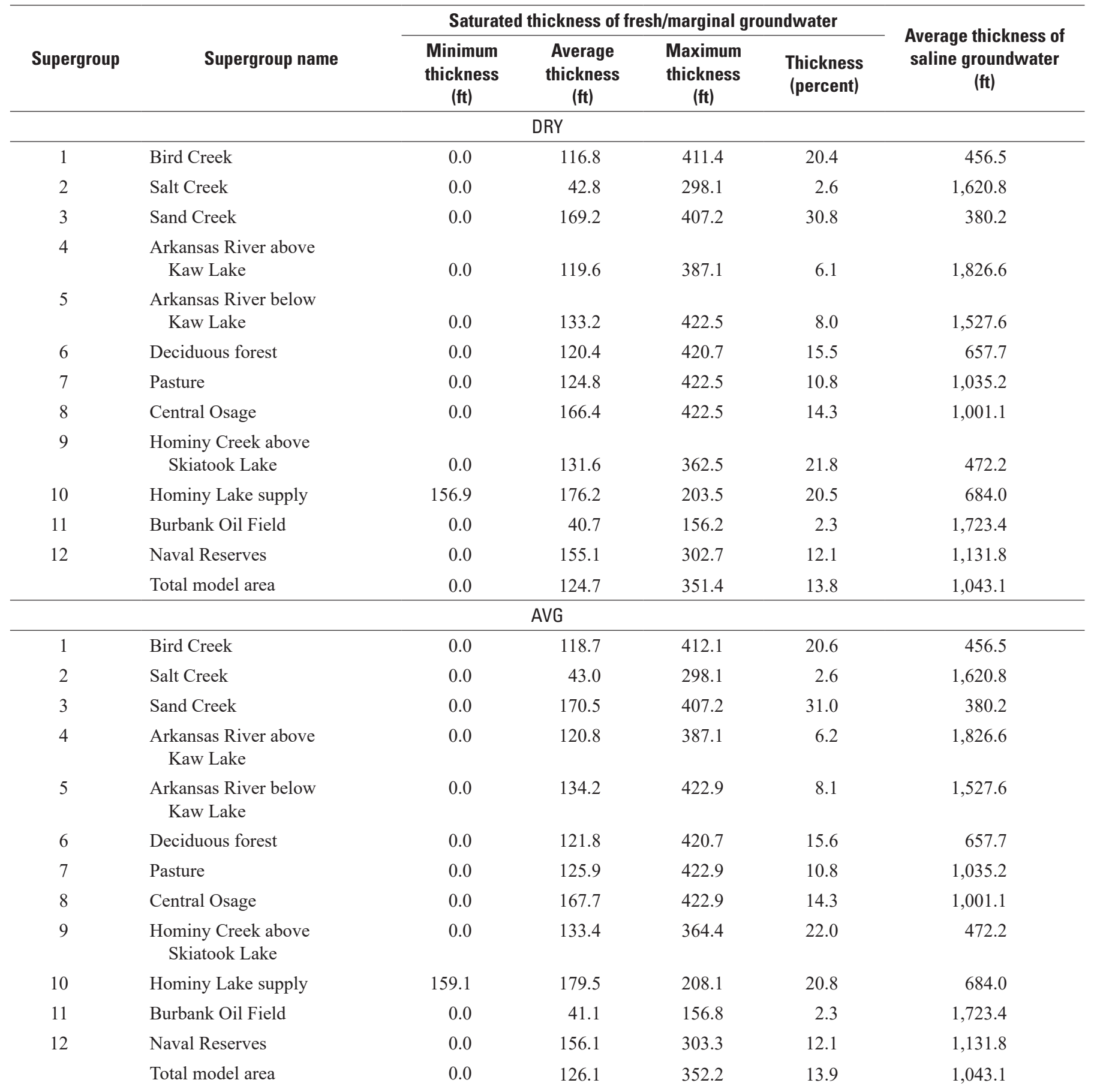


Table 18. Summary of simulated saturated thickness of the fresh/marginal and saline groundwater for each forecast by supergroup of the Osage Nation Integrated Hydrologic Model.-Continued

[ft, foot thickness, in percent, percentage of total saturated thickness that is fresh/marginal groundwater calculated as follows: average thickness of fresh/ marginal groundwater divided by (average thickness of fresh/marginal groundwater + average thickness of saline groundwater) multiplied by 100; DRY, dry forecast; AVG, average forecast; WET, wet forecast]

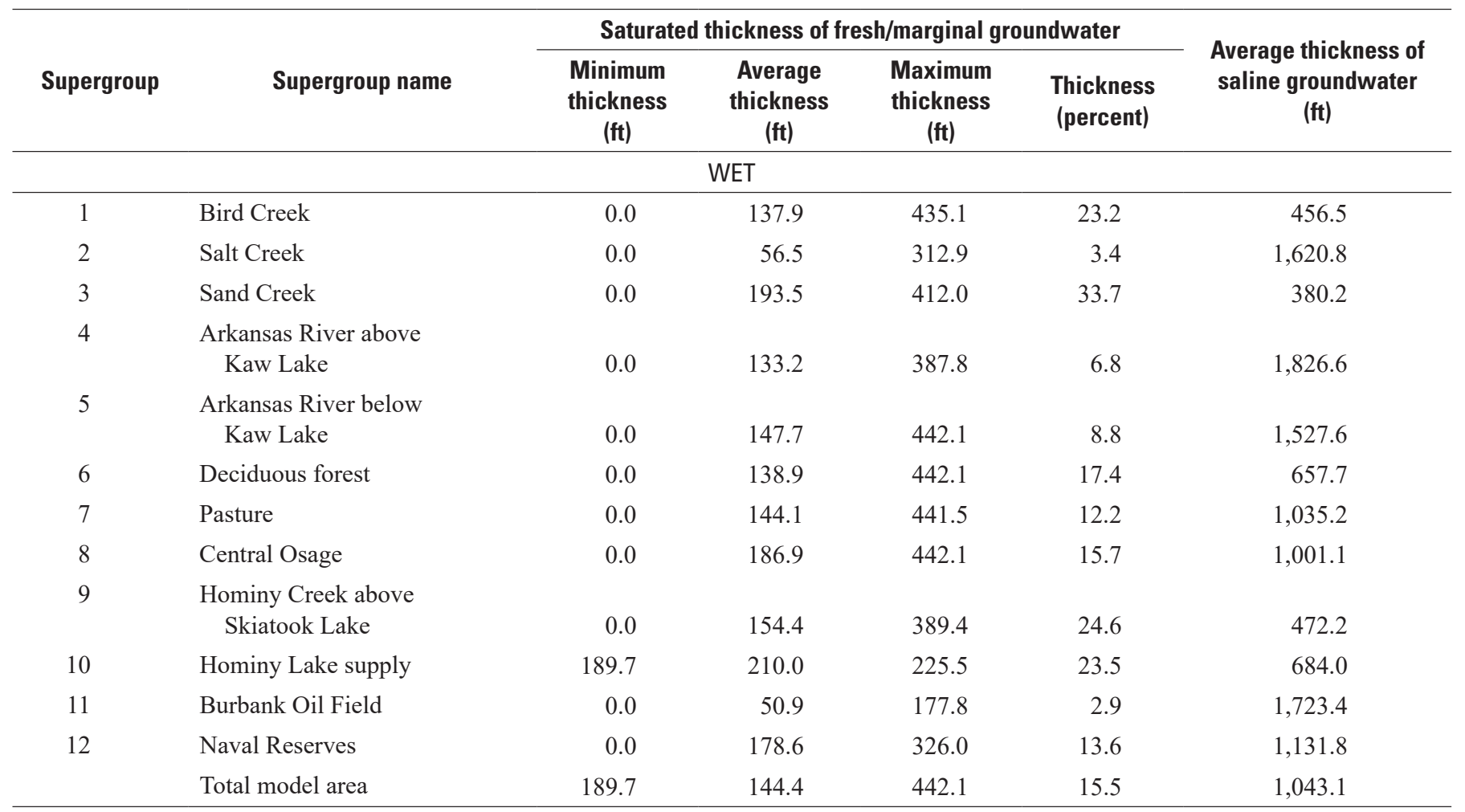




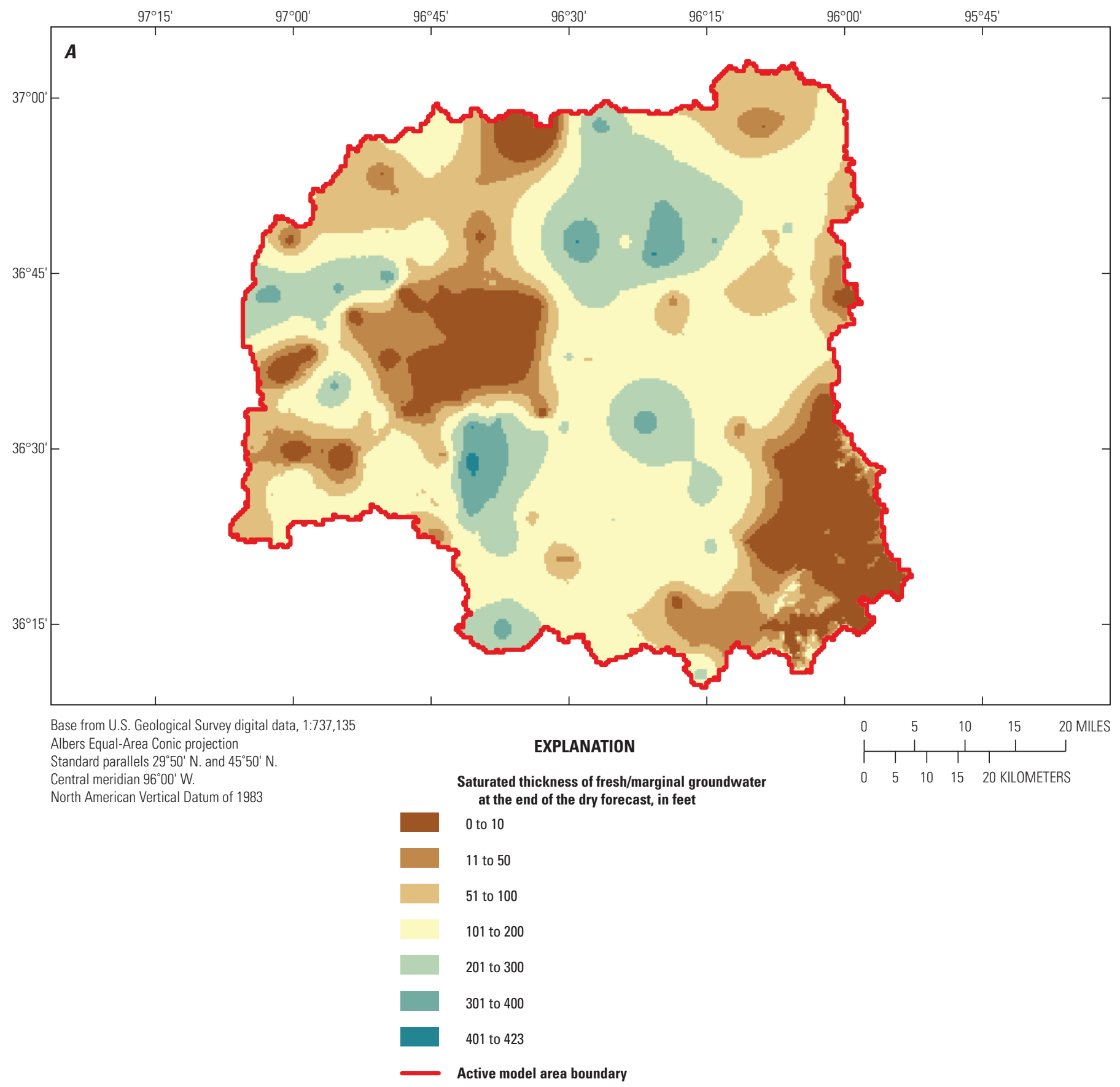

Figure 30. Simulated saturated thickness of fresh/marginal groundwater for the Osage Nation Integrated Hydrologic Model. $A$, dry forecast; $B$, average forecast; and $C$, wet forecast. 


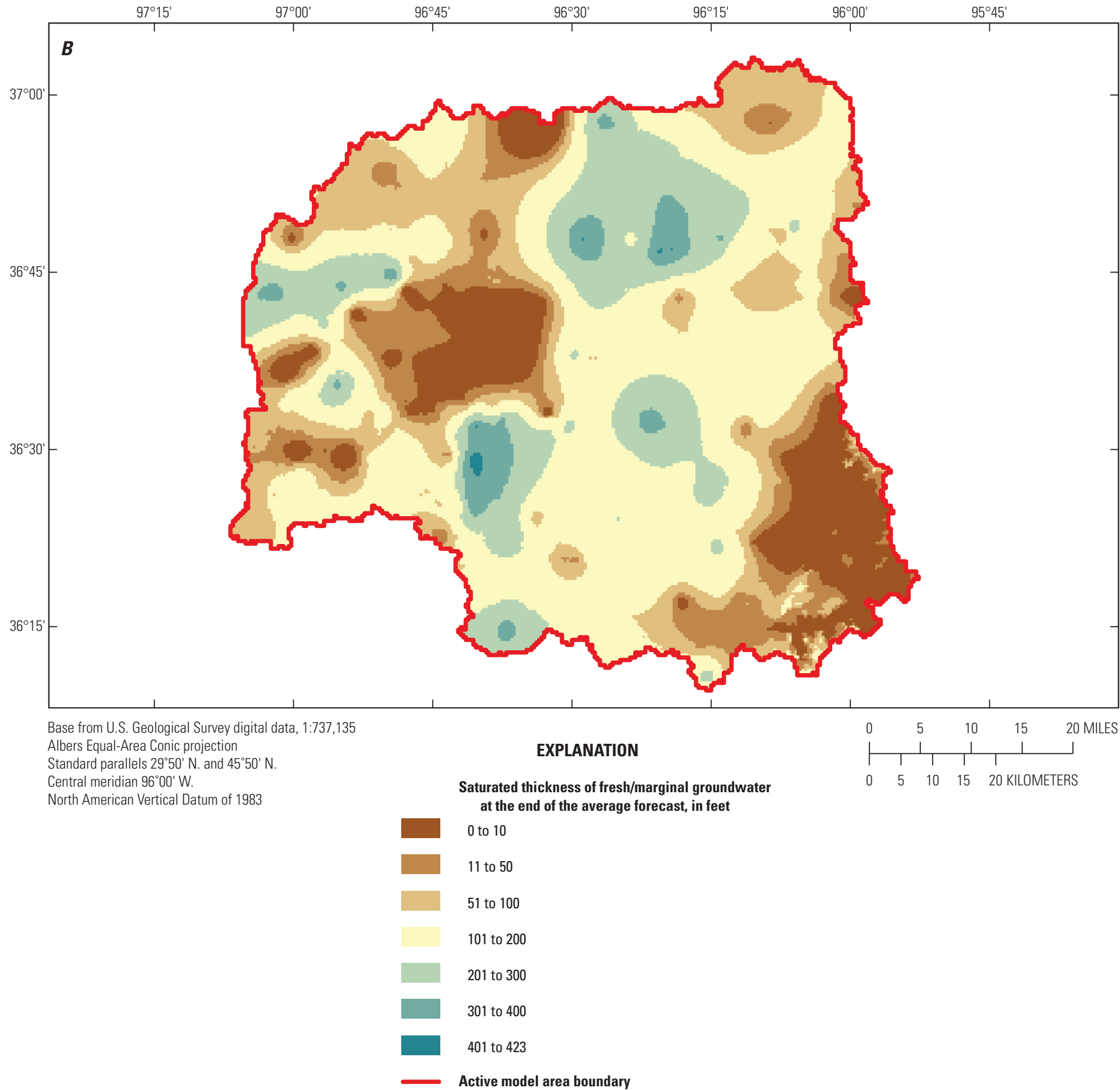

Figure 30. Simulated saturated thickness of fresh/marginal groundwater for the Osage Nation Integrated Hydrologic Model. $A$, dry forecast; $B$, average forecast; and $C$, wet forecast.-Continued 


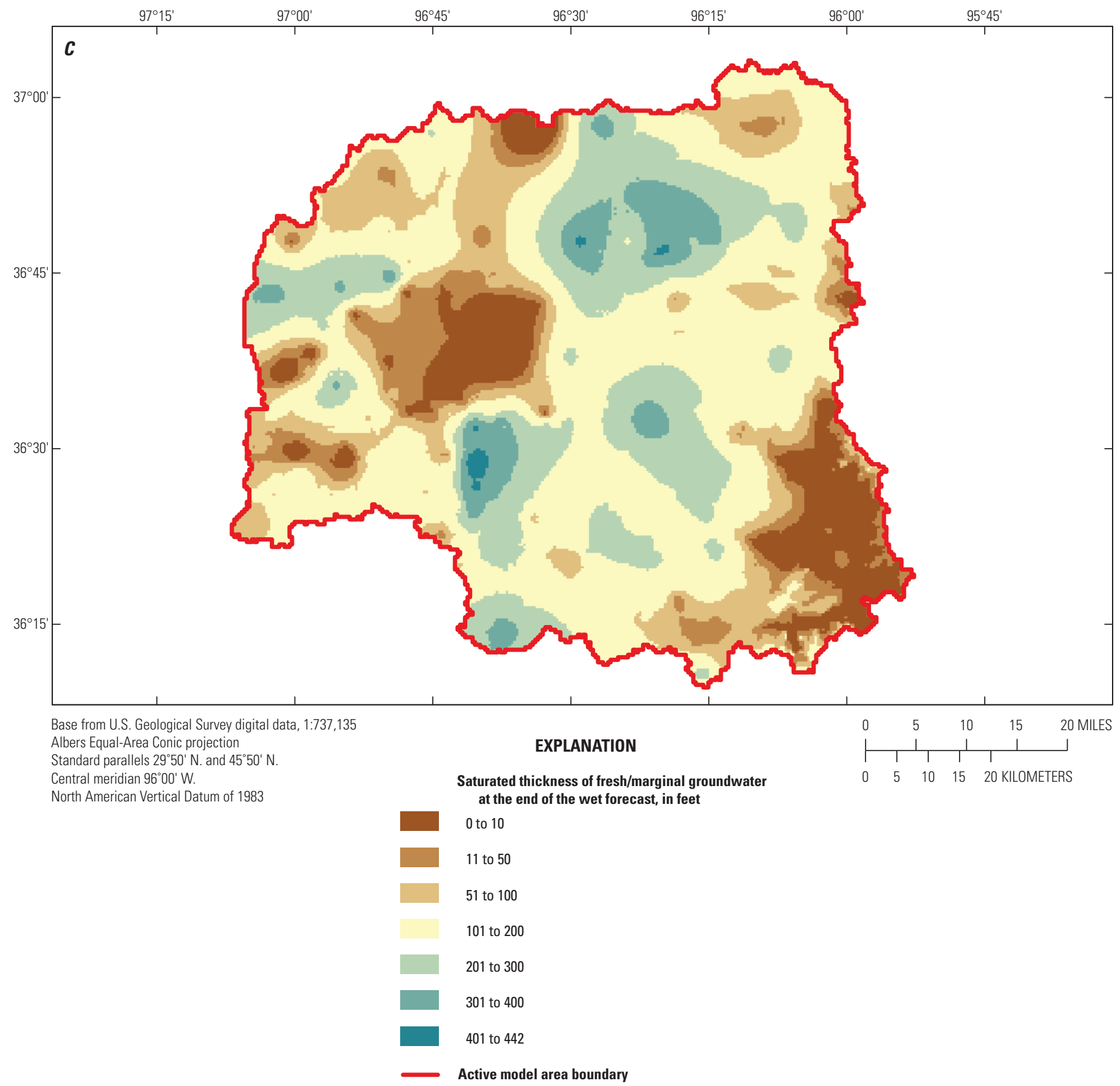

Figure 30. Simulated saturated thickness of fresh/marginal groundwater for the Osage Nation Integrated Hydrologic Model. $A$, dry forecast; $B$, average forecast; and $C$, wet forecast.-Continued 


\section{Assumptions and Limitations}

The fully integrated hydrologic model detailed in this report, called the ONIHM, was developed and calibrated with a "beta" version of the MF-OWHM code because the latest version, MF-OWHM 2.0, was not yet available. The results in this report for the 1950-2014 period ONIHM and the three forecasts were generated by running the ONIHM with the "beta" code. In June 2020, the ONIHM was tested with the MF-OWHM 2.0 code (version 2.0.1) (Traylor and Peterson, 2021; Boyce, in press) and the final stress period cumulative budget outputs were compared between the "beta" and version 2.0.1 codes; differences in the final stress period cumulative budget outputs using the "beta" code versus using the MF-OWHM 2.0.1 (Boyce, in press) are small (less than 0.15 -percent difference) and do not affect the results and conclusions of this report.

The ONIHM was also constructed to simulate the important hydrologic processes for the Osage Nation, conterminous with Osage County, Okla. The spatial and temporal resolutions of the ONIHM are adequate to simulate and characterize semiregional scale processes. Local hydrologic processes may not have been represented or were combined with more regional processes; for example, ephemeral channels were not simulated in this model, and runoff that flows to these channels during precipitation events was instead routed directly to the closest perennial stream. The temporal discretization of monthly stress periods only allows the model to simulate the prevailing average conditions each month. Consequently, this model should not be used to study any hydrologic processes with less than a 1-month duration such as the peak flows of streams during daily precipitation events such as thunderstorms that produce heavy rainfall in a few minutes or hours. Additionally, model cell size limits the characterization of hydrologic properties and features to greater than or equal to 40 acres. Any properties of features less than 40 acres may have been combined with other features; for example, it is common to have multiple land-use types within a 40 -acre cell, and in this model, the major land-use type for each cell was selected to represent the entire cell.

The lack of adequate measured groundwater-level data affected model construction and calibration. There were no data available for water-level measurements in the study area before 1968. Additionally, there were not many observation wells with water levels recorded at deeper hydrostratigraphic layers or in any layer in the northwestern or southeastern regions of the model. During model calibration, the automated PEST software changes parameters to improve the fit between the calibration targets with their simulated equivalents. If there are regions or layers of the active model that do not have calibration targets, then the calibration focuses on reducing the residuals in more observation-dense regions. This focus can potentially bias calibration results of the model to areas with more calibration targets.

Accuracy of the picks for the base of marginal groundwater were difficult to determine because of the age of the geophysical logs; error associated with using resistivity, spontaneous potential, and gamma ray signatures to identify a defined total dissolved solids concentration within the saline transition zone on the geophysical logs; and an unknown method used to determine land-surface elevation. Therefore, the choice of the base of marginal groundwater was estimated to be within plus or minus $50 \mathrm{ft}$ of the actual $1,500-\mathrm{mg} / \mathrm{L}$ dissolved solids concentration occurrence. The Oklahoma base of treatable groundwater map (total dissolved solids concentration less than $10,000 \mathrm{mg} / \mathrm{L}$ ) was used as a guideline for estimating the base of marginal groundwater (total dissolved solids concentration less than $1,500 \mathrm{mg} / \mathrm{L}$ ) outside the perimeter of Osage County with the assumption that the base of marginal groundwater estimated in this study was always shallower than the base of treatable groundwater (Oklahoma Corporation Commission, 2012). To better map the marginal groundwater zones or saline groundwater zones in the future, additional groundwater samples from the marginal groundwater and saline groundwater zones would need to be sampled and analyzed for dissolved solids, major ions, or salinity. These additional groundwater quality samples would also help to form a relationship between water quality and the airborne electromagnetic resistivity data and model reported in Hudson and others (2016); this relationship could be used to improve the demarcation between marginal and saline groundwater within the airborne electromagnetic survey area.

Additionally, the lack of groundwater-level data or water-table maps from previous studies along and outside of the active model boundary limited the characterization of the groundwater-flow directions at the boundary of the active model domain. This lack of data made it difficult to accurately assess whether there was a substantial amount groundwater flow across the model boundary that needed to be specified as a constant head or flux boundary in the model rather than as a no-flow boundary. It is difficult to assess the effect of a noflow boundary on the model results compared to cross-boundary flow, but it is possible that some of the low bias of simulated groundwater levels could be attributed to the absence of cross-boundary flow from outside the model domain. The simulated water-table map generated from groundwater levels from the final stress period of the 1950-2014 period (September 2014) indicated that there may be groundwater inflow to the ONIHM active model along the northwestern, southwestern, and southern model boundaries. This inflow may have affected simulated groundwater levels and base flow to streams during the calibration and forecast periods and caused an underestimation of those groundwater-flow components. The calibration results exhibited a low bias in the calibrated groundwater levels for each layer of the ONIHM. This low bias in calibrated groundwater levels may have caused the model to simulate many reaches of several streams as losing stream water back into the aquifer instead of gaining water as base flow that discharged to the stream. Therefore, systematic underestimation of groundwater levels and base flow in this study are conservative estimates of the water availability for the Osage Nation. Additionally, the low bias in simulated 
groundwater-levels may have partially contributed to the similar groundwater budget flux magnitudes and trends for the dry and average forecasts compared to the wet forecast. The low bias in groundwater levels for the 1950-2014 period ONIHM provided initial conditions for the forecast and were similar to the dry forecast equilibrium, and because of the low amount of recharge for the dry and average forecasts, the replenishment to storage was limited. Conversely, the wet forecast provided enough recharge to the groundwater to replenish storage and increase groundwater levels which caused the difference in flux magnitudes and trends.

Many streamflow observations and specified inflows to the SFR network were not measured values at streamgages but instead were simulated equivalent values from a PRMS model developed for a larger area that included the ONIHM study area (Hevesi and others, 2020). These observations caused the model calibration to "react" to the calibration results of the PRMS model, which were subject to similar calibration methods as the ONIHM described in this report; however, calibrating to simulated values extracted from another model is less desirable than calibrating to real measured values. Consequently, calibration results for the ONIHM, particularly for streamflow, are affected by any bias in the PRMS modelsimulated streamflows. These observations were weighted lower than measured streamflows during calibration to lessen their effect on the calibration, but they are still considered.

The forecast simulations did not incorporate numerical modeling packages that simulate the density changes and behavior of changing water tables and their relation to the saline groundwater interface. The model does not simulate the flow of saline groundwater or the potential transient conditions of the saline groundwater interface for the 1950-2014 period and the forecasts. Therefore, the fresh/marginal groundwater saturated thickness results presented and discussed for the calibration model and forecast simulations are generalized results and trends that are snapshots of the transient system.

\section{Potential Topics for Future Studies}

Characterization of the fresh/marginal groundwater interface across the study area was challenging because of the limited data available. Additional groundwater-quality data across the study area and at varying depths would facilitate a more confident and detailed characterization of the fresh/marginal groundwater interface. Therefore, an investigation to characterize the fresh/marginal groundwater interface in the Osage Nation that includes a field investigation with data collection and simulation of the interface using numerical tools such as the SWI2 Package for MODFLOW-2005 would improve the characterization and understanding of the fresh/marginal groundwater interface and its role in groundwater availability (Bakker and others, 2013). The SWI2 Package, which simulates vertically integrated variable-density groundwater flow, can be implemented into the ONIHM and would increase the capability of the model to simulate the fresh/marginal groundwater interface.

Additionally, collection of more groundwater levels along the boundary of the study area would improve the understanding of groundwater-flow directions across the active model boundary that would benefit further model development. Also, collecting more groundwater levels in the northwestern and southeastern regions of the study area and at deeper depths would improve the model calibration and improve the quantification of model uncertainty. A data-worth analysis could be conducted to identify the most beneficial locations to collect additional groundwater level data that would improve the ONIHM calibration. The data-worth analysis, which can be done using the current version of the ONIHM, would focus on the worth or value of new data collected by quantifying the reduction in prediction uncertainty achieved by adding groundwater-level observations (Fienen and others, 2010).

The forecasts simulated in this study were theoretical and used to assess end member trends and results that demonstrated the response of the hydrologic system to the constant 86-year dry, average, and wet conditions. The results of each forecast described in this report were relative to the calibration model results and to the average conditions forecast. A comparison of those results was used to understand the response of regions in the study area to those forecast stresses. Although it is impossible to predict the future climate, an in-depth study of the effects of more detailed future climate conditions on recharge, runoff, ET, groundwater storage, stream leakage, and freshwater saturated thickness and availability would improve the understanding of the response of the system to those potential forecasts. More detailed potential climate forecasts may include various distributions of precipitation during a single year and (or) multiple years.

\section{Summary}

The Osage Nation of northeastern Oklahoma, conterminous with Osage County, covers about 2,900 square miles. The area is primarily rural with 62 percent of the land being native prairie grass, and much of the area is used for cattle ranching and extraction of petroleum and natural gas. Crop production is minimal and constitutes less than 5 percent of the total land use; groundwater irrigation of crops is minimal and limited to less than 1 percent of total groundwater use in 2010, with most of the wells in the Arkansas River alluvial aquifer. Protection of water rights are important to the Osage Nation because of its reliance on cattle ranching and the potential for impairment of water quality by petroleum extraction. Additionally, the potential for future population increases, demands for water from neighboring areas such as the Tulsa metropolitan area, and expansion of petroleum and natural-gas extraction on water resources of this area further the need for the Osage Nation to better understand its water availability. Therefore, the U.S. Geological Survey, in cooperation with the 
Osage Nation, completed a hydrologic investigation to assess the status and availability of surface-water and groundwater resources in the Osage Nation.

The conceptual model of the hydrologic processes in the study area is characterized by major inflows to the study area from precipitation and streams, with most of the annual precipitation running off the landscape and into the streams or evapotranspired by plants. Streamflows measured at streamgages demonstrated a "flashy" signal that resulted from short-duration intense precipitation events, such as thunderstorms that are common in the spring and summer months. Annual recharge of precipitation to the water table is minimal and occurred mostly in topographically low areas like stream valleys, particularly along the Arkansas River alluvium. Base-flow analysis indicated that the Arkansas River is "losing" stream along some reaches and gaining along others and that smaller streams are "gaining" throughout the study area. Groundwater-level data were minimal in the study area, but groundwater-level hydrographs from wells in the alluvial aquifers indicated small seasonal variations with little waterlevel change. Groundwater-level hydrographs from bedrock aquifers like the Vamoosa-Ada aquifer indicated mostly static trends or minimal seasonal variation in water levels where the aquifer units outcrop and receive some recharge from precipitation. Previous studies determined groundwater-flow in the Arkansas River alluvial aquifer and Vamoosa-Ada aquifer was in a general west to east direction and toward nearby streams.

Based on the conceptual model, a transient integrated hydrologic-flow model was constructed using the U.S. Geological Survey fully integrated, modular, three-dimensional, finite-difference landscape and integrated hydrologic-flow model called the MODFLOW One-Water Hydrologic Model. The integrated hydrologic-flow model, called the Osage Nation Integrated Hydrologic Model (ONIHM), was constructed and uses an orthogonal grid of 276 rows and 289 columns, and each grid cell measures 1,312.34 feet (ft; 400 meters) per side, with eight variably thick vertical layers that represented the alluvial and bedrock aquifers within the study area, including the alluvial aquifer, the Vamoosa-Ada aquifer, and the minor Pennsylvanian bedrock aquifers, and the confining units. Landscape and groundwater-flow processes were simulated for two periods: (1) the 1950-2014 period from January 1950 through September 2014 and (2) the forecast period from October 2014 through December 2099. The 1950-2014 period ONIHM simulated past conditions using measured or estimated inputs, and the forecast-period ONIHM simulated three separate potential forecast conditions under constant dry, average, or wet climate conditions using calibrated input values from the 1950-2014 period ONIHM.

The 1950-2014 period ONIHM was calibrated using Parameter Estimation software (PEST) that uses statistical techniques to find the best combination of parameter values to minimize the fit between measured calibration targets and their simulated equivalent values. The 1950-2014 period ONIHM was calibrated to calibration targets that included 713 measured groundwater levels at 195 wells; 95,636 estimated monthly mean groundwater levels at 124 wells; 5,307 measured streamflows at 13 streamgages; and 8,679 simulated mean monthly streamflows at 10 streamgages extracted from a surface-water model. To improve the fit between the calibration targets and their simulated equivalent values, 231 parameters, including climate, land use, stream, and aquifer properties, were adjusted during calibration. Tikhonov regularization was applied during calibration to impose a penalty on the objective function when PEST deviates parameter values from their user-specified initial values. As a result, PEST was affected by the initial parameter values and deviated from the initial parameter values when the reduction in the objective function was larger than the deviation penalty imposed on the objective function. Additionally, the automated calibration was facilitated with the singular-value decomposition-assist feature of PEST where the 231 individual parameters were grouped into 40 "superparameters" to reduce the number of calibration parameters during the automated calibration phase and improve calibration runtime.

A comparison of the calibration targets to their simulated equivalent values indicated that the model underestimated streamflows and groundwater levels. In spite of this, the model demonstrated a good fit with a coefficient of determination of 0.938 for streamflows and an acceptable fit for groundwater levels with a coefficient of determination of 0.795 . The 1950-2014 period ONIHM-calibrated mean horizontal hydraulic conductivity for the layer 1 alluvial aquifer was 30.7 feet per day, and the seven lower layers had a calibrated mean horizontal hydraulic conductivity of less than 3.3 feet per day, which was consistent with the conceptual model and hydrostratigraphy of the area. Scale factors on potential evapotranspiration were the most sensitive parameters because the largest changes from initial values were the parameters for January, February, November, and December, which increased between 179 and 253 percent.

The ONIHM simulated landscape fluxes of precipitation, groundwater applied by irrigation wells, evapotranspiration from precipitation, groundwater, irrigation, runoff from precipitation, and deep percolation from precipitation. Simulated mean annual evapotranspiration of precipitation was about 31.2 inches (in.), which accounted for about 85 percent of the annual precipitation and was about 9 percent higher than the conceptual model. The remining precipitation not evapotranspired was partitioned into deep percolation (recharge to the water table) and runoff to streams. Simulated mean annual recharge was about 149 cubic feet per second $\left(\mathrm{ft}^{3} / \mathrm{s}\right)$ or $0.70 \mathrm{in}$., and mean annual runoff was about $998 \mathrm{ft}^{3} / \mathrm{s}$ or $4.7 \mathrm{in.}$ Simulated mean annual evapotranspiration from groundwater was about $307 \mathrm{ft}^{3} / \mathrm{s}$ or $1.4 \mathrm{in}$. Irrigation water applied to the landscape was minimal and only accounted for $2.8 \mathrm{ft}^{3} / \mathrm{s}$ or 0.01 inch per year, when spread over the active model domain.

The ONIHM simulated groundwater fluxes of storage, stream leakage, withdrawals from production wells and irrigation wells, and differences in deep percolation and evapotranspiration from groundwater (farm net recharge). Simulated farm net recharge was the largest flux in the groundwater-flow 
system with a mean annual net outflow of $153.4 \mathrm{ft}^{3} / \mathrm{s}$. Outflows to farm net recharge indicated that evapotranspiration from the water table was greater than the recharge to the water table. Simulated stream leakage was the second largest flux in the groundwater-flow system with a mean annual net inflow of $152.5 \mathrm{ft}^{3} / \mathrm{s}$, which demonstrated that, on average, the groundwater/surface-water interaction is a "losing" system where stream water leaks into the subsurface and recharges the water table which was a substantial deviation from the conceptual model. Simulated monthly trends demonstrated that net stream leakage was the largest inflow to the groundwaterflow system for 10 of the 12 months; for the other 2 months (January and March), net farm net recharge (January) and net storage (March) were the largest inflow to the groundwaterflow system. Simulated mean annual net storage inflow to the groundwater-flow system was $14.7 \mathrm{ft}^{3} / \mathrm{s}$, which demonstrated that on average groundwater was released from storage and resulted in declining water levels throughout the 1950-2014 period ONIHM simulation.

A base of marginal groundwater map was created for the study and compared to the water-table map created from groundwater levels at the end of the calibration model to identify the presence of fresh/marginal groundwater throughout the study area. Mean fresh/marginal groundwater saturated thickness was $135 \mathrm{ft}$ and ranged from 0 to $438.2 \mathrm{ft}$. The thickest regions of fresh/marginal groundwater were near the region of the Arkansas River below Ralston, Oklahoma, and the upper Sand Creek watershed.

The calibrated 1950-2014 period ONIHM simulated three forecasts to assess the effects of potential climatic changes on the hydrologic system from October 2014 to December 2099. The three forecasts simulated theoretical dry, average, and wet conditions using precipitation and PET datasets from selected years in the calibrated 1950-2014 period ONIHM. Annual precipitation amounts were 26.89, 35.47, and 50.73 in. for the dry, average, and wet forecasts, respectively. Like the calibration model, forecast results for the landscape demonstrated that evapotranspiration from precipitation (sum of evaporation and transpiration from precipitation) was the largest flux from the landscape for all three forecasts, constituting about 95, 95, and 77 percent of precipitation for the dry, average, and wet forecasts, respectively. Landscape and flux magnitudes were similar for dry and average climate forecasts because evapotranspiration of precipitation was about the same, over the dry and average forecasts, which left minimal amounts of precipitation to run off the landscape or recharge the water table as deep percolation. The 77 percent of precipitation that evapotranspired in the wet forecast left substantially more water to run off the landscape and into streams or recharge the water table as deep percolation compared to the dry and average forecast.

Annual groundwater fluxes varied for each forecast and supergroup. Groundwater fluxes were several orders of magnitude less than many landscape fluxes. Groundwater fluxes demonstrated similar trends for the dry and average climate forecasts that were characterized by inflows to the groundwater-flow system from storage and from stream leakage. These inflows for the dry and average climate corresponded to decreasing groundwater levels and "losing" streams throughout the simulations. Conversely, the wet forecast was characterized by outflows from the groundwaterflow system and indicated a replenishment to groundwater storage throughout the simulation, which resulted in increasing groundwater levels. The Arkansas River upstream and downstream from Kaw Lake was a "losing" stream for all forecasts, whereas Bird Creek was a "losing" stream for the dry and average climate forecasts and a "gaining" stream for the wet climate forecast.

Landscape and groundwater-flow budgets for each forecast were created for each of the 12 supergroups in the ONIHM and demonstrated many similar trends to the study area budgets. Land use was an important factor in the forecast landscape water budgets and affected evapotranspiration of precipitation such that generally the supergroups with the highest amount of pasture (Pasture, Burbank Oil Field, and Naval Reserves) also had the highest percentage of evapotranspiration from precipitation, and, conversely, the supergroups with more deciduous forest (Deciduous forest, Bird Creek, and Sand Creek) had less evapotranspiration from precipitation. Further, the regions with more pasture and higher evapotranspiration from precipitation had lower percentages of runoff and deep percolation than regions with more deciduous forest.

Like the landscape water budgets, groundwater-flow budget components followed the same trends for the dry and average forecasts across most supergroups. The dry and average forecast groundwater-flow budgets were characterized by inflows to the groundwater-flow system from storage and stream leakage and outflows from the groundwater-flow system to farm net recharge. Only three supergroups (Sand Creek, Central Osage, and Burbank Oil Field) demonstrated outflows from the groundwater-flow system to stream leakage for the DRY and AVG forecasts (table 17) that demonstrated "gaining" conditions.

Simulated water-table maps created from the groundwater levels from the final stress period (December 31, 2099) for each forecast indicated that groundwater-flow directions for each forecast were consistent with the groundwater-flow directions at the end of the 1950-2014 period. The water table was similar for the dry and average forecasts for most of the study area. The wet forecast groundwater-level contours migrated eastward because groundwater levels were higher than the dry and average forecasts. Supergroups in the eastern and central regions, such as Bird Creek, Sand Creek, and Hominy Creek above Skiatook Lake, experienced the largest spatial changes in the water table, whereas the Arkansas River supergroups demonstrated more stable water tables for each forecast.

The base of the marginal water map was compared to the water-table map created from the final stress period (December 2099) groundwater levels for each climate forecast to identify the presence of fresh/marginal groundwater throughout the study area. Mean dry, average, and wet climate forecast 
fresh/marginal groundwater saturated thicknesses for the final stress period of each simulation were about 125,126 , and $144 \mathrm{ft}$, respectively, and ranged from 0 to $442 \mathrm{ft}$. The spatial extents of saline water at the end of the forecast (December 2099) did not change substantially from the end of the calibration model period (September 2014).

\section{Selected References}

Abbott, M.M., and DeHay, K., 2008, Aquifer tests and characterization of transmissivity, Ada-Vamoosa Aquifer on the Osage Reservation, Osage County, Oklahoma, 2006: U.S. Geological Survey Scientific Investigations Report 2008-5118, 10 p. [Also available at https://doi.org/10.3133/ sir20085118.]

Abbott, M.M., and Tortorelli, R.L., 2002, Surface-water characteristics and quality on the Osage Reservation, Osage County, Oklahoma, 1999: U.S. Geological Survey WaterResources Investigations Report 02-4060, 69 p. [Also available at https://doi.org/10.3133/wri024060.]

Allen, R.G., Pereira, L.S., Smith, M., Raes, D., and Wright, J.L., 2005, FAO-56 dual crop coefficient method for estimating evaporation from soil and application extensions: Journal of Irrigation and Drainage Engineering, v. 131, no. 1, p. 2-13, accessed April 2017 at https://doi.org/10.1061/(ASCE)0733-9437(2005)131:1(2).

American Nuclear Society, 1980, American national standard for evaluation of radionuclide transport in groundwater for nuclear power sites, version 1.1 (revised May 26, 2010): La Grange Park, Ill., American Nuclear Society, ANS-2.17$1980,57 \mathrm{p}$.

Andrews, W.J., and Smith, S.J., 2014, Description of landscape features, summary of existing hydrologic data, and identification of data gaps for the Osage Nation, northeastern Oklahoma, 1890-2012: U.S. Geological Survey Scientific Investigations Report 2014-5134, 53 p. [Also available at https://doi.org/10.3133/sir20145134.]

Asquith, G., and Gibson, C., 1982, Basic well log analysis for geologists: Tulsa, Okla., American Association of Petroleum Geologists, Methods in Exploration Series, no. 3, 215 p.

Bakker, M., Schaars, F., Hughes, J.D., Langevin, C.D., and Dausman, A.M., 2013, Documentation of the seawater intrusion (SWI2) package for MODFLOW: U.S. Geological Survey Techniques and Methods, book 6, chap. A46, 47 p. [Also available at https://pubs.usgs.gov/tm/6a46/.]

Barlow, P.M., Cunningham, W.L., Zhai, T., and Gray, M., 2015, U.S. Geological Survey Groundwater Toolbox, a graphical and mapping interface for analysis of hydrologic data (version 1.0) - User guide for estimation of base flow, runoff, and groundwater recharge from streamflow data: U.S. Geological Survey Techniques and Methods, book 3, chap. B10, 27 p., accessed June 2016 at https://doi.org/10.3133/tm3B10.
Bass, N.W., Dillard, W.R., Kennedy, L.E., and Goodrich, H.B., 1941, Subsurface geology and oil and gas resources of Osage County, Oklahoma Part 9. Townships 23 and 24 North Range 7 East: U.S. Geological Survey Bulletin 900-I, p. 303-319. [Also available at https://doi.org/10.3133/ b900I.]

Bingham, R.H., and Bergman, D.L., 1980, Reconnaissance of the water resources of the Enid quadrangle, north-central Oklahoma: Oklahoma Geological Survey Hydrologic Atlas 7, 4 pls., scale 1:250,000. [Also available at http://www.ou.edu/ogs/maps/hydrologicatlases.]

Boyce, S.E., [in press], MODFLOW One-Water Hydrologic Flow Model (MF-OWHM) conjunctive use and integrated hydrologic flow modeling software, version 2.0.1: U.S. Geological Survey Software Release, https://doi.org/10.5066/P9P8I8GS.

Boyce, S.E., Hanson, R.T., Ferguson, I., Schmid, W., Henson, W., Reimann, T., Mehl, S.M., and Earll, M.M., 2020, One-Water Hydrologic Flow Model-A MODFLOW based conjunctive-use simulation software: U.S. Geological Survey Techniques and Methods 6-A60, 458 p. [Also available at https://doi.org/10.3133/tm6A60.]

Boyd, D.T., 2011, J. Glenn Cole-A stratigraphic legacy preserved: Shale Shaker-The Journal of the Oklahoma City Geological Society, v. 61, no. 6, p. 329-336.

Brown, S.L., 1967, Stratigraphy and depositional environment of the Elgin Sandstone (Pennsylvanian) in south-central Kansas: Kansas Geological Survey Bulletin 187, part 3, 9 p. [Also available at http://129.237.140.42/Publications/ Bulletins/187_3/index.html.]

Canadell, J., Jackson, R.B., Ehleringer, J.B., Mooney, H.A., Sala, O.E., and Schulze, E.-D., 1996, Maximum rooting depth of vegetation types at the global scale: Oecologia, v. 108, no. 4, p. 583-595. [Also available at https://doi.org/10.1007/BF00329030.]

Carter, J.M., Driscoll, D.G., Williamson, J.E., and Lindquist, V.A., 2002, Atlas of water resources in the Black Hills area, South Dakota, U.S. Geological Survey Hydrologic Investigations Atlas HA-747, accessed November 2019 at https://doi.org/10.3133/ha747.

Chow, V.T., 1959, Open channel hydraulics: New York, McGraw-Hill, 680 p.

Cohen, F.S., 1982, Felix S. Cohen's handbook of Federal Indian law: Charlottesville, Va., Lexis Law Publishing, $912 \mathrm{p}$.

Condor Team, 2012, Condor version 7.6.6 manual—-Technical report: Madison, Wis., University of Wisconsin, 1,005 p.

D’Lugosz, J.J., McClaflin, R.G., and Marcher, M.V., 1986, Geohydrology of the Vamoosa-Ada aquifer east-central Oklahoma: Oklahoma Geological Survey Circular 87, 42 p. 
Doherty, J.E., 2009, Groundwater data utilities-Part B, program descriptions: Brisbane, Australia, Watermark Numerical Computing, accessed December 2017 at http://www.pesthomepage.org/Downloads.php.

Doherty, J.E., 2016, PEST, model independent parameter estimation-User manual (5th ed.): Brisbane, Australia, Watermark Numerical Computing, accessed December 2017 at http://www.pesthomepage.org/Downloads.php.

Doherty, J.E., and Hunt, R.J., 2010, Approaches to highly parameterized inversion-A guide to using PEST for groundwater-model calibration: U.S. Geological Survey Scientific Investigations Report 2010-5169, 59 p. [Also available at https://doi.org/10.3133/sir20105169.]

Domenico, P.A., and Schwartz, F.W., 1990, Physical and chemical hydrogeology: New York, John Wiley \& Sons, $824 \mathrm{p}$.

Ellis, J.H., Mashburn, S.L., Graves, G.M., Peterson, S.M., Smith, S.J., Fuhrig, L.T., Wagner, D.L., and Sanford, J.E., 2017, Hydrogeology and simulation of groundwater flow and analysis of projected water use for the Canadian River alluvial aquifer, western and central Oklahoma (ver. 1.1, March 2017): U.S. Geological Survey Scientific Investigations Report 2016-5180, 64 p., 7 pls. [Also available at https://doi.org/10.3133/sir20165180.]

Fenneman, N.M., and Johnson, D.W., 1946, Physical divisions of the conterminous United States: U.S. Geological Survey, 1 sheet, scale 1:7,000,000. [Also available at https://water.usgs.gov/GIS/metadata/usgswrd/XML/ physio.xml\#stdorder.]

Fetter, C.W., 2001, Applied hydrogeology, 4th ed.: Upper Saddle River, N.J., Prentice Hall, 598 p.

Fienen, M.N., Doherty, J.E., Hunt, R.J., and Reeves, H.W., 2010, Using prediction uncertainty analysis to design hydrologic monitoring networks-Example applications from the Great Lakes water availability pilot project: U.S. Geological Survey Scientific Investigations Report 2010-5159, 44 p. [Also available at https://doi.org/10.3133/sir20105159.]

Gesch, D., Evans, G., Mauck, J., Hutchinson, J., and Carswell, W.J., Jr., 2009, The National Map-Elevation: U.S. Geological Survey Fact Sheet 2009-3053, 4 p. [Also available at https://pubs.usgs.gov/fs/2009/3053/.]

Hanson, R.T., Boyce, S.E., Schmid, W., Hughes, J.D., Mehl, S.M., Leake, S.A., Maddock, Thomas, III, and Niswonger, R.G., 2014, One-Water Hydrologic Flow Model (MODFLOW-OWHM): U.S. Geological Survey Techniques and Methods, book 6, chap. A51, 120 p., accessed November 2016 at https://doi.org/10.3133/tm6A51.

Harbaugh, A.W., Banta, E.R., Hill, M.C., and McDonald, M.G., 2000, MODFLOW-2000, the U.S. Geological Survey modular ground-water model - User guide to modularization concepts and the ground-water flow process: U.S. Geological Survey Open-File Report 2000-92, 121 p. [Also available at https://doi.org/10.3133/ofr200092.]
Hart, D.L., 1966, Base of fresh groundwater in southern Oklahoma: U.S. Geological Survey Hydrologic Investigations Atlas HA-223, 2 pls. [Also available at https://doi.org/10.3133/ha223.]

Helton, T., 1998, Indian reserved water rights in the dualsystem State of Oklahoma-Tulsa: Law Review, v. 33, no. 3 , article 10, p. 979-1002. [Also available at https://digitalcommons.law.utulsa.edu/cgi/viewcontent.cgi?r eferer $=\&$ httpsredir $=1 \&$ article $=2151 \&$ context $=$ tlr.]

Heran, W.D., Green, G.N., and Stoeser, D.B., 2003, A digital geologic map database for the state of Oklahoma: U.S. Geological Survey Open-File Report 2003-247, accessed June 2018 at https://doi.org/10.3133/ofr03247.

Hevesi, J.A., Hanson, R.T., and Masoner, J.R., 2020, Precipitation Runoff Modeling System (PRMS) as part of an integrated hydrologic model for the Osage Nation, northeastern Oklahoma, 1915-2014: U.S. Geological Survey Scientific Investigations Report 2019-5030, 150 p. [Also available at https://pubs.usgs.gov/sir/2019/5030/sir20195030.pdf.]

Hill, M.C., and Tiedeman, C.R., 2007, Effective groundwater model calibration-With analysis of data, sensitivities, predictions, and uncertainty: Hoboken, N.J., Wiley-Interscience, 455 p. [Also available at https://doi.org/10.1002/0470041080.]

Hillel, D., 1980, Fundamentals of soil physics: New York, Academic Press, 413 p.

Homer, C.G., Dewitz, J.A., Yang, L., Jin, S., Danielson, P., Xian, G.Z., Coulston, J., Herold, N.D., Wickham, J.D., and Megown, K., 2015, Completion of the 2011 National Land Cover Database for the conterminous United StatesRepresenting a decade of land cover change information: Photogrammetric Engineering and Remote Sensing, v. 81, no. 5, p. 345-354. [Also available at https://cfpub.epa.gov/ si/si_public_record_report.cfm?Lab=NERL\&dirEntr yId=309950.]

Hudson, M.R., Smith, D.V., Pantea, M.P., and Becker, C.J., 2016, Geologic and geophysical models for Osage County, Oklahoma, with implications for groundwater resources: U.S. Geological Survey Scientific Investigations Report 2016-5067, 27 p., accessed March 2017 at https://doi.org/10.3133/sir20165067.

Hunt, R.J., Luchette, J., Shreuder, W.A., Rumbaugh, J.O., Doherty, J., Tonkin, M.J., and Rumbaugh, D.B., 2010, Using a cloud to replenish parched groundwater modeling efforts: Ground Water, v. 48, no. 3, p. 360-365. [Also available at https://doi.org/10.1111/j.1745-6584.2010.00699.x.]

Jewett, M., Emery, P.A., and Hatcher, D.A., 1965, The Pleasanton Group (Upper Pennsylvanian) in Kansas: Kansas Geological Survey, Bulletin 175, Part 4. [Also available at http://www.kgs.ku.edu/Publications/Bulletins/175_4/.] 
Johnson, K.S., 1997, Evaporite karst in the United States: Carbonates and Evaporites, v. 12, no. 1, p. 2-14. [Also available at https://link.springer.com/content/pdf/10.1007/ BF03175797.pdf.]

Jordan, L., and Vosburg, D.L., 1963, Permian salt and associated evaporites in the Anadarko basin of the western Oklahoma-Texas Panhandle Region: Oklahoma Geological Survey, Bulletin 102. [Also available at http://www.ogs.ou.edu/ pubsscanned/BULLETINS/Bulletin102mm.pdf.]

Keys, W.S., 1990, Borehole geophysics applied to groundwater investigations: U.S. Geological Survey Techniques of Water-Resources Investigations, book 2, chap. E2, $150 \mathrm{p}$. [Also available at https://doi.org/10.3133/twri02E2.]

Köppen, W., 1936, Das geographische System der Klimate, in Köppen, W., and Geiger, R., eds., Handbuch der Klimatologie, v. 1, part C: Berlin, Verlag von Gebrüder Borntraeger, p. $1-44$.

Marcher, M.V., and Bingham, R.H., 1971, Reconnaissance of the water resources of the Tulsa quadrangle, northeastern Oklahoma: Oklahoma Geological Survey Hydrologic Atlas 2, 4 sheets, scale 1:250,000. [Also available at http://www.ou.edu/ogs/maps/hydrologicatlases.]

Mashburn, S.L., 2003, Arkansas River Quaternary aquifer-Characteristics and water-quality, Osage Reservation, northeastern Oklahoma: Stillwater, Okla., Oklahoma State University, master's thesis, $354 \mathrm{p}$.

Mashburn, S.L., Cope, C.C., and Abbott, M.M., 2003, Aquifer characteristics, water availability, and water quality of the Quaternary aquifer, Osage County, northeastern Oklahoma, 2001-2002: U.S. Geological Survey Water-Resources Investigations Report 03-4235, 48 p. [Also available at https://pubs.usgs.gov/wri/wri034235/.]

Naff, J.D., 1981, Guidebook for geologic field trips in northcentral Oklahoma: Oklahoma Geological Survey, 42 p.

National Climatic Data Center, 2016, Climate data online search-Asheville, N.C.: National Oceanic and Atmospheric Administration digital data, accessed December 29, 2016, at http://www.ncdc.noaa.gov/cdo-web/search.

Niswonger, R.G., Panday, S., and Ibaraki, M., 2011, MODFLOW-NWT, a Newton formulation for MODFLOW-2005: U.S. Geological Survey Techniques and Methods, book 6, chap. A37, 44 p. [Also available at https://doi.org/10.3133/tm6A37.]

Niswonger, R.G., and Prudic, D.E., 2005, Documentation of the streamflow-routing (SFR2) package to include unsaturated flow beneath streams-A modification to SFR1: U.S. Geological Survey Techniques and Methods, book 6, chap. A13, 51 p., accessed November 2016 at https://doi.org/10.3133/tm6A13.
Niswonger, R.G., Prudic, D.E., and Regan, R.S., 2006, Documentation of the Unsaturated-Zone Flow (UZF1) Package for modeling unsaturated flow between the land surface and the water table with MODFLOW-2005: U.S. Geological Survey Techniques and Methods 6-A19, 62 p., accessed April 2018 at https://doi.org/10.3133/tm6A19.

O'Connor, H.G., 1974, Geology and ground-water resources of Montgomery County, southeastern Kansas: Kansas Geological Survey Ground Water Series 1. [Also available at http://www.kgs.ku.edu/Publications/Bulletins/GW1/ index.html.]

Oklahoma Climatological Survey, 2013, The climate of Osage County: Oklahoma Climatological Survey, 8 p., accessed August 8, 2013, at http://climate.ok.gov/county_climate/ Products/County_Climatologies/county_climate_osage.pdf.

Oklahoma Corporation Commission, 2012, Groundwater: Oklahoma Corporation Commission web page, accessed October 2012 at http://www.occ.state.ok.us/ WEBAPPS/w_g27help.html.

Oklahoma Water Resources Board, 2016, Water well record search: Oklahoma Water Resources Board digital data, accessed January 12, 2016, at http://www.owrb.ok.gov/wd/ search/search.php.

Otton, J.K., Asher-Bolinder, S., Owen, D.E., and Hall, L., 1997, Effects of produced waters at oilfield production sites on the Osage Indian Reservation, northeastern Oklahoma: U.S. Geological Survey Open File Report 97-28, 23 p. [Also available at https://doi.org/10.3133/ofr9728.]

Schmid, W., and Hanson, R.T., 2009, The Farm Process Version 2 (FMP2) for MODFLOW-2005-Modifications and upgrades to FMP1: U.S. Geological Survey Techniques and Methods, book 6, chap. A32, 102 p. [Also available at https://pubs.usgs.gov/tm/tm6a32/.]

Schmid, W., Hanson, R.T., Maddock, T., III, and Leake, S.A., 2006, User guide for the farm process (FMP1) for the U.S. Geological Survey's modular three-dimensional finitedifference ground-water flow model, MODFLOW-2000: U.S. Geological Survey Techniques and Methods, book 6, chap. A17, 139 p. [Also available at https://doi.org/10.3133/ tm6A17.]

Smith, O.M., Dott, R.H., and Warkentin, E.C., 1942, The chemical analyses of the water of Oklahoma: Stillwater, Okla., Oklahoma Agricultural and Mechanical College, $474 \mathrm{p}$.

Sohl, T., Reker, R., Bouchard, M., Sayler, K., Dornbierer, J., Wika, S., Quenzer, R., and Friesz, A., 2016, Modeled historical land use and land cover for the conterminous United States: Journal of Land Use Science, v. 11, no. 4, p. 476-499. [Also available at https://doi.org/10.1080/1747 423X.2016.1147619.] 
Sutherland, A., Carlson, J.D., and Kizer, M., 2005, Evapotranspiration product description: Norman, Okla., University of Oklahoma, 15 p., accessed December 28, 2016, at http://www.mesonet.org/images/site/Evapotranspiration\%20 Product\%20Description\%20Mar\%202005.pdf.

Tanner, W.F., 1956, Geology of northeastern Osage County, Oklahoma: Oklahoma Geological Survey Circular no. 40, 76 p. [Also available at http://ogs.ou.edu/docs/circulars/ C40.pdf.]

Traylor, J.P., and Peterson, S.M., 2021, MODFLOWOne Water Hydrologic Model integrated hydrologicflow model used to evaluate water availability in the Osage Nation: U.S. Geological Survey data release, https://doi.org/10.5066/P91OKQ2C.

U.S. Census Bureau, 2003, Oklahoma-2000-Population and housing unit counts - 2000 Census of population and housing: Washington, D.C., U.S. Census Bureau, PHC-3-38, 84 p., accessed July 22, 2017, at https://www.census.gov/ $\mathrm{prod} / \mathrm{cen} 2000 / \mathrm{phc}-3-38 . p d f$.

U.S. Census Bureau, 2013, 2010 census: U.S. Census Bureau web page, accessed August 6, 2013, at www.census.gov/2010census/.

U.S. Census Bureau, 2017, American FactFinder: U.S. Census Bureau digital data, accessed July 22, 2017, at https://factfinder.census.gov/faces/nav/jsf/pages/ index.xhtml.

U.S. Department of Agriculture, 2004, Big bluestem-Plant guide: Natural Resource Conservation Service, 3 p., accessed May 2017 at https://plants.usda.gov/plantguide/ pdf/pg_ange.pdf.

U.S. Department of Agriculture, 2014, Soil Survey Geographic Database (SSURGO) - Geospatial data gateway: Natural Resources Conservation Service web page, accessed March 14, 2013, at http://datagateway.nrcs.usda.gov/. [Also available at https://websoilsurvey.sc.egov.usda.gov/ App/HomePage.htm.]

U.S. Department of Agriculture, 2016, National Agricultural Statistics Service crop data layer, 2005-2014Published crop-specific data layer: U.S. Department of Agriculture digital data, accessed August 30, 2016, at https://nassgeodata.gmu.edu/CropScape/.
U.S. Department of Agriculture, 2017, Range and pasture: U.S. Department of Agriculture, Natural Resources Conservation Service web page, accessed April 2017 at https://www.nrcs.usda.gov/wps/portal/nrcs/main/me/ technical/landuse/pasture/.

U.S. Geological Survey, 2013, National Hydrography Dataset (medium resolution): U.S. Geological Survey, digital data, accessed September 10, 2013, at https://www.usgs.gov/ core-science-systems/ngp/national-hydrography/nationalhydrography-dataset?qt-science_support_page_related_ con $=0 \#$ qt-science_support_page_related_con.

U.S. Geological Survey, 2015, 3DEP products and services: U.S. Geological Survey web page, accessed September 22, 2015, at http://nationalmap.gov/3dep_prodserv.html.

U.S. Geological Survey, 2016, USGS water data for the Nation: U.S. Geological Survey National Water Information System database, accessed January 2016 at https://doi.org/10.5066/F7P55KJN.

Weaver, J.E., 1968, Prairie plants and their environment: Lincoln, Nebr., University of Nebraska Press, 268 p.

Westjohn, D.B., and Weaver, T.L., 1992, Configuration of freshwater/saline-water interface and geologic controls on distribution of freshwater in a regional aquifer system, central lower peninsula of Michigan: U.S. Geological Survey Water-Resources Investigations Report 92-4242, 44 p. accessed May 2018 at https://doi.org/10.3133/wri944242.

Wilkins, K., 1997, Hydrologic report of the east-central Oklahoma minor bedrock groundwater basin in Seminole, Hughes and Okfuskee Counties: Oklahoma Water Resources Board Technical Report 97-2, accessed June 2016 at https://www.owrb.ok.gov/studies/reports/ reports_pdf/TR97_2\%20East\%20Central\%20Minor\%20 GW\%20Basin.pdf.

Williams, J.H., 2017, Tallgrass Prairie Preserve self-guided nature trail: The Nature Conservancy, 9 p., accessed June 2017 at https://www.nature.org/content/dam/tnc/ nature/en/documents/tallgrass-trails-brochure-1.pdf.

Yang, W., Bruemmer, M., and Turner-Williams, M., 2003, Stratigraphic architecture and processes controlling coeval deltaic, platform carbonate, and condensed shelf sedimentation, upper Pennsylvanian, Leavenworth limestone-Heebner shale-Plattsmouth limestone-Heumader shale minor cyclothem, SE Kansas and NE Oklahoma: Tulsa Geological Society, $31 \mathrm{p}$. 
Table 2 
Table 2. Stratigraphic column showing geologic ages; geologic units; hydrostratigraphic units; three-dimensional geology model layer names; Osage Nation Integrated Hydrologic Model (ONIHM) layer name, number; and minimum, mean, and maximum thickness.

[3D, three dimensional; ONIHM, Osage Nation Integrated Hydrologic Model; min, minimum; max, maximum; --, no data]

\begin{tabular}{|c|c|c|c|c|c|c|c|c|c|c|}
\hline \multirow{2}{*}{ System } & \multirow{2}{*}{ Series } & \multirow{2}{*}{ Geologic unit ${ }^{1}$} & \multirow{2}{*}{$\begin{array}{c}\text { Hydrostratigraphic } \\
\text { unit }\end{array}$} & \multirow{2}{*}{$\begin{array}{l}\text { 3D } \\
\text { geology } \\
\text { model } \\
\text { layer } \\
\text { name }^{1}\end{array}$} & \multirow{2}{*}{$\begin{array}{l}\text { ONIHM } \\
\text { layer unit } \\
\text { name }\end{array}$} & \multirow{2}{*}{ Description } & \multirow{2}{*}{$\begin{array}{c}\text { ONIHM } \\
\text { layer } \\
\text { number }\end{array}$} & \multicolumn{3}{|c|}{$\begin{array}{l}\text { ONIHM layer thickness, } \\
\text { in feet }\end{array}$} \\
\hline & & & & & & & & Min & Mean & Max \\
\hline 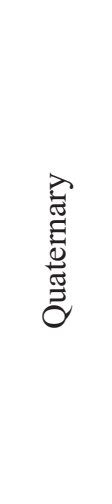 & & 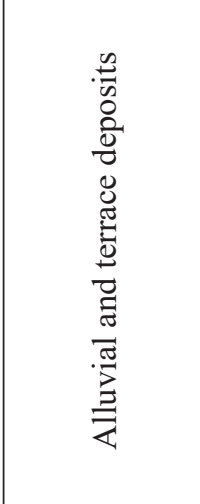 & 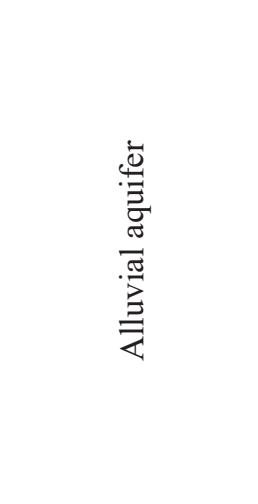 & $\begin{array}{l}0 \\
n \\
n^{\prime} \\
\tilde{n}\end{array}$ & 志 & $\begin{array}{l}\text { Most recent sediments in place. Quaternary deposits in } \\
\text { Osage County are essentially composed of alluvium } \\
\text { and terrace deposits of sand, silt, and clay (Heran and } \\
\text { others, 2003; Mashburn and others, 2003). Some gravel } \\
\text { deposits are found locally. Minor volcanic ash is pres- } \\
\text { ent in terrace deposits. The alluvial aquifer is uncon- } \\
\text { fined and uncemented. The alluvium was deposited by } \\
\text { the Arkansas River and tributary streams. The terrace } \\
\text { deposits were believed to have been deposited by the } \\
\text { Arkansas River when it was flowing at a higher level } \\
\text { and has been reworked by eolian processes (Mash- } \\
\text { burn and others, 2003). }\end{array}$ & 1 & 9.8 & 167.5 & 704.2 \\
\hline \multirow{2}{*}{ 胥 } & 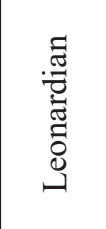 & 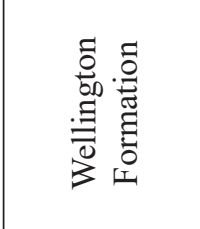 & 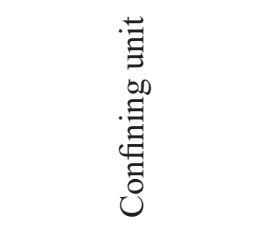 & 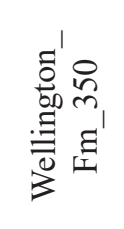 & 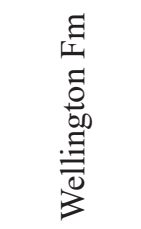 & $\begin{array}{l}\text { The Wellington Formation is primarily red-brown shale } \\
\text { grading into fine-grained sandstone and mudstone. } \\
\text { Orange-brown fine-grained sandstone. Mudstone } \\
\text { conglomerate and chert conglomerate found locally } \\
\text { (Brown, 1967). }\end{array}$ & & & & \\
\hline & 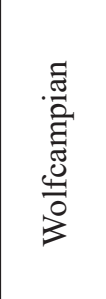 & 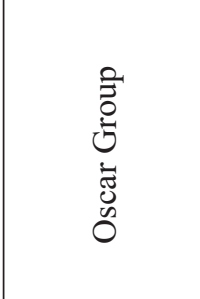 & 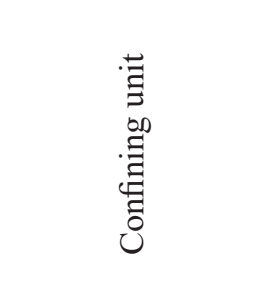 & 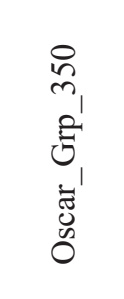 & 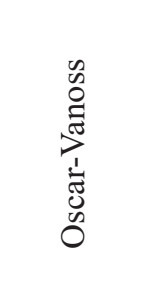 & $\begin{array}{l}\text { Alternating limestone and shale with shale being pre- } \\
\text { dominant (Heran and others, 2003). To a lesser extent, } \\
\text { sandstone, conglomerate, and coal deposits are found } \\
\text { locally. Vanoss Group is primarily fine-grained arkosic } \\
\text { sandstone (Bingham and Bergman, 1980). All strata are } \\
\text { arkosic, most of the sandstones are so much arkosic } \\
\text { that they might be taken for granite. }\end{array}$ & 2 & 9.8 & 644.2 & $1,750.9$ \\
\hline
\end{tabular}


Table 2. Stratigraphic column showing geologic ages; geologic units; hydrostratigraphic units; three-dimensional geology model layer names; Osage Nation Integrated Hydrologic Model (ONIHM) layer name, number; and minimum, mean, and maximum thickness._Continued

[3D, three dimensional; ONIHM, Osage Nation Integrated Hydrologic Model; min, minimum; max, maximum; --, no data]

\begin{tabular}{|c|c|c|c|c|c|c|c|c|c|c|}
\hline \multirow{2}{*}{ System } & \multirow{2}{*}{ Series } & \multirow{2}{*}{ Geologic unit ${ }^{1}$} & \multirow{2}{*}{$\begin{array}{c}\text { Hydrostratigraphic } \\
\text { unit }\end{array}$} & \multirow{2}{*}{$\begin{array}{c}\text { 3D } \\
\text { geology } \\
\text { model } \\
\text { layer } \\
\text { name }^{1}\end{array}$} & \multirow{2}{*}{$\begin{array}{l}\text { ONIHM } \\
\text { layer unit } \\
\text { name }\end{array}$} & \multirow{2}{*}{ Description } & \multirow{2}{*}{$\begin{array}{l}\text { ONIHM } \\
\text { layer } \\
\text { number }\end{array}$} & \multicolumn{3}{|c|}{$\begin{array}{c}\text { ONIHM layer thickness, } \\
\text { in feet }\end{array}$} \\
\hline & & & & & & & & Min & Mean & Max \\
\hline . & 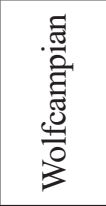 & \multirow[t]{2}{*}{ 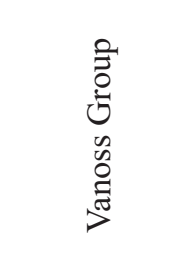 } & \multirow[t]{2}{*}{ 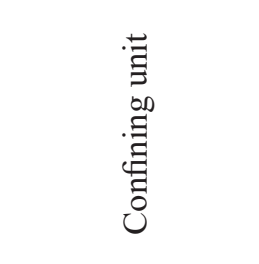 } & \multirow{2}{*}{ 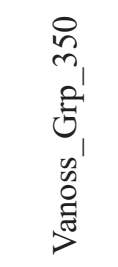 } & \multirow[t]{2}{*}{ 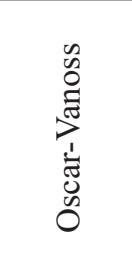 } & \multirow[t]{2}{*}{$\begin{array}{l}\text { The Oscar Group is predominantly shale with many lay- } \\
\text { ers of limestones with fine-grained arkosic sandstones } \\
\text { that are thicker and more numerous. }\end{array}$} & \multirow{3}{*}{2} & \multirow{3}{*}{9.8} & \multirow{3}{*}{644.2} & \multirow{3}{*}{$1,750.9$} \\
\hline \multirow{5}{*}{ 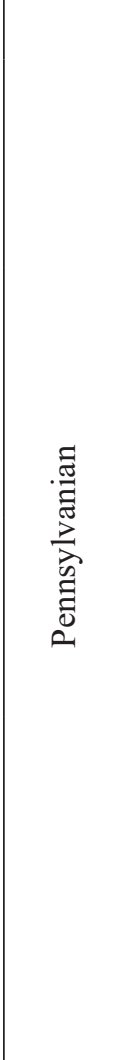 } & \multirow{5}{*}{ 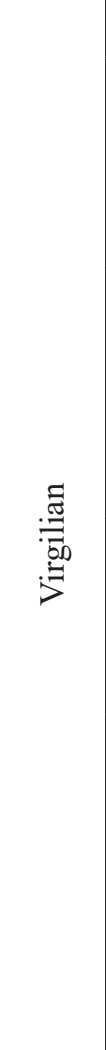 } & & & & & & & & & \\
\hline & & \multirow{4}{*}{ 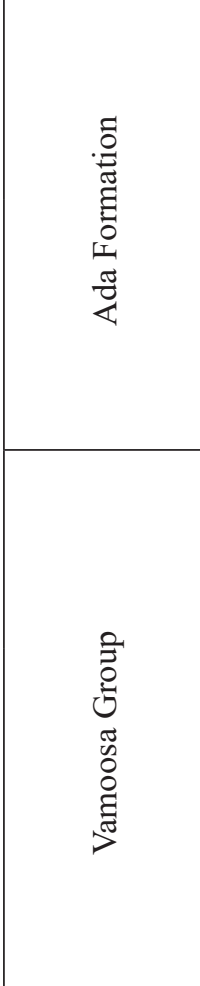 } & \multirow{4}{*}{ 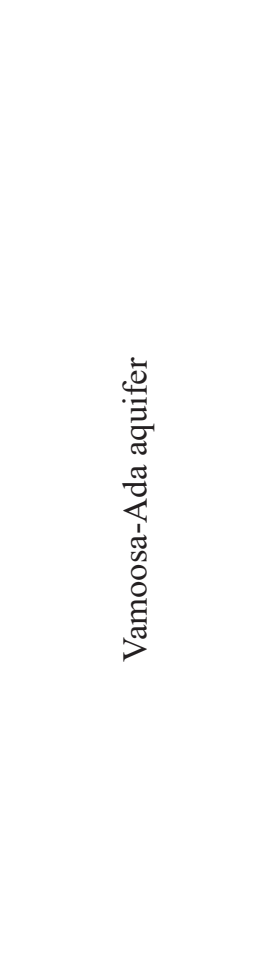 } & $\begin{array}{l}e_{3} \\
\frac{\pi}{2}\end{array}$ & 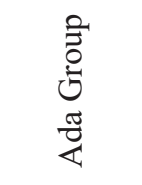 & Auburn Shale, Bern Limestone, and Scranton Shale & & & & \\
\hline & & & & 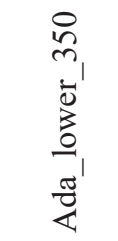 & \begin{tabular}{l}
$\frac{\pi}{0}$ \\
\multirow{4}{1}{} \\
$\dot{0}$ \\
3 \\
0 \\
1
\end{tabular} & \multirow{2}{*}{$\begin{array}{l}\text { Primarily shale, with many limestone layers that are } \\
\text { much thinner. Sandstone is also present in a consider- } \\
\text { able amount. To a lesser extent, some conglomerates } \\
\text { are found locally (Naff, 1981). The Ada Formation con- } \\
\text { sists of interbedded limestone and shale units. Clastic } \\
\text { material decreases near contact with the Vamoosa } \\
\text { Group which consists of alternating layers of shale and } \\
\text { fine- to coarse-grained sandstone with some limestone } \\
\text { (Tanner, 1956). }\end{array}$} & 3 & 9.8 & 132.9 & 323.9 \\
\hline & & & & 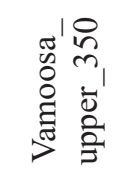 & 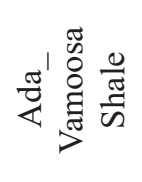 & & & & & \\
\hline & & & & 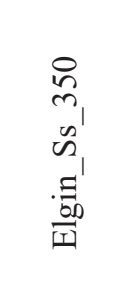 & $\frac{\Xi 00}{\square}$ & $\begin{array}{l}\text { Yellowish to gray, very fine- to fine-grained, friable, } \\
\text { subangular to subrounded, well sorted, thin- to thick- } \\
\text { bedded quartzose sandstone. Common ripple marks } \\
\text { and crossbeds; interbedded siltstones, shales, and } \\
\text { sandstones that grade vertically and horizontally. Bar } \\
\text { fingers and fossil deposits, consistent with a shallow } \\
\text { marine or deltaic deposit (Brown, 1967). }\end{array}$ & 4 & 9.8 & 59.3 & 225.8 \\
\hline
\end{tabular}


Table 2. Stratigraphic column showing geologic ages; geologic units; hydrostratigraphic units; three-dimensional geology model layer names; Osage Nation Integrated Hydrologic Model (ONIHM) layer name, number; and minimum, mean, and maximum thickness.-Continued

[3D, three dimensional; ONIHM, Osage Nation Integrated Hydrologic Model; min, minimum; max, maximum; --, no data]

\begin{tabular}{|c|c|c|c|c|c|c|c|c|c|c|}
\hline \multirow{2}{*}{ System } & \multirow{2}{*}{ Series } & \multirow{2}{*}{ Geologic unit ${ }^{1}$} & \multirow{2}{*}{$\begin{array}{l}\text { Hydrostratigraphic } \\
\text { unit }\end{array}$} & \multirow{2}{*}{$\begin{array}{l}\text { 3D } \\
\text { geology } \\
\text { model } \\
\text { layer } \\
\text { name }^{1}\end{array}$} & \multirow{2}{*}{$\begin{array}{l}\text { ONIHM } \\
\text { layer unit } \\
\text { name }\end{array}$} & \multirow{2}{*}{ Description } & \multirow{2}{*}{$\begin{array}{c}\text { ONIHM } \\
\text { layer } \\
\text { number }\end{array}$} & \multicolumn{3}{|c|}{$\begin{array}{l}\text { ONIHM layer thickness, } \\
\text { in feet }\end{array}$} \\
\hline & & & & & & & & Min & Mean & Max \\
\hline \multirow{3}{*}{ 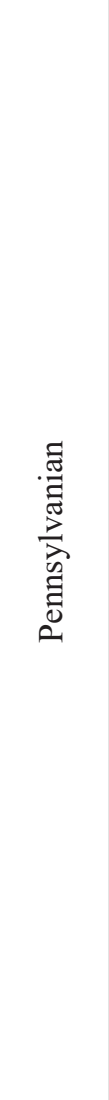 } & \multirow{3}{*}{ 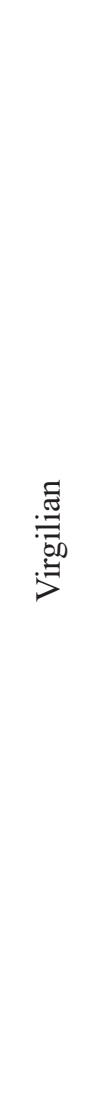 } & \multirow{3}{*}{ 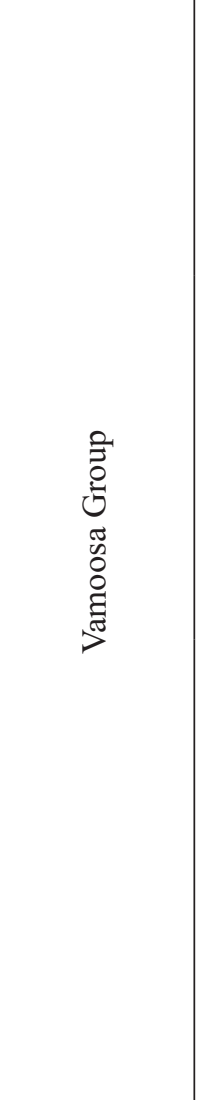 } & \multirow{3}{*}{ 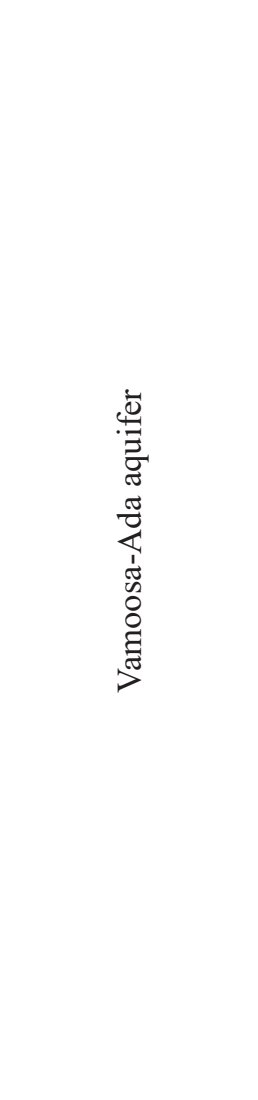 } & 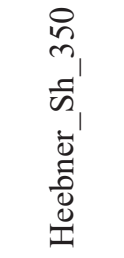 & 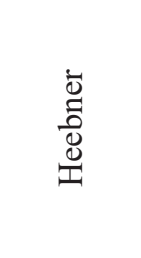 & $\begin{array}{l}\text { The Heebner Shale Bed is predominantly plant rich shale } \\
\text { that is widespread and coarsening upward (Yang and } \\
\text { others, 2003) toward siltstone and sandstone and is } \\
\text { consistent with predeltaic and deltaic environment } \\
\text { deposits. }\end{array}$ & \multirow[b]{2}{*}{5} & \multirow[b]{2}{*}{9.8} & \multirow[b]{2}{*}{96.4} & \multirow[b]{2}{*}{251.8} \\
\hline & & & & 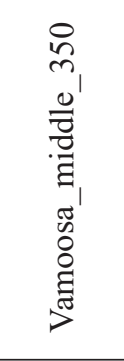 & 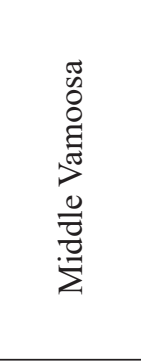 & $\begin{array}{l}\text { The middle part of the Vamoosa is composed of dark } \\
\text { shale that includes } 260 \text { feet of chert conglomerates; } \\
\text { massive, coarse, red and brown sandstones; and red } \\
\text { shales. Chert fragmentation observed locally makes } \\
\text { angular conglomerates (Heran and others, 2003). }\end{array}$ & & & & \\
\hline & & & & 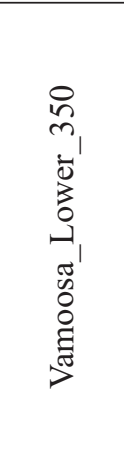 & 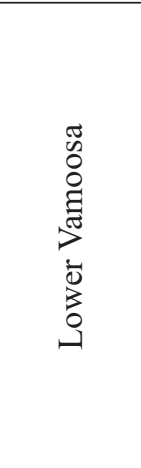 & $\begin{array}{l}\text { Unconformably overlaying the Hogshooter Formation, the } \\
\text { lower part of the Vamoosa Group is composed of plant } \\
\text { bearing sandstone, limestone, and shale. Cheshewalla } \\
\text { Sandstone, the basal member, is 7-20 feet thick, thin } \\
\text { bedded to massive, crossbedded, fine- to very fine- } \\
\text { grained sandstone or siltstone. Above the sandstone } \\
\text { is the fossiliferous Bowring Limestone Member that } \\
\text { includes at various locations some brown sandstone. } \\
\text { Red shale and clay pebble conglomerate. Suggested } \\
\text { deltaic and lagoonal depositional environments. Thick- } \\
\text { ness varies from } 250 \text { to } 310 \text { feet (Tanner, 1956). }\end{array}$ & 6 & 9.8 & 160.5 & 463.0 \\
\hline
\end{tabular}


Table 2. Stratigraphic column showing geologic ages; geologic units; hydrostratigraphic units; three-dimensional geology model layer names; Osage Nation Integrated Hydrologic Model (ONIHM) layer name, number; and minimum, mean, and maximum thickness._-Continued

[3D, three dimensional; ONIHM, Osage Nation Integrated Hydrologic Model; min, minimum; max, maximum; --, no data]

\begin{tabular}{|c|c|c|c|c|c|c|c|c|c|c|}
\hline \multirow{2}{*}{ System } & \multirow{2}{*}{ Series } & \multirow{2}{*}{ Geologic unit ${ }^{1}$} & \multirow{2}{*}{$\begin{array}{l}\text { Hydrostratigraphic } \\
\text { unit }\end{array}$} & \multirow{2}{*}{$\begin{array}{c}\text { 3D } \\
\text { geology } \\
\text { model } \\
\text { layer } \\
\text { name }^{1}\end{array}$} & \multirow{2}{*}{$\begin{array}{l}\text { ONIHM } \\
\text { layer unit } \\
\text { name }\end{array}$} & \multirow{2}{*}{ Description } & \multirow{2}{*}{$\begin{array}{l}\text { ONIHM } \\
\text { layer } \\
\text { number }\end{array}$} & \multicolumn{3}{|c|}{$\begin{array}{l}\text { ONIHM layer thickness, } \\
\text { in feet }\end{array}$} \\
\hline & & & & & & & & Min & Mean & Max \\
\hline \multirow{4}{*}{ 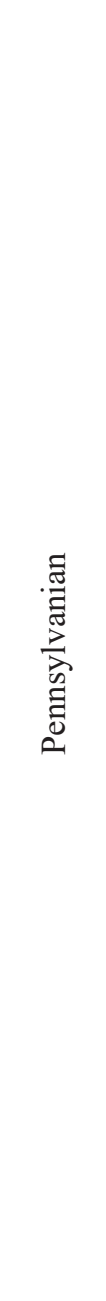 } & \multirow{4}{*}{ 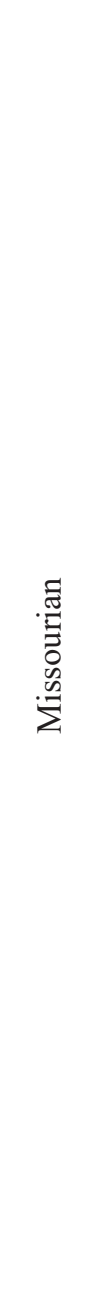 } & \multirow[t]{3}{*}{$\begin{array}{l}0 \\
0 \\
0 \\
0 \\
\frac{\pi}{0} \\
\frac{\pi}{0} \\
\frac{\pi}{0}\end{array}$} & \multirow{3}{*}{ 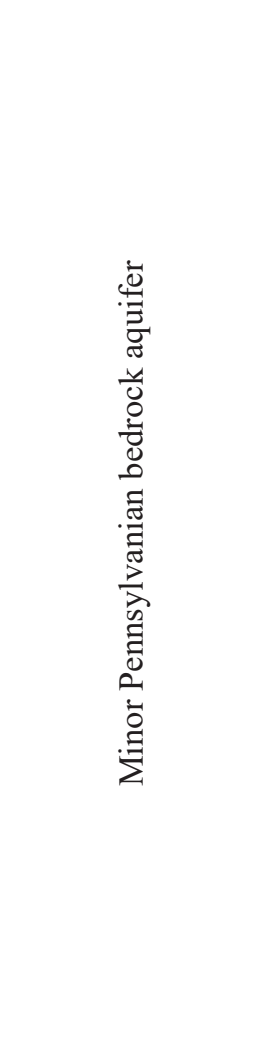 } & 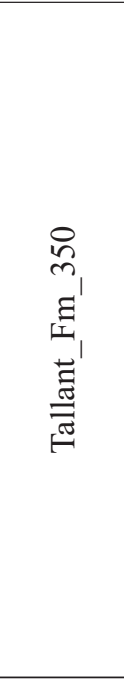 & 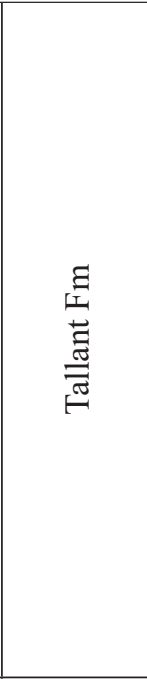 & $\begin{array}{l}\text { Two continuous layers of gray shale alternate with } \\
\text { Revard sandstone and Bigheart Sandstone Mem- } \\
\text { ber. Local deposits of red shale are found within the } \\
\text { continuous layers of gray shale and sandstone. Shale } \\
\text { deposits are consistent with lagoonal environment, } \\
\text { whereas sandstone is more consistent with a con- } \\
\text { tinental depositional environment. Sandstone has a } \\
\text { fuzzy boundary, making member thicknesses difficult to } \\
\text { estimate. Low angle crossbeds, ripple marks, fossilized } \\
\text { shells, as well as thin layers of limestone (one-quarter } \\
\text { of an inch to } 2 \text { inches thick) and limestone concretions } \\
\text { (as much as } 3 \text { feet, } 3 \text { inches in diameter), all present at } \\
\text { diverse horizons. Plant debris found in the sandstone } \\
\text { is generally striking north-northeast. Tallant Forma- } \\
\text { tion thickness varies from } 100 \text { to } 250 \text { feet. Depositional } \\
\text { environment is partly deltaic (Tanner, 1956). }\end{array}$ & \multirow[t]{2}{*}{7} & \multirow[t]{2}{*}{9.8} & \multirow[t]{2}{*}{318.9} & \multirow[t]{2}{*}{669.8} \\
\hline & & & & 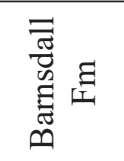 & 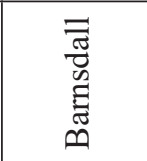 & $\begin{array}{l}\text { Shale, siltstone, sandstone, and thin limestone. Uncon- } \\
\text { formably overlies the Wann Formation. }\end{array}$ & & & & \\
\hline & & & & 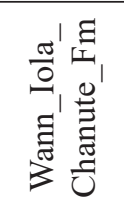 & 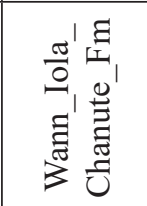 & $\begin{array}{l}\text { Shale with some thin sandstone and limestone; thick- } \\
\text { bedded coarse-grained sandstone near base (Marcher } \\
\text { and Bingham, 1971). }\end{array}$ & \multirow[b]{2}{*}{8} & \multirow[b]{2}{*}{9.8} & \multirow[b]{2}{*}{302.4} & \multirow[b]{2}{*}{485.7} \\
\hline & & 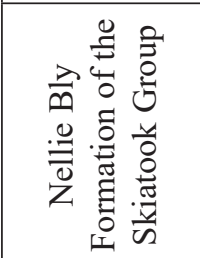 & $\begin{array}{l}\cdot \Xi \\
\Xi \\
00 \\
. \Xi \\
\vdots \\
0 \\
0\end{array}$ & 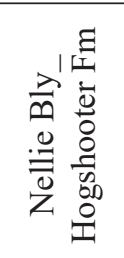 & 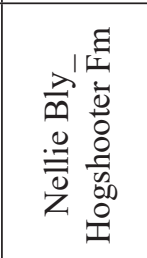 & $\begin{array}{l}\text { Shale and thin-bedded sandstone; limestone with some } \\
\text { shale (Marcher and Bingham, 1971). }\end{array}$ & & & & \\
\hline
\end{tabular}


Table 2. Stratigraphic column showing geologic ages; geologic units; hydrostratigraphic units; three-dimensional geology model layer names; Osage Nation Integrated Hydrologic Model (ONIHM) layer name, number; and minimum, mean, and maximum thickness.-Continued

[3D, three dimensional; ONIHM, Osage Nation Integrated Hydrologic Model; min, minimum; max, maximum; --, no data]

\begin{tabular}{|c|c|c|c|c|c|c|c|c|c|c|}
\hline \multirow{2}{*}{ System } & \multirow{2}{*}{ Series } & \multirow{2}{*}{ Geologic unit ${ }^{1}$} & \multirow{2}{*}{$\begin{array}{l}\text { Hydrostratigraphic } \\
\text { unit }\end{array}$} & \multirow{2}{*}{$\begin{array}{c}\text { 3D } \\
\text { geology } \\
\text { model } \\
\text { layer } \\
\text { name }^{1}\end{array}$} & \multirow{2}{*}{$\begin{array}{l}\text { ONIHM } \\
\text { layer unit } \\
\text { name }\end{array}$} & \multirow{2}{*}{ Description } & \multirow{2}{*}{$\begin{array}{l}\text { ONIHM } \\
\text { layer } \\
\text { number }\end{array}$} & \multicolumn{3}{|c|}{$\begin{array}{l}\text { ONIHM layer thickness, } \\
\text { in feet }\end{array}$} \\
\hline & & & & & & & & Min & Mean & Max \\
\hline \multirow{2}{*}{ 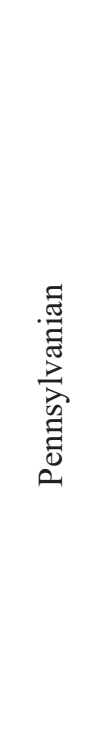 } & 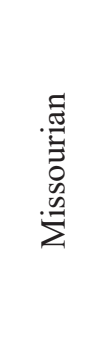 & 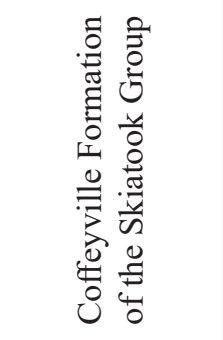 & \multirow{2}{*}{ 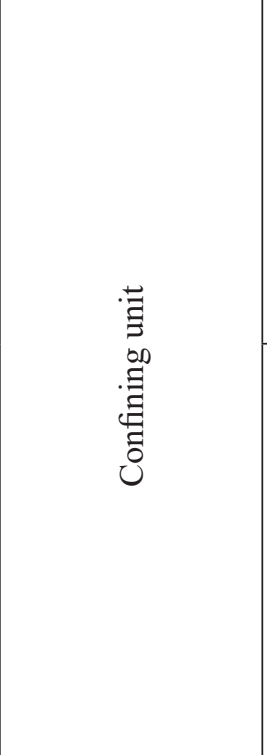 } & 尝 & 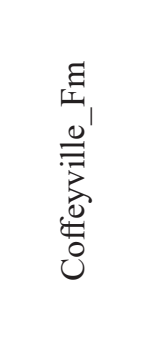 & $\begin{array}{l}\text { Black shale interbedded with sandstone (Marcher and } \\
\text { Bingham, 1971). }\end{array}$ & 8 & 9.8 & 302.4 & 485.7 \\
\hline & 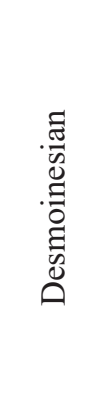 & 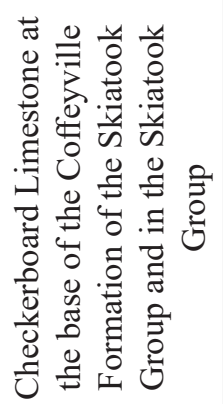 & & 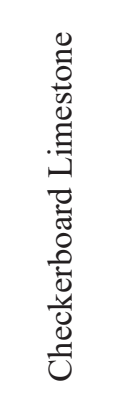 & 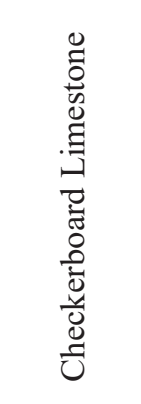 & $\begin{array}{l}\text { Limestone with some shale (Marcher and Bingham, } \\
\text { 1971). }\end{array}$ & $\begin{array}{l}\text { Coffeyville/ } \\
\text { Checker- } \\
\text { board } \\
\text { contact } \\
\text { is base of } \\
\text { model }\end{array}$ & -- & -- & -- \\
\hline
\end{tabular}

${ }^{1}$ Modified from Hudson and others, 2016. 


\section{Appendix 1. Supplemental Calibration Results}

Summary tables and charts for the calibration results are included in the "Integrated Hydrologic Model Calibration Results" section of the report. Plots of measured versus simulated streamflows at each streamgage for streamflows with nonzero weighted values used during the calibration are presented hereinafter (figs. 1.1-1.15) for readers interested in more detailed calibration results of the Osage Nation Integrated Hydrologic Model. Additionally, two plots of mean annual and mean monthly landscape water budgets for the 1950-2014 period are presented as depths, in inches (figs. 1.16-1.17). 


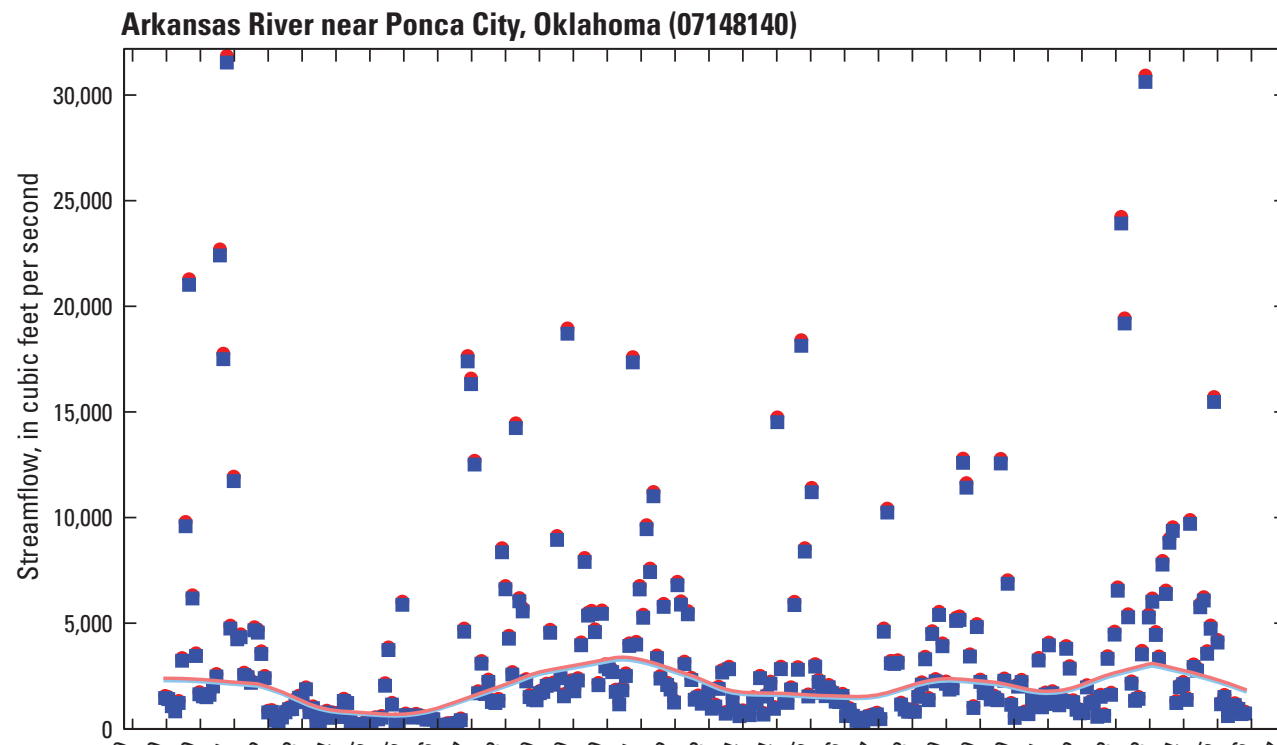

EXPLANATION

Lowess

- Simulated

- Measured

Streamflow

- Simulated

- Measured

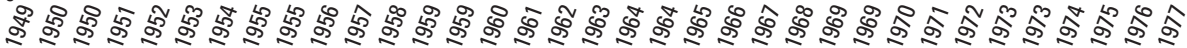

Year

Figure 1.1. Measured and simulated streamflows for the Arkansas River near Ponca City, Oklahoma, streamgage (07148140).

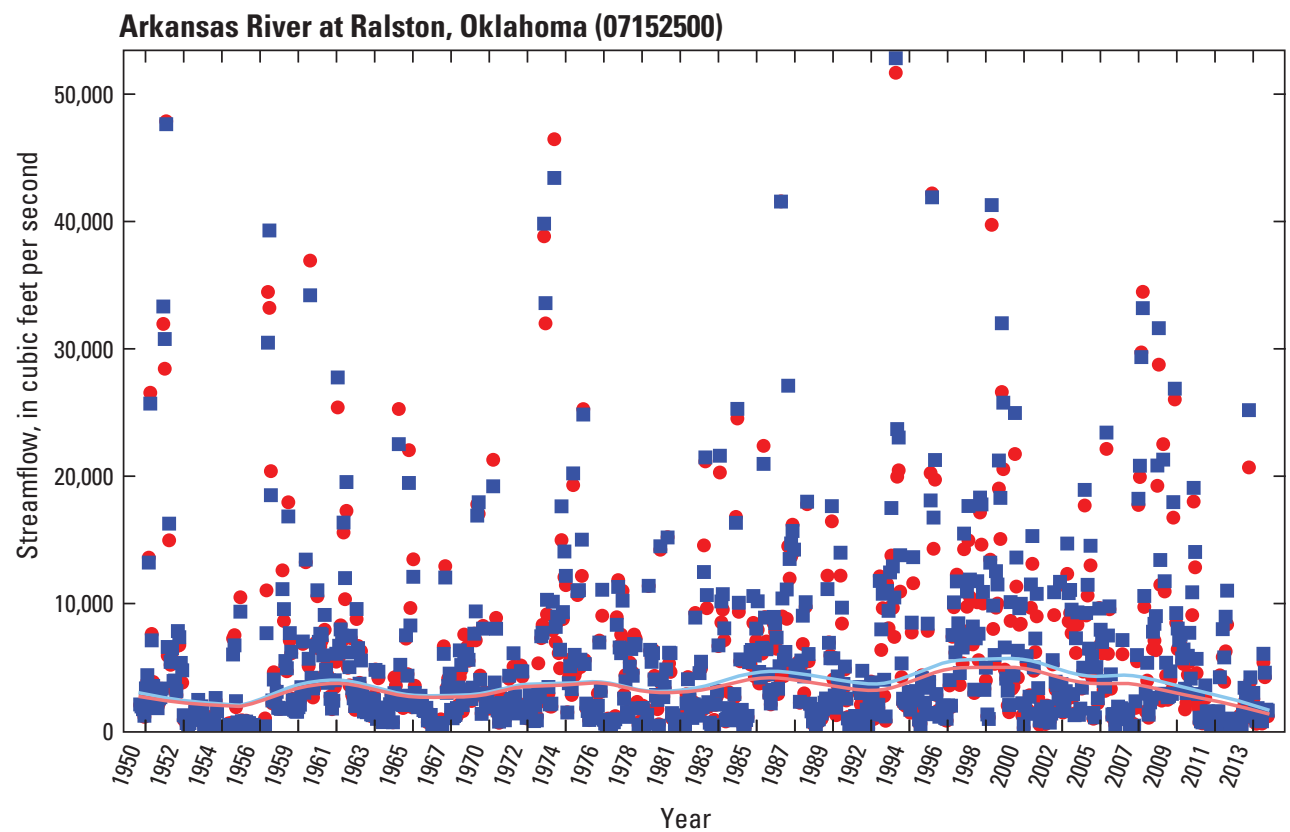

EXPLANATION

Lowess

- Simulated

- Measured

Streamflow

- Simulated

- Measured

Figure 1.2. Measured and simulated streamflows for the Arkansas River at Ralston, Oklahoma, streamgage (07152500). 


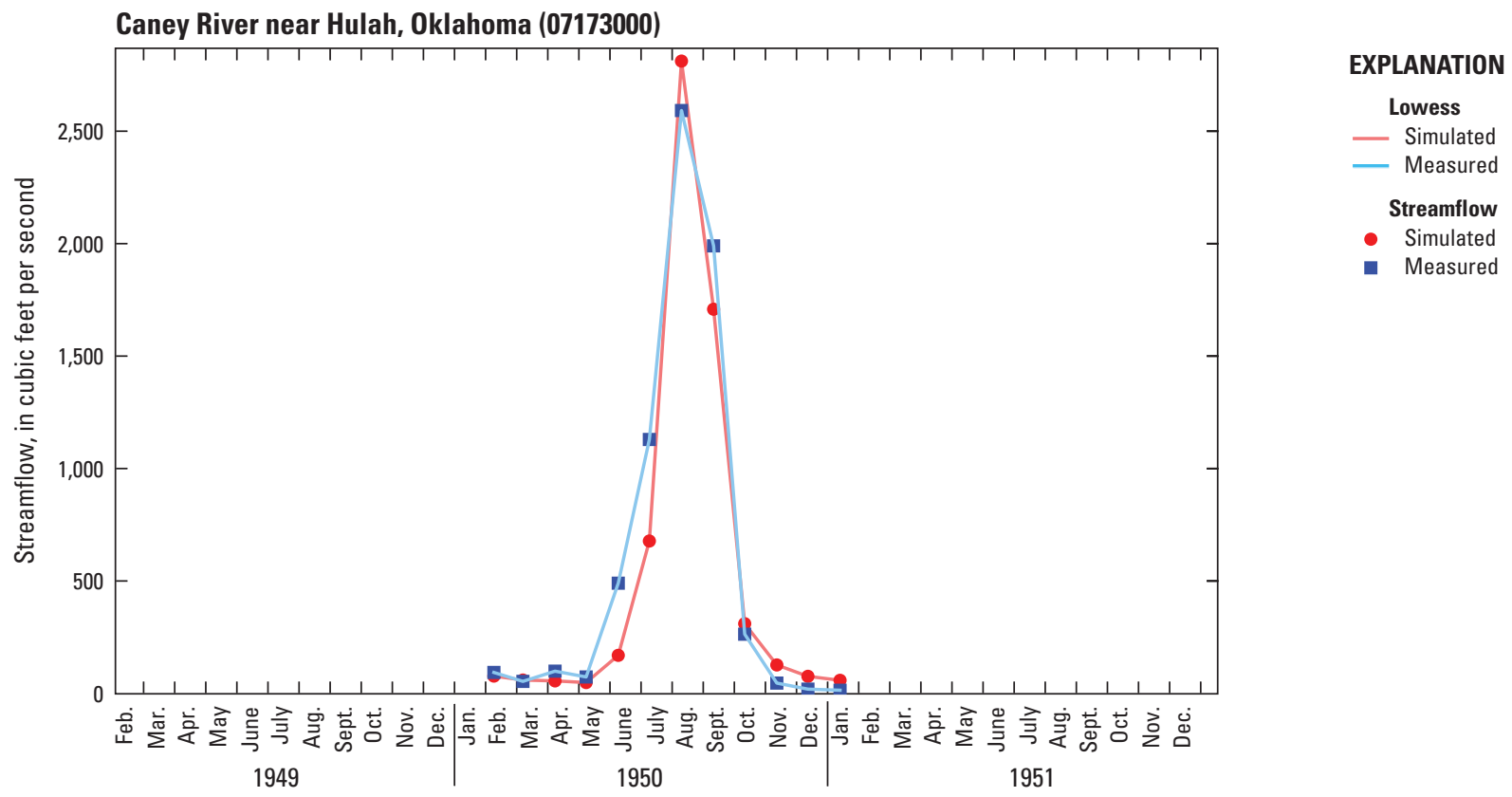

Figure 1.3. Measured and simulated streamflows for the Caney River near Hulah, Oklahoma, streamgage (07173000).

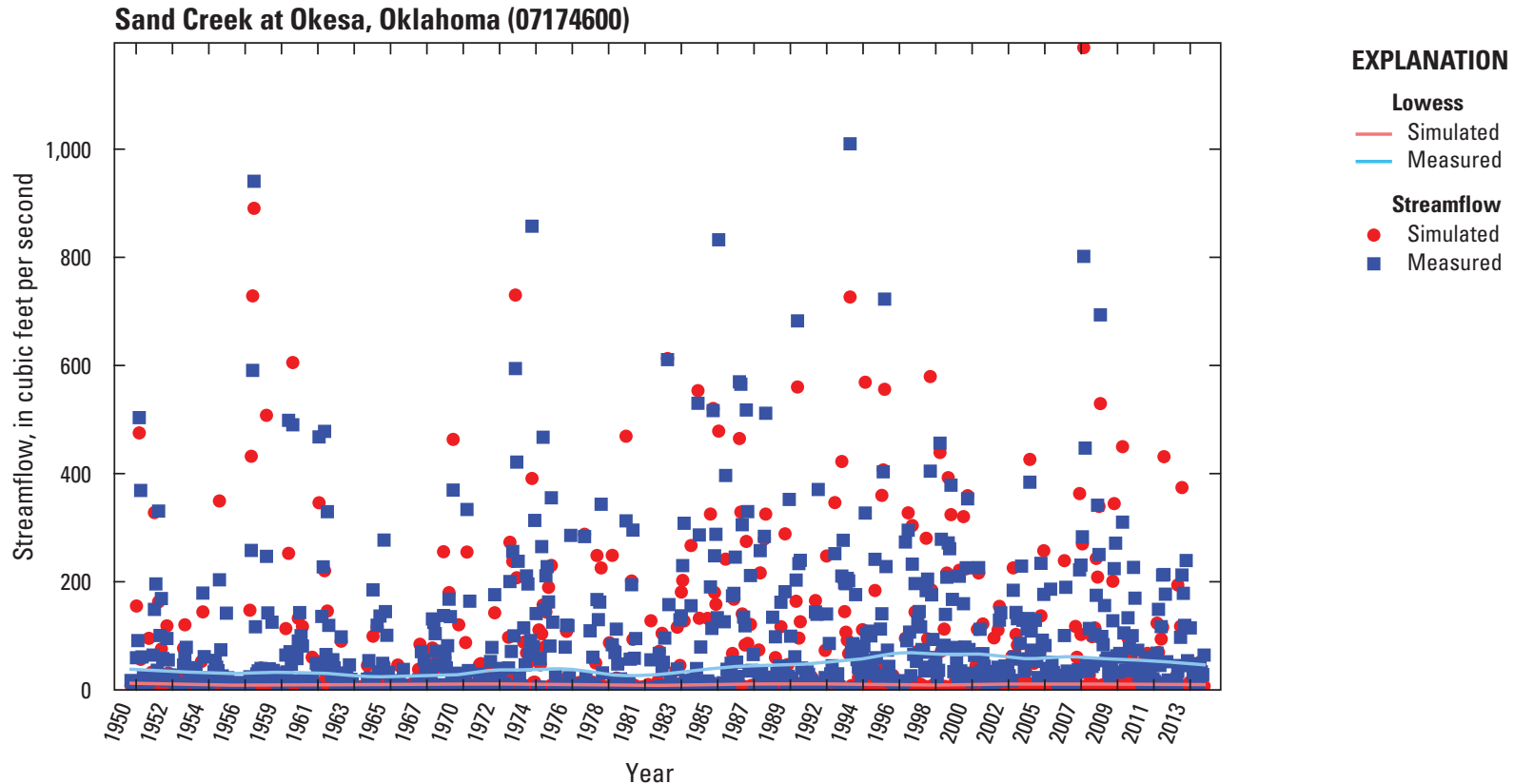

Figure 1.4. Measured and simulated streamflows for the Sand Creek at Okesa, Oklahoma, streamgage (07174600). 


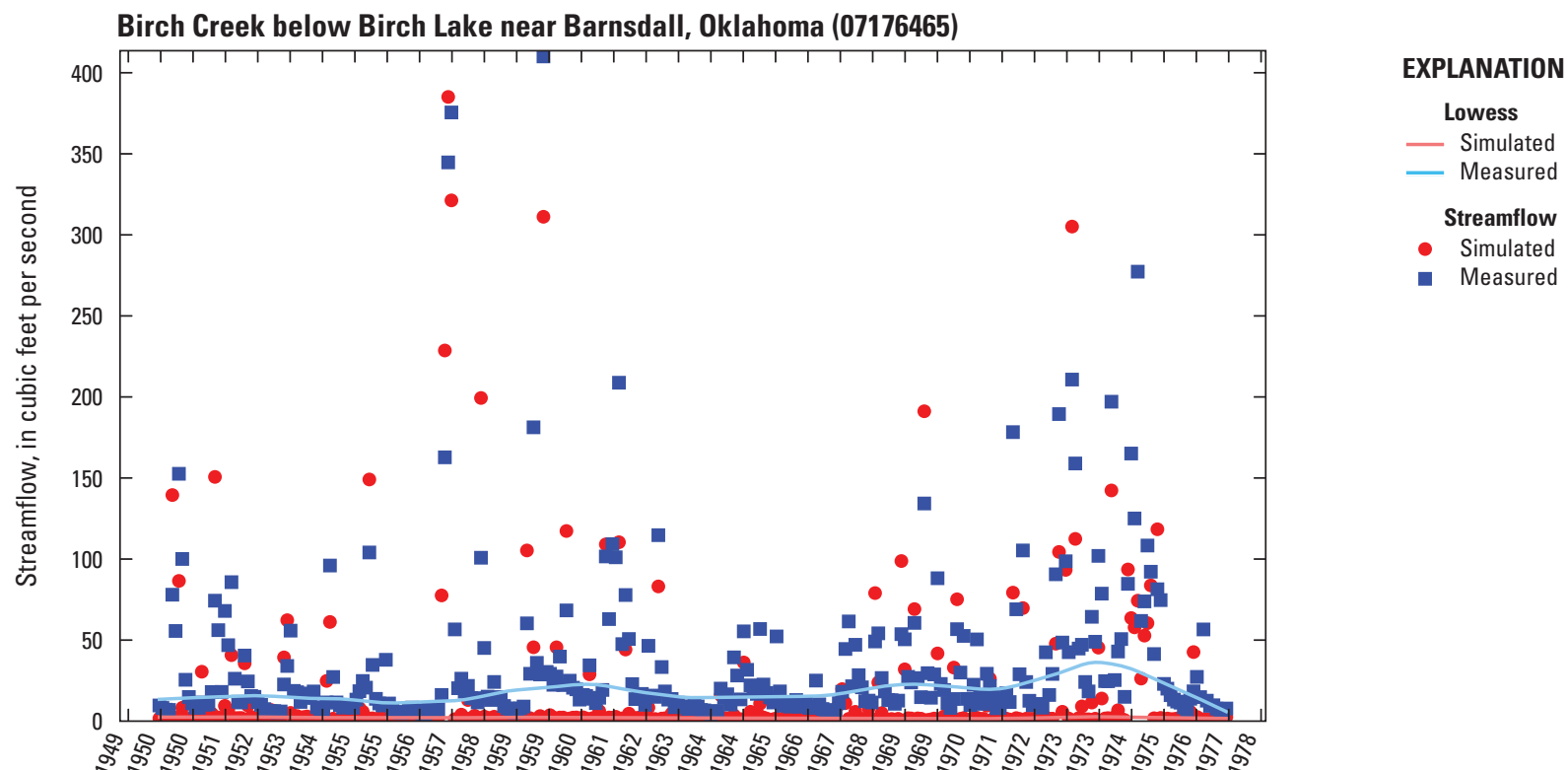

Year

Figure 1.5. Measured and simulated streamflows for the Birch Creek below Birch Lake near Barnsdall, Oklahoma, streamgage (07176465).

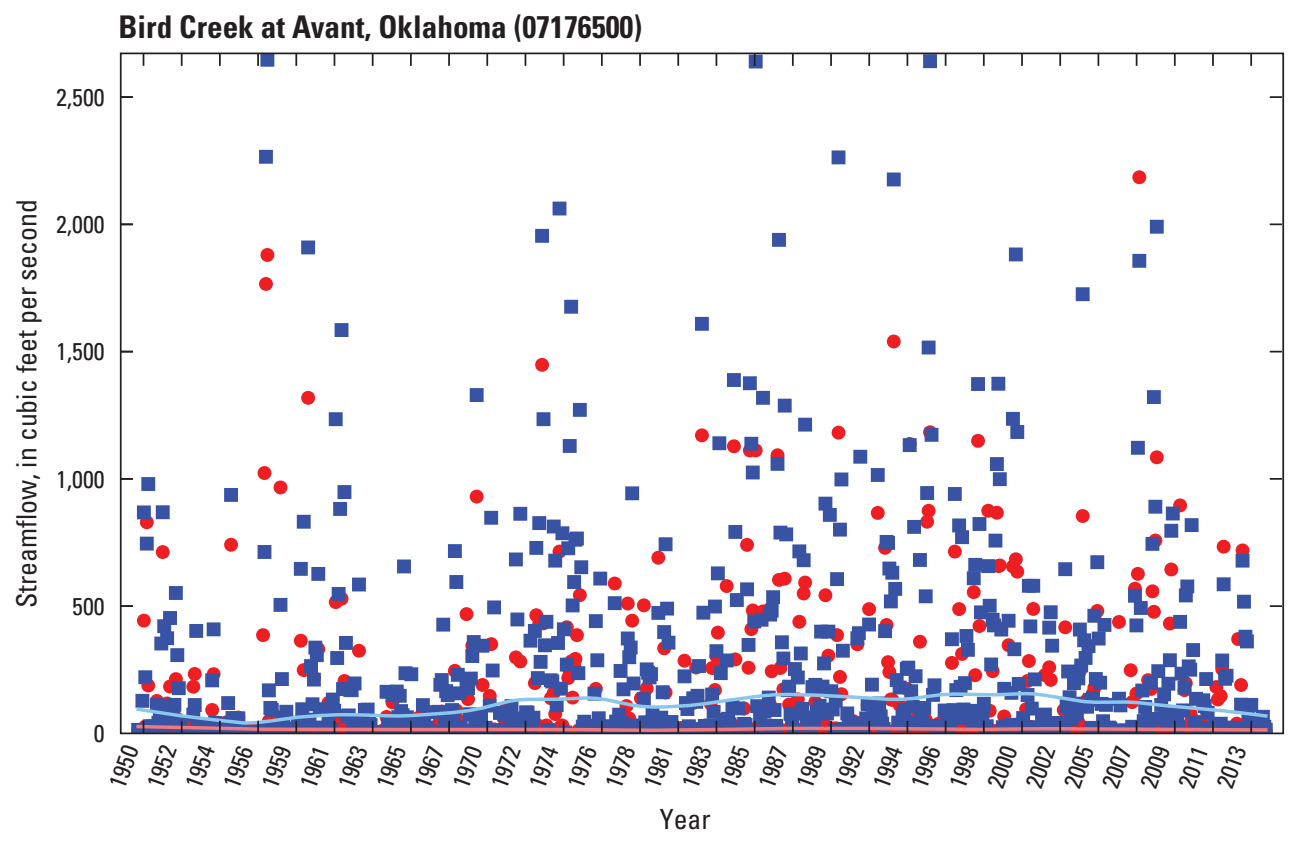

EXPLANATION

Lowess

- Simulated

- Measured

Streamflow

- Simulated

- Measured

Figure 1.6. Measured and simulated streamflows for the Bird Creek at Avant, Oklahoma, streamgage (07176500). 


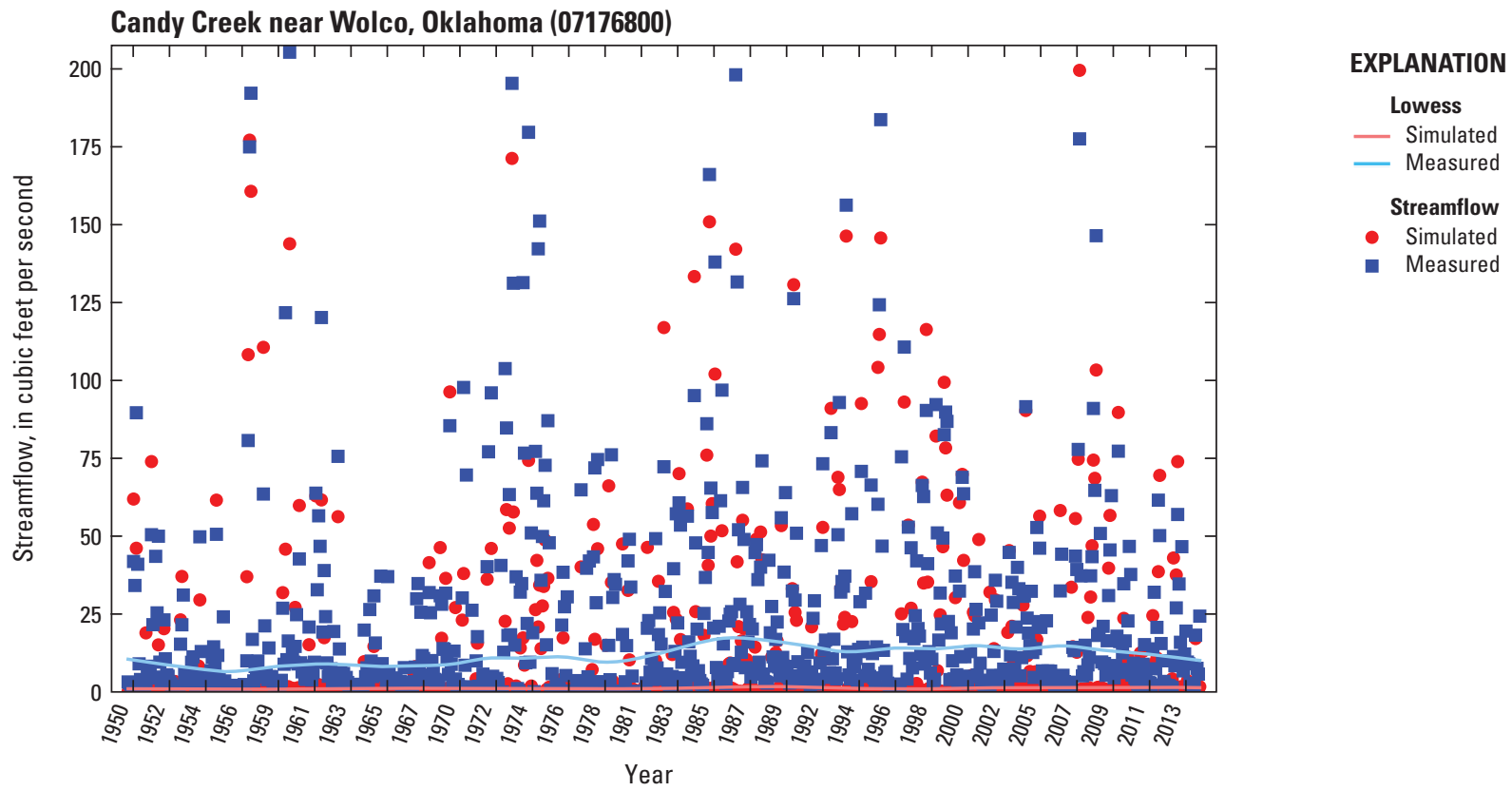

Figure 1.7. Measured and simulated streamflows for the Candy Creek near Wolco, Oklahoma, streamgage (07176800).

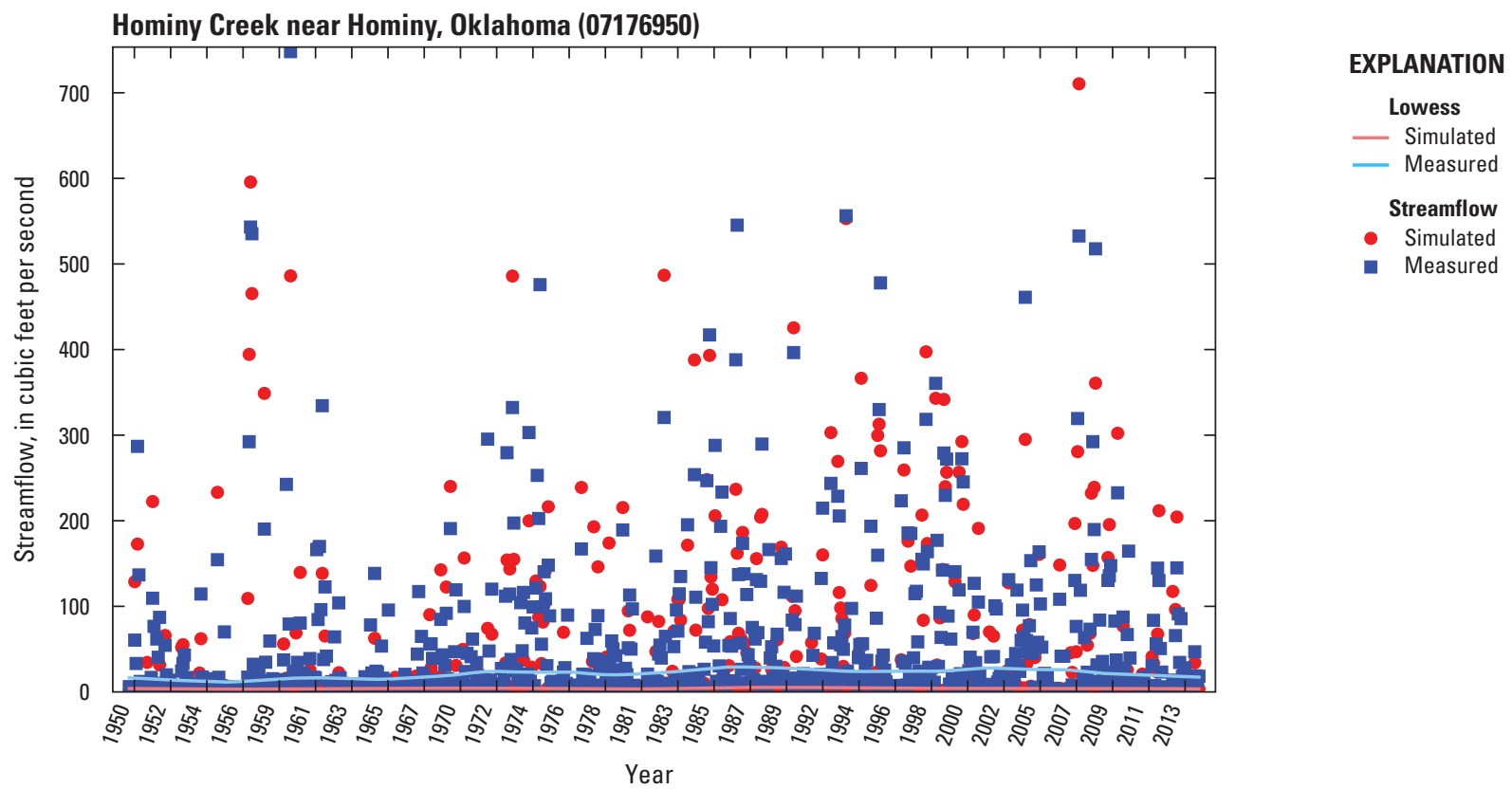

Figure 1.8. Measured and simulated streamflows for the Hominy Creek near Hominy, Oklahoma, streamgage (07176950). 


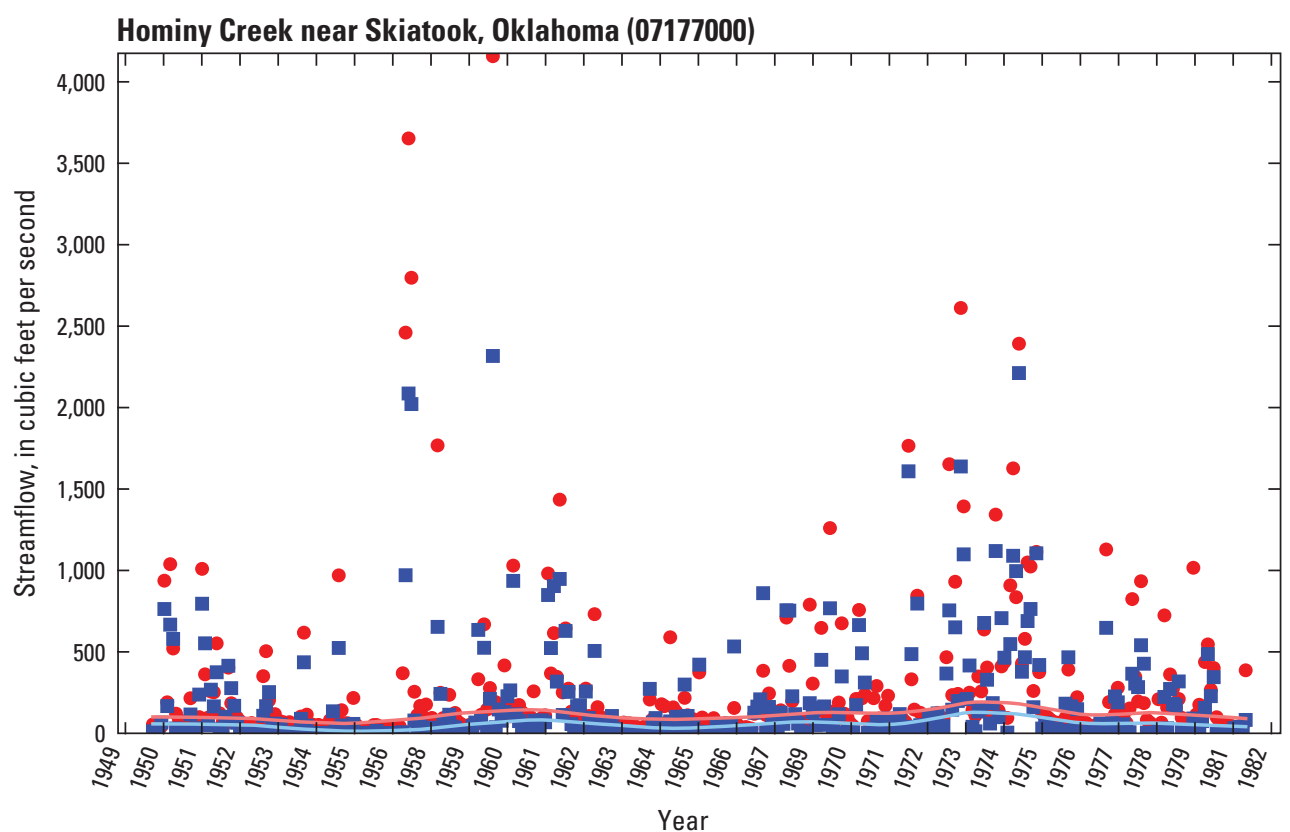

EXPLANATION

Lowess

- Simulated

- Measured

Streamflow

- Simulated

- Measured

Figure 1.9. Measured and simulated streamflows for the Hominy Creek at Skiatook, Oklahoma, streamgage (07177000).

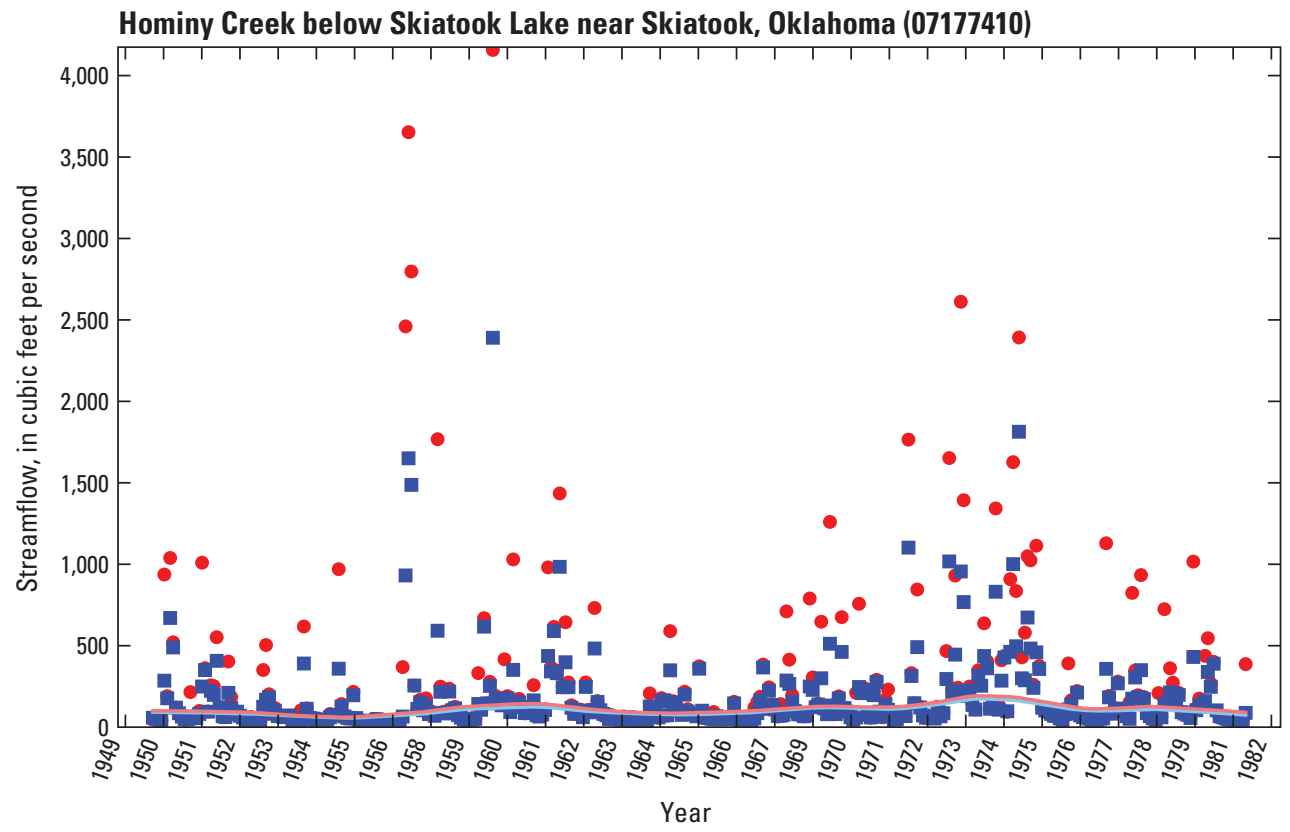

EXPLANATION

Lowess

- Simulated

— Measured

Streamflow

- Simulated

- Measured

Figure 1.10. Measured and simulated streamflows for the Hominy Creek below Skiatook Lake near Skiatook, Oklahoma, streamgage (07177410). 


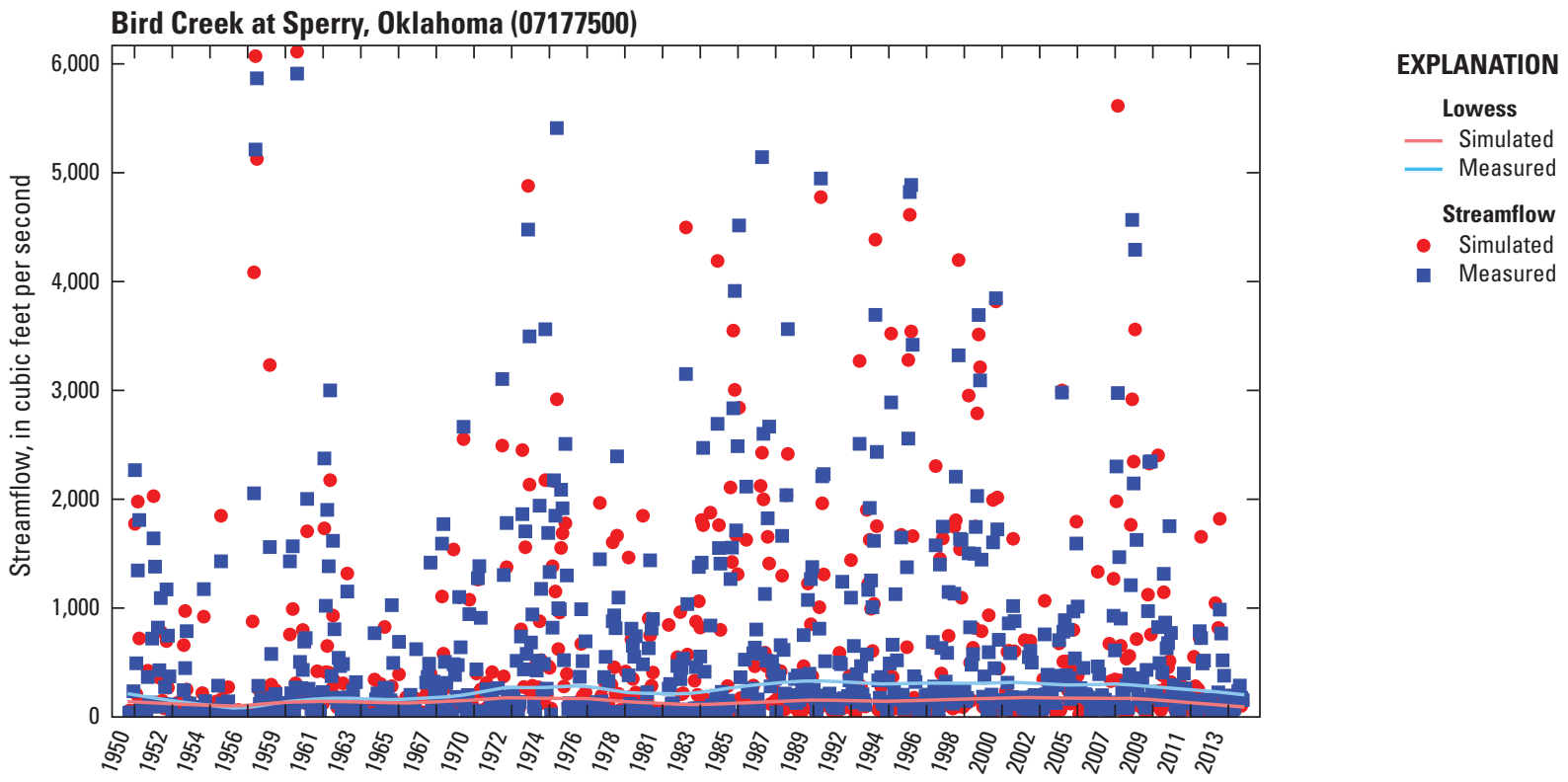

Year

Figure 1.11. Measured and simulated streamflows for the Bird Creek at Sperry, Oklahoma, streamgage (07177500).

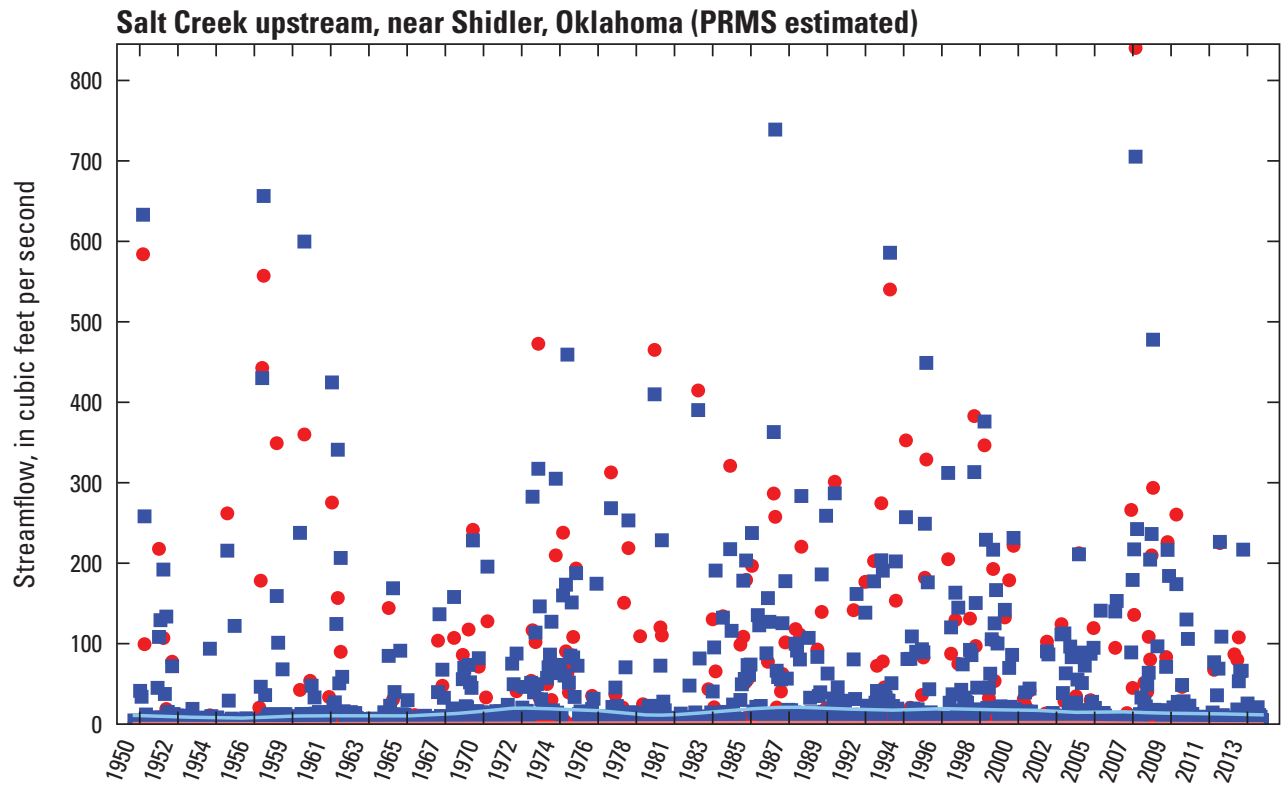

EXPLANATION

[PRMS, Precipitation Runoff

Modeling System]

Lowess

— Simulated

- Measured

Streamflow

- Simulated

- Measured

Figure 1.12. Measured and simulated streamflows for Salt Creek upstream, near Shidler, Oklahoma (Precipitation Runoff Modeling System estimated). 


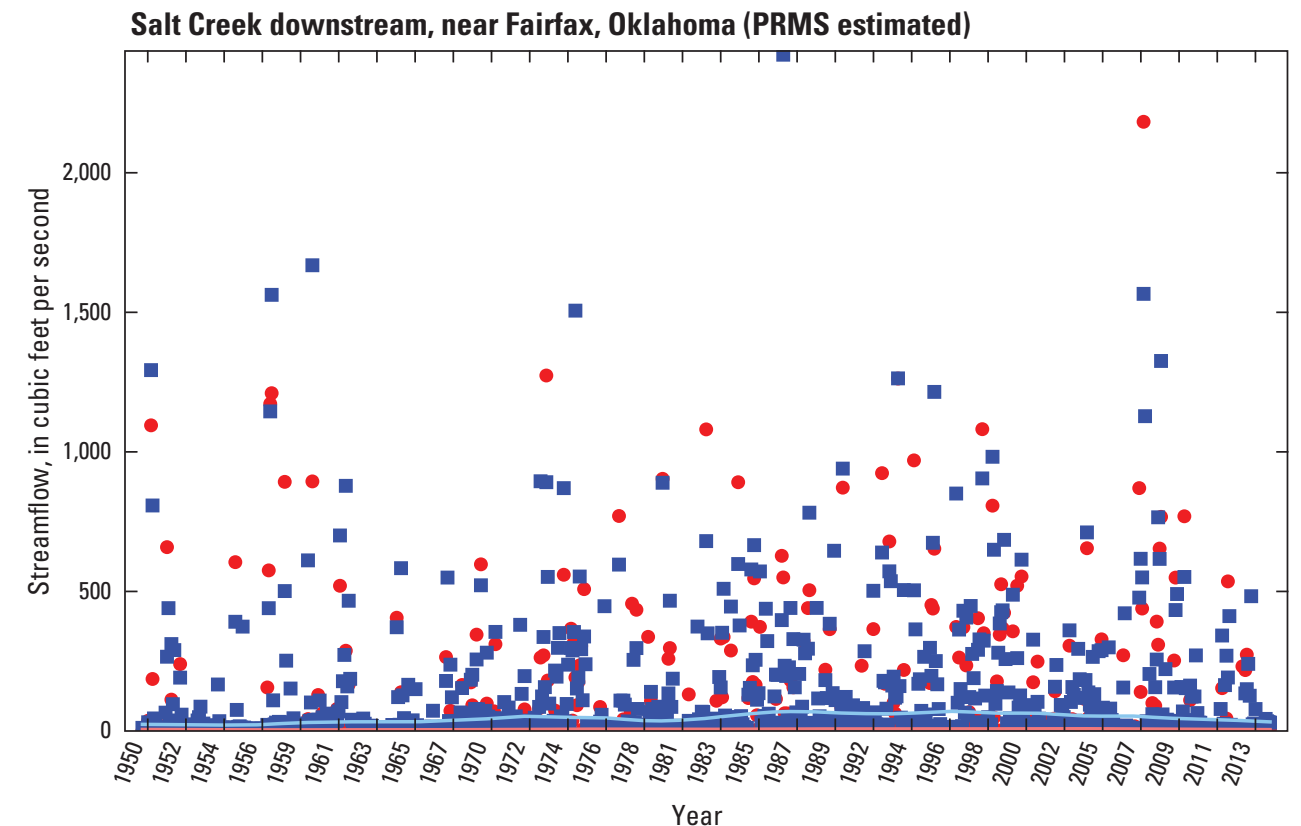

\section{EXPLANATION}

[PRMS, Precipitation Runoff Modeling System]

Lowess

— Simulated

- Measured

Streamflow

- Simulated

- Measured

Figure 1.13. Measured and simulated streamflows for Salt Creek downstream, near Fairfax, Oklahoma (Precipitation Runoff Modeling System estimated).

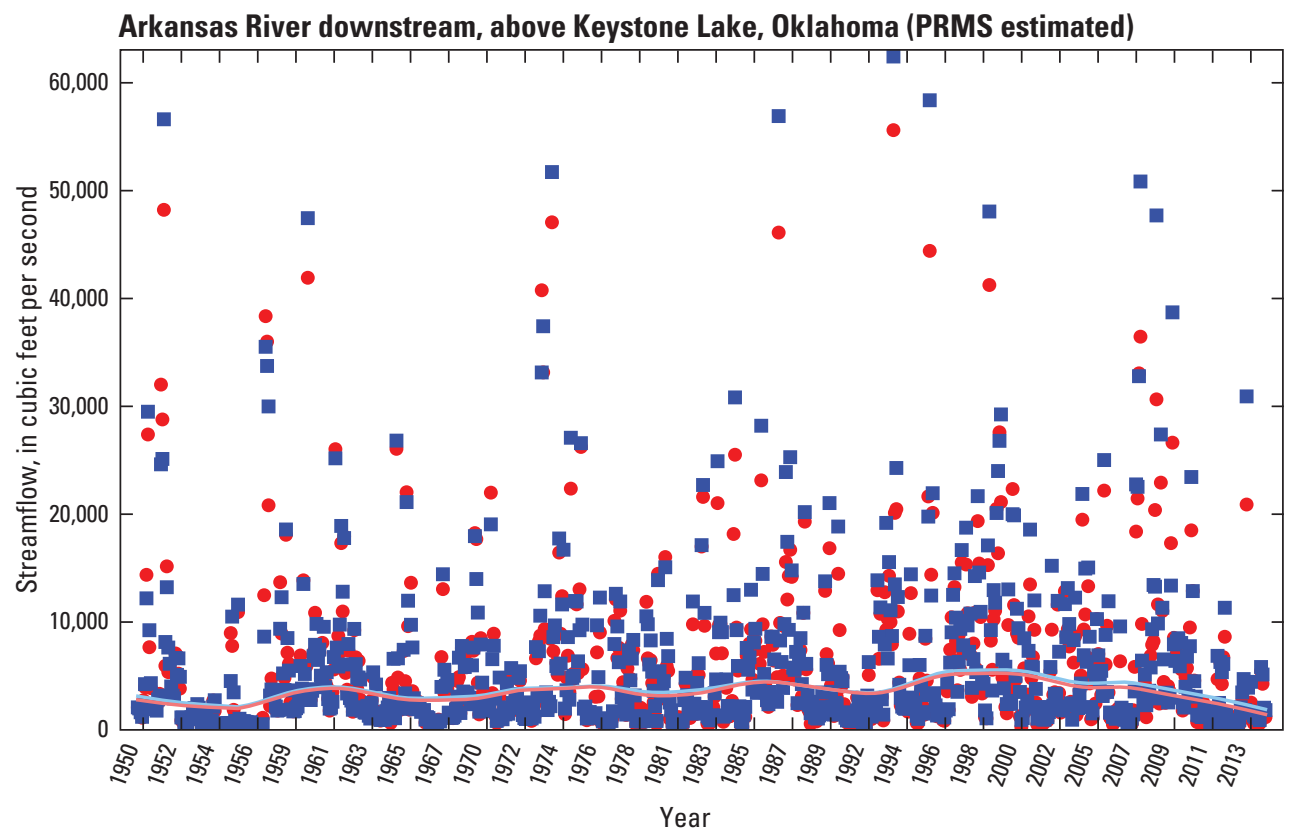

EXPLANATION

[PRMS, Precipitation Runoff Modeling System]

Lowess

— Simulated

- Measured

Streamflow

- Simulated

- Measured

Figure 1.14. Measured and simulated streamflows for Arkansas River downstream, above Keystone Lake, Oklahoma (Precipitation Runoff Modeling System estimated). 


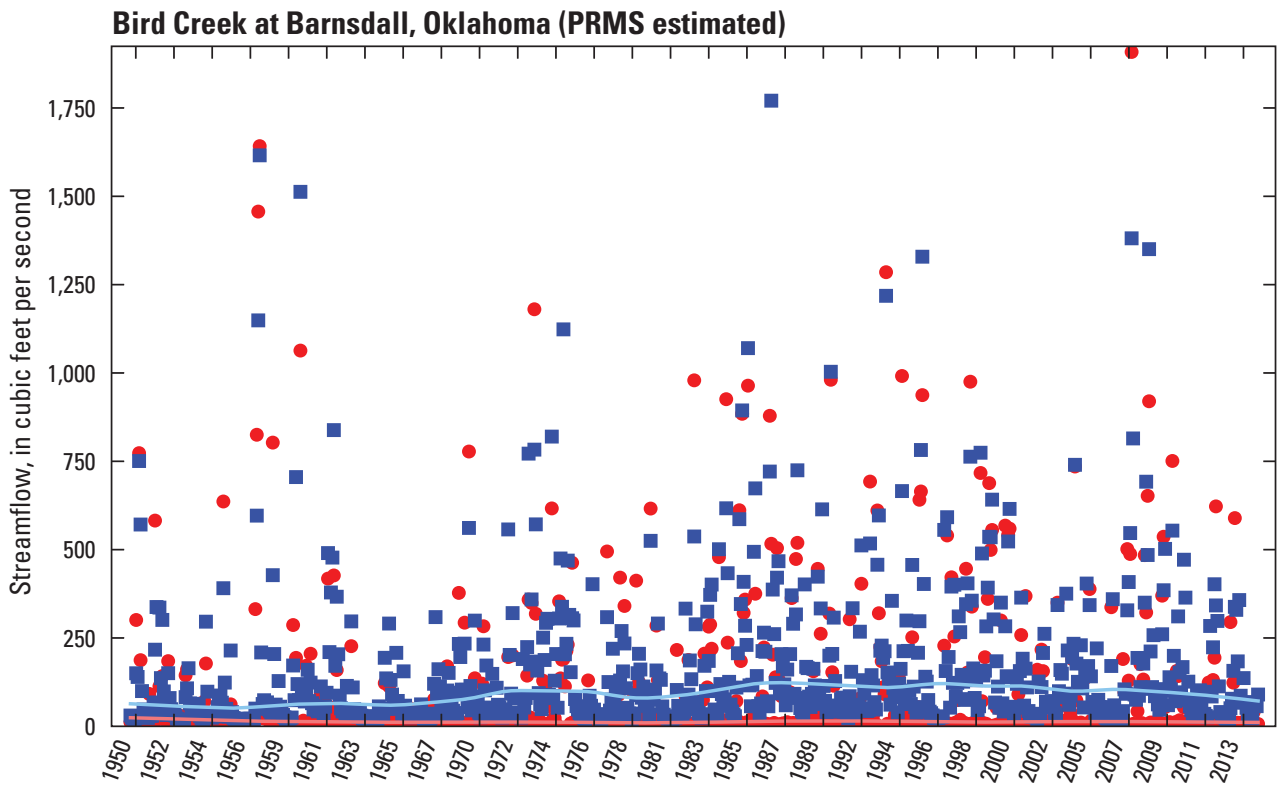

\section{EXPLANATION}

[PRMS, Precipitation Runoff Modeling System]

Lowess

- Simulated

- Measured

Streamflow

- Simulated

- Measured

Year

Figure 1.15. Measured and simulated streamflows for Bird Creek at Barnsdall, Oklahoma (Precipitation Runoff Modeling System estimated).

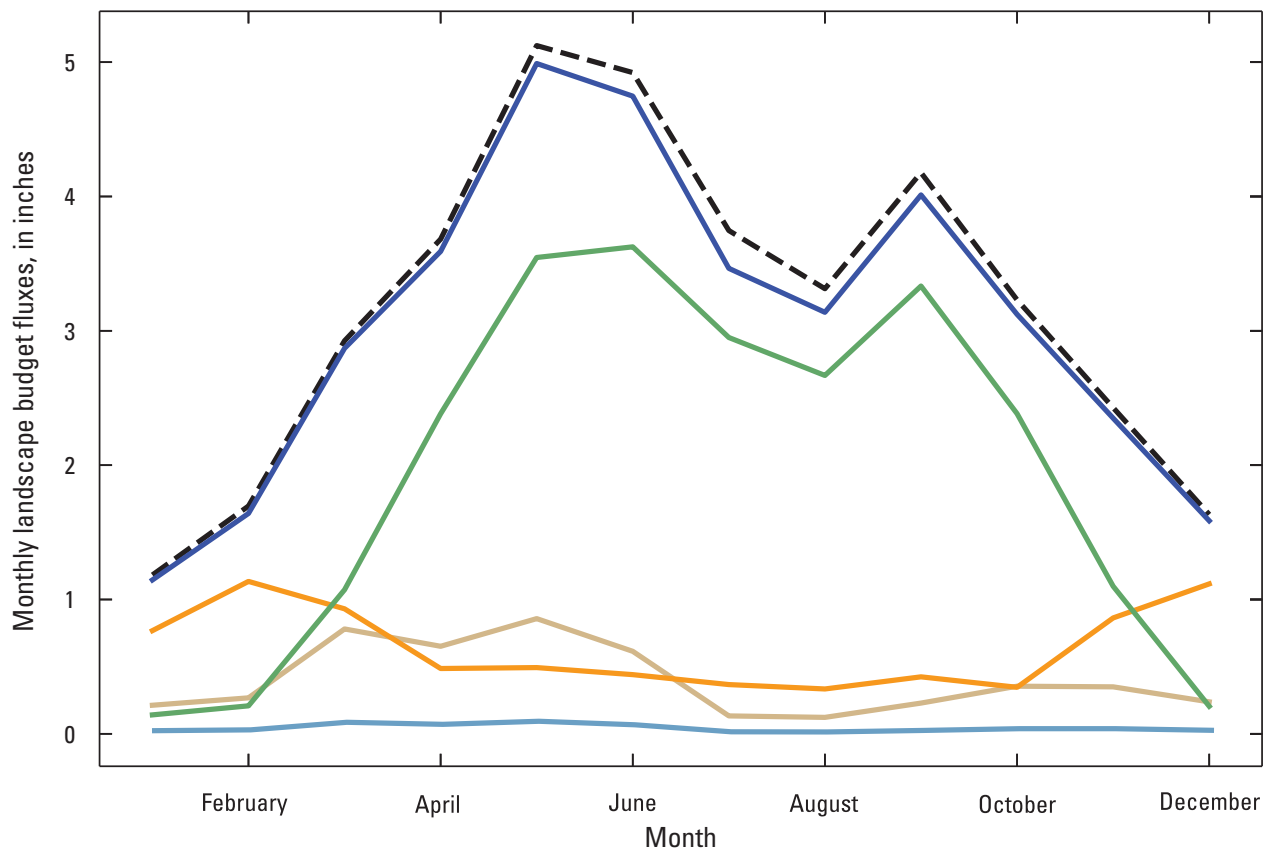

EXPLANATION

[net-p, difference between inflows and outflows of precipitation; net-wells, difference between inflows and outflows of applied irrigation water; net-ro, difference between inflows and outflows of runoff from precipitation; net-ep, difference between inflows and outflows of evaporation of precipitation; net-tp, difference between inflows and outflows of transpiration of precipitation; net- $d p$, difference between inflows and outflows of deep percolation from precipitation]

- - net-p plus net-wells

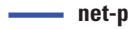

net-ro

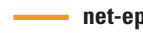

net-tp

— net-dp

Figure 1.16. Mean monthly landscape water budget component flux depths for the active model area, in inches. 


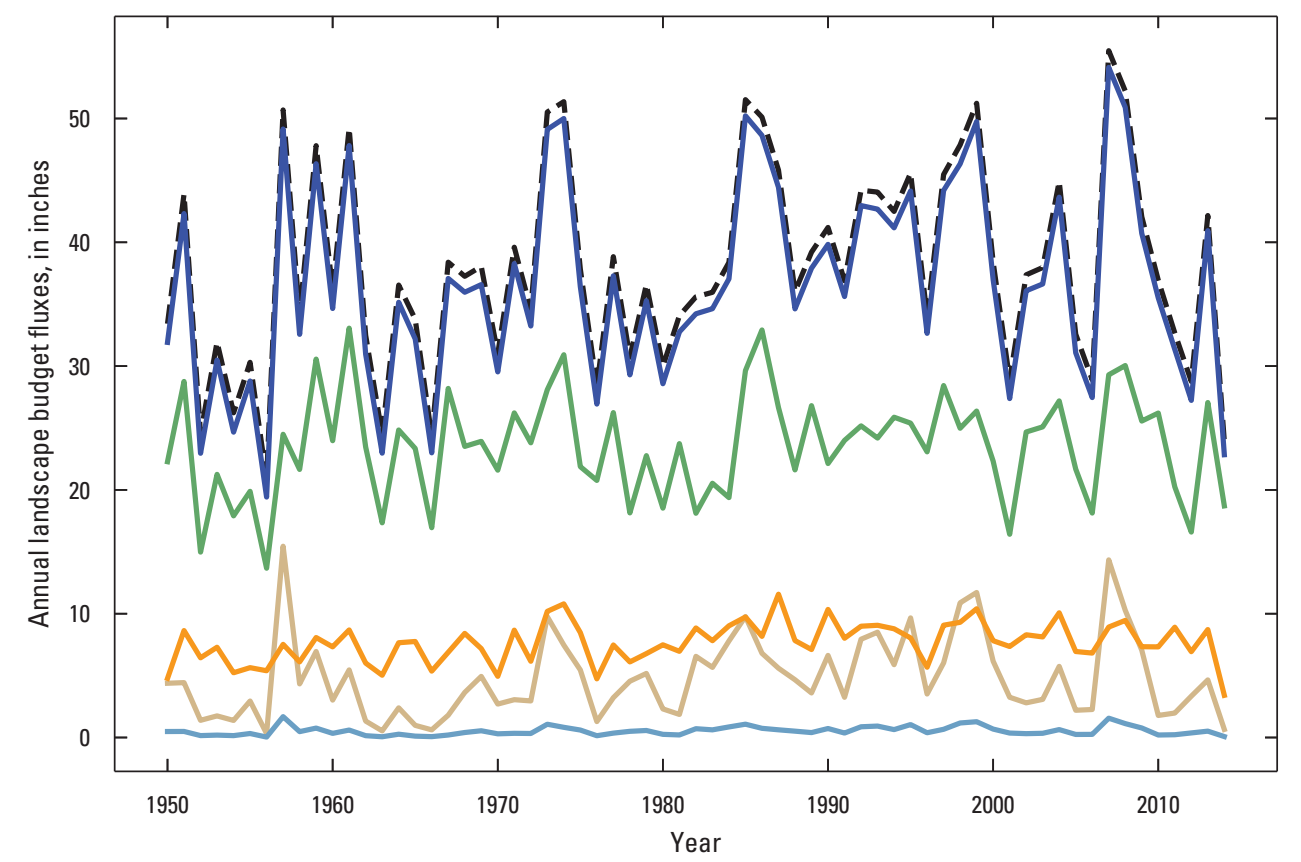

\section{EXPLANATION}

[net-p, difference between inflows and outflows of precipitation; net-wells, difference

between inflows and outflows of applied irrigation water; net-ro, difference between inflows and outflows of runoff from

precipitation; net-ep, difference between inflows and outflows of evaporation of precipitation; net-tp, difference between inflows and outflows of transpiration of precipitation; net- $d p$, difference between inflows and outflows of deep percolation from precipitation]

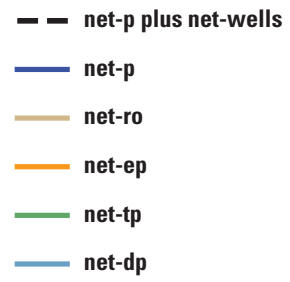

Figure 1.17. Mean annual landscape water budget component flux depths for the active model area, in inches. 
For more information about this publication, contact: Director, USGS Nebraska Water Science Center 5231 South 19th Street

Lincoln, NE 68512

402-328-4100

For additional information, visit: https://www.usgs.gov/centers/ne-water

Publishing support provided by the Pembroke and Rolla Publishing Service Centers 


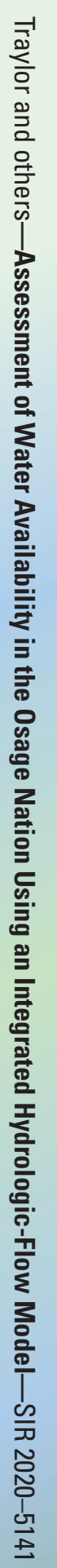

